\title{
PETROLOGY OF THE LAVAS OF GRANDE COMORE
}

by

DAVID F. STRONG, B.SC., M.So.

Thesis presented for the Degree of Doctor of Philosophy of the University of Edinburgh in the Faculty of Selence. 


\section{ABSTRACT}

The Comores archipelago consists of four volcanic islands situated on a linear rise across the northern entrance to the Mozambique Channel. These islands are, from east to west, Mayotte, Anjouan, Moheli, and Grande Comore. There are geomorphological indications that volcanism migrated westward, from deeply dissected and submerged Mayotte to the active Kartala volcano on Grande Comore. The volcanic rocks on all the islands appear to consist of silica-undersaturated basalts and thelr derivatives.

Grande Comore comprises two shield volcanoes, La Grille in the north and Kartala in the south. There is a complex sulte of collapse calderas at the summit of Kartala, marking the centre of historic volcanic activity in the archipelago. Each volcano is elongated, which, along with the abundant allgned and corlescing pyroclastic cones, reflects the importance of fissure eruptions in their development.

The lavas of Kartala are primarily alkali basalts, with abundant ankaramitic and oceanitic varieties, containing an average of 3.7 wt \% normative nepheline. From a detalled evaluation of the chemistry and petrography of these lavas it is postulated that they represent a series resulting from low-pressure fractional erystallization of alkali basalt magma. The magmes can be explained as resulting from more than $10 \%$ partial melting of garnet lherzolite upper mantle at pressures around $30 \mathrm{~kb}$, with some high-pressure (> $25 \mathrm{~kb}$ ) fractionation of harzburgite, garnet harzburgite, and either garnet wehrlite or eclogite, followed by subsequent polybaric fractionation of olivine 
11

\pm clinopyroxene during ascent.

The lavas of La Grille volcano are more undersaturated in silica than those of Karbala, containing an average of 11.5 wt \% normative nepheline, and many containing normative leucite. They also have higher average concentrations of $\mathrm{Ba}, \mathrm{Sr}, \mathrm{Rb}, \mathrm{CaO}, \mathrm{MgO}$, $\mathrm{P}_{2} \mathrm{O}_{5}$, and $\mathrm{MnO}$ than Kartala lavas. They have been classified in the present study as a basanitic series, and contain only olivine as an important phenocryst phase. The lack of any systematic relation between chemical and mineralogical composition precludes the possibility of their having a similar petrogenetic development to the Karbala lavas. They are explicable as originating from less than $10 \%$ partial melting of garnet lherzolite upper mantle, with substantial high-pressure fractionation of garret wehrlite or eclogite. Interruption of this high-pressure fractionation at different stages produced one trend of chemical variation, on which was superimposed a second trend resulting from polybaric fractionaction of Iherzolite, wehrlite and dunite, now found as ultramafic inclusions in the lavas. 
1. GENERAL INTRODUCTION

1.1. THE COMORES ARCHIPELAGO

1.1.1. Introduction 1

1.1.2. Mayotte 4

1.1.3. Anjouan 5

1.1.4. Moheli 7

1.1.5. Grande Comore 8

1.1.6. Relative volumes of each volcano 9

1.1.7. Tectonic setting 11

1.1.8. Summary 14

1.2. GENBRAL REVIEW OF ALKALINE IGNBOUS ACTIVITY 15

1.2.1. Introduction 15

1.2.2. Oceanic occurrences 15

1.2.3. Continental occurrences $\quad 17$

$\begin{array}{ll}1.2 .4 . & 19\end{array}$

1.3. THE PRESENT STUDY 20

2. GEOLOGY OF GRANDE COMORE

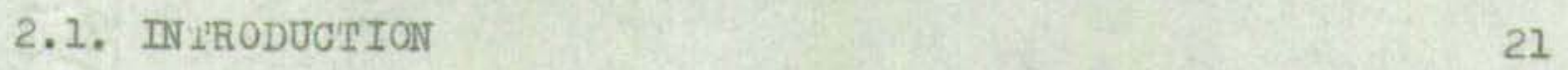

2.2. TOPOGRAPHIC UNITS OF GRANDE COMORE 21

2.2.1. Introduction 21

2.2.2. Massif de la Grille 22

2.2.3. Diboini Plateau 22

2.2.4. Massif de la Kartala 22

2.2.5. The Badjini Peninsula $\quad 25$

2.3. GEOLOGICAL MAP OF GRANDE COMORE 26

2.4. LAVA FLOWS 26

2.4.1. Sites of eruption 26

2.4.2. Dimensions of flows 28

2.4.3. Structures of flows 28 
2.6. PYROCLASTIC CONES

2.6.1. Introduction

33

2.6.2. Ginder cones

33

2.6.3. Tuff cones

2.7. THE KARTALA CALDERA.

2.7.1. Description of the caldera

36

2.7.2. Formation of the caldera

2.8. BROSIONAL FEATURES

2.8.1. River erosion

2.8.2. Marine erosion

2.8.3. Reers

44

2.9. SUMMARY

\section{PETROGRAPHY OF THE LAVAS}

3.1. INTRODUCTION

3.2. LAVAS

3.2.1. Classification of the lavas

46

3.2.2. Petrographic contrasts between Kartala and La Grille lavas

3.2.3. Badjini lavas

3. 3. OTHER ROCKS OF GRANDE COMORE

3.3.1. Pyroclastic rooks

3.3.2. Intrusive rocks

3.3.3. Ultramafic inclusions

55

3.3.4. Sandstone inclusions

56

3.4. SUMMARY 


$$
\text { 4. MINERALOGY }
$$

4.1. MINERALOGY OF THE KARTALA LAVAS

4.1.1. Introduction

4.1.2. 011vine

58

4.1.3. Clinopyroxene

4.1.4. Plagioclase

66

4.1.5. Other minerals

4.2. MINERALOGY OF THE LA GRILLE LAVAS

4.2.1. 01ivine phenocrysts

4.2.2. alinopyroxene phenocrysts

71

4.2.3. Groundmass minerals

4.3. SUMMARY

74

\section{PETROGEMMISTRY}

5.1. INTRODUCTION

5.2. MAJOR ELEMENT CHEMISTRY OF THE LAVAS

$5 \cdot 2 \cdot 2$. His tograms

5.2.3. Variation diagrams

5.3. C.I.P.W. NORMS OF LAVAS

5.4. TRACE ELFMEINT CHEMISTRY OF THE LAVAS

5.4.1. Introduction

5.4.2. Histograms

91

5.4.3. Variation diagrams

5.5. RARE-EARTH ELEMENTS

5.6. CHEMISTRY OF OTHER ANALYSED ROCKS

5.6 .2 . Intrusive rocks

96

5.6.3. Pyroclastic rocks

96

5.6.4. Feldspar-phyric rocks

99 
5.7. SIATISTICAL ANALYSIS OF LAVA CHEMISTRY 100 5.7.1. Introduction 100 5.7.2. Discriminant funotion analysis $\quad 100$

5.8. SUMMARY

6. DIFESRERITIATION OF THE LAVAS

6.1. INTRODUCTION

6.2. DIFFERENTIATION OF THE KARTALA LAVAS

6.3. DIF FERENTIATION OF THE LA GRILLE LAVAS

7. FORMATION OF THE LAVAS

7.1. INTRODUCTION

7.2. UPPER MANTLE COMPOSITION

7.2.1. Major elements

7.2.2. Trace elements

7.3. ENRICHMENT FACTORS

7.4. ORIGIN OF THE KARTALA LAVAS 126

7.4.1. Introduction $\quad 126$

7.4.2. Generation of Kartala lavas 127

7.5. ORIGIN OF THE LA GRILLE LAVAS 132

7.5.1. Introduction 132

7.5.2. Generation of La Grille lavas 133

7.6. PETROGFNETIC SUMMARY 138

7.6.1. Kartala lavas 138

7.6.2. La Grille lavas 139

ACKAN OWLEDGEMEENTS

BIBLTOGRAPHY $\quad 143$

APPENDICES

PLATES 1 TO 20. 


\section{FIGURES}

No. Title

1. Regional setting of the Comores archipelago

$\underline{P a g e}$

2. Local setting of the Comores archipelago

3. Topographic map of Grande Comore

4. Profiles of Grande Comore

5. Goological map of Grande Comore 27

6. Typical profiles of clnder and tuff cones 34

7. a. Geological map of Kartala caldera 37

b. Schematic outline of the separate collapse calderas and graben-type fractures which combined to produce the Kartala caldera

8. Projection of lava norms from plagioclase onto the plane nepheline-diopside-forsterite

9. Histograms of modal phenocryst contents in lavas of La Grille and Kartala

10. Histograms of modal vesiole contents in lavas of La Grille and Kartala

54

11. Plot of Ca:Mg:Fe ratios of Karcala ellnopyroxenes 65

12. Augite-olivine tie-lines in Ca:Mg:Fe diagram 67

13. Histograms of major element distributions in La Grille and Kartala lavas

14. Varlation diegrams for major elements in the Kartala lavas

15. Varlation diagrams for major elements in the La Grille lavas

16. $\mathrm{Na}_{2} \mathrm{O}+\mathrm{K}_{2} \mathrm{O}$ versus $\mathrm{SiO}_{2}$ in Kartala and La Grille lavas

17. "F.M.A." diagram for Kartala and La Grille lavas 85

18. Normative feldspar compositions in the system albite-anopthite-orthoclase 
$\underline{P a g e}$

19. Projections of norms of Kartala lavas in the "simple basalt tetrahedron".

20. Projections of norms of La Grille lavas in the

"simple basalt teirahedron".

21. Histograms of trace element distributions in La Grille and Kartala lavas

22. Varlation diagrams for trace elements in Kartala lavas

23. Variation diagrams for trace elements in La Grille lavas

24. K vs. Rb in the Lavas of Grande Comore 97

25. Rare-earth element distribution patterns 98

26. Discriminant functions calculated from trace element concentrations

102

27. Discriminant functions calculated from major element concentrations

28. Histograms of phenocryst distributions as a function of $\mathrm{MgO}$ content in La Grille and

Kartala lavas

29. Volume percent phenocrysts versus normative olivine in La Grille and Kartala lavas.

30. Projections of Kartala lava compositions in the C.M.A.S. pseudo-quaternary system

31. $\mathrm{SiO}_{2}$ versus $\mathrm{MgO}$ for La Grille lavas recalculated as phenocryst-Iree

32. Projections of the La Grille lava compositions in the C.M.A.S. system

33. C.M.A.S. projections of the Kartala and La Grille lave compositions, schematically reproduced from F1gs. 30 and 32

34. Concentrations of some minor and trace elements vs. $\mathrm{Ba}$ in Kartala and La Grille lavas

35. Schematio representation in the C.M.A.S. system of the postulated sequence of processes involved in the development of Kartals and La Grille lavas 


\section{TABLES}

No.

1. Estimated volumes of each volcano

2. Historic volcanic activity on Grande Comore

3. Classifleation of the lavas

4. Chemical composition of Kartala olivines

5. Composition of Kartala olivines

6. X-ray Pluorescence analysis of Kartala clinopyroxenes

7. Electron microprobe analysis of Kartala augites

8. Chemical composition of Kartala plagioclases

9. Anorthite contents of Kartala plagioclases

10. Forsterite contents of La Grille olivines

11. Chemical composition of clinopyroxene from Iherzolite

12. Chemical analyses of lavas from Grande Comore given by Lacroix

13. Relative silica-undersaturation in the lavas of Grande comore, as indicated by normative mineralogy

14. Concentrations of rare-earth elements in samples 1 and 9

15. Average $\mathrm{Rb} / \mathrm{Sr}$ and $\mathrm{K} / \mathrm{Sr}$ in Kartala and La Grille lavas

16. Representative compositions of Kartala and La Grille lavas

17. Hypothetioal upper mantle garnet peridotite composition

18. Enrichment of minor and trace elements relative to the postulated upper mantle concentrations 


\section{PLATES}

1. Typioal coastal exposure, southeast Grande Comore.

2. Columnar-jointed lavas exposed in walls of Chagnoumeni pit crater.

3. Plagioclase-phyric flow, Foumboudzivouni.

4. Aerial view of aligned cinder cones, Massif de la Grille.

5. Haboho oinder cone.

6. Sima cinder cone.

7. Goudjoulachamle einder cone.

8. Typical cinder cone with breached walls.

9. N'Gouni tufe $\operatorname{con} \theta$.

10. Panoramic view of the Kartala caldera.

11. Vertical basaltic dyke in caldera wall.

12. Photomicrograph of typical alkali basalt.

13. Photomicrograph of typioal alkali olivine basalt.

14. Photomicrograph of typical oceanite.

15. Photomicrograph of typical ankaramite.

16. Photomicrograph of typical feldspar-phyric basalt.

17. Photomicrograph of typical basanite.

18. Photomicrograph of typical nepheline basalt.

19. Photomlerograph of orthopyroxene xenocrysts.

20. Photomicrograph of quartz xenoorysts. 


\section{GENERAL INTRODUCTION}

1.1 THE COMORES ARCHIPELAGO

1.1.1. Introduction

The Comores Archipelago is situated at the northern entrance to the Mozambique Channel, between $10^{\circ} 21^{\prime}$ and $13^{\circ} 03^{\prime}$ south and $43^{\circ} 15^{\circ}$ and $45^{\circ} 20^{\prime}$ east (Fig. 1). It comprises four principal islands distributed over a distance of $275 \mathrm{~km}$ along a NNW-trending submarine $\mathrm{N}$ plateau which rises from depths in excess of $3 \mathrm{~km}$. These islands are, from east to west, Mayotte, Anjouan, Mohell, and Grande Comore. Two atoll groups, Banc du Geyser and Isles Glorieuses, are found ENE of Mayotte, offset from the Inear trend of the Comores Archipelago (Fig. 1). These may represent the earliest manifestations of Comores voleanism.

The Archipelago has a tropical climate, with abundant rainfall and high temperatures, and trade winds (or monsoon) blowing more or less continuously from southerly directions. This produces a deep lateritic soll and lush vegetation which, particularly in the older islands, makes geological investigation difficult.

The essentially volcanic nature of the islands was discussed by Voeltzkow (1906) and later by Lacroix (1922), who provided the first petrographic descriptions and chemical analyses of the rocks. However, the first detalled geological study was made by De saint Ours (1960), who was particularly interested in the geomorphology and economic geology of the islands.

The present study commenoed in 1967 when geologists from Edinburgh and Manchester Unlversities (Esson, Flower, Upton and 


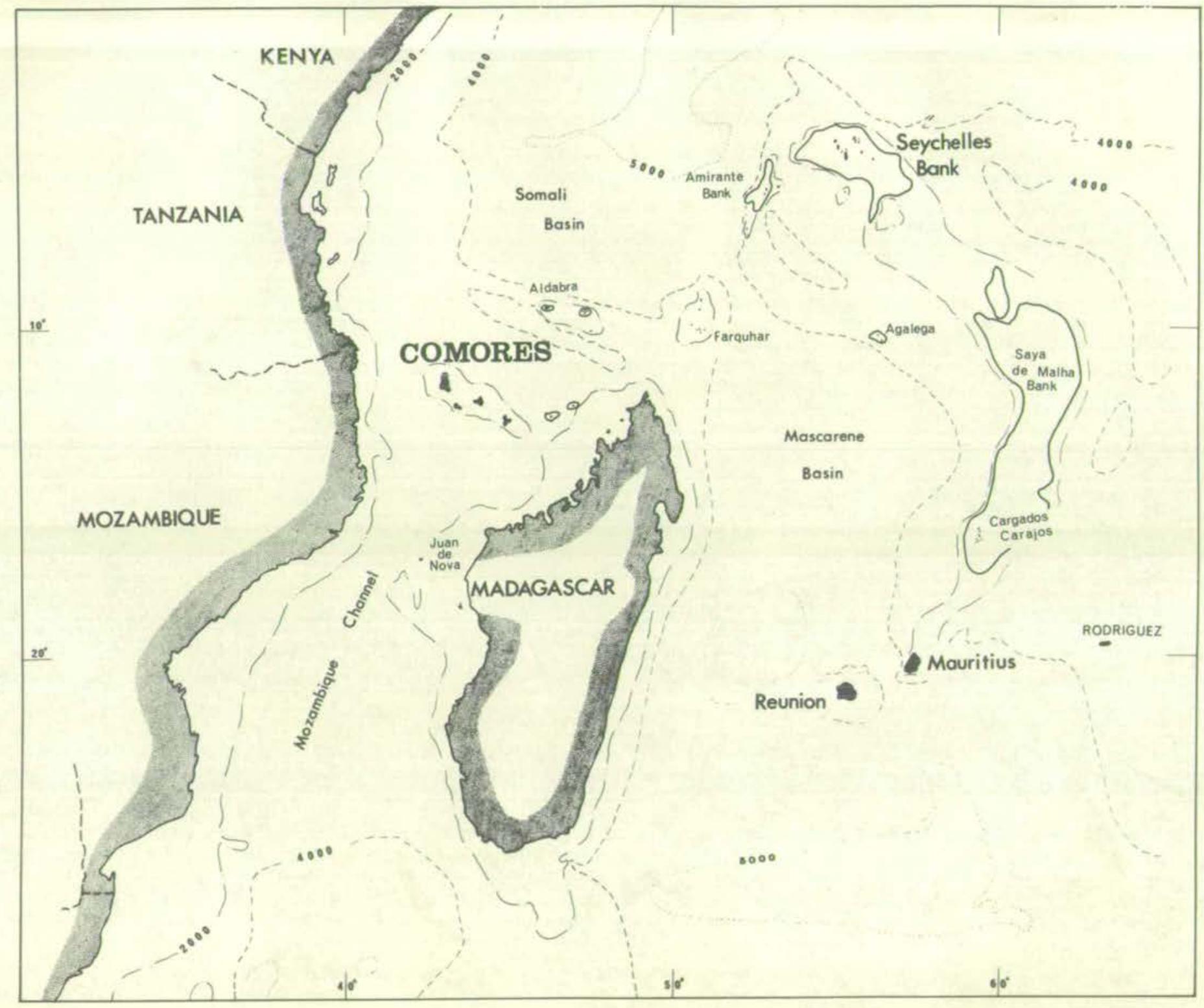


Fig. 2 .

Local setting of the Comores arohipelago.

Submarine contours, given in metres, were drawn from data points on the $1 / 500,000$ scale map of the archipelago published by the Institut Geographique National of France, 1964. Contours on the islands at intervals of 500 metres. 


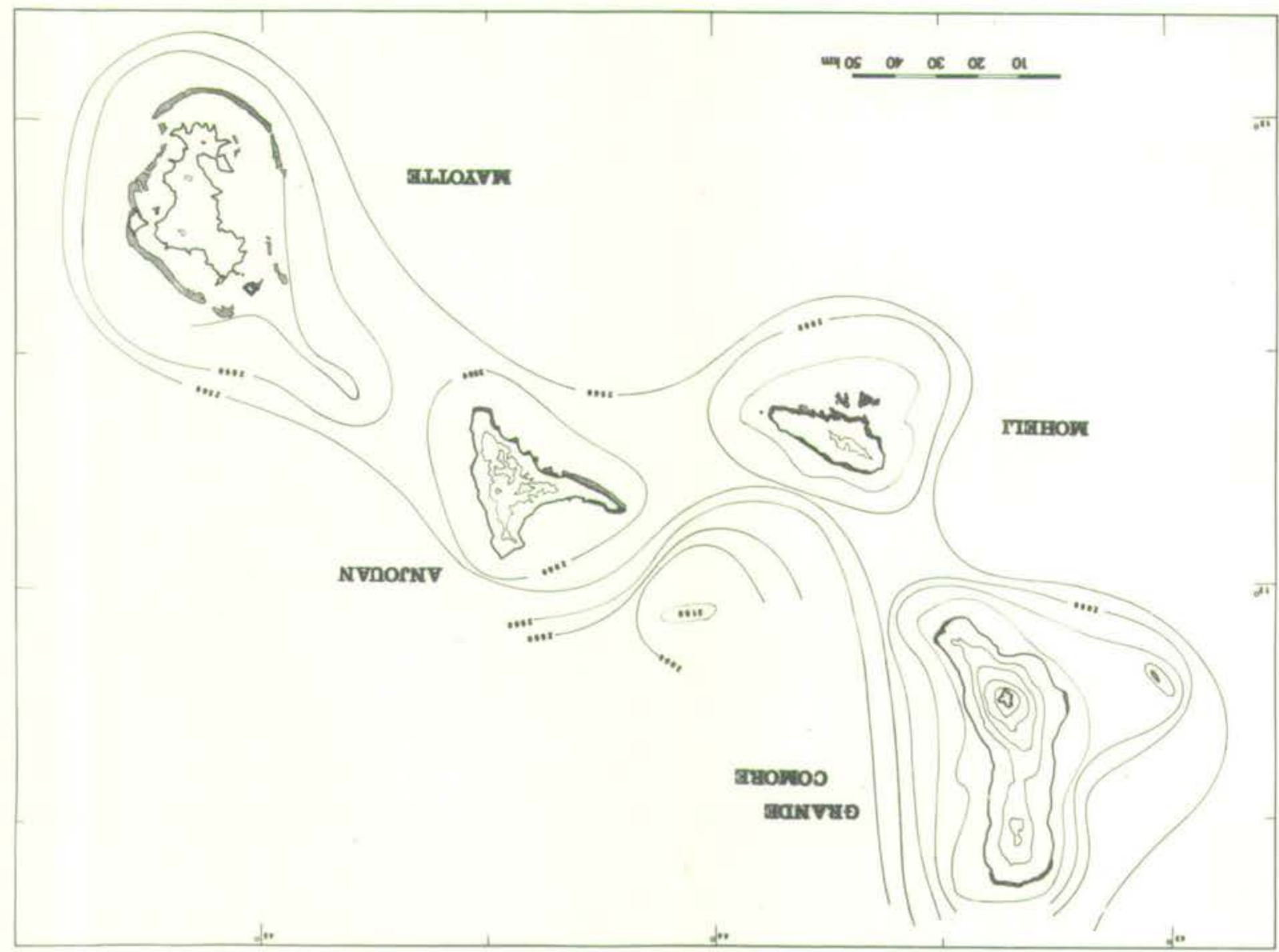


Wedsworth) spent several weeks on reconnaisance fleld-work in preparation for detailed studies. Flower and the present writer returned to the islands in 1968, and further fleld-work was carried out on Grande Comore, Anjouan, and Moheli. The whole study forms part of a more general research programme on the volcanic islands of the western Indian Ocean.

The following general account is based primarily on the work of De Saint Ours (1960) and a preliminary report by the present investigators (Esson, et al, in press).

\subsubsection{Mayotte}

Mayotte, $320 \mathrm{~km}$ from Madagascar and most easterly of the Comores islands (Fig. 2), is the most low-lying of the group, with maximum altitude of only 660 metres. It has undergone deep submergence and dissection, resulting in a deeply embayed coastline and rugged topography. Nevertheless, it retains a strong pattern of $\mathrm{NW}^{-}$and $\mathrm{N}-$ trending lineations in the form of mountain ridges, cosst lines, submarine escarpments, and reef margins, which is probably controlled by a fundamental pattern of rifts and faults in these two principal directions.

The 1sland is surrounded by fringing reefs, and an almost continuous barrier reef. The barrier reef has a smooth elliptical form which stands in marked contrast to the islands jagged coastline. This elliptical form may represent the periphery of an ancient Mayotte volcano. If this is the case, it implies that the ancient volcano was some $55 \mathrm{~km}$ long and $35 \mathrm{~km}$ wide, and assuming slopes of $8^{\circ}$, probably more than $3 \mathrm{~km}$ high. The reefs and lagoon were studied by Guilcher (1965), who explained submerged river valleys and karst topography as 
resulting from subaerial erosion during a Plelstocene period of low sea level.

The oldest rooks of Mayotte consist of deeply eroded basalts, which form small hills and low-lying plateaux with a maximum relief of 450 metres. De Saint Ours, by comparison of geomorphology with Mt. Ambre in Madagascar, considered it possible that these basalts are Turonian-Cenonian (Upper Cretaceous) in age. Phonolitic plugs form resistant masses up to 660 metres high, and appear to make up much of the central ridge of the island. Resistant ribs running down to the cosst from this central ridge consist of flows of trachybasalt, basanite, nephelinite, and phonolite. The only constructional volcanic features remeining are the deeply dissected pyroclastic craters Karani and Kaweni, in the northeast part of the island. An extensive blanket of lateritic clay covers the northern inland regions of the island. Xenoliths of hornblendite, anorthosite, peridotite, gabbro, and syenite have been found by Esson in the lavas and tuffs. Although the Mayotte volcano shows every sign of extinction and advanced decay, the eruption of three tuff cones through the reef at Pamanzi show that there has been a rejuvenation of activity in the recent past.

1.1.3. An Jouan

Anjouan, $80 \mathrm{~km}$ northwest of Mayotte (Fig. 2), is dominated by a central peak, N'Tingui, which rises to a height of 1,595 metres. According to De saint Ours (1960, p. 226), the ancient N'Tingui volcano, probably reaching heights of $3 \mathrm{~km}$, is now eroded into deep gorges and cirques comparable to the classical amphitheatre-headed 
valleys of the Hawailan islands (cf. Stearns and Vaksvik, 1935). The rocks of the central N'Tingul massif are chlefly alkali basalts of ankaramitic type. These were assigned to a Mlocene phase of eruption by De Saint Ours, which he termed the "phase Inferieur".

According to De Saint Ours, the three main peninsulas of Anjouan were formed by fissure eruptions during lower to middle Quaternary times, and he referred to these as the "phase intermediare". Lavas of this phase also occupy the gorges and river valleys eroded Into the N'Tingui massif. These younger lavas are more undersaturated in sillca than the older ones, and include basanites, trachybasalts, trachytes, and phonolites. Over 50 tuff cones are present on Anjouan and, despite much variability in the state of dissection (and therefore age), most are assigned by De Saint Ours to a period of volcanism younger than the "phase intermediare". A body of quartz gabbro, about 250 metres in diameter, intrudes the lavas of the "phase inferieur" in the upper reaches of the Clrque de Bambao. Xenoliths of gabbroic and ultramafle rocks (sometimes layered) are cormon in the more basic lavas, and xenoliths of syenite have been recovered from the phonolitic flows. Fragments of quartzitic and arkosic sandstone have been found in the younger basaltic lavas, and arkosic sandstone crops out over an area of 250 square metres in the Cirque de Bambao. The significance of these sandstones has been discussed by Flower and strong (1969).

The southwest and east coasts of Anjouan are straight and regular, parallel to the fissure system inferred from Mayotte lineaments, and 
the alignment of its southwest coast with the straight north coast of Mayotte is partioularly striking (Fig. 2). The distinctly concave northern coast does not fit this regional pattern of fissures, and may be the result of slumping of the volcanic pile into the deep waters (greater than 3000 metres) just northwest of Anjouan (Fig. 2). Anjouan is bordered by fringing reefs, but barrier reefs are only in an incipient state of development, an indication of the youthrulness of this island relative to Mayotte.

1.1.4. Moheli

Moheli, the smallest of the four main islands, lies $45 \mathrm{~km}$ to the southwest of Anjouan (Fig. 2). The island can be divided into two distinct topographic regions, viz. a relatively low-lying (less than 400 metres) eastern plateau, and a more mountainous western half. The latter is dominated by a Jagged median ridge which rises to a maximum height of 790 metres. A group of small elongate 1slets off the south coast appear to radiate from this peak.

De Saint Ours (1960) recognized the same two phases of volcanism on Moheli as he did for Anjouan. The "phase inferieur" supposedly makes up the western mountainous area, which consists of basanites, nephelinites, ankaramites, and minor phonolitic rooks. The "phase intermediare" in the eastern half consists of more olivine-rich varieties of basaltic rooks. Some doubt is thrown on these relative ages, however, by an abundance of youthful flows in the western part and a deep soll cover in the eastern part of the 1sland. These suggest that the relative ages of each area are in fact in the reverse order of that pestulated by De Salnt Ours, 1. $\theta$. 
with the older part being in the east. Recent tuff cones are seen in both areas, and their respective ages do not appear to have any geographic correlation.

Samples of presumed intrusive rocks are found as boulders in most riverbeds of Mohell. These consist of gabbros, syenites, and 1jolites; none of these has been seen in situ. Ultramafic inclusions are found in basaltic lavas, both in flows and river boulders. One sandstone inclusion, $50 \mathrm{~cm}$ in diameter, was found in a younger basaltic lava flow.

Although the present elongate form of the main island is probably a reflection of repeated eruptions along WW fissures, the clrcular submarine contours (Fig. 2) suggest the former presence of a large central volcano. In this light, the southern islets may be explained as younger lavas which occupled river valleys eroded into this volcano, and which were preserved as positive rellef features after further erosion of the intervening spurs of older basalt.

Moheli is completely surrounded by fringing reefs, but no barrier reef, in contrast to Mayotte and Anjouan.

1.1.5. Grande Comore

As Grande Comore is described in detail in the following chapter, only very general information will be given here. It is the most westerly of the four islands (Fig. 2), only $280 \mathrm{~km}$ from Cape Delgado in Mozambique. It is the largest island in the group, and is made up of two volcanic massifs.

The northern volcano, La Grille, has the form of a gently domical 
shield which reaches a maximum helght of 1087 metres, and is covered by more than 120 tuff cones. Its lavas are chiefly olivine-phyric basanites, In some cases containing ultramafic and, more rarely, gabbroic inclusions. Scarce arkosic sandstone inclusions are also found In La Grille lavas, and are similar to those described for Anjouan and Mohel1.

Kartala, the southern volcano, is a steep-sided shield volcano, 2361 metres high, and crowned by a large dome and a complex suite of collapse calderas. The Kartala lavas are all alkall basalts, with highly variable proportions of olivine and augite phenocrysts, and rarer plagioclase phenocrysts.

The smooth topography and coastline, and the scarcity of reef development, indioate the jouthfulness of Grande Comore relative to the other three islands. Kartala is the only active volcano of the group, although La Grille has also been active in historle times. 1.1.6. Relative volumes of each volcano

As indicated above, each of the islands has undergone differing degrees of erosion, with the result that their present sizes are not representative of the volumes of the lava originally exupted. There is no exact way of obtaining these original volumes, but some approxImate estimates can be made.

Although the lavas from each volcanic center probably overlap at depth, the individual domes appear to separate at depths around $2 \mathrm{~km}$ (Fig. 2), With this in mind, the volume of each voloano above this level can be arbitrarily estimated, although much of the total volcanic material (1.e. below $2 \mathrm{~km}$ ) will not be included. These 
volumes are given in Table 1 , as calculated by assuming that each volcano was conical, with $1 \mathrm{ts}$ base at the $-2 \mathrm{~km}$ contour, and a mean radius calculated at this contour. For the eroded eastern islands, the height of each cone was calculated by assuming original slopes of $9^{\circ}$, slightly greater than those of La Grille. For the "Grande Comore" calculation, Kartala, La Grille, and the Vailheu reef were included as one volcano, and an altitude was assumed intermediate between Kartala and La Grille.

It should be emphasized from Table I that any subsequent discussion of these voloanoes will be concemed only with the subaerial parts, certainly less than $7 \%$, and probably less than $3 \%$ of the total volume of exupted magma.

\section{Table 1}

Estimated volumes of each volcano

\begin{tabular}{|c|c|c|c|}
\hline Volcano & $\begin{array}{l}\text { Subaerial } \\
\text { Volume, } \mathrm{km}^{3} \\
\end{array}$ & $\begin{array}{l}\text { Total } \\
\text { Volume, } \mathrm{km}^{3} \\
\end{array}$ & $\begin{array}{l}\text { Subaerial as } \\
\text { Percentage of } \\
\text { Total Volume } \\
\end{array}$ \\
\hline Mayotte & 58 & 6,880 & $0.8 \%$ \\
\hline An jouan & 262 & 1,800 & $14 \cdot 6 \%$ \\
\hline Moheli & 41 & 2,300 & $0.02 \%$ \\
\hline $\begin{array}{l}\text { "Grande } \\
\text { Comore } e^{*}\end{array}$ & 749 & 4,220 & $17 \cdot 7 \%$ \\
\hline Kartala & 625 & $"$ & $14 \cdot 8 \%$ \\
\hline La Grille & 124 & $"$ & $2.9 \%$ \\
\hline
\end{tabular}

* "Grande Comore" estimate includes an allowance for the Vailheu reef. 


\subsubsection{Tectonic setting}

The scanty evidence bearing on the tectonics of the westem Indlan Ocean have been revlewed by Flower and Strong (1969), and the following summary is taken directly from this paper.

There are two essent1ally contradictory views on the tectonics of the westem Indian Ocean. Fisher et al. (1968), mainly on the basis of oceanographio studies, suggested that Madagascar was once twenty degrees north of its present position relative to Africa, and connected to the Seychelles Bank. These were then separated by the southward movement of Madagascar by left lateral faulting sometime between the Permian and Cretaceous periods, and the ocoan floor between Madagascar and the Seychelles was subsequently developed during cretaceous volcanism. The merits of this interpretation are that it agrees with an hypothesis of sea floor spreading from the Carlsberg Ridge, it can explain the pattem of magnetic anomalies and bottom topography in the area, and a north-northeast projection of the proposed fault coincides with the Owen Fracture Zone.

This southerly faulting mechanism does not, however, account for the present eastward position of the Saya de Malha mioro-continent, which Fisher et al. (1967) earlier proposed to extend from the Seychelles to Cargados Carajos. The northem coincidence of the proposed fault zone with the Owen Fracture should not be relied upon too heavily for several reasons; 1.e. correlation of the very old and seismically inactive southern fault with the presently seismically active Owen Fracture is hardly justifled, and the right lateral displacement on the Owen Fracture is opposite to that required. 
Perhaps the most serlous objection to their interpretation is that it requires the orust in the southern part of the Somali Basin to be basaltic. Although Fisher et al. (1968) interpret seismic data (Francis et al., 1966) as indicative of rocks "wholly volcanic except for an uppermost layer of sediments", Franc1s et al. (1966) find Karroo beds well out into the Somali Basin, and a layer with 5 Selsmic velocities of $2.5 \mathrm{~km} / \mathrm{sec}$ almost as far east as the Sejohelles (page 259, Fig. 19), which they correlate with African drill core data and explain as "probably consolidated sediments of Jurassic and Cretacoous age". Thus, any separation of Madagascar and the Seychelles would have occurred before the Jurassic, and the required basaltic material does not appear to be present to any large extent. An additional important criticism to the hypothesis of southward movement of Madagasar is that it conflicts with the tensional environment of the area, well established through studies of the African rift systems.

The second major interpretation of the tectonics is that put forth by Dixey (1956), who suggests that the Mozamblque Channel is geosynclinal in nature, having resulted from Karroo (late Carboniferous) and later subsidence along normal faults in a tensional environment. Dixey suggests that this geosyncline may extend over the full length of the east coast of Africa. By extrapolation of data from both sides of the channel he concludes that it contains about $8 \mathrm{~km}$ of Karroo sediments and $6 \mathrm{~km}$ of post-Karroo sediments, with Precambrian basement at a depth of about $14 \mathrm{~km}$. This conclusion is supported by Pepper and Everhart (1963) who, on the basis of seismio and drill core data, put the basement at a depth of $7.5 \mathrm{~km}$ near the southwest 
coast of Madagascar, and who also point out that granite on the island of Juan de Nova supports this conolusion. The sediment thicknesses postulated by Dixey (1956) are also in agreement with thicknesses for the Somali Basin given by Francis et al. (1966). The gravity data for the Mozambique Channel given by Talwanl (1962) may be interpreted as indicative of continental crust, overlain by the thick Karroo and Cretaceous lavas, and work of H.M.S. Owen in 1961-1962 Indicates that Madagascar is connected to Africa by continental orust (Holmes, 1965, p. 936). There is clearly much evidence in favour of Dixey's hypotheats.

If the Mozambique Channel is underlain by Precambrian basement, then Madagascar has probably never been in other than its present position relative to Africa; if the Channel contains only Karroo and post-Karroo sediments and lavas, then Madagascar may have moved eastward from Africa. Elther way, the evidence is conclusive that Madagascar did not move into its present position from the north. In the light of this disoussion it is clear that there is a need for direct evidence as to the nature of crust beneath the Mozambique Channel or the Somali Basin.

As shown in Fig. 1, the Comores Archipelago lies in a oritioal position between the Mozambique Channel and the Somali Basin. Vienne (1900) reported "grey-blue granite and quartz rocks" from southern Grande domore at Morotso, Roveni, and Chindini, but no source for these rooks was given. Lacroix (1922) gave detalled descriptions of metamorphic rocks found at Mutsamudu, Anjouan, and quartz monzonite inclusiong in the tuffs at Dzaoudz1. The orthogeneiss consists of almandine, biotite, mioroline, oligoclase, and 
quartz, and is common in Madagascar. He also describes amphibole granite, granodiorite rich in diopside, homblende and biotite, as well as quartz monzonite, anorthosite, olivine gabbro, and serpentinzed peridotite from the same locality. From these rooks Lacroix concluded that the islands were underlain by crystalline basement. De Saint Ours (1960), unable to find any such rocks, did not accept Lacroix's conclusions, and suggested that dredging of the submarine plateau might solve the problem. Whether or not these rocks were derived from underlying basement, the sandstone inclusions found by the present workers is unequivooal evidence that the islands are at least underlain by sedimentary rooks. In this light the Comores volcanoes cannot be described as truly oceanic, as they must have passed through some highly siliclo material.

\subsubsection{Summary}

1. The Comores islands are situated on a long linear rise and show geomorphological indication of a decrease in age westwards.

2. Two prinelpal regional flssure systems appear to have controlled the voloanlsm.

3. Inclusions of sandstone are found in lavas of three of the four islands, indicating the presence of underlying silicic material through which the lavas were erupted.

4. The dominant petrological association is alkall basalt, basanite, nephelinite, trachyte, and phonolite. 
1.2. GENERAL REVIEW OF ALKALINE IGNEOUS ACTIVITY

1.2.1. Introduation

If this study of the Comores islands is to be of more than just local significance, it must be related to other occurrences of similar rocks, very common in both oceanic and continental crustal environments. Unfortunately, the crustal structure in the comores area cannot, with any certainty, be described as truly continental nor oceanic. Consequently, both continental and oceanic occurrences, and the hypotheses surrounding them, may be relevant to the comores volcanoes. Accordingly, the following is a brief review of occumences from each environment that are petrologicaliy similar to the rocks of the Comores islands, and Grande Comore in partioular. 1.2.2. Oceanic occurrences

Although, unlike the Comores situation, alkalic lavas make up less than $3 \%$ of the volume of eny Hawalian volcano, the detail in which these islands have been studied makes them a reference point for any other voloanic studies. As a detailed discussion of the Hawallan alkaline lavas has recently been presented by Macdonald (1968a), only a brief summary of his views are given here.

The Hawalian alkali basalts were erupted after voluminous outpourings of tholeiltic lavas, and after long quiescence, these are followed by relatively small amounts of nepheline basalt and nepheline melilite basanite ("the nephelinic series"). According to Macdonald (1968a), the magmas produeing the alkalic and nephelinic suites were formed from an olivine tholelite magma by fractionation (of unspecified phases) at depths around $30 \mathrm{~km}$ and $50 \mathrm{~km}$ respectively, 
the olivine tholelite having formed by partial melting of the mantle at depths around $60 \mathrm{~km}$.

Differentiation of the alkalic magma (into an ankaramite alkalic olivine basalt - hawafite - mugearite - benmoreilte-soda trachyte suite) was thought to be brought about by fractional crystallization of augite, olivine, bytownite and nagnetite, in the approximate proportions $5: 2 \cdot 5: 2: 0 \cdot 5$. This accounts for the doninance of ankaramitic and absence of olivine-cumulitic rocks in the alkalic series, and in this respect they are clearly comparable to those of the Kartala volcano on Grande Comore. The nephelinic suite shows two fractionation trends. The first, (alkali olivine basalt - basanitoid basanite), results from fractionation of "pyroxene and olivine, and perhaps some feldspar". The second trend leads to the nephelinites and melilite nephelinites, and "may be largely controlled by the separation of orthopyroxene in place of olivine in a high pressure environment".

There are many oceanic volcanoes that appear to be more closely comparable to the comores than those of Hawali in that they show no visible indication of being underlain by tholeiltic basalts (e.g. Tutuilla, Macdonald, 1968b; Manu'a Island, Stice, 1\%68; Gough Island, LeNaitre, 1962; Tristan da Cunha, Baker, et al., 1964; St. Helena, Baker, 1969; Rodriguez, Upton, Wadsworth, and Newman, 1967; Cook Islands, Wood, 1969; Marshall, 1929; Clarion Island, Bryan, 1967; Truk Islands, Sterk and Hay, 1963; Ponape Island, Yagi, 1960; Mauritius, Walker and Nicolaysen, 1953; Tahiti, Williams, 1933; MoBirn 
Tahiti is particularly similar to the comores Islands in the range of rock types represented. Like Grande Comore, it is formed of two coalescing shield voloanoes, although it is more deeply dissected, and displays both plutonle and extrusive differentiates which are absent on Grande Comore, but present on Moheli, Anjouan, and Mayotte. Purthermore, both ankaramite and basanite are abundant on both volcanoes of Tahit1, whereas on Grande Comore they appear to be restricted to separate volcanoes. According to MoBirney and Aoki (1968), a Tahitian parental alkali basalt differentiated Into two divergent series, one trending towards trachyte and the other towards phonolite. They considered that fractionation of the observed mineral phases could not acount for these trends, and postulated that they resulted from fractionation at greater depth, where other phases would be stable.

1.2.3. Continential occurrences

As for oceanic volcanoes, chemical diversification of alkali olivine basalt in continental environments has most commonly been explained by some process involving crystal fractionation. One well-known example of this is the Eastern Otago province of New Zealand, recently reviewed by coombs and wilkinson (1969), who propose for these, and alkaline lavas in general, three "fractionation lineages". These are (1) alkali basalt - hawalite - mugearite benmoreite - trachyte; (2) basanite - nepheline hawalite - nepheline mugearite - nepheline benmoreite - phonolite; (3) a nephelinite series of restricted compositional range. Except for minor differences these lineages are similar to the differentiation series reviewed above 
for Hawali and Tahfti, suggesting that the continental environment was not an important factor in their development. Although the Otago lavas have reacted to some extent with the underlying silicic besement, indicated by "half digested inclusions of quartzose schist" (Tumer and Verhoogen, 1960, p. 167), (cf. the sandstone inolusions in Comores lavas), this had no detectable effect on the chemistry of the lavas (Coombs and Wilkinson, 1969, p. 496).

The Carboniferous lavas of the Scottish Midland Valley also show many similarities to the Hawailan and Otago lavas, in particular the early eruption through central volcanoes of lavas showing ample evidence of fractionation of olfvine, augite, and plagioclase, followed by a suite of more undersaturated basanites and nephelinites rich in ultramafle inclusions (Machregor, 1948; Upton, 1969).

A similar suite of lavas has been erupted through and intruded into Cretaceous sedimentary rocks in the Balcones province of Texas (Spencer, 1969). According to spencer (1969), these rocks represent two primary magmas. Fractional crystallization of an alkali basalt primary magma produced only small changes in chemical composition. A nephelinite primary magma differentiated, by fractionation of olivine, clinopyroxene, and nepheline into two separate trends. These trends, nepheline basanite - mafic phonolite - phonolite and nephelinite - melilite nephelinite, were, according to Spencer (1969), probably determined by the composition of the fractionating pyroxene. In the East Rift of Kenya and northern Tanzania, great volumes of alkaline magmas have poured out through fissures and individual stratovolcanoes from the Miocene to the present (King and sutherland, 
1960; Williams, 1969). Activity began with olivine phonolite eruptions, followed up to the Quaternary with irregularly alternating phases of predominately alkalic basalt, basanites and nephelinites or phonolites, trachytes and nephelinites. Saggerson and Williams (1964) divide these rocks into an ankaratrite - melanephelinite - nephelinite - phonolite series and an alkali basalt - trachybasalt - trachyte series, each of which they consider to be derived independently from some common source, possibly alkali peridotite, in the mantle, and differentiated by fractionation of olivine and other unspecified phases.

Varne (1968) recognized two similar series from Moroto Mountain, Uganda, and proposed thet incongruent melting of pargasite gave rise to the nephelinite series, and that partial melting of the peridotite produced the alkali basalt series. However, Wood (1968) suggested that low concentrations of $\mathrm{Rb}, \mathrm{Sr}, \mathrm{Ba}, \mathrm{Zr}, \mathrm{Nb}, \mathrm{Y}$ and $\mathrm{La}$ and high $\mathrm{K}: \mathrm{Rb}$ and $\mathrm{K}: \mathrm{Ba}$ ratios in the pargasite of these rocks invalidated Varne's hypothesis. Wood concluded that high pressure fractionation of magnesian clinopyroxene, along with wall-rock reaction during ascent, could produce the olivine nephelinites; these, by fractionation of olivine and spinel, could produce the olivine-poor nephelinites.

\subsubsection{Summaxy}

The above brief review has shown that:

1. There are numerous occurrences, in both oceanic and continental crustal environments, of rocks petrologically similar to those of the comores. Hence any petrological conclusions from the present study should be of some general significance. 
2. Although motasomatism, alkali transport, partial melting, and other processes have been proposed to account for the formation of such rocks, fractional orystallization of a basic magma is that most cormonly accepted. Any such process might be valid for the Comores.

3. Much attention has been given to explaining the differentiation of these suites from the "parent magma", but little attention has been given to explaining the actual origin of the "parent magna" in question, a surprising fact in view of the theoretical and experimental interest in this problem.

\section{3. THE PRESENT STUDY}

The present study has been confined to Grande Comore since it displays the simplest geology and petrology of the group, and is consequently most amenable to a detalled petrochemical study, especially with regard to the genesis of any primary magma. At the same time it may well display relatively primitive stages of volcanic evolution through which the older Comores volcanoes themselves passed in their earlier development. Furthermore, should the study reveal little of general petrological significance, it would be of some intrinsic local value as a contribution to the geological knowledge of the archipelago as a whole. In this light, the objective of the present study is to provide an accurate geological and geochemical description of Grande Comore, and attempt to explain the petrogenesis of the lavas in the hope that any such explanation may be applicable to the many other occurpences of similar lavas. 


\section{GEOLOGY OF GRANDE COMORE}

2.1. INTRODUCTION

A complex interplay of erosional and volcanic activity results in rugged topography on the three islands of Anjouan, Mohel1, and Mayotte, making field-investigations slow and difficult. On Grande Comore, however, constructional volcanic activity has been dominant, and the island has a relatively smooth and undissected topography. The resulting lack of vertical sections does, unfortunately, limit fleld work to sampling the thin veneer of lavas covering the island.

The present study is based on field work carried out over two separate periods, two weeks during the summer of 1967 , and three weeks during the summer of 1968. The extensive network of roads and footpaths permitted rapid coverage of most of the island, and a representative sampling of the island was obtained. This, in confunction with study of the aerlal photographs and topographic map was considered adequate for the present investigation. There is no doubt, however, that refinements and additions could be made, especially with the aid of drilling or geophysical techniques. 2.2. TOPOGRAPHIC UNITS OF GRANDE COMORE

2.2.1. Introduotion

De Saint Ours (1960) divided Grande comore into four topographic units. These are, from north to south, the Massif de la Grille, the Diboini Plateau, the Massif de la Kartala, and the Massif de Badjini. These subdivisions are retained by the present writer, although not always with the same geological significance as given to them by De Saint Ours. 
2.2.2. Massif de la Grille

The Massif de la Grille comprises the northern third of Grande Comore (Fig. 3). It has the form of a gently sloping dome about $15 \mathrm{~km}$ in diameter and 1087 metres high. It is slightly elongated in an ESE direction, with surface irregularities resulting from some 120 pyroclastic cones (Figs. 3, 4a). The slopes of this dome do not exceed $7^{\circ}$ on the west and north, but the eastern slopes are steeper (up to $16^{\circ}$ ) and slightly concave (Fig. $4 a$ ).

2.2.3. Diboin1. Plateau

The Diboini Plateau was not precisely defined by De saint Ours (1960), but used only to Indicate the broad saddle between La Grille and Kartala. In the present study, the Diboini Plateau refers to the region indicated on Fig. 3 by the narrow NW-trending defile between Kartala and La Grille reaching a maximum height of 600 metres. It emphasizes the elear topographic break between La Grille and Kartala volcanoes, and is belleved to represent a zone of interdigitation of lava flows from each.

2.2.4. Massif de la Kartala

The Massif de la Kartala forms an elongate dome, about $30 \mathrm{~km}$ In diameter at sea level and 236 metres above sea level, which makes up over half the island of Grande Comore (Fig. 3). It is elongated towards NNW and SE, due to fissure eruptions concentrated in these directions, and these elongations are hereafter referred to as the NNW and SE fissure zones. The western Kartala slopes have an average value of $15^{\circ}$ (much steeper than those of La Grille) while 
Fig. 3.

Topographic map of Grande Comore
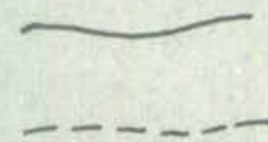

H.

(11111/114/1/)
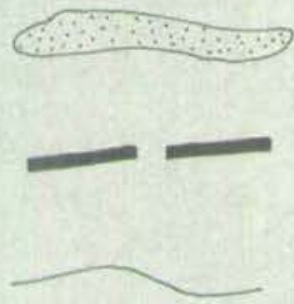

$\longrightarrow$

Roads

Footpaths

Pit crater

Approximate boundary of anolent marine platform

Coral reef

Topographic boundaries

Topo. contours at 100 meters

A- B etc. Locations of profiles given in Fig. 4. 


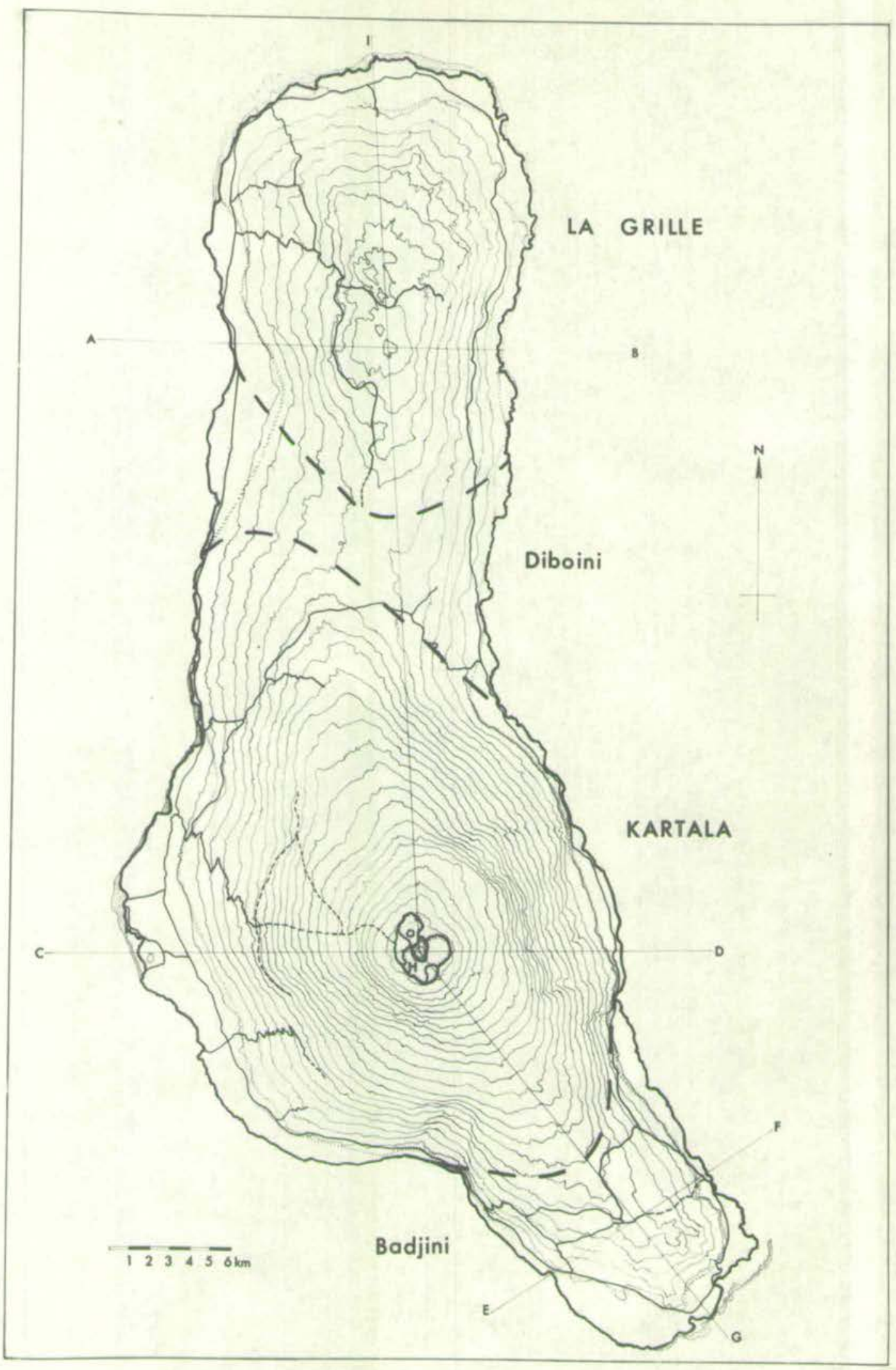


Fig. 4 .

Proflies of Grande Comore

a. La Grille

b. Kartala

c. Badjini

d. Longitudinal profile (note different scale from $a, b$ and $c$ ) 


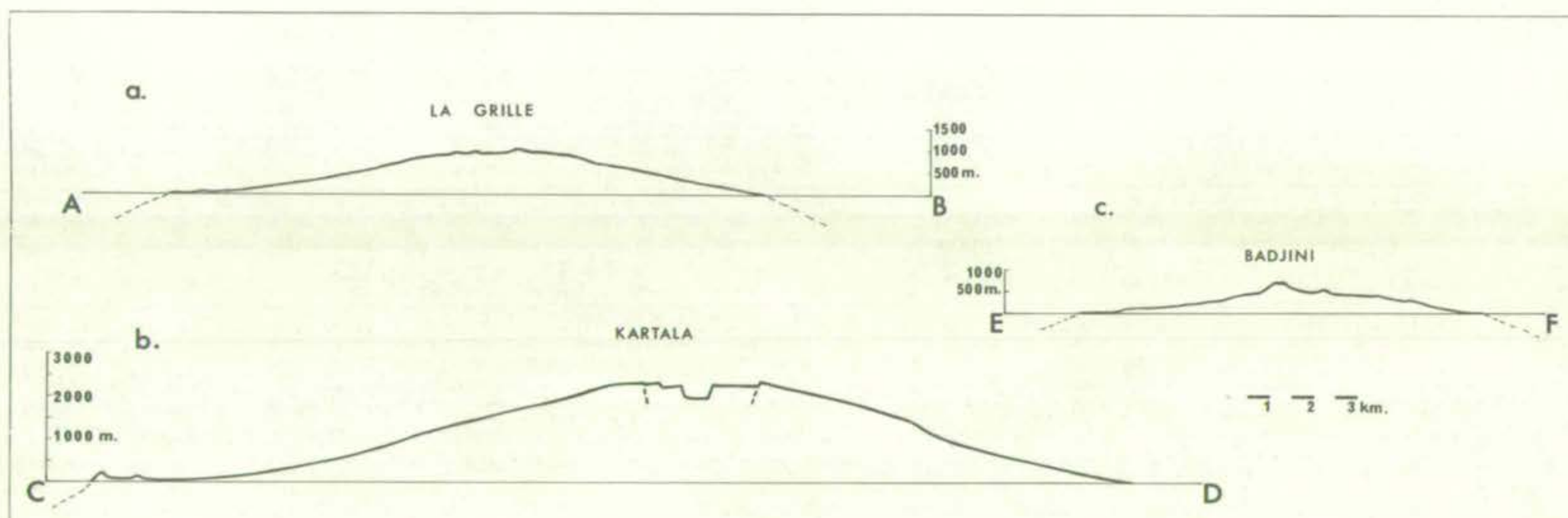

d.

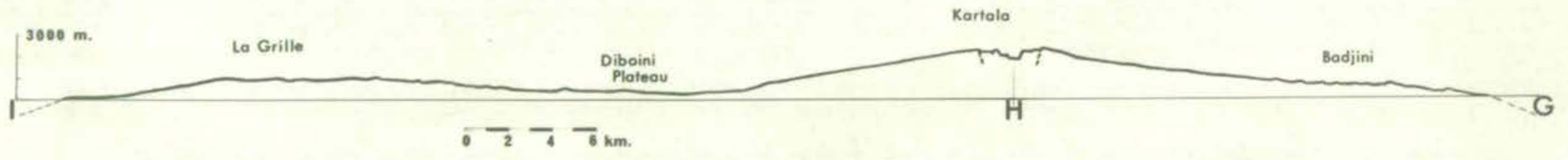


the eastern slopes are steeper, showing the coneave form described for the eastern slopes of La Grille (Fig. 4b). The massif is capped by a steeper dome, with average slopes of $24^{\circ}$, truncated by the Kartala calderas. De Saint Ours (1960) considered this dome to be formed of interbedded lava flows and pyroclastic material, 1.e. to be a composite cone, but the caldera sections show that pyroclastic rocks are rare. Pyroclastic cones are far less common on Kartala than La Grille.

2.2.5. The Badjini Peninsula

The Badjinf Peninsula is a prominent extension of the Kartala dome along the SE fissure zone (Fig. 3). De seint ours considered It to represent a separate volcanic center older than Kartala, but no evidence was found for this in the present investigation. It is explicable as resulting from voluminous eruptions along the southeast fissure zone of Kartala. This is supported by Fig. Ld, which shows no topographic break between Badjinl and Kartala, as found for example between Kartala and La Grille at the Diboini Plateau, and as one would expect if there was a separate Badjini volcano. There is also a strong similarity betwean the east-west profiles of Kartale (Fig. $4 \mathrm{~b}$ ) and Badjini (Fig. 40) suggesting that they result from similar volcanic and erosional activity. Furthermore, the great majority of lavas in this area are petrologically and chemically similar to those of Kartala. Nevertheless, several exposures on the Badjini Peninsula are surrounded by deep soil, and consequently appear to consist of lavas more ancient than any other Kartala lavas, and possibly unconformably overlain by them. It is useful to distinguish these by the term "Badjini lavas". 


\subsection{GEOLOGICAL MAP OF GRANDE COMORE}

The geological map of Grande comore, Iike the topographic map described above, is based on the 1:50,000 scale topographle map of the Island published by the Institute Geographique National of France. It was prepared from aerlal photographs, the field observations desoribed below, and the petrographic and chemical studies to be described in subsequent chapters.

\subsection{LAVA FLOWS}

\subsubsection{Sites of eruption}

Where not obscured by soil or vegetation, the sites of lava eruption are commonly marked by breached cinder cones, which suggest that a gas phase separated from the magma preceding these eruptions. For some flows, $\theta . \mathrm{g}$. the 1880 flow on the Badjinf Peninsula near Nioumamilima (Fig. 5), these cones are aligned and coalesce, presumably defining the outcrop of flssures. Some flows, e.g. those of 1860 and 1918 (Fig. 5), emanate from fissures whose outcrop near the caldera is marked by a linear valley, with very minor pyroclastic material present. Still others, such as the 1859 and 1872 flows on the west coast (Fig. 5), have neither cones nor valleys marking the site of emission, but the alignment of their upper ends suggest that they were emitted from a single fissure. The fact that both Kartala and La Grille are elongated domes is taken as more general evidence for the dominance of fissure eruptions in their formation, at least in the later stages. 
Fig. 5 .

Goological map of Grande Comore

负

E)

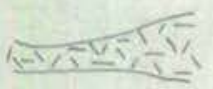

C

$\Delta$

$\Longrightarrow$

- Fissures

_... Roads and footpaths

Coral reefs
Byroclastic cones

Craters

Historic lava flows (with dates where known)

Analysed samples from La Grille

Approximate geochemical boundary between Kartala and La Grille

"Kartala 


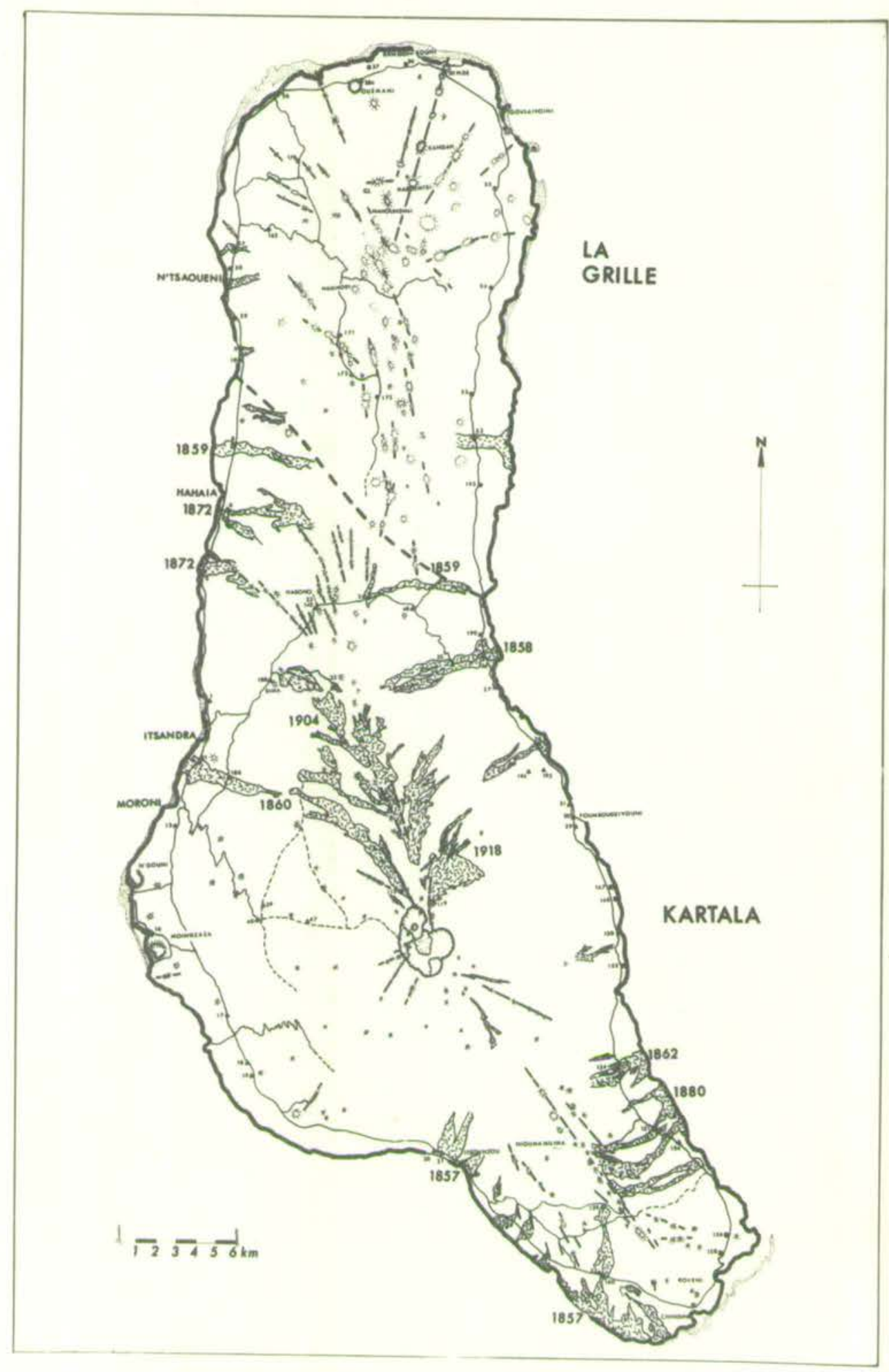


2.4.2. Dimensions of flows

The unvegetated lava flows, mostly dated as less than 150 years old, are clearly visible on aerial photographs, and so their lengths and widths can be accurately established. They show a range in length from $17 \mathrm{~km}$ (the 1860 Itsendra flow, Fig. 5) to less than $1 \mathrm{~km}$ (excluding possible submarine extensions). They generally increase in width downslope, to a maximum observed width of $6 \mathrm{~km}$, but generally about $1 \mathrm{~km}$ wide.

The thicknesses of these lava flows are shown in numerous exposures provided by coastal cliff-sections, river channels, and caldera walls. There is no apparent difference in thickness between flows of Kartala or La Grille. Most are between one and three metres thick, and a typical coastal exposure is shown in Plate 1. The thickest coastal exposure observed was that of the feldspar-phyric flow near Foumboudzivouni. Its thickness was estimated at ten metres, but this may be excessive since the dip of separate units is highly variable and the true thickness may not have been measured. The horizontal flows exposed in oaldera walls reach thicknesses up to $30 \mathrm{~km}$, almost certainly a result of ponding within the caldera walls. The volume of lava produced in the average eruption is estimated at around $1.5 \times 10^{6} \mathrm{~m}^{3}$, less than a tenth of that for the average historic eruption in Hawali (of. Macdonald, 1967, Table 1). 2.4.3. Structures of flows

All uneroded lava flows observed on Grande Comore can be described as as, rather than pahoehoe type, with their surfaces covered by a chaotic jumble of jagged, spinose blocks. 
The centers of these flows are massive and often columnar-jointed the best examples of which are seen in the caldera walls, Plate 2. In some cases along the shore, the blocky surfaces have been removed by erosion, displaying small scale flow structures which could be described es pahoehoe.

Although lava tunnels do not appear characteristic for aa flows (cf. Macdonald, 1967), numerous examples can be found on Grande Comore (see Prosper1, 1957). One such tunnel was examined in the present study, on the west coast between Hahala and N'Tsaouenl. The roadside entrance to this tunnel is about one metre in diameter and the tunnel is about four metres wide at the floor, two to three metres high in the center, with the roof curved down to the flat floor whioh is covered by fallen blocks. The tunnel extends for at least 200 meters, but its total length was not determined. Small hollow stalactites were collected from the roor, as well as a orust of calcite apparently resulting from groundwater deposition.

The lavas of Grande Comore are mostly dark grey with variable amounts of phenocrysts. The Kartala flows contain mostly phenocrysts of olivine and clinopyroxene, with rare plagloclase phenocrysts. The Foumboudzivoun plagioclase-phyric flow is particularly striking, showing, along with large elinopyroxene crystals, a range of sizes and orientations of plagioclase phenocrysts, from large (up to $2 \mathrm{~cm}$ ) rosetie-like clusters to the smaller flow-aligned laths, (plate 3). Only olivine phenocrysts are common in the lavas of La Grille, but rare clinopyroxenes can be seen.

Vesioularity of the lavas is highly variable, within flows as 
well as between flows, and a quantitative estimate of vesicularity is given in chapter 3 (Fig. 10). The type of vesicles varies from pipe vesicles, developed in the lower parts of elat-lying flows, to the cellular spatter which makes up most of the 1965 caldera flow.

\subsection{HISTORIC VOLCANIC ACIIVITY}

Both Kartala and La Grille voleanoes have been historically active, but the bulk of this activity has been confined to Kartala. The dates of flows shown on the mep of $\mathrm{Fig}$. 5 were taken from De. Saint Ours (1960) and Lacrolx (1938). Some undated lava flows have been mapped as "hlstoric" (Fig. 5) because thelr complete lack of vegetation gives them a distinctly youthful appearance. However, one should make the reservation that a difference in elimate, as well as age, controls the development of a vegetation cover, and lavas on the drier leeward parts of the 1sland would take longer to become vegetated. The unvegetated "historic" flows of La Grille volcano are all undated, implying that they are appreclably dier than those of Kartala.

The historic Kartala flows have been mostly erupted from fissures on the northern and southern rift zones of the dome, with no apparent correlation between geographic location and date of eruption (of. Kilauea, Jagger,1947). Since 1918 the activity has been confined to the Kartala caldera. The available descriptions of historic activity are given in Table 2, taken mostly from Van Padang (1963), and personal accounts by residents of Grande Comore. 
Table 2

Historic volcanle activity on Grande Comore

Date

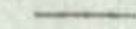

May 1828

1830

1848

July 1855

$$
\text { Bffects }
$$

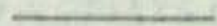

Type

Chemical Analysis of lava

Eruption in parasitic crater

\begin{tabular}{|c|c|c|c|}
\hline & 1848 & $\begin{array}{l}\text { Eruption in radial fissure with } \\
\text { lava emisaion }\end{array}$ & \\
\hline July : & 1855 & $\begin{array}{l}\text { Eruption in parasitic crater with } \\
\text { normal explosions and lava } \\
\text { emission }\end{array}$ & \\
\hline & 1857 & $\begin{array}{l}\text { As above, along with caldera } \\
\text { explosions }\end{array}$ & Strombolian \\
\hline & 1858 & $\begin{array}{l}\text { As above, without caldera } \\
\text { explosions }\end{array}$ & Strombollan \\
\hline & 59 & As above & Strombolian \\
\hline & 1860 & Large lava flow from caldera & \\
\hline & 1862 & $\begin{array}{l}\text { Parasitic crater with lavea } \\
\text { omission }\end{array}$ & Strombollan \\
\hline & 1865 & Parasitic crater & \\
\hline & 1872 & $\begin{array}{l}\text { Parasitic orater with much } \\
\text { vapour and lava emission }\end{array}$ & Hawailan \\
\hline & 1876 & As above & \\
\hline & 1880 & $\begin{array}{l}\text { Eruption in radial fissure with } \\
\text { vapour and lava emission }\end{array}$ & Strombolian \\
\hline March & 1883 & $\begin{array}{l}\text { Eruption in parasitic crater, } \\
\text { with vapour and lava emission, } \\
\text { arable land destroyed, and } \\
\text { people killed (?) }\end{array}$ & \\
\hline & 1884 & $\begin{array}{l}\text { Eruption in radial fissure, lava } \\
\text { emission, arable land destroyed }\end{array}$ & \\
\hline & $\begin{array}{l}\text { - June } \\
1903\end{array}$ & $\begin{array}{l}\text { Flank exuption at } 1600 \text { meters } \\
\text { altitude; much suffocating } \\
\text { gas, } 17 \text { poople killed. }\end{array}$ & \\
\hline
\end{tabular}


Feb 25 to

March 1904
Eruption in radial fissure with lava enission; arable land destroyed, people killed

Aug $\begin{array}{r}11-26, \\ 1918\end{array}$

Strong phreatic eruptions; large flank lava flow: Chagnoureni pit crater formed

Apr. 22, May 4 , June 13-16, 1948

Feb. 1952

$1953-1965$

July 1965

Great black clouds; strong tremors; eruption in lava lake; possible parasitic eruptions

Explosions and vapour emission in caldera

Fumarole activity

Lava and vapour emission from fissure on caldera floor; Brush fires started by bombs

Oct. 1967 Tremors, felt as far away as An jouan

Jan. 1968 Tremors, felt as far away as Moroni.
Strombolian $X$

Vulcanian and Hawalian

Strombol1an 
2.6. PYROCLASTIC CONES

2.6.1. Introduction

Stearns and Vaksvik(1935) have subdivided the secondary cones of Oahu, Hawail into three types, viz. lava, cinder, and tuff cones. Each of these has a characteristic profile, the latter two of which are reproduced in Fig. 6. Although few secondary cones of Grande Comore have received detalled field study, it appears from the topographlo maps and aerlal photographs that they fall into one of these two categories, and assuming that these profiles are reliable indicators, the majority appear to be cinder cones.

\subsubsection{Cinder cones}

Most cinder cones of Grande Comore are concentrated in the central parts of the island along the rift zones of each volcano. They are abundant on the crest of La Grille but rare on the higher parts of Kartala. They are similar in profile and size to that shown in Fig. 6, and reach a maximum size of 600 metres diameter and 140 metres high. Many are aligned along fissures (Plate 4 ).

The Haboho einder cone, on the NW rift zone of Kartala volcano (see Fig. 5), was the best studied example in the present investigation. It is composed entirely of black, glassy, highly vesicular (cellular) cinders and pumice, 1.e. entirely magmatic ejecta. It has been extensively quarried, and is consequently well exposed in a quarry section about ten metres high (Plate 5). The material was deposited in distinct layers, dipping about $30^{\circ}$. A thin soll zone about $50 \mathrm{~cm}$ from the top reflects a pause in activity before it completely ceased. Two chemical analyses have been made of pumice 
a.

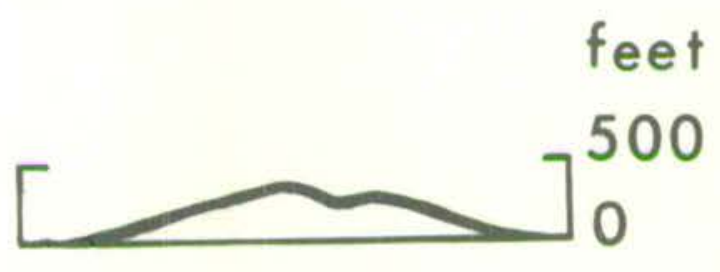

b.

feet
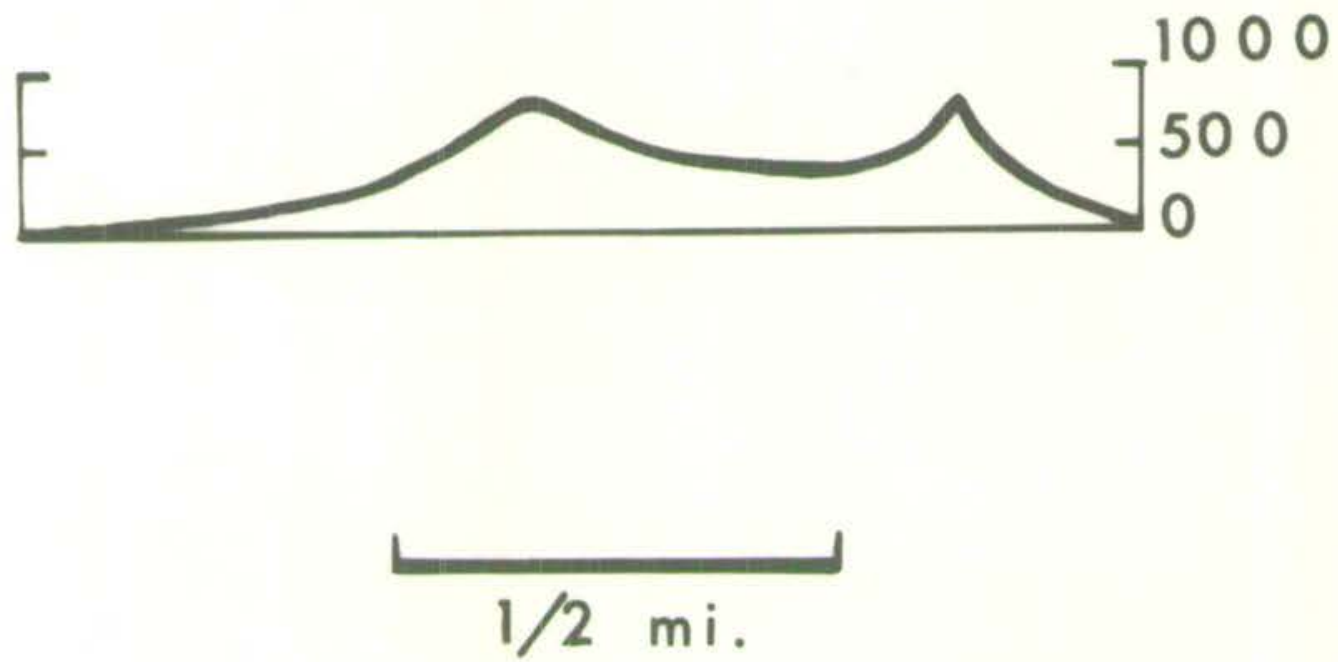
from different parts of this cone (23 and 142, Tables B-1 and $\mathrm{C}-1$ ). Weathering of the basaltic cinder causes a change in colour from black to yellow-brown, a good example of which is seen in the quarried cone near sima (Plate 6). The layered cinder of this cone is cut by a sub-horizontal plagioclase-phyric dyke about one metre thick (Plate 6). This dyke has not undergone any weathering (see 188, Tables B-1 and $\mathrm{C}-1$ ), and if 1 ts formation was contemporaneous with the cone, it indicates the much more rapid weathering of the oinders than the lava.

Some oinder cones are completely rounded in profile, with no central depression marking the vent, but rather a capping of cinders (Plate 7). However, most cones have a contral depression, the walls of which are commonly breached, presumably by lava emission (Plate 8).

\subsubsection{Tuff cones}

As shown in profile b (Fig. 6), tuff cones are generally larger than cinder cones, and have large central flat-floored craters which have diameters of about half the total diameter (Stearns and Vaksvik, 1935). The tuff cones of Grande Comore, although similar in profile to those of Oahu, are generally smaller, on the average about one $\mathrm{km}$ in diameter as compared to two $\mathrm{km}$ diameter of those on Oahu. As on Oahu, most tuff cones on Grande Comore are found close to the seashore. If the Habointsi and Kandah cones on the northeast papt of La Grille (Fig. 5) are tuff cones, as suggested by their size and form, they are exceptions to this general rule.

Two excellent examples of the Grande Comore tuff cones are $N^{\prime}$ Goun 1 and Molndzaza, found on the west coast just south of Moroni 
(see Fig. 5). The $\mathbb{N}^{\prime}$ Gouni cone (Plate 9) is very similar in form to that of Koko Head, Oahu (Steams and Vaksvik, 1935, Plate 1), but is slightly smaller, with a diameter of $1 \mathrm{~km}$ as compared to the $2 \mathrm{~km}$ of Koko Head.

Brief sampling of $\mathbb{N}$ 'Gouni revealed very few lithic fragments, most samples obtained consisting entirely of olivine, clinopyroxene, and yellow-orange glass fragments. The hand specimens are strikingly laminated, but no detailed study was made of dips of the bedding in this cone. One hand specimen was studied petrographioally and chemically (16, Tables B-1 and $\mathrm{C}-1)$.

The Goulaivoini tuff cone on the northeast coast of the island (Fig. 5), breached by marine erosion, shows the characteristic features of Hawalian tuff cones, and differs from the Molndzaza cone in that lithic material is abundant. Fragments of coral limestone, as well as the lava flows and the ultramafic inclusions which they contain, are found in the Goulaivoini cone, as well as further indand in the Dinde tuff cone (Fig. 5).

2.7. THE KARTALA CALDERA

2.7.1. Description of the caldera

The following summary is taken from the detalled description given by Strong and Jacquot (1969).

The main caldera is formed by the coalescence of at least five smaller calderas which have an average diameter of about 1500 metres (Fig. 7a). These have combined to give the main caldera a roughly elliptical form, about $4 \mathrm{~km}$ by $3 \mathrm{~km}$ (Fig. 7a). Superimposed on this elliptical form sre the two sets of NNW- and N-trending regional 


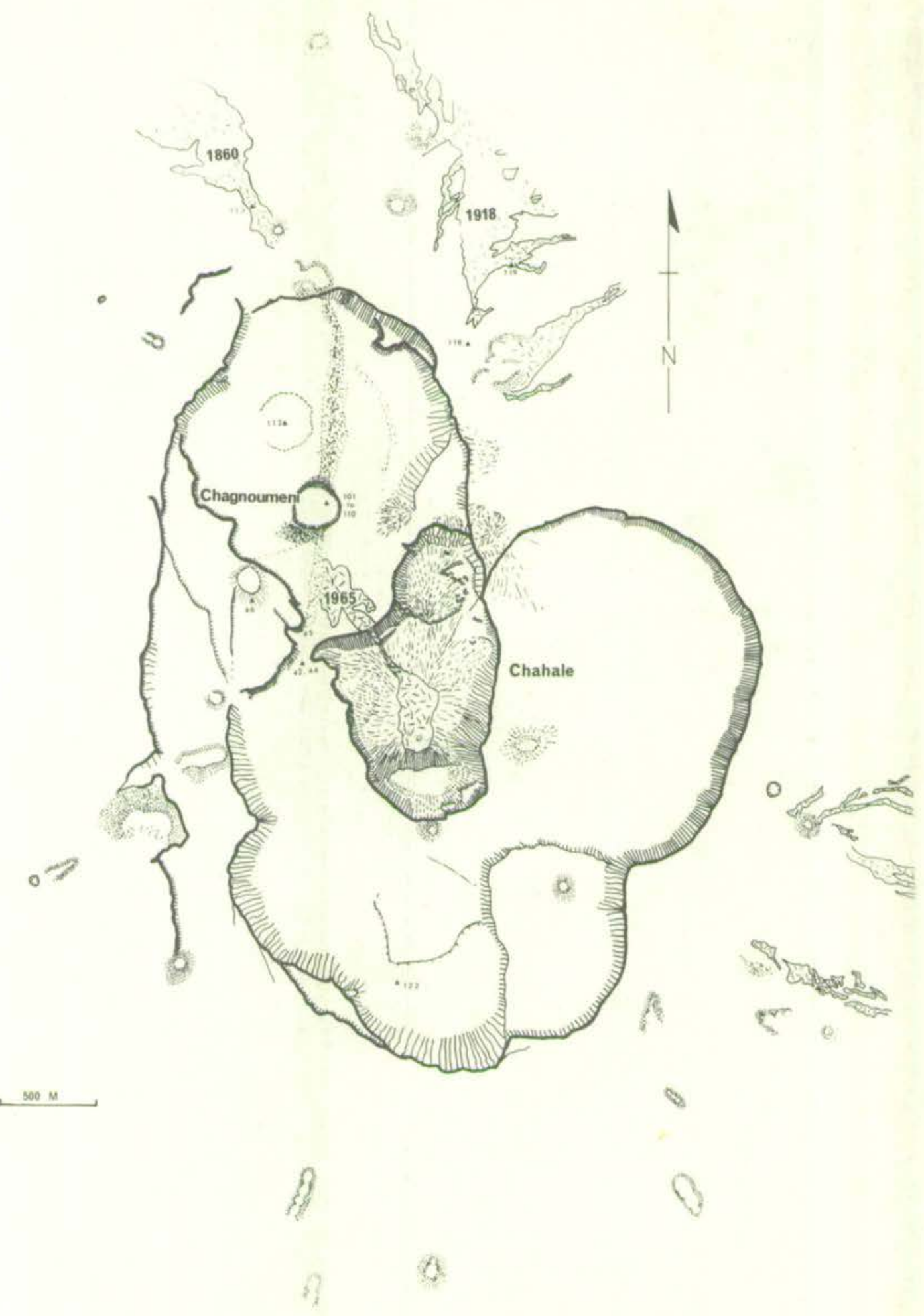


fissure systems, as well as local radial fissures. The caldera walls dip inwards from $90^{\circ}$ to $70^{\circ}$, but only the vertical walls are unvegetated and uneroded (Plate 10).

The floor of the main caldera complex is broken by two pit craters (Fig. 7a, Plate 10). The southern pit orater, Chahale, is 1300 by 800 metres across and 300 metres deep. Chagnuomeni. pit crater, about one $\mathrm{km}$ north of Chahale, is cylindrical in form, 250 metres in diameter and 30 metres deep. According to Lacrolx (1938), Chagnuomeni was formed during the 1918 eruption.

The walls of these pit craters provide sections through some of the thick (up to 30 metres) horizontal lava flows which presumably ponded in the caldere (Plate 2). Chemical analyses of the bottom and centre of one of these flows are given in Table C-1 (101 and 102). Several thin vertical basaltio dykes cut these flows (Plate 11), and chemical analyses of these dykes are given in Table C-4 (105, 107, 110)

A straight, north-trending fissure zone runs through the central part of the northern half of the caldera floor (Fig. 7a), and it was from this fissure that the 1965 flow was emitted. This flow has been accurately surveyed by $C$. Jacquot, and its volume estimated at $1,500,000$ cubic metres, similar to the average volume of flank eruptions. One specimen from the surface of this flow has been analysed $(23$, Tables $B-1$ and $C-1)$.

Many angular blocks, almost certainly brought from depth during explosive activity, have been strewn over the caldera floor, especially around the Chahale pit crater. Many of these are of porphyritic ankaramitic basalt, whlle some are sufflelently coarse to be described 
as dolerite and gabbro. It is uncertain whether these coarsergrained blocks were derived from thick lava flows or from intrusive bodies, but they have been listed as intrusive rocks for present purposes. Two chemical analyses of these are given in Table C-4 $(42$ and 44$)$.

2.7.2. Formation of the caldera

Judging from the relative amounts of erosion and vegetation of the various fault scarps and walls of the caldera, the following sequence of events might be postulated. After completion of the Kartala dome, the stresses producing the regional north-south fissure systems still prevailed, facilitating graben-type collapse along fractures 1 and 2 (FIg. 7b). A gradual lessening of this regional stress, 1.e, an effective increase of vertical stress, resulted in the development of radial and circular fractures. Subsequent oruptions emptied the underlying magma chambers, removing support, and causing collapse along the oircular fractures, resulting in formation of the calderas in the sequence a to $\underline{e}$ (Fig. $7 \mathrm{~b}$ ). During the flank eruption of 1918, the calderas $\underline{h}$ (Chagnuomeni pit crater) and $\underline{g}$ were formed by collapse and explosion respectively.

As these regional fissures, radial fissures, grabens, and circular fractures represent a striking combination of the features discussed by Robson and Barr (1964), it is instructive to try and interpret the stress system in the light of their theoretical predictions. In applying these predictions to the Kartala caldera we might best assume that throughout the development of these features there was a vertical stress ( $p_{\max }$ ) which was greater than either of 
Fig. $7 b$.

Sohematic outline of the separate collapse calderas (a to $\underline{h}$, in order of formation) and graben-type fractures (1 to 5 , in order of formation) which combined to produce the Kartala caldera. 


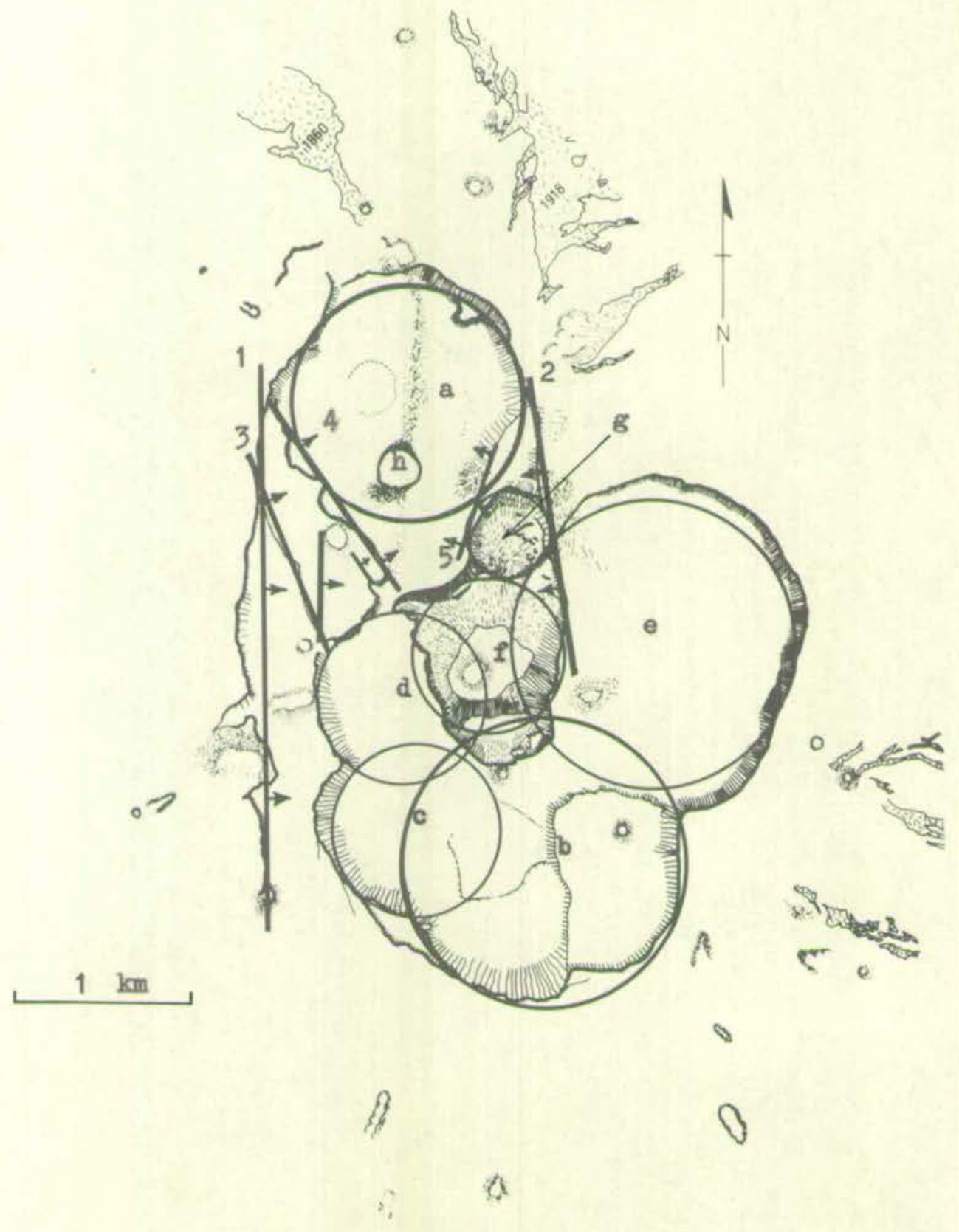


two horizontal stresses ( $p_{\text {min }}$ and $p_{\text {int }}$ ), a reasonable assumption since a very considerable force is needed to transport the magma upward to the surface in the first place. We must then assume that at the beginning of volcanism via the regional fissures $p_{\text {int }}$ was much greater than $p_{m i n}$; this also seems perfectly reasonable because otherwise the fissures would not have formed at all. As the Kartala shield volcano $\mathrm{grew}, \mathrm{p}_{\text {int }}$ appears to have approached $\mathrm{p}_{\mathrm{min}}$ in value, which could have taken place by an actual equalization of these regiona: stresses, or more probably by a local equalization due to increasing diffleulty in transmitting stress through the growing pile of lava. Associated with this equalization of stresses was an increasing tendency for central type eruptions to take place, resulting in buildup of the dome. After formation of the dome, however, there must have remained sufficient difference in these horizontal stresses to cause the initial graben-type collapse postulated above. When the stresses were more or less equalized, the small circular calderas and radial fractures were formed. Thus, using reasonable assumptions about the stress environment, the theoretical considerations of Robson and Barr (1964) oan be used to explain the observed features. Using these same assumptions, a more detalled application of their predictions can be made to try and deduce something about the deeper structure of the volcano.

Robson and Barr (1964, pp. 326-327) consider that when $p_{\max }$ is vertical and applied at a depth greater than $4.7 \mathrm{~km}$, and $p_{\text {int }}=p_{m i n}$, shear fallure should occur in the form of Inward-dipping fractures, with the resultant caldera about $4 \mathrm{~km}$ in diameter and increasing in 
diameter with greater depth of the magma chamber. The walls of Kartala caldera appear to flt this requirement, and some of the widespread radial fractures (e.g. see Fig. 5) also appear to require a very deep source of upward pressure. However, the Kartala caldera results from the clustering together of individual smaller calderas which, according to the theorles of Robson and Barr, are too small to have formed by shear fallure from a deep source of upward stress.

The other possibility discussed by Robson and Barr (1964, pp. 326-327) for shallow magma chambers, i.e. at a depth less than $4.7 \mathrm{~km}$, with $p_{\max }$ vertical and $p_{\text {int }}=p_{m i n}$, shows that the stress can be relieved by a single arcuate tension crack dipping outwards at an angle greater than $60^{\circ}$, or by vertical tension cracks radiating from the centre of stress. In the former case the arouate cracks would form segments of a circle which form a ring dyike. As described above, the walls of the small clrcular calderas that are visible at the surface are vertical in the two cases where very recent and uneroded, and therefore possibly have been so in all cases. They may therefore be the surface expression of ring dyke type of fractures expected from shallow magma chambers. Although Robson and Barr do not make any statement concerning the relationship between diameter and depth of this fracture type (except that the magma chamber is less than $4.7 \mathrm{~km}$ deep), it appears that the Kartala caldera is most likely to have resulted from these ring-dyke type of tensional fractures rather than shear fallure along inward-dipping cone-sheet type of fractures. 


\subsection{EROSIONAL FEATURES}

\subsubsection{River erosion}

As noted above, the whole 1sland of Grande Comore is asymmetrical in east-west proflle, with the concave eastern slopes steeper than those of the west. Because the eastern slopes face the prevalling winds, precipitation and run-off is far higher on the east coast than the west. Thus, the asymmetry apparently results from different climatio conditions on opposite sides of the island. Nevertheless, the relative insignificance of erosion in determining the gross topography of Grande Comore must be a reflection of the high productivity of both voloanoes. It is possible, however, that long periods of dormancy have occurred in the past and that eroded landscapes have subsequently been obliterated by renewed volcanlsm. This has been suggested by De Saint Ours (1960) for the Badjini Peninsula, but no evidence was found in the present study to support such an hypothesis. 2.8.2. Marine erosion

Surrounding most of Grande Comore is a narrow, gently sloping plain which is separated from the central parts of the island by an abrupt change in slope (FIg. 3), occurring at about 25 to 100 metres above sea-level. This plain, varying in width from 0 to $3 \mathrm{~km}$, is Interpreted by the present writer as a wave-out platform resulting from a former period of relatively higher sea level. The change in slope is thought to represent ancient sea cliffs, now mostly covered by younger lava flows. This platform is narrowest near the main rift zones (FIg. 3), presumably due to higher volcanic activity in these areas. 
The changes in sea-level are thought to be eustatic rather than due to uplift of Grande Comore, since it seems unlikely that the whole island could undergo an equal amount of uplift. Furthernore, similar features are seen on the other comores islands, as well as other 1slands of the Indian Ocean (of. Gardiner, 1936; Upton and Wadsworth, 1966; Veeh, 1966).

2.8.3. Reefs

As shown in Fig. 3, fringing coral reefs are discontinuously developed around Grande Comore, and they are lacking in areas of higher volcanic activity, coinciding with the narrowest parts of the wave-cut platform (FIg. 3). The narrowness and discontinuity of these reefs compared with those of Mayotte serves to emphasize the great difference in age between these two islands.

\subsection{SUMMARY}

The island of Grande Comore is made up of two shield volcanoes, La Grille in the north and Kartala in the south, separated from one another by a zone of lava interdigitation referred to as the Diboin1 Plateau. Both volcanoes have been historically active, but since 1918 the activity has been confined to the caldera complex atop Kartala. The slopes of Kartala (at $15^{\circ}$ ) are steeper than those of La Grille (at $7^{\circ}$ ), and the whole lsland has an asymmetrical east-west profile due to the prevailing easterly winds.

Pyroclastic cones are common on each volcano, but are much more abundant on La Grille than on Kartala. Their alignment in specific zones indicates that fissure eruptions have been important in the formation of each voloano. 
The lavas of Kartala contain phenocrysts of olivine, elinopyroxene, and plagioclase, whereas only olivine and rare clinopyroxene phenocrysts are found in those of La Grille. 


\section{PETROGRAPHY OF THE LAVAS}

\subsection{INTRODUCTION}

Both Lacroix (1922) and De Saint Ours (1960) Indicated that all lavas on Grande Comore are basaltic, but they did not recognize any differenoes between the lavas of Kartala and La Grille. Thus, they described basalt, "andesitic basalt", "labradoritic basalt", limburgite, "basanitic ankaratrite", ankaramite, and oceanite, but attached no significance to the geographic distribution of any rock type. The names "andesitic basalt" and "labradoritic basalt" have little relevance to the present study, and the term "ankaratrite" was misused by these writers (as no biotite-bearing rocks were found). Neither is the term limburgite used in the present rock classification, Although it might properly be applied to some of the glassy lavas of La Grille.

\subsection{LAVAS}

\subsubsection{Classiflcation of the lavas}

The undersaturated basaltic rocks have in the past been given many poorly-defined, redundent, and often inconsistent names, making it difficult to classify any but the most distinetive of rock types. This situation is aggravated by the variety of criteria used in such classiflcations (e.g. modal composition, modal feldspar composition, normative composition, normative feldspar composition, differentiation index), a point discussed in some detail by Coombs and Wilkinson (1969). This difficulty is now particularly unfortunate because there 
Fig. 8 .

Projection of lava norms from plagioclase onto the plane nepheline-diopside-forsterite. (mol. \%)

$$
\begin{aligned}
0 \quad & \text { Kartala } \\
-\quad & =\text { La Grilla }
\end{aligned}
$$




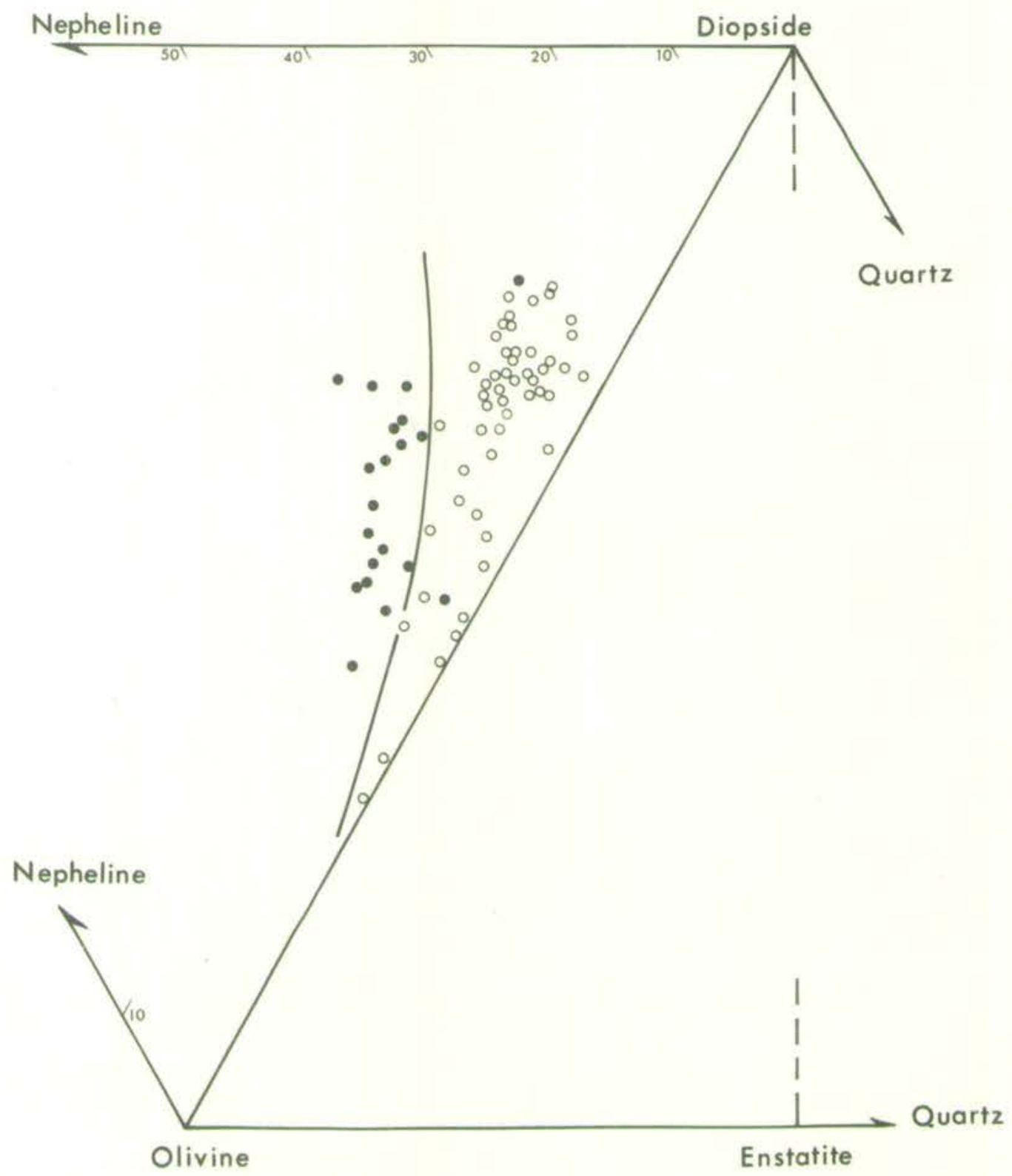


appears to be some divergence between fleld geologists and experimental petrologists, or even amongst experimental petrologists, and the same term may refer to different rocks when used by different workers. For example, "nephellnite" is used differently by Yoder and Tilley (1962) and Green (1969), although each paper seems to refer to rocks described as "nepheline basalt" by Tumer and Verhoogan (1960), and neither uses "nephelinite" as deflned by Johannsen (1938). The objectives of the present classifloation are to (1) outline the differences between the lavas of Kartala and those of La Grille, and (2) provide a simple descriptive terminology for the rocks within each group. As there is a significant difference in normative nepheline content between each group (Table 3), the first of these objectives can be achleved on this normative basis. Thus, Fig. 8 shows that the La Grille lavas may be termed a basanitic group and an alkall basaltic eroup, as suggested by Coombs (1963).

The second objective is met on the basis of petrographic criteria alone, and the definitions of rock terms are given in Table 3. These terms are consistent with general usage (e.g. Lacrolx, 1922; Macdonald, 1949; Yoder and T1lley, 1962), but the quantitative distinctions used for Kartala lavas are unique to the present study. Detalled petrographic descriptions of each analysed specimen are given in Appendix $B$, and representative photomicrographs in Plates 12 to 18. 


\section{Table 3}

Classification of the lavas

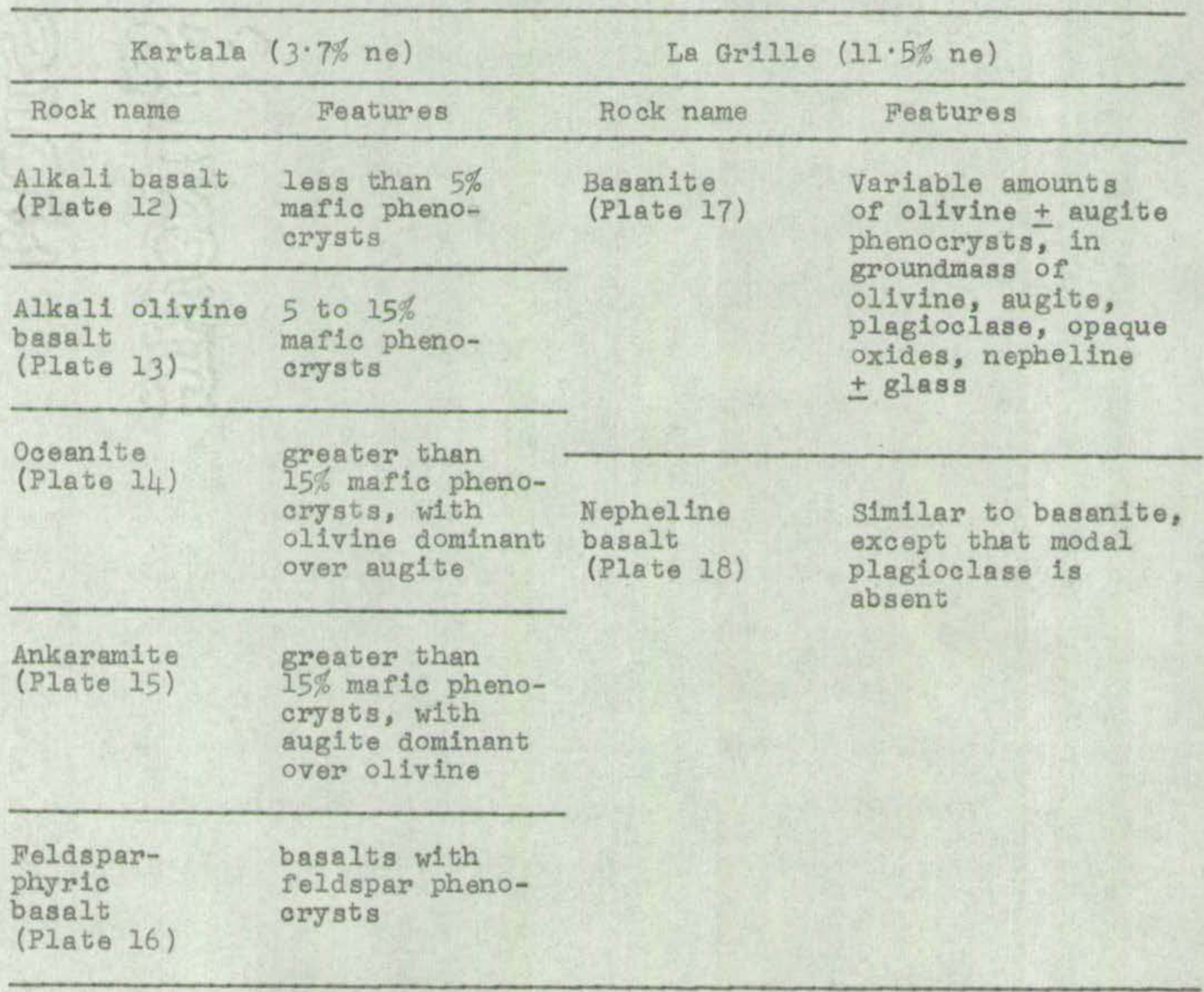

3.2.2. Petrographic contrasts between Kartala and La Grille lavas

In addition to the chemical distinction between the lavas of

each volcano there are consistent petrographic differences which

should be emphasized from Tables B-1 and B-2.

1. Olivine, augite, and plagioclase are found as phenocrysts in Kartala lavas; the phenocryst assemblage in La Grille lavas is 
commonly olivine alone though very rarely the assemblage olivine + minor clinopyroxene is found.

2. Plagloclase is a typieal groundmass phase in the Kartala lavas; It is absent or accompanied by nepheline in La Grille lavas.

3. The analysed Kartala lavas show no sign of alteration; some lavas of La Grille contain slightly iddingsitized olivines.

4. Olivine phenocrysts in the Kartala lavas are mostly euhedral, with only minor signs of resorption or skeletal character (Plate 14). Those of La Grille lavas occur as three distinet types, often in the same rock (Plates 17, 18):

a) euhedral crystals, apparently orystallized in equilibrium w1 th the host lava;

b) skeletal crystals, presumably formed during quenching of the magme;

c) fragmented and resorbed crystals with deformation lamellae, probably derived from disaggregated ultramafic inclusions.

5. Orthopyroxene and translucent spinel crystals occur in the La Grille lavas, and probably these also result from disaggregation of ultramafio inclusions. The orthopyroxenes are surrounded by polysynthetically twinned elinopyroxene (Plate 19), presumably grown as a product of reaction between the orthopyroxene and the basanitic magma. Comparable xenocrysts are, so far as is lmown, wholly absent from the Kartala lavas.

6. Quartz grains, also surrounded by elinopyroxene reaction rims (Plate 20), have been found in two samples of the La Grille lavas, but not in any from Kartala. 
A more quantitative indication of differences between the Kartala alkali basalts and La Grille basanites can be obtained from Fig. 9, which shows histograms of their respective phenocryst volumes. Olivine phenocrysts are relatively abundant in the La Grille lavas, accompanied, if at all, by soarce augite phenocrysts. By contbast olivine phenocrysts are invariably accompanied by substantial amounts of augite phenocrysts in the Kartala lavas, occasionally with an abundance of plagioclase phenoorysts. It should also be noted that the distribution of La Grille phenocrysts is more normal (1.e. gaussian) then that of Kartala.

Figure 10 shows that there is no significant difference in the degree of vesicularity of elther group, at least not as indicated by modal analysis.

3.2. 3. Bad.jini lavas

The Badjini lavas (Table B-3) show petrographic affinities with both those of Kartala and La Grille. Specimens 156 and 158 are similar to the La Grille basanites, while 132, 146 , and 147 are more similar to the Kartala alkali basalts.

3.3. OTHER ROCKS OF GRANDE COMORE

3.3.1. Pyroclastic rooks

Two types of pyroclastic rock have been chemically analysed and studied petrographically.

Basalt1e cinder (samples 23, 46, 122 and 142, Table B-1) consists of cellular basaltic glass, with traces of olivine and/or augite skeletal microphenocrysts.

This material is

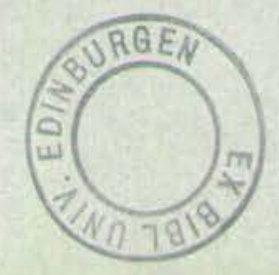


Fig. 9.

Histograms of modal phenocryst contents

In lavas of La Grille (a) and Kartala (b).

Olivine
Augite
Plagioclase
Aphyrio




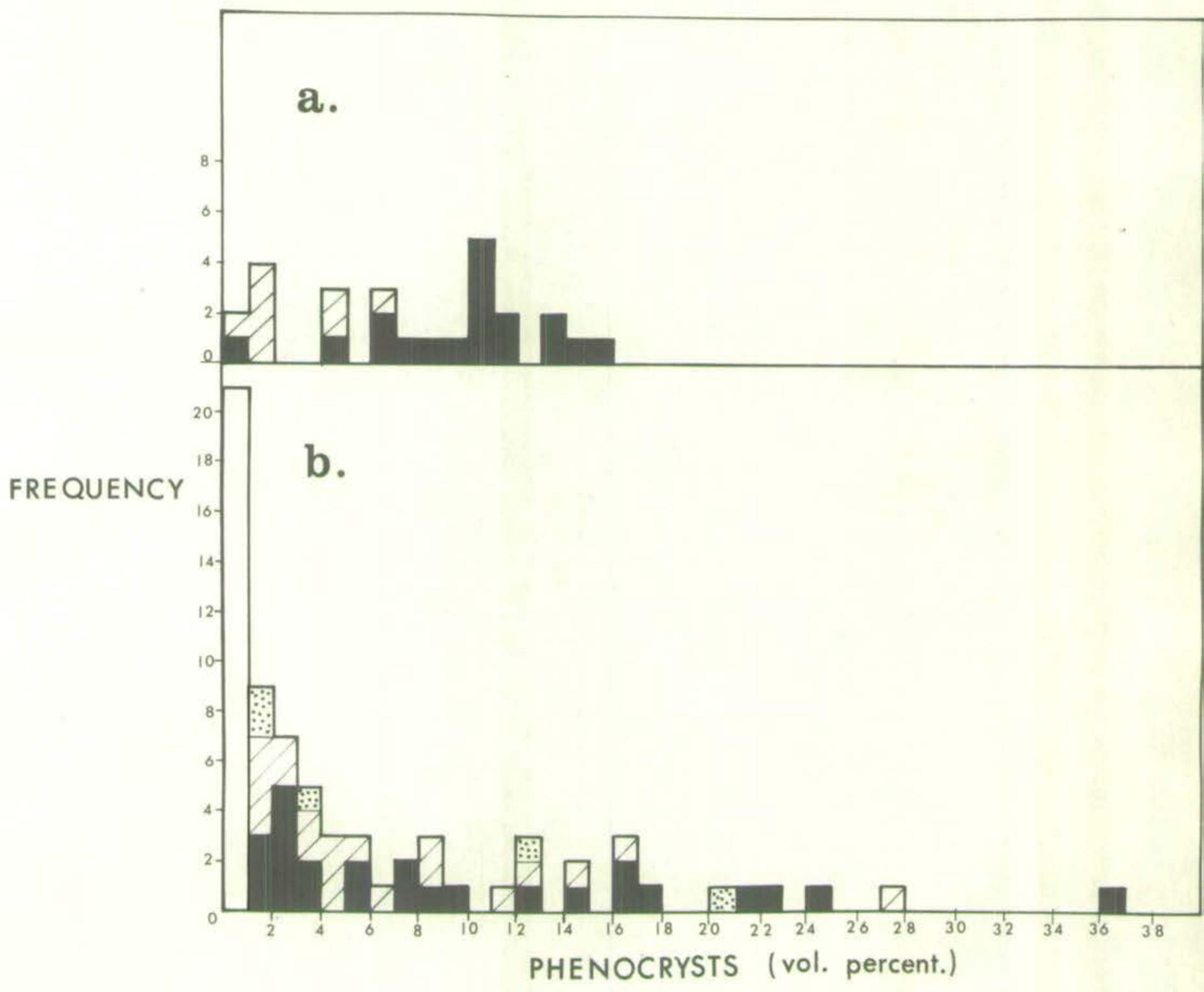


similar, in both microphenocrysts and refractive indices of the glass, to the glassy chilled margins and flow tops of lava flows (c.f. samples 6, 103, 109, and 123, Table B-1).

Finely bedded and friable vitric crystal tuff from the Molndzaza tuff cone consists of fragmented olivine and clinopyroxene phenocrysts in a clear yollow glass. Variation in proportions of these phases (see Table B-3, No. 16) is responsible for the striking fine-scale lamination in this rook.

The pyroclastio cones of La Grille volcano generally show some alteration due to weathering, and consequently were not sampled as thoroughly as those of Kartala, and none at all were chemically analysed. The one reasonably fresh cinder cone, Hamhori (Fig. 5), is formed of brown vesicular (cellular) glass with less then $1 \%$ olivine microphenocrysts, and some small (less than I mim) gabbrolo inclusions. As described in Chapter 2, the tuff cones contain blocks of basaltic, ultramafic, and gabbrole rocks, similar to those described below, as well as limestone blocks. The limestone blocks of Dinde tuff cone (Fig. 5) consist of poorly sorted fragments of bryozoa, forminifera, gastropods, echinoderms, ostracods, abundant green algae, and lava, set in a finer carbonate matrix. It may be described as an algal or foraminiferal biomicrite, probably deposited in a lagoonal environment (Dr. T.P. Sooffin, pers. comm.).

\subsubsection{Intrusive rocks}

The only unquestionably intrusive rocks found on Grande comore are the thin basaltic dykes cutting the lava flows exposed in the walls of the Chagnuomeni pit crater on Kartala (Plate 11). These 


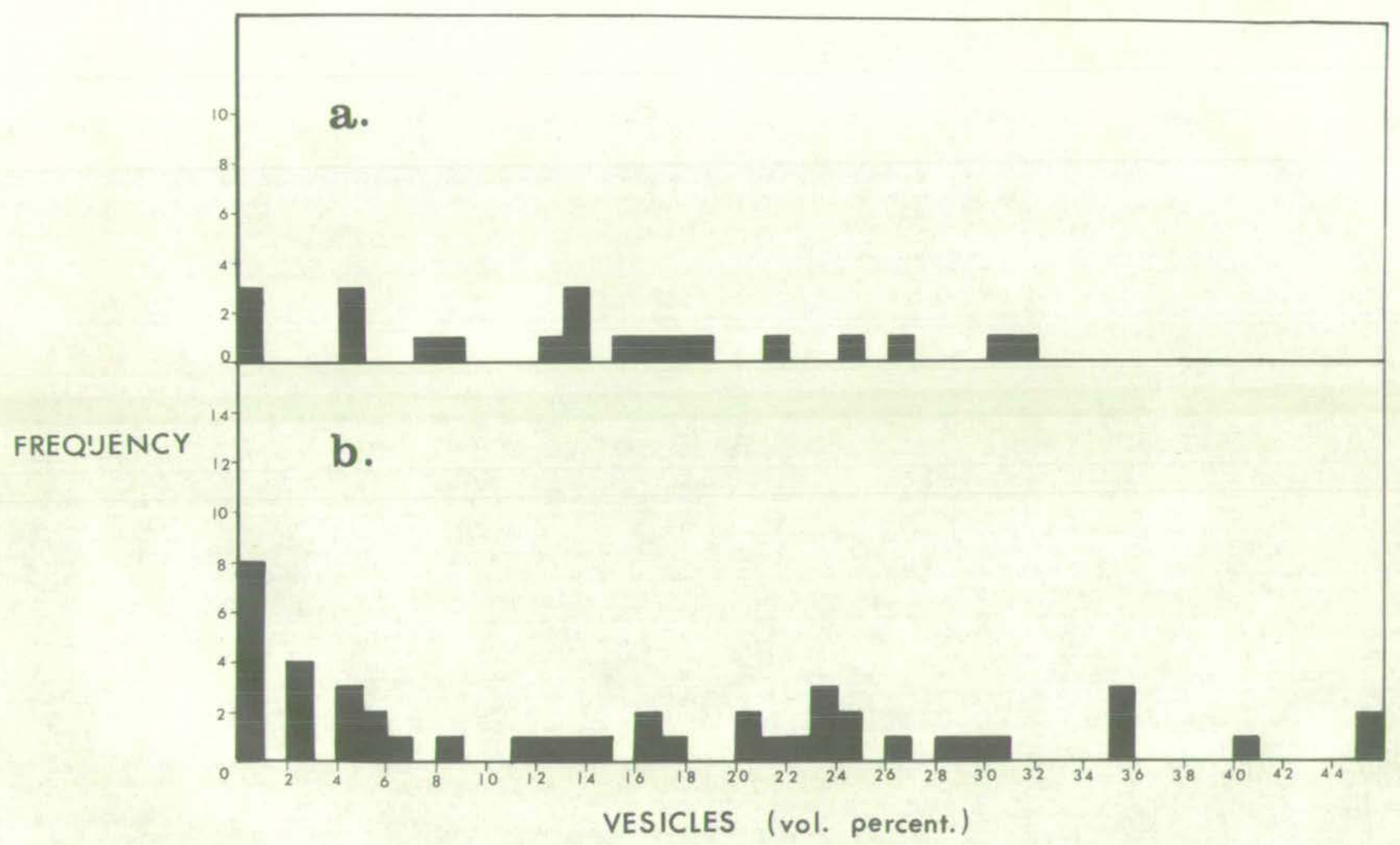


rocks (samples 105, 107, and 110, Table B-4) are petrographioally similar to the alkali basalt flows. Blocks of variolitic gabbro and layered dolerite (samples 42 and 44 , Table $B-4$ ) are strewa over the caldera floor near Chahale pit crater. Although it is questionable whether these rocks are truly intrusive, possibly being derived from the central parts of thick caldera-filling flows, they are classed as such in this study because of their distinctive gabbroic texture.

A single gabbrolo inclusion, about $3 \mathrm{om}$ in diameter, was found in a historic oceanite flow near Itsoundzou, on the southwest slopes of Kartale. This was not examined in thin section, but it appears to be much richer in mafic minerals than those blocks found in the ealdera.

No intrusive rooks were found in situ on La Grille, but one very coarse-grained inclusion was found in lava fragments from the Dinde tuff cone. This differs from the gabbrolo blocks of Kartala, however, in that it consists of euhedral olivine phenocrysts set in a holocrystalline fluidal groundmass of plagioclase, titanaugite, magnetite, and calcite, with minor brown alteration along the cracks and vesicles. These features suggest that this specimen was in fact derived from a coarse-grained lava flow.

3.3.3. Ultramafic inclusions

Ultramafic inolusions were found in the lavas of Kartala in only two locations, although searched for throughout the field studies. A specimen of only one of these could be obtained, and it was too small for reliable separation and chemical analysis. However, thin sections 
show it to be dunitic, consisting entirely of equigranular olivine erystals.

In contrast, ultramafic inclusions are common in the lava flows and pyroclastic cones sampled on La Grille, and one can see from Table B-2 that these occur in eleven of the nineteen samples analysed. In one particular flow, at Goulaivoini (Fig. 5), they make up possibly $20 \%$ of the rock, and an inclusion-free hand specimen is difficult to obtain. Wehrlite is the most abundant rock type, but dunite and Iherzolite are also found. Along with the variable amounts of olivine, pale green diopside, and orthopyroxene, these in clusions generally contain minor amounts of reddish-brown spinel, some in symplectic intergrowth with orthopyroxene. (Pide a) . Granular aggregates and veins of euhedral olivine and diopside are commonly seen along the margins and cleavage of the orthopyroxene crystals. At contacts with the surrounding lava, orthopyroxenes of the inclusions are surrounded by polysynthetically twinned clinopyroxene, a feature noted above for isolated orthopyroxene crystals.

\subsubsection{Sandstone inclusions}

Sandstone inclusions were found in the lavas on the western slopes of La Grille, and also in the basanitic inclusions of the Dinde turf cone (Plate 20), but none have been detected in the lavas of Kartala. They are white, friable, and always less than $1 \mathrm{~cm}$. across. Although they were too small for thin-sectioning, quartz, microcline, and albite were identified by $\mathrm{X}$-ray diffraction and confirmed by oil immersion techniques. These inclusions may thus be described as arkosio, similar to those of Moheli and Anjouan. 
3.4. SUMMARY

The lavas of each volcano, Kartala and La Grille, are distinct and conveniently separable on the basis of normative nepheline content. The Kartala lavas are classed as alkali basaltic, with an average of $3.7 \%$ normative nepheline. The La Grille lavas are classed as basanitic, with an average of $11.5 \%$ normative nepheline. The Kartala lavas contain olivine, clinopyroxene, and in some instances plagioclase, as phenocrysts. The La Grille lavas invariably contain olivine phenocrysts, and rarely subordinate amounts of titanaugite as phenocrysts.

The Badjini lavas are petrographically allied to both the Kartala and La Grille lavas.

Ultramaric inclusions are rare in Kartala and Badjini lavas, but are abundant in some of those of La Grille. Sandstone inclusions are found only in the La Grille lavas. 


\section{MTNERADOGY}

\subsection{MINERALOGY OF THE KARTALA LAVAS}

4.1.1. Introduction

The compositions of fifteen olivines, twelve clinopyroxenes, and fifteen feldspars have been estimated, using optical, X-ray diffraction, X-ray fluorescence, and electron microprobe methods, as described in Appendix A. Because of the large amounts of data involved, the microprobe analyses are only summarized in this chapter, and are presented in detail in Appendix $\mathrm{E}$. 4.1.2. Olivine

The olivine phenocrysts of Kartala, with the exception of those In the feldspar-phyric basalt (No. 30), are within the composition limits Fo-80 to Fo- 87 (Tables 4 and 5). In contrast, olivine from the alkali dolerite (No. 44) is more fayalitic, and zoned from Fo-57 to Fo-32, although the bulk chemistry of the rock is similar to that of the lavas. The groundmass olivines are more fayalitic than the phenocrysts, ranging from Fo- 80 to Fo- 65 in the basalts and Fo- 38 in the alkali dolerite. Nelther the groundmass nor phenocryst olivines show any obvious correlation with the bulk composition of their host rocks. 4.1.3. Clinopyroxene

All analysed clinopyroxenes in the lavas can be described as augites, with an average composition of $\mathrm{Ca}_{42} \mathrm{Mg}_{4} 8 \mathrm{Fe}_{10}$ indicated by $X$-ray fluorescence analysis of separated phenocrysts (Table 6). 


\section{Table 4.}

Chemical composition of Kartala olivines

\begin{tabular}{|c|c|c|c|}
\hline wt. $\%$ & 18 & 19 & 21 \\
\hline $\mathrm{SiO}_{2}$ & $39 \cdot 08$ & $39 \cdot 77$ & $39 \cdot 27$ \\
\hline $\mathrm{TiO}_{2}$ & $\cdot 07$ & .07 & .08 \\
\hline $\mathrm{Al}_{2} \mathrm{O}_{3}$ & $\cdot 48$ & .53 & $\cdot 48$ \\
\hline $\mathrm{Fe}_{2} \mathrm{O}_{3}$ & 1.69 & $1 \cdot 16$ & $2 \cdot 12$ \\
\hline $\mathrm{Cr}_{2} \mathrm{O}_{3}$ & $\cdot 20$ & $\cdot 20$ & $\cdot 15$ \\
\hline $\mathrm{FeO}$ & $13 \cdot 04$ & $13 \cdot 21$ & $13 \cdot 48$ \\
\hline Mno & $\cdot 22$ & $\cdot 22$ & $\cdot 24$ \\
\hline $\mathrm{MgO}$ & $43 \cdot 72$ & $44 \cdot 41$ & $43 \cdot 18$ \\
\hline NiO & $\cdot 22$ & .23 & $\cdot 21$ \\
\hline $\mathrm{CaO}$ & $\cdot 48$ & .57 & $\cdot 48$ \\
\hline $\mathrm{Na}_{2} \mathrm{O}$ & .01 & .00 & .01 \\
\hline $\mathrm{K}_{2} \mathrm{O}$ & .01 & .01 & .00 \\
\hline $\mathrm{H}_{2} \mathrm{O}$ & $\cdot 21$ & .10 & .09 \\
\hline $\mathrm{P}_{2} \mathrm{O}_{5}$ & .02 & .02 & .01 \\
\hline Total & $99 \cdot 45$ & $100 \cdot 72$ & $99 \cdot 79$ \\
\hline
\end{tabular}

$\mathrm{ppm}$

Cu

22

23

33

Zn

102

103

117

$\mathrm{Zr}$

17

17

17

Fo mol \%

$84 \cdot 4$

$84 \cdot 7$

$83 \cdot 3$ 
Table 5.

Composition of Kartala olivines

Separated

\section{Rock}

No.

1

2

3

8

18

$19^{*}$

21

22

26

31

41

Mean

16

30

44

XRF

$-$

-

$-$

$-$

$84 \cdot 4$

$84 \cdot 7$

$83 \cdot 3$

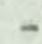
Bulk Phenocrysts

87

$82 \cdot 8$

81

87

-

$86 \cdot 4$

$86 \cdot 0$

86

84.

84.

84
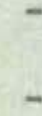

$-$ \begin{tabular}{l}
$-\quad 80.0$ \\
\hline
\end{tabular}

Microprobe Analyses

\section{Phenocrysts}

Core RIM

83.9

$77 \cdot 3$

$80 \cdot 9$

$77 \cdot 7$

$80 \cdot 4$

81

75

$\frac{84 \cdot 7}{84 \cdot 2}$
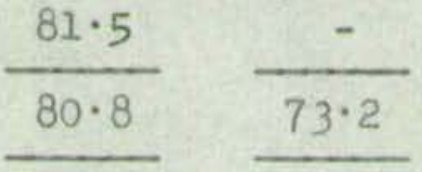

90

$69 \cdot 8$

$66 \cdot 2$

$66 \cdot 1$

67

$57 \cdot 5$

$38 \cdot 4$

59

*

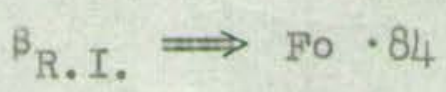

* Normative mean includes all Kartala lavas.

All data expressed in mol \% Fo.

$X R F=X$-ray fluorescence

$X R D=X$-ray diffraction 
Table 6

$\underline{X-r a y}$ fluorescence analysis of Kartala clinopyroxenes

\begin{tabular}{|c|c|c|c|c|c|c|c|c|}
\hline Wt. $\%$ & 1 & 13 & 18 & 21 & 23 & 30 & 31 & 42 \\
\hline $\mathrm{SiO}_{2}$ & $51 \cdot 19$ & $50 \cdot 84$ & $50 \cdot 87$ & $50 \cdot 46$ & $49 \cdot 41$ & $48 \cdot 41$ & $51 \cdot 18$ & $44 \cdot 99$ \\
\hline $\mathrm{TiO}_{2}$ & 1.08 & 0.88 & 0.71 & 0.76 & $1 \cdot 11$ & $2 \cdot 24$ & 0.99 & 3.96 \\
\hline $\mathrm{Cr}_{2} \mathrm{O}_{3}$ & 0.27 & 0.44 & $0 \cdot 36$ & $0 \cdot 38$ & 0.41 & 0.05 & $0 \cdot 46$ & - \\
\hline $\mathrm{Al}_{2} \mathrm{O}_{3}$ & $4 \cdot 68$ & 3.99 & $2 \cdot 92$ & 3.67 & $4 \cdot 42$ & $6 \cdot 45$ & $4 \cdot 47$ & $4 \cdot 89$ \\
\hline $\mathrm{Fe}_{2} \mathrm{O}_{3}$ & 0.47 & $1 \cdot 30$ & 0.53 & 0.92 & 0.60 & $2 \cdot 30$ & 0.07 & $2 \cdot 21$ \\
\hline $\mathrm{FeO}$ & $5 \cdot 55$ & $3 \cdot 85$ & $5 \cdot 58$ & 4.92 & $6 \cdot 20$ & $5 \cdot 82$ & $5 \cdot 47$ & $14 \cdot 70$ \\
\hline Mno & 0.11 & 0.10 & 0.11 & 0.10 & 0.11 & 0.15 & 0.07 & 0.18 \\
\hline $\mathrm{MgO}$ & $15 \cdot 49$ & $15 \cdot 70$ & $19 \cdot 96$ & $17 \cdot 41$ & $16 \cdot 50$ & $12 \cdot 31$ & $15 \cdot 64$ & $10 \cdot 02$ \\
\hline $\mathrm{CaO}$ & $20 \cdot 81$ & $21 \cdot 63$ & $19 \cdot 49$ & 20.07 & $19 \cdot 91$ & 21.03 & $21 \cdot 76$ & $17 \cdot 62$ \\
\hline $\mathrm{Na}_{2} \mathrm{O}$ & 0.55 & 0.34 & 0.26 & 0.49 & 0.45 & 0.61 & $0 \cdot 38$ & 0.97 \\
\hline $\mathrm{K}_{2} \mathrm{O}$ & 0.11 & 0.02 & 0.01 & 0.03 & 0.04 & 0.05 & 0.04 & 0.32 \\
\hline $\mathrm{P}_{2} \mathrm{O}_{5}$ & 0.11 & 0.10 & 0.08 & 0.08 & 0.13 & 0.10 & 0.09 & 0.37 \\
\hline $\mathrm{H}_{2} \mathrm{O}$ & 0.15 & 0.09 & 0.13 & 0.20 & 0.14 & 0.14 & 0.20 & 0.34 \\
\hline Total & $99 \cdot 77$ & $99 \cdot 28$ & $101 \cdot 01$ & $99 \cdot 49$ & $00 \cdot 16$ & $99 \cdot 66$ & $101 \cdot 42$ & $100 \cdot 57$ \\
\hline
\end{tabular}

[contd. 
Table 6 [Contd.]

\begin{tabular}{|c|c|c|c|c|c|c|c|c|}
\hline wt.\% & 1 & 13 & 18 & 21 & 23 & 30 & 31 & 42 \\
\hline Or & 0.65 & 0.12 & 0.06 & 0.18 & 0.24 & 0.30 & 0.24 & 1.89 \\
\hline $\mathrm{Ab}$ & $4 \cdot 35$ & $2 \cdot 91$ & $2 \cdot 19$ & $4 \cdot 10$ & $2 \cdot 61$ & $3 \cdot 21$ & $1 \cdot 72$ & 3.69 \\
\hline An & $9 \cdot 96$ & $9 \cdot 42$ & $6 \cdot 74$ & $7 \cdot 81$ & 10.03 & $14 \cdot 79$ & $10 \cdot 36$ & 8.02 \\
\hline $\mathrm{Ne}$ & 0.16 & - & - & 0.05 & 0.67 & 1.07 & 0.81 & $2 \cdot 44$ \\
\hline D1 & $73 \cdot 39$ & 77.68 & $70 \cdot 43$ & 73.04 & $70 \cdot 75$ & $70 \cdot 81$ & $76 \cdot 99$ & $62 \cdot 94$ \\
\hline Hy & - & 1.57 & $1 \cdot 88$ & - & - & - & - & - \\
\hline OI & $8 \cdot 50$ & $4 \cdot 46$ & $16 \cdot 41$ & $11 \cdot 82$ & $12 \cdot 37$ & 1.95 & $7 \cdot 77$ & $9 \cdot 45$ \\
\hline Mt & 0.68 & 1.91 & 0.76 & $1 \cdot 35$ & 0.88 & $3 \cdot 35$ & 0.01 & $3 \cdot 20$ \\
\hline Ilm & 2.05 & 1.69 & $1 \cdot 34$ & $1 \cdot 46$ & $2 \cdot 13$ & $4 \cdot 28$ & $1 \cdot 88$ & $7 \cdot 50$ \\
\hline $\mathrm{Ap}$ & $0 \cdot 26$ & 0.24 & 0.19 & 0.19 & 0.31 & 0.24 & 0.21 & 0.87 \\
\hline \multicolumn{9}{|l|}{ ppm } \\
\hline $\mathrm{Cu}$ & 18 & 13 & 16 & 48 & 27 & 10 & 22 & 83 \\
\hline $\mathrm{Sr}$ & 74 & 50 & 40 & 92 & 97 & 201 & 53 & 109 \\
\hline $\mathrm{Ba}$ & 45 & 72 & 50 & - & 50 & 100 & 50 & 40 \\
\hline $\mathrm{Zn}$ & 44 & 36 & 45 & 51 & 45 & 45 & 41 & 103 \\
\hline $\mathrm{Zr}$ & 67 & 44 & 35 & 40 & 62 & 227 & 55 & 226 \\
\hline $\mathrm{Cr}$ & 1850 & 3020 & 2430 & 2610 & 2820 & 350 & 3140 & 20 \\
\hline $\mathrm{Ni}$ & 360 & 200 & 630 & 390 & 245 & 80 & 240 & 22 \\
\hline $\mathrm{Ca}$ & $43 \cdot 79$ & $45 \cdot 51$ & $37 \cdot 29$ & $40 \cdot 96$ & $41 \cdot 20$ & $47 \cdot 24$ & $45 \cdot 32$ & $47 \cdot 62$ \\
\hline $\mathrm{Mg}$ & $46 \cdot 15$ & $46 \cdot 24$ & -53.48 & $49 \cdot 77$ & $47 \cdot 80$ & 38.69 & $45 \cdot 60$ & $27 \cdot 00$ \\
\hline$\sum \mathrm{Fe}^{*}$ & 10.05 & $8 \cdot 38$ & $9 \cdot 22$ & $9 \cdot 27$ & 11.00 & $14 \cdot 07$ & $9 \cdot 08$ & $25 \cdot 38$ \\
\hline
\end{tabular}


The gabbroic augite (No. 42) is richer in iron, at $\mathrm{Ca}_{48} \mathrm{Mg}_{27} \mathrm{Fe}_{25}$, and that of the feldspar-phyric basalt (No. 30) lles between these extremes at $\mathrm{Ca}_{47} \mathrm{Mg}_{39} \mathrm{Fe}_{14}$. A plot of these compositions in the "pyroxene quadrilateral" (i.e. the mol. proportions of $\mathrm{Ca}-\mathrm{Mg}-\mathrm{Fe}^{++}$) shows them to be less calcic than the augites from other alkaline basaltic magmes (Fig. 11a). This almost certainly results from contamination with olivine, which is also suggested by the high Ni concentrations and the substantial content of normative ol (Table 6). The electron microprobe data for Kartala augites (Table 7) have been selected from the or Iginal data (Appendix $E$ ) to show the most iron-poor cores and lron-rich rims of phenocrysts and the most iron-rich groundmass compositions. The average phenocryst composition calculated from these data, $\mathrm{Ca}_{45^{\mathrm{Mg}}} 6^{\mathrm{Fe}}$, is more diopsidic than that indicated by $X$-ray fluorescence analyses, further supporting the suggestion that the latter may reflect slight olivine contamination. There is a general trend of iron-enrichment from the cores to rims of phenocrysts which continues into the groundmass augites (Fig. 1Ib). The doleritic augite (No. 44) appears to resemble tholeiltic augites in its low calcium content (Fig. 11b), although the bulk rock contains $6 \%$ normative nepheline.

The composition of Kartala augites, like that of the olivines, shows no apparent correlation with bulk rock composition, implying a lack of equilibrium between crystals and melt, although only very minor resorption textures are seen in thin-section (Chapter 3). To obtain oome idea of the relations between the minerals themselves, they have been plotted in the pyroxene quadrilateral, with tie-lines 


\section{Table 7}

Electron microprobe analysis of Kartala augites

\begin{tabular}{|c|c|c|c|c|c|c|c|c|c|}
\hline & \multicolumn{3}{|c|}{ CORB } & \multicolumn{3}{|c|}{ RIM } & \multicolumn{3}{|c|}{ GROUNDMASS } \\
\hline & $\mathrm{Ca}$ & $\mathrm{Mg}$ & $\sum F \theta$ & $\mathrm{Ca}$ & $\mathrm{Mg}$ & $\sum \mathrm{Fe}$ & $\mathrm{Ca}$ & $\mathrm{Mg}$ & $\sum \mathrm{Fe}_{\theta}$ \\
\hline 1 & $44 \cdot 4$ & $48 \cdot 9$ & $6 \cdot 7$ & $45 \cdot 4$ & $41 \cdot 8$ & $12 \cdot 8$ & $46 \cdot 1$ & $41 \cdot 4$ & $12 \cdot 5$ \\
\hline 2 & $44 \cdot 4$ & 48.9 & $6 \cdot 7$ & $44 \cdot 8$ & $44 \cdot 8$ & $10 \cdot 4$ & $52 \cdot 8$ & $26 \cdot 4$ & $20 \cdot 6$ \\
\hline 26 & $47 \cdot 1$ & $44 \cdot 7$ & $8 \cdot 2$ & $46 \cdot 5$ & $44 \cdot 1$ & $9 \cdot 5$ & $44 \cdot 2$ & $44 \cdot 2$ & 23.5 \\
\hline 30 & $47 \cdot 5$ & $42 \cdot 6$ & $10 \cdot 0$ & $44 \cdot 4$ & $42 \cdot 1$ & 13.5 & $48 \cdot 3$ & 38.0 & $13 \cdot 8$ \\
\hline 31 & $45 \cdot 4$ & $46 \cdot 9$ & $7 \cdot 7$ & 44.5 & $46 \cdot 0$ & $9 \cdot 6$ & $43 \cdot 7$ & $47 \cdot 0$ & $8 \cdot 3$ \\
\hline 41 & $48 \cdot 3$ & $45 \cdot 4$ & $5 \cdot 9$ & $43 \cdot 0$ & $47 \cdot 7$ & $9 \cdot 3$ & $42 \cdot 4$ & $45 \cdot 8$ & $11 \cdot 8$ \\
\hline$* 44$ & $40 \cdot 3$ & $50 \cdot 7$ & $9 \cdot 0$ & $36 \cdot 3$ & $43 \cdot 7$ & $20 \cdot 0$ & - & - & - \\
\hline
\end{tabular}

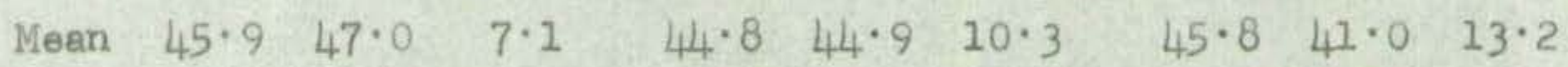

$\sum \mathrm{Fe}_{\theta}=\mathrm{Fe}^{+2}+\mathrm{Fe}^{+3}+\mathrm{Mn}^{+2}$

* excluded from calculation of the mean. 
Fig. 11.

Plot of Ca:Mg: $\sum \mathrm{Fe}$ ratios of Kartala elinopyroxenes

$$
\begin{aligned}
& \left(\Sigma \mathrm{Fe}=\mathrm{Fe} e^{+2}+\mathrm{Fe}^{+3}+\mathrm{Nn}\right) \\
& \text { a. X-ray fluorescence analyses } \\
& \bullet=\text { data } \\
& 1=\text { Black Jack sill } \\
& 2=\text { Garbh Eilean sill } \\
& 3=\text { Skaergard Intrusion }
\end{aligned}
$$

b. Electron microprobe analyses

$$
\begin{aligned}
& \nabla=\text { core } \\
& \nabla=\text { groundmass }
\end{aligned}
$$

(oross-hatched area in insert shows area of main diagram) 

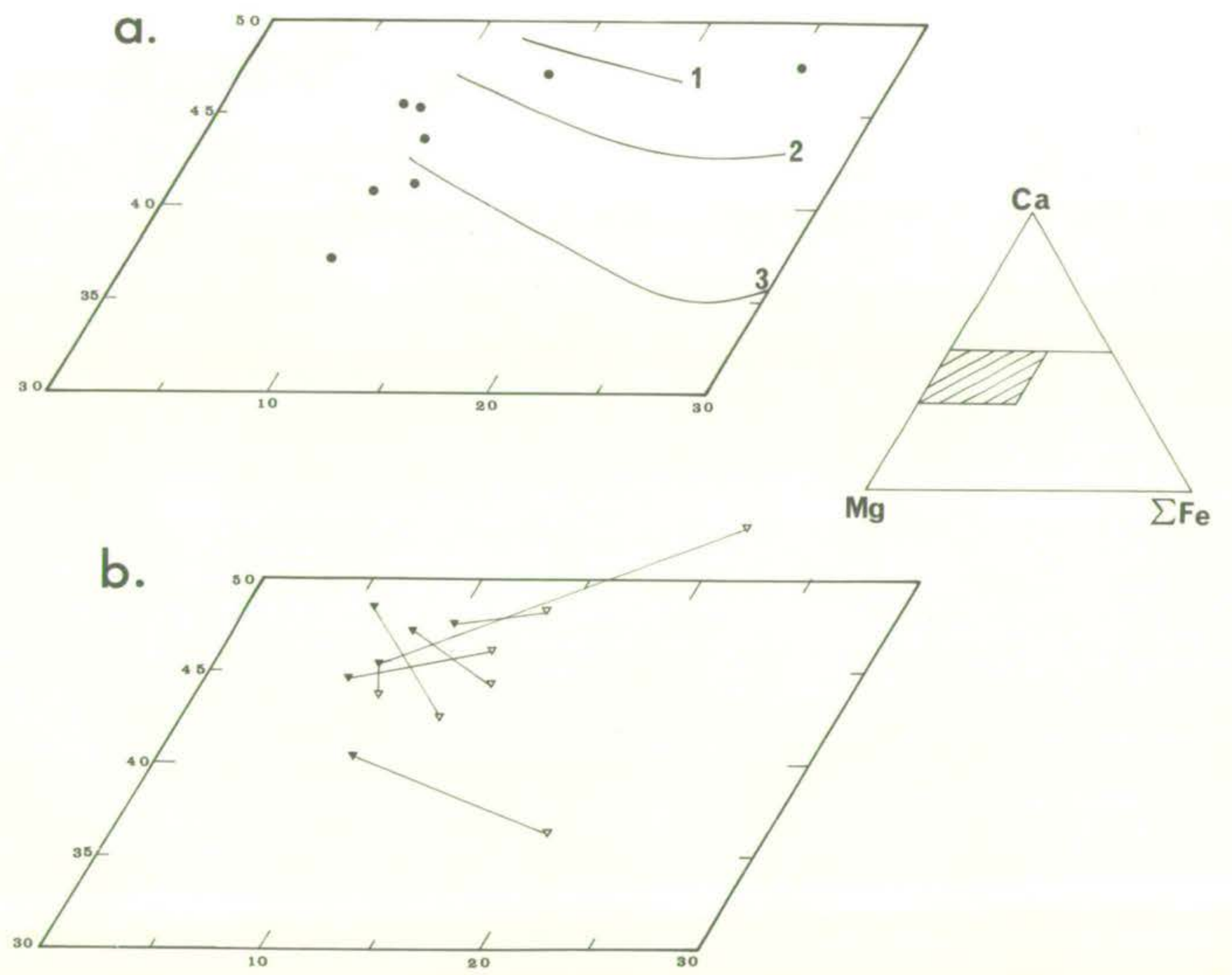
drawn between coexisting olivine and augite phenocrysts (Fig. 12a). The consistent orientation of these tie-1ines suggests that these phases could have crystallized in equilibrium with one another. It is uncertain, however, just what should be the orientation of equilibrium tie-lines between olivine and augite since, for example, those of the Garbh Eilean sill (Murray, 1954), the Black Jack sill (Wilkinson, 1956), and the Nandewar voloano (Abbott, 1969) all show tie-lines of different orientation (Fig. 12b). If the Kartala olivine and augite are in equilibrium with one another but not with the liquid, as these data suggest, one must suppose that they remained together during movement from the source of orystallization. 4.1.4. Plagioclase

As plagioclase phenocrysts occur in only six of the analysed Kartala lavas (Chapter 3; Appendix B), they were of relatively minor interest to the present study. However, analyses of plagioclase from one lava flow (No. 30) and one gabbrioc block (No. 42) are given in Table 8 .

The anorthite contents of microphenocrysts and groundmass feldspars from a range of Kartala lavas, as detemined by optioal methods (Appendix A), are given in Table 9. These show slight variation about a mean of An-65 for the microphenocrysts and An-54 for the groundmass feldspars, corresponding with the average normative composition of An-54. 4.1.5. Other Minersls

Opaque oxides are the only visible orystaline phase, other than ollvine, augite, and plagioclase, in the lavas. These consist 
Fig. 12 .

$$
\begin{aligned}
& \text { Augite - olivine tie-lines in } \\
& \text { Ca:Mg: } \sum \text { Fe diagram. } \\
& \text { A. Kartala data } \\
& \text { b. Data from other studies } \\
& \nabla=(\text { Murray, 1954) } \\
& -=(\text { Wilkinson, 1956) } \\
& =\quad=(\text { Abbott, 1969) }
\end{aligned}
$$

Aress of diagram shown in insert. 

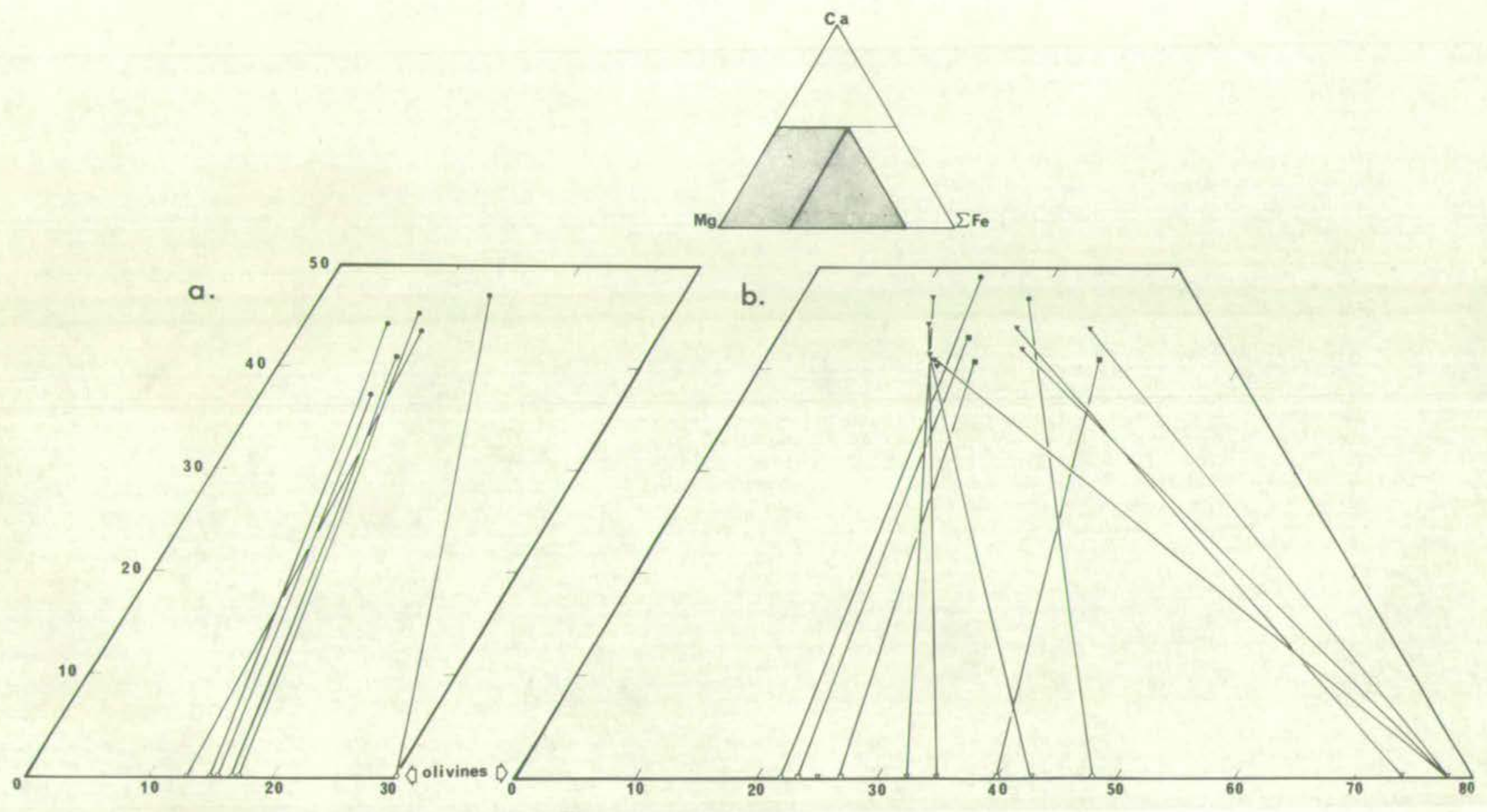
primarily of magnetite, generally homogeneous but rarely with hematite lamellae, occurring as octahedral miorophenocrysts or skeletal groundmass crystals. Less commonly, tabular 1lmenitehematite intergrowths are seen, as well as very scarce specks of sulphide, probably pyrite.

Nepheline has been detected in some of the coarser-grained lavas (e.g. No. 22, Tables $\mathrm{B}-1$ and $\mathrm{C}-1$ ) by X-ray diffraction, but it is not Identifiable under the microscope. It does not occur in the more glassy lavas. As shown in Chapter 3, the yellow-brown groundmass glass of the lavas has refractive indices between 1.606 and 1.610 , corresponding to 47.0 and $46 \cdot 4 \% \mathrm{SiO}_{2}$ respectively (using the curves for Gough Island given by Yoder and Tilley, 1962, Fig. 9).

4.2. MINERALOGY OP THE LA GRILLIE LAVAS

4.2.1. 011vine phenocrysts

As described in Chapter 3, olivine is the dominant phenocryst phase in all the analysed lavas of La Grille, and it is the only phenocryst phase in $70 \%$ of them. The forsterite contents of olivine phenocryats from eight of the La Grille lavas and from one Therzolite inclusion are given in Table 10. An outstanding feature of these olivines is their high forsterite content, averaging Fo-90. These are more forsteritic than those of Kartala lavas, at Fo-84, and even the Therzolite olivine, at Fo-86. In fact, olivines of this composition are only very rarely found in lavas (cf. Brown, 1967). Although one can only tentatively accept these compositions until more accurate data are available, the consistency of the two methods of 
Table 8

Chemical composition of Kartala plagioclases

wt. $\%$

$\mathrm{SiO}_{2}$

$\mathrm{TiO}_{2}$

$\mathrm{Al}_{2} \mathrm{O}_{3}$

$\mathrm{Fe}_{2} \mathrm{O}_{3}$ *

Mno

$\mathrm{MgO}$

$\mathrm{CaO}$

$\mathrm{Na}_{2} \mathrm{O}$

$\mathrm{K}_{2} \mathrm{O}$

$\mathrm{P}_{2} \mathrm{O}_{5}$

$\mathrm{H}_{2} \mathrm{O}$

Total

Q

Cor

Or:

$\mathrm{Ab}$

An

Ne

Di

Hy

01

IIm

Ap

$\mathrm{Rb}$
$\mathrm{Cu}$
$\mathrm{Sr}$
$\mathrm{Ba}$
$\mathrm{Zn}$
$\mathrm{Zr}$
30

$52 \cdot 76$

0.17

0.67

0.00

0.45

$12 \cdot 41$

3.91

0.46

0.08

0.12

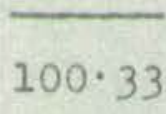

0.84

0.05

2.71

33.02

60.93

-

$-$

1.94

-

0.32

0.19
$29 \cdot 35$

42

$57 \cdot 93$

0.14

$24 \cdot 72$

1.00

0.00

0.04

$7 \cdot 26$

$6 \cdot 20$

$2 \cdot 34$

0.35

0.11

$100 \cdot 00$

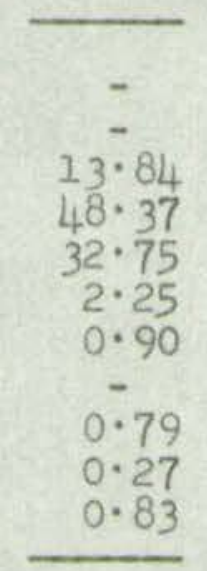

45

39

1120

770

535

-

$\begin{array}{llllll}2 \cdot 8 & 34 \cdot 2 & 63 & 14 \cdot 6 & 51 & 34 \cdot 4\end{array}$

- $\mathrm{Fe}_{2} \mathrm{O}_{3}=$ total iron as $\mathrm{Fe}_{2} \mathrm{O}_{3}$. 
Table 9

Anorthite contents ${ }^{*}$ of Kartala plagioclases

\begin{tabular}{cccc}
\hline Rock No. & Microphenocrysts & Groundmass & Normative \\
\hline 1 & - & 48 & 54 \\
3 & 72 & 55 & - \\
4 & 60 & - & 55 \\
5 & 65 & 55 & - \\
13 & - & 55 & 57 \\
17 & $60-65$ & $44-52$ & 57 \\
22 & - & 58 & 52 \\
25 & 60 & - & 49 \\
26 & - & 55 & 53 \\
28 & 68 & 55 & 52 \\
32 & - & 55 & 52 \\
45 & - & 54 & - \\
50 & - & 58 & - \\
\hline Mean & 65 & 54 & 54 \\
\hline
\end{tabular}

* Optically determined (see Appendix A). 
determination, already conflrmed for the Kartala lavas, suggests that they are rellable. Some further support for this assumption may be derived from the bulk rook nomative olivine compositions, Whioh at an average of Fo-79 are more basic than the Kartala normative olivines with an average of Fo-70.

4.2.2. Clinopyroxene phenocrysts

None of the scarce clinopyroxenes of La Grille lavas were chemically analysed, but their optical properties suggested they are titanaugites, some times showing pale green cores, possibly diopsidic. The possibility thet these clinopyroxenes are xenocrysts derived from the Iherzolites cannot be discounted.

Pale green chrome diopside was separated from a Iherzolite inclusion (No. 35, Tables $\mathrm{B}-3$ and $\mathrm{C}-3$ ), and its composition is given in Table 11.

4.2.3. Groundmass minerals

The groundmass of La Grille lavas consists of forsteritic olivine, augite, opaque oxides, plagioclase and apatite in some cases, nepheline in the coarser rocks, and brown glass in most. Groundmass augites are distinctly brown in colour, as compared to the grey-purple colour of the phenocrysts. An outstanding example of these are found in the basanite No. 10 (Tables B-2 and C-2) where there is an abrupt deepening of the brown colour around the margins of vesicles and in residual liquid which lines the vesicles (of. Smith, 1968).

The opaque minerals in La Grille lavas are magnetite, sometimes 
Table 10

Forsterite contents of La Grille olivines

\begin{tabular}{|c|c|c|c|c|}
\hline Rock No. & $\begin{array}{l}\text { XRD } \\
\pm 4 \%\end{array}$ & $\begin{array}{l}\beta R I \\
\pm 2 \%\end{array}$ & Normative & \\
\hline 9 & $90 \cdot 9$ & 88 & 77 & \\
\hline 36 & $92 \cdot 3$ & 88 & 84 & \\
\hline $37(2)$ & $90 \cdot 6$ & 90 & 85 & \\
\hline 52 & - & 83 & 83 & \\
\hline 53 & - & 84 & 80 & \\
\hline 54 & $94 \cdot 1$ & 88 & 76 & \\
\hline 165 & - & 88 & 88 & \\
\hline 171 & - & 87 & 82 & \\
\hline Mean & 92.0 & 87 & $79^{*}$ & \\
\hline & & & & Probe \\
\hline 35 & $84 \cdot 7$ & 86 & 90 & $86 \cdot 2$ \\
\hline
\end{tabular}

* Normative mean $=$ mean of all 19 La Grille lavas. 
Table 11

Chemical composition of clinopyroxene from Therzolite (No. 35)

\begin{tabular}{|c|c|}
\hline $\mathrm{SiO}_{2}$ & 52.53 \\
\hline $\mathrm{TiO}_{2}$ & 0.59 \\
\hline $\mathrm{Al}_{2}, \mathrm{O}_{3}$ & 4.53 \\
\hline $\mathrm{Fe}_{2} \mathrm{O}_{3}$ & 0.03 \\
\hline $\mathrm{Cr}_{2} \mathrm{O}_{3}$ & 1.06 \\
\hline $\mathrm{FeO}$ & 3.71 \\
\hline Mino & 0.11 \\
\hline MgO & 18.07 \\
\hline $\mathrm{CaO}$ & $18 \cdot 21$ \\
\hline $\mathrm{Na}_{2} \mathrm{O}$ & 0.25 \\
\hline $\mathrm{K}_{2} \mathrm{O}$ & 0.02 \\
\hline $\mathrm{H}_{2} \mathrm{O}$ & 0.19 \\
\hline $\mathrm{P}_{2} \mathrm{O}_{5}$ & 0.09 \\
\hline Total & 99.80 \\
\hline \multicolumn{2}{|l|}{$\mathrm{ppm}$} \\
\hline $\mathrm{Cu}$ & 42 \\
\hline $\mathrm{Sr}$ & 138 \\
\hline $\mathrm{Zn}$ & 31 \\
\hline $\mathrm{Zr}$ & 72 \\
\hline $\mathrm{Cr}$ & 7246 \\
\hline $\mathrm{N} 1$ & 580 \\
\hline $\mathrm{Ca}$ & $39 \cdot 2$ \\
\hline $\mathrm{Mg}$ & $54 \cdot 4$ \\
\hline$\sum F \theta$ & $6 \cdot 4$ \\
\hline
\end{tabular}


with hematite lamellae, or ilmenite-hematite intergrowths, all apparently similar to those of Kartala lavas. The groundmass plagioclase was generally too small for reliable estimates of composition, but determinations on three rocks gave an average of An-54, similar to those of Kartala. Nephelino was identifled by X-ray diffraction, but although apparently visible mioroscopically it could not be reliably identified.

4.3. SUMMARY

The Kartala lavas are made up of forsteritic olivine, diopsidic augite, and scarce calolo plagioclage phenocrysts in a commonly glassy matrix of sodic labradorite, olivine, augite, magnetite, and rare nepheline. The ta Grille lavas consist of forsteritic olivine and scarce titanaugite phenocrysts in a glassy groundmass of olivine, augite, nepheline, magnetite, sometimes plagioolase, and very rarely apatite. 


\section{PETROCHEMISTRY}

5.1. INTRODUCTION

Eighty new chemical analyses and C.I.P.W. norms of rocks from Grande Comore are presented in Appendix C. The analysed rocks have the following distribution:

$\begin{array}{lr}\text { Kartala lavas } & 46 \\ \text { La Grille lavas } & 19 \\ \text { Badjini lavas } & 5 \\ \text { Kartala Intrusive rocks } & 5 \\ \text { Other miscellaneous rocks } & 5\end{array}$

The apparent bias of sampling towards Kartala lavas reflects the greater size of this volcano (cf. Figs. 3 and 5).

Rocks were chosen for analysis in order to maintain an even distribution over the whole island (see Fig. 5), and to cover as wide as possible a range of chemical variation. This variation was predicted to some extent from phenocryst content of the rocks, although a large number of aphyric rocks were analysed in order to detect any variation not predictable from petrography. No analysed lavas from Grande Comore show any significant indication of chemical weathering or other secondary alteration, except for No. $38 \mathrm{~A}$, which is excluded from any petrological interpretations.

The methods of chemical analysis are described in Appendix A. Chemical analyses of five rocks from Grande Comore were given by Lacroix (1922), and these are shown in Table 12, along with C.I.P.W. norms calculated in the present study. Because of differences in analytical methods, and the imprecise location of the rocks, 
Table 12

Chemical analyses of rocks from Grande Comore given by Lacroix (1922)

\begin{tabular}{|c|c|c|c|c|c|}
\hline wt $\%$ & 4 & 7 & 8 & 15 & 18 \\
\hline $\mathrm{SiO}_{2}$ & $48 \cdot 76$ & $47 \cdot 36$ & $46 \cdot 50$ & $45 \cdot 84$ & $42 \cdot 00$ \\
\hline $\mathrm{TiO}_{2}$ & $3 \cdot 16$ & $2 \cdot 87$ & $2 \cdot 29$ & 3.00 & 1.83 \\
\hline $\mathrm{Al}_{2} \mathrm{O}_{3}$ & $12 \cdot 31$ & $12 \cdot 50$ & $14 \cdot 66$ & $7 \cdot 45$ & $11 \cdot 04$ \\
\hline $\mathrm{Fe}_{2} \mathrm{O}_{3}$ & $2 \cdot 54$ & $2 \cdot 26$ & 3.69 & 1.66 & 3.94 \\
\hline $\mathrm{FeO}$ & 10.58 & $10 \cdot 51$ & $9 \cdot 32$ & $9 \cdot 64$ & $7 \cdot 71$ \\
\hline Mno & - & - & - & - & - \\
\hline $\mathrm{MgO}$ & $5 \cdot 43$ & 7.05 & $6 \cdot 04$ & $16 \cdot 76$ & $16 \cdot 38$ \\
\hline $\mathrm{CaO}$ & $12 \cdot 32$ & $13 \cdot 24$ & $12 \cdot 00$ & $12 \cdot 64$ & $12 \cdot 50$ \\
\hline $\mathrm{Na}_{2} \mathrm{O}$ & $3 \cdot 44$ & $2 \cdot 25$ & $3 \cdot 33$ & $1 \cdot 38$ & $2 \cdot 30$ \\
\hline $\mathrm{K}_{2} \mathrm{O}$ & $1 \cdot 27$ & $1 \cdot 37$ & $1 \cdot 38$ & .99 & 1.65 \\
\hline $\mathrm{P}_{2} \mathrm{O}_{5}$ & $\cdot 39$ & .44 & .41 & $\cdot 42$ & .53 \\
\hline $\mathrm{H}_{2} \mathrm{O}^{7}$ & $\cdot 11$ & .09 & $\cdot 16$ & $\cdot 32$ & $\cdot 37$ \\
\hline $\mathrm{H}_{2} \mathrm{O}^{-}$ & - & .18 & .10 & .10 & .04 \\
\hline Total & $100 \cdot 31$ & $100 \cdot 12$ & 99.88 & $100 \cdot 20$ & $100 \cdot 31$ \\
\hline Or & 749 & $8 \cdot 11$ & $8 \cdot 18$ & $5 \cdot 86$ & Lc. $7 \cdot 65$ \\
\hline $\mathrm{Ab}$ & $21 \cdot 54$ & $15 \cdot 52$ & $15 \cdot 84$ & 8.00 & Cs. 1.84 \\
\hline An & $14 \cdot 37$ & $19 \cdot 99$ & $21 \cdot 05$ & $11 \cdot 23$ & $14 \cdot 85$ \\
\hline $\mathrm{Ne}$ & 4.07 & 1.92 & $6 \cdot 74$ & 2.01 & $10 \cdot 64$ \\
\hline D1 & $36 \cdot 34$ & $35 \cdot 13$ & $29 \cdot 43$ & 38.98 & $29 \cdot 98$ \\
\hline 01 & $5 \cdot 62$ & $9 \cdot 56$ & 8.05 & $24 \cdot 80$ & $24 \cdot 58$ \\
\hline Mt & $3 \cdot 67$ & $3 \cdot 28$ & $5 \cdot 37$ & $2 \cdot 41$ & $5 \cdot 72$ \\
\hline $\mathrm{Ilm}$ & 5.99 & $5 \cdot 46$ & $4 \cdot 36$ & $5 \cdot 71$ & $3 \cdot 48$ \\
\hline $\mathrm{Ap}$ & .92 & 1.04 & .97 & 1.00 & $1 \cdot 26$ \\
\hline D.I. & 33.09 & $25 \cdot 55$ & $30 \cdot 76$ & $15 \cdot 87$ & $18 \cdot 29$ \\
\hline
\end{tabular}

D.I. = Differentlation index (Thornton and Tuttle, 1960).

4. "Basalte andesitique", 1918 eruption, Kartala (compact, sparse olivine phenocrysts).

7. "Basalte labradorique", Oussivo, Kartala voloano (corded vitreous flow).

8. "Basalte labradorique", 1860 eruption, Kartala (transitional to basanitoide).

15. Ankaramite, Iooni, Kartala (equally abundant olivine and augite phenocrysts).

18. "Ankaratrite limburgitic", Bangoi-Kouni, La Grille (Olivine rich in spinel, brown glass). 
these analyses are of limited value to the present study. They do, however, indicate the undersaturated nature of the Grande Comore lavas, and No. 18 (Table 12), with $1.84 \%$ normative lamite (cs), displays a degree of silica-undersaturation unmatched in any rooks analysed in the present study.

In the following description of the petrochemistry, the Kartala and La Grille lavas are compared and contrasted. Following a brief discussion of the other analysed rocks, a statistical comparison of the two groups of lavas is made by means of disoriminant function analysis.

\subsection{MAJOR ELEMENT CHEMISTRY OF THE LAVAS}

5.2.1. Introduction

The chemical characteristios of groups of related rocks are often represented by means or an average of a number of analyses. Averages, in general, can be misleading, however, as they give no information about the type of distribution, and they can be representative of a whole population only when its distribution is normal and when it has been representatively sampled. Averages of chemical analyses can be especially misleading, since each element has a characteristic distribution which may vary independently of the other elements. Although these drawbacks can be minimized by calculating separate averages for each rock type, this should be done only when the rook classiflcation has a chemical basis. This procedure cannot be followed in the present study because the rock classiflcation adopted is both petrographio and chemical. Because of these considerations it is felt that a clearer 
picture of the rock chemistry can be obtained by means of histograms.

5.2.2. Histograms

The chemical characteristics of lavas from Kartala and La

Grille are summarized in the form of histograms in Fig. 13. Also included in Fig. 13 are the distributions (scaled down to one tenth) of major elements in 414 "nepheline basalts" given by Manson (1967, Table XIII). Some general comments on these distributions are made below, and the reader is referred to particular histograms for more precise information and for comparison with the data of Manson.

1. The modes of $\mathrm{SiO}_{2}, \mathrm{PIO}_{2}$, and $\mathrm{Al}_{2} \mathrm{O}_{3}$ are generally lower in the La Grille lavas than in those of Kartala. Conversely, the modes of $\mathrm{CaO}, \mathrm{MgO}, \mathrm{P}_{2} \mathrm{O}_{5}, \mathrm{MnO}$, and $\mathrm{H}_{2} \mathrm{O}$ are higher in the La Grille than in the Kartala lavas. $\mathrm{K}_{2} \mathrm{O}, \mathrm{Na}_{2} \mathrm{O}, \mathrm{Fe}_{2} \mathrm{O}_{3}$, and FeO have essentially similar distributions in each group.

2. All distributions are closer to normal in La Grille than Kartala lavas. This is especially so for the important variable $\mathrm{MgO}$, which has a positively skewed distribution in Kartala lavas.

3. Distribution of the La Grille differentiation indioes (of Thornton and Tuttle, 1960) are nomal, with a mode at 20, while that of Kartala is negatively skewed with a mode at 33 . 5.2.3. Variation diagrams

An analysis of variance and correlation matrices for the La Grille and Kartala lavas are given in Appendix D, showing that the 
Fig. 13.

Histograms of major element distributions in (a) La Grille and (b) Kaptala lavas. St1ppled areas represent data of Manson (1967, Table XIII) scaled down to one tenth. 


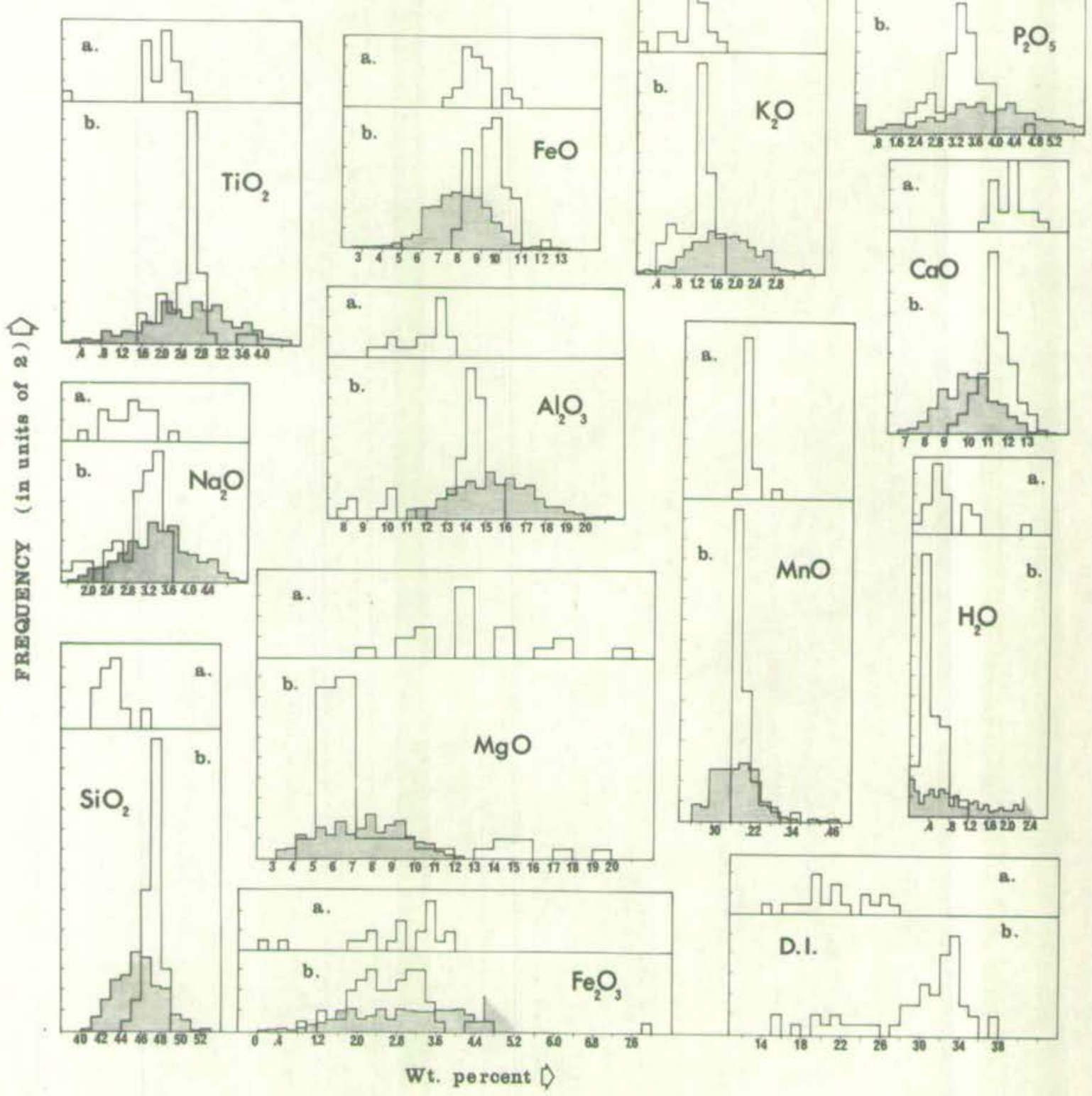


variance of $\mathrm{MgO}$ makes the largest single contribution to the total variance of both Kartala and La Grille analyses. Consequently, the overall chemical variation is best illustrated by means of the MgO variation diagrams, as shown in Figs. 14 and 15 . It can be seen from Fig. 14 that Kartala lavas with more than about $7.0 \%$ MgO form a linear trend which intersects the olivine-augite tie-line very olose to a point representing the average olivine/augite ratio of phenocrysts in these lavas. The Kartala lavas with less than $7.0 \% \mathrm{MgO}$ show a less clearly defined trend which extends towards the composition of augite phenocrysts in the lavas.

Variation trends for the La Grille lavas (Fig. 15) are much more poorly defined than those of Kartala, with cloudy distributions for most elements, as one would expect from the correlation coefficients given in Appendix D. As olivine is the only phenocryst phase In these lavas, control lines have been drawn from olivine through the clouds of points (Fig. 15). However, the major axis of any cloud of points is not parallel to any olivine control line. Other relations between these two groups of lavas are illustrated in two commonly used variation diagrams in Figs. 16 and 17 , where they are also put in a broader context by comparison with Hawailan lava. From the alkali-silica diagram (Fig. 16) it is seen that all lavas of Grande Comore fall on the alkalio side of the dividing line between Hawalion tholeiltic and alkalic basalts. The Kartala lavas fall in the fleld of Hawalian alkali olivine basalts, and the La Grille lavas show affinities with the Hawailan "nephelinic series" (cf. Macdonald, 1968a). 
Fig. 14 .

Variation diagrams for major elements in the Kartala lavas.

Light solid lines are olivine-augite tie-lines. Heavy dashed lines are "control lines" from average olivine/augite phenocryst ratio in cumulus-enrlohed lavas.

Oxides in weight percent. $\mathrm{F} \oplus \mathrm{O}=$ total iron as ferrous iron.

$0=$ Kartala lavas

V = augite (No. 21, Table 6).

$\nabla=$ ollvine (No. 2l, Table 4). 

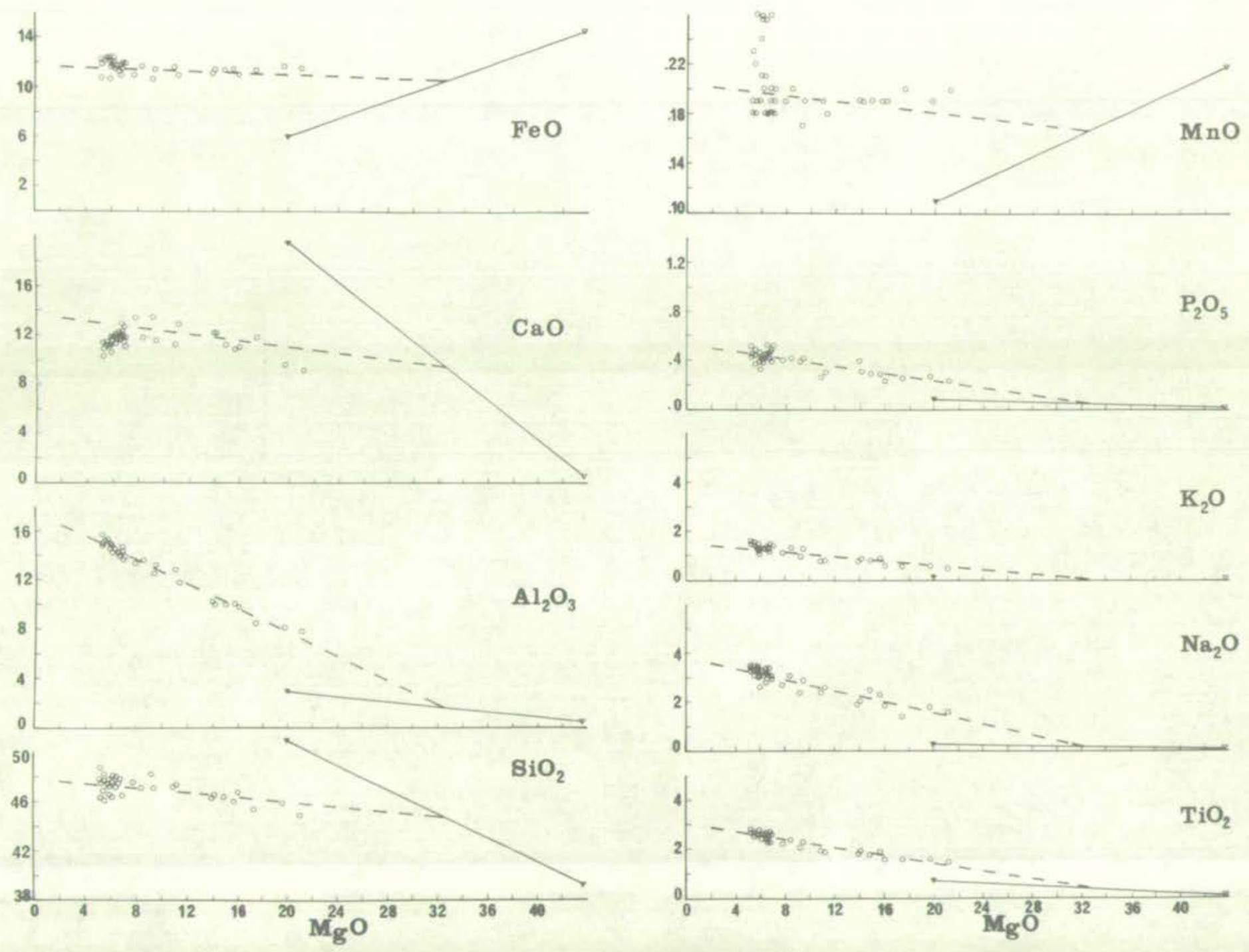
F1g. 15.

Varlation diagrams for major elements in

La Grille lavas.

Oxides in weight percent.

Feo $=$ total 1ron as ferrous 1ron.

Areas Inside dashed line are fields of Kartala lavas.

Solld lines are olivine "control lines".

- $=$ La Grille lavas

$\nabla=$ ollvine (No. 2l, Table 4 ). 

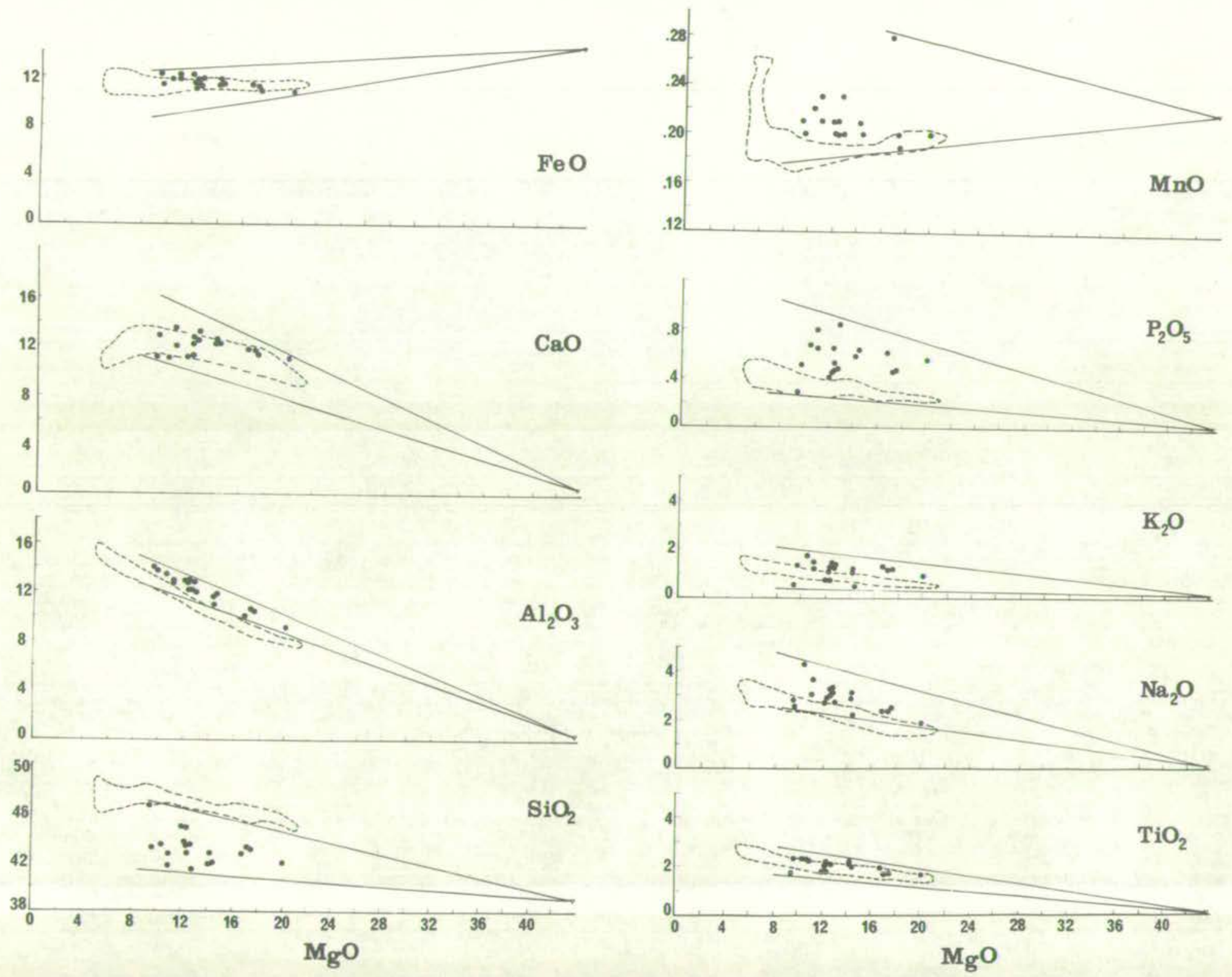
F1g. 17 is an "F.M.A." diagram, on which is plotted the alkall basalt variation trend of Hawalian basalts (Macdonald and Katsura, 1964). This diagram shows that Kartala lavas fall on the trend of Hawailan alkali basalts, while the La Grille lavas are generally less iron-enriched. The Kartala lavas show a trend away from the olivine and augite phenoorysts which they contain, while the La Grille lavas are more scattered.

5.3. C.I.P.W. NORMS OF LAVAS

The effects of oxidation on the norm of four Kartala lavas and two Badjini lavas (Tables $\mathrm{C}-1$ and $\mathrm{C}-3$ ) were eliminated by recalculating the fron to 2.00 wt $\% \mathrm{Fe}_{2} \mathrm{O}_{3}$. The value of $2.00 \% \mathrm{Fe}_{2} \mathrm{O}_{3}$ was used instead of the $1.5 \%$ recommended by Coombs (1963) because even the very fresh historic lavas of Grande Comore generally contain more than $2 \cdot 00 \% \mathrm{Fe}_{2} \mathrm{O}_{3}$, indicating that at least this much is possible as a primary feature of the magmas.

The following aspects of the nomns should be noted:

1. All analysed lava flows from Grande Comore contain nomative nepheline, and those of La Grille more than three times as much as those from Kartala (Table 13). This was summarized in Fig. 8 (Section 3.2.1.), and the separate positions of Kartale and La Grille lavas in this diagram form the basis for calling them alkali basalt and basanite groups respectively (after Coombs, 1963).

2. Normative leucite replaces normative albite in seven (37\%) of the La Grille lavas (the nepheline basalts), but never in the Kartala lavas (see Table 13). The normative feldspars 
Fig. 16.

$\mathrm{Na}_{2} \mathrm{O}+\mathrm{K}_{2} \mathrm{O}$ vs. $\mathrm{SiO}_{2}$ in Kartala and La Grille lavas.

The line separates Hawailan tholeiltic from alkali basalts (after Macdonald and Katsura, 1964).
$0=$ Kartala
- $\quad$ La Grille 


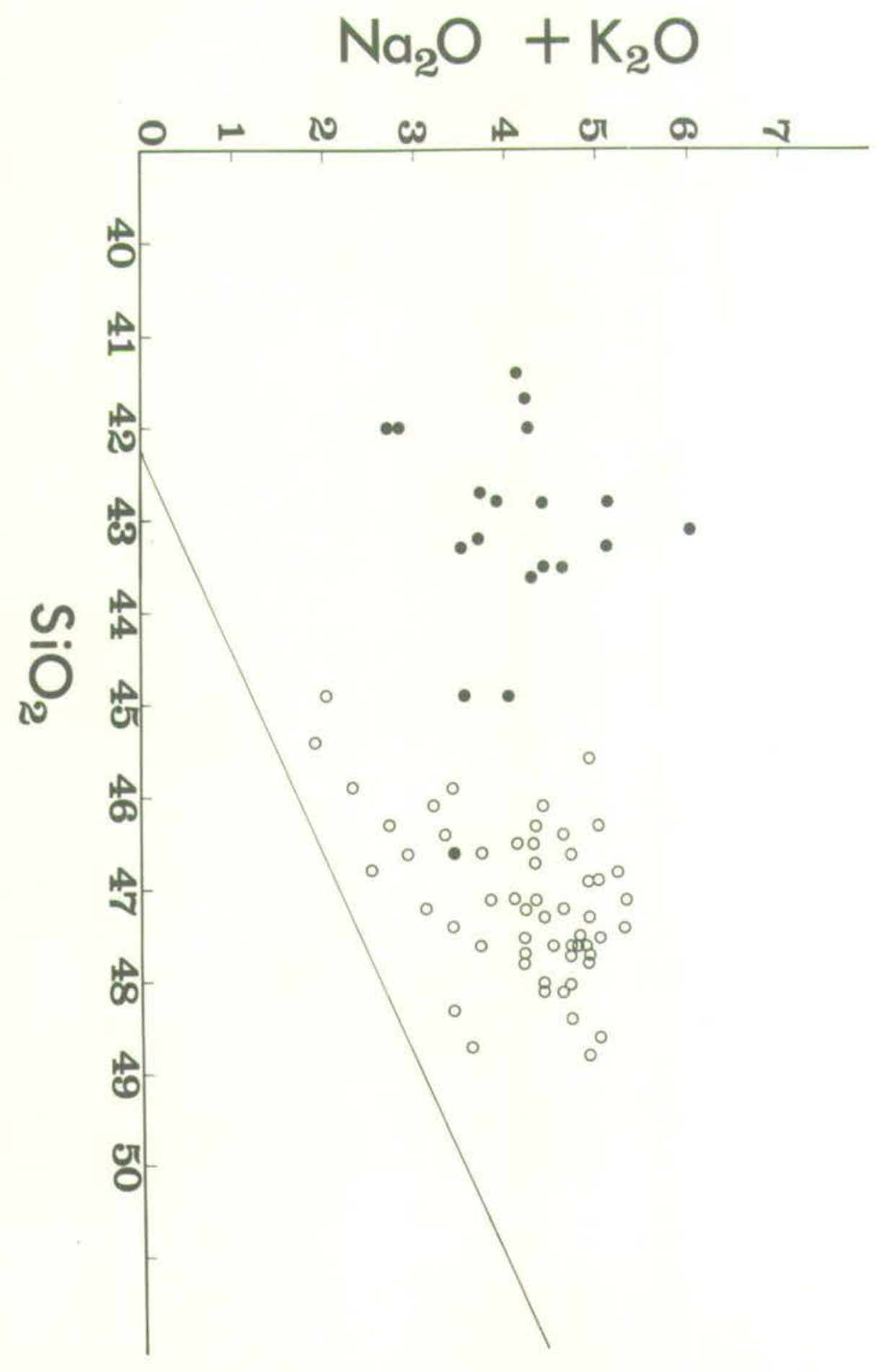


Fig. 17.

"F.M.A." diagram for Kartala and La Grille lavas (wt.\%)

F. = total fron as $\mathrm{FeO}$

M. $=\mathrm{MgO}$

A. $=\mathrm{Na}_{2} \mathrm{O}+\mathrm{K}_{2} \mathrm{O}$

Insert shows area (stippled) of the main diagram.

Dashed line shows the Hawailan alkalic trend (after

Macdonald and Katsura, 1964).

O $\quad=\operatorname{Kartala}$

- $\quad$ La Grille

$\nabla \quad=$ Kartala olivines (Table 4)

v = Kartala augites (Table 6). 


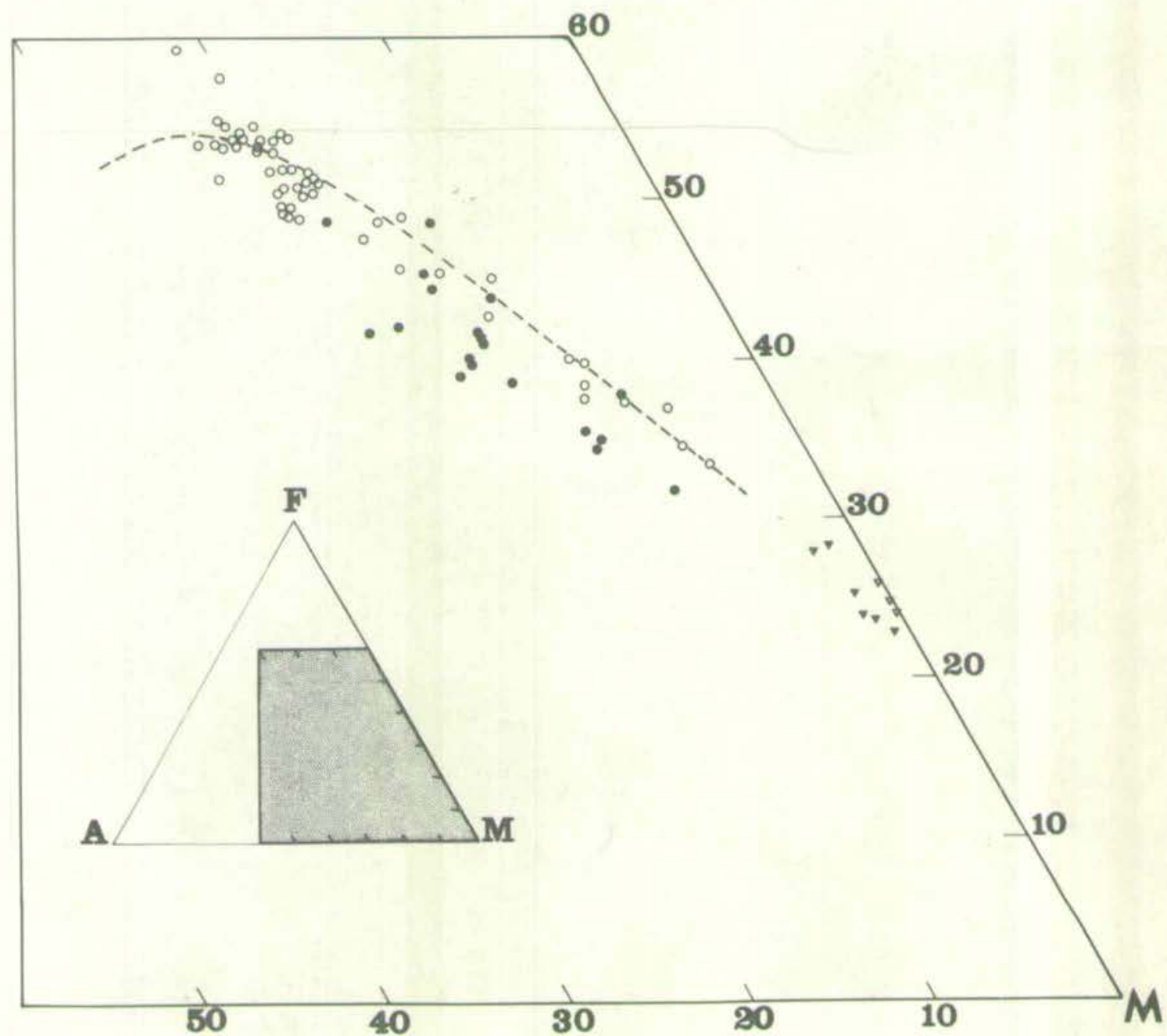


of La Grille basanites are consistently richer in An than those of the Kartala alkall basalts, with much variation in $\mathrm{Ab} / \mathrm{Or}$ ratios, as shown in Fig. 18. The Kartala normative feldspars vary only slightly between An- 40 to 50 and $0 \mathrm{r}-10$ to 20 (Fig. 18), which may be taken as a reflection of the homogeneity of the groundmass of these rocks, since the phenoorysts contribute relatively little to normative feldspar compositions (of. Table 6).

\section{Table 13.}

Relative silica-undersaturation in the lavas of Grande Comore, as indicated by normative mineralogy.

\begin{tabular}{llcc}
\hline & & nepheline & leucite \\
\hline & average & 3.72 & - \\
Kartala & low & 0.31 & - \\
& hlgh & 6.85 & - \\
& number of rocks & 46 & 3.21 \\
& average & 11.50 & 0.10 \\
\multirow{2}{*}{ La Grille } & low & 2.26 & 6.12 \\
& high & 18.74 & 7 \\
& number of rocks & 19 & \\
\hline
\end{tabular}

The variation of normative components in the "simple basalt tetrahedron" (Yoder and Tilley, 1962) is shown in Fig. 19, in which projections are made onto each face of the normative tetrahedron 
F1g. 18 .

Nomative feldspar compositions in the system albite-anorthite-orthoclase.

0 = Kartala

- = La Grille 


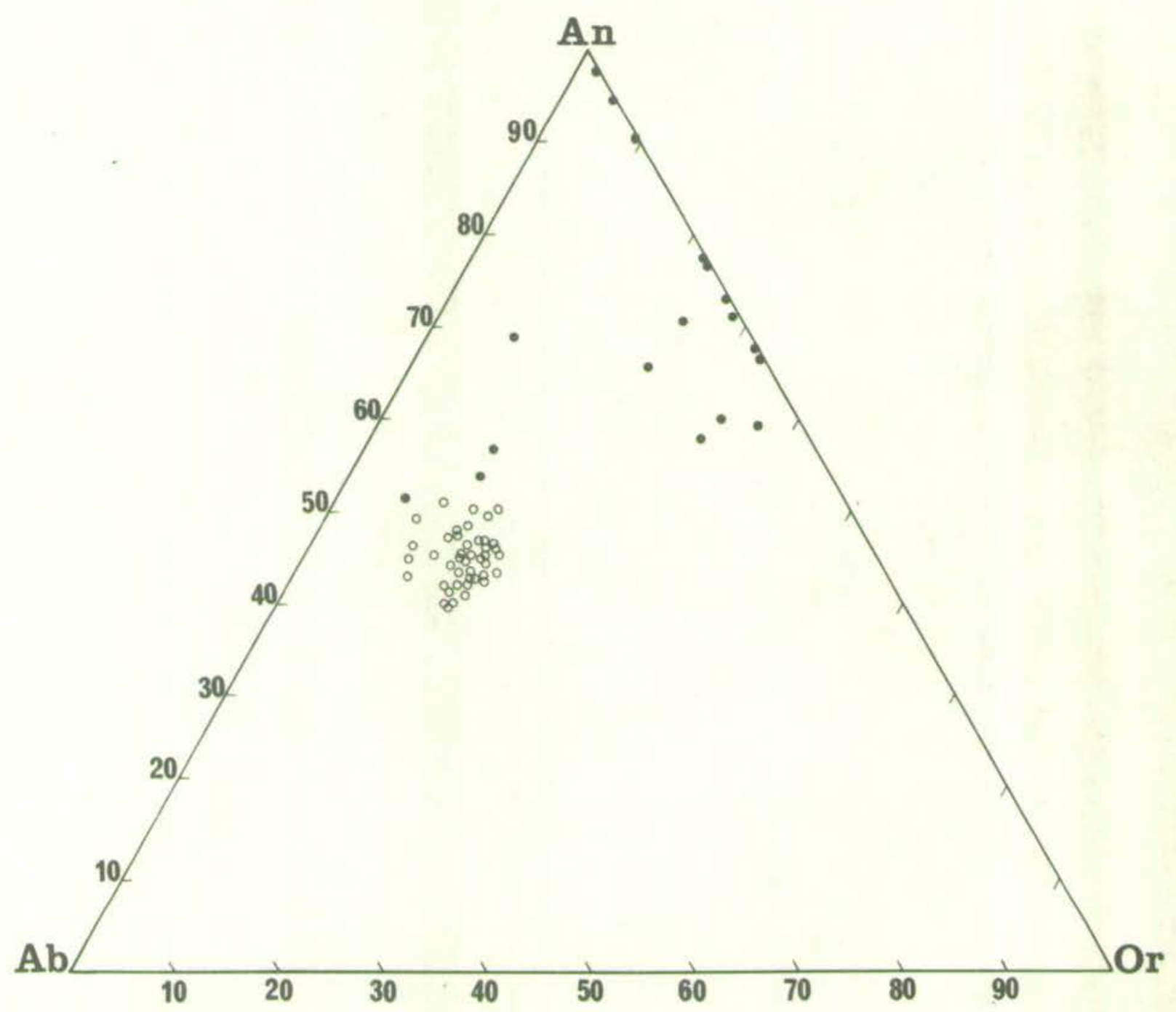


nepheline-olivine-plagioclese-diopside. Also plotted are tielines between olivine and augite, showing that, as in the simpler variation diagrams (FIg. 14), the normative trend falls on control lines from the average ratio of olivine to augite phenocrysts on this tie-ine.

A similar projection of the La Grille lavas (Fig. 20) shows no clearly defined or consistent trends. In the nepheline and plagioclase projections there is some suggestion of a trend away from the olivine-diopside foin, but in the other two projections it is not away from either of these components. This means that the La Grille trends are ontrolled by nelther olivine nor olinopyroxene. Neither the elbow-shaped cloud in the diopside projection nor any of the pattems in other projections are simply explicable as resulting from fractionation of the phases common in basaltic magmas.

\subsection{TRACE ELEMENT CHEMISTRY OF THE LAVAS}

5.4.1. Introduct1on

In terms of basalt petrogenesis, an importint crystal-chemical control of trace element behaviour is that of excluding particular elements from stable crystal lattices, thus restricting them to a purely passive role of dilution or concentration in the liquid, as governed by an increase or decrease in liquid volume. Blements which behave in this way are termed "incompatible elements" in this study (after Green and Ringwood, 1967). The inoompatibility or otherwise of a particular element is only dependent upon the particular phases stable. For example, Sr can be thought of as incompatible under upper mantle conditions but as compatible under 
Fig. 19.

Projections of norms of Kartala lavas in the silicaundersaturated part of the "simple basalt tetrahedron" nepheline-olivine-plagloclase-diopside. Insert shows planes of projection. Scele, in weight percent, is shown on the nepheline-diopside join. Dashed line is the "control line" from a point on the olivine-augite tie-1ine representing the average ratio of olivine to augite phenocrysts in the lavas.

$0 \quad=$ lavas

$\nabla \quad=$ olivine (No. 21, Table 4 ).

V = augite (No. 21, Table 6). 


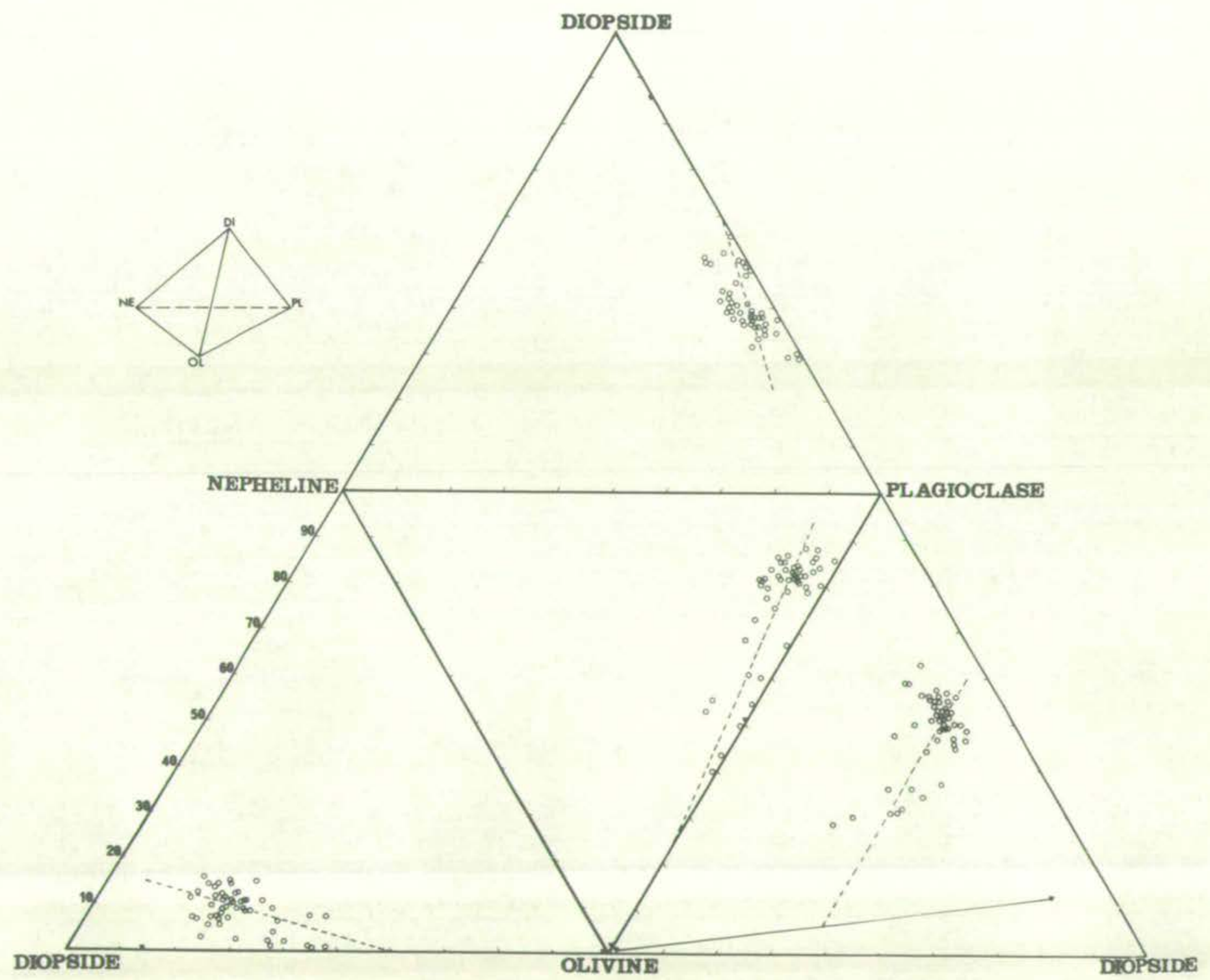


Fig. 20 .

Projections of norms of La Grille lavas, as for Fig. 19,

Areas Inside dashed line represent Kartala lavas. solld lines are olivine "control lines". 


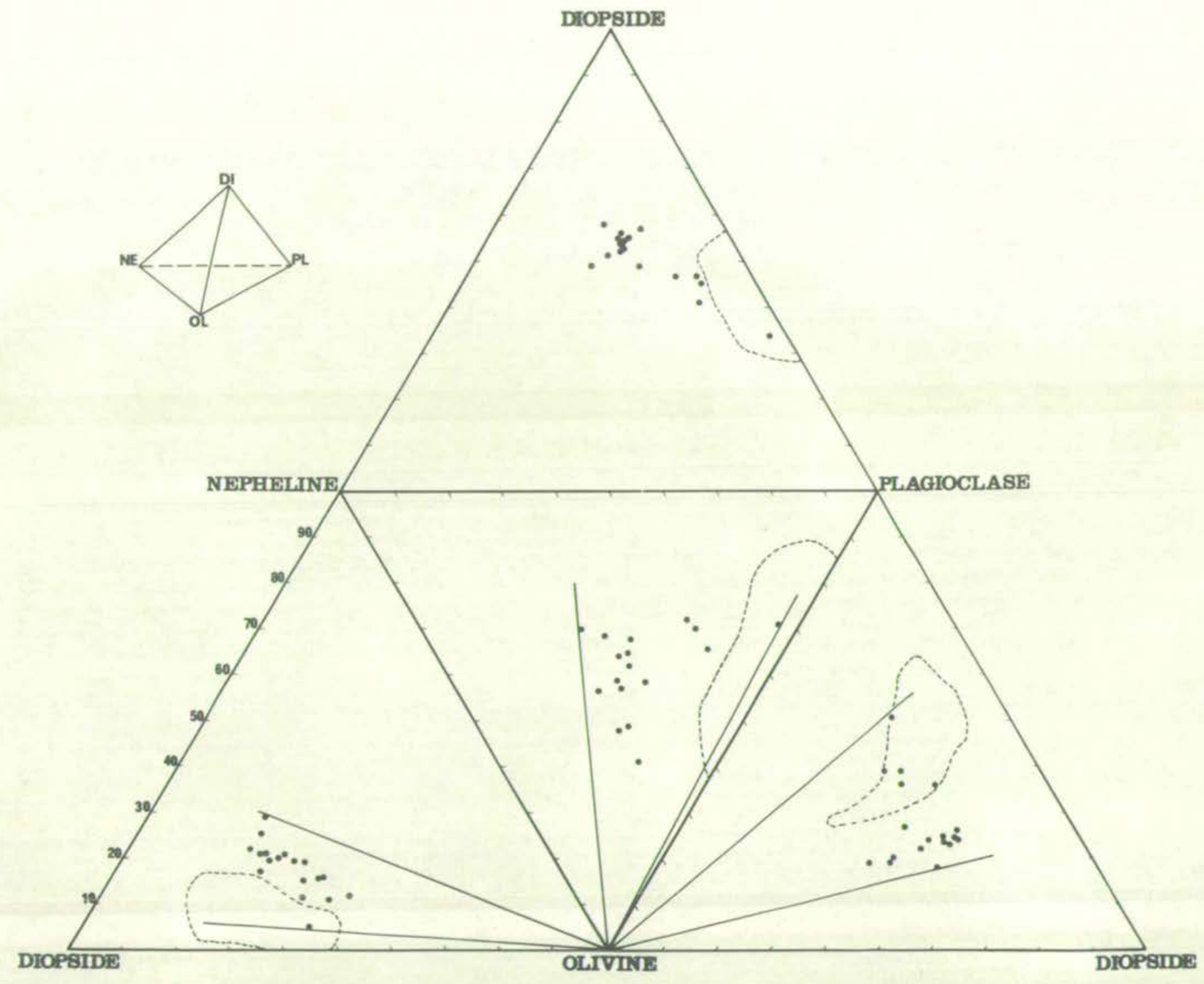


crustal conditions where plagioclase is stable (Green and Ringwood, 1967). This concept of "residual" or "incompatible" elements has been orucial to the hypotheses of basalt petrogenesis expounded by Harris (1957, 1967) and Green and Ringwood (1967).

Because of the passive behavior of incompatible elements, the concentrations of all such elements in the liquid phase will maintain linear relations to one another during processes such as partial melting and fractional crystallization. Those which deviate from linearity are not truly incompatible, and thus give important clues as to which phases may have been stable during the development of the 11quids. The relative and absolute concentrations of a variety of trace elements in basaltic liquids are thus sensitive and easily Interpreted indications of the petrogenetic history of these liquids.

The trace elements determined in the present study were chosen to represent a range of both compatible and incompatible elements common in hasaltic magmas.

5.4.2. His togreams

The distributions of trace elements in the lavas of Grande Comore are show as histograms in Fig. 21, along with those for "nepheline-nomative alkali basalts" complled by Prinz (1967, p. 281, Fig. 1). The following general features are noteworthy.

1. As noted for major elements, the La Grille trace element distribution patterns are oloser to normal than those of Kartala.

2. The range of concentration is greater in La Grille than in Kartala lavas for all elements except Cu, which has a strikingly narrow range. 
Fig. 21.

H1stograms of trace element distributions in

(a) La Grille and (b) Kartala levas.

St1ppled areas represent data complled by

Prinz (1967, Fig. 1), scaled down to

one tenth. 

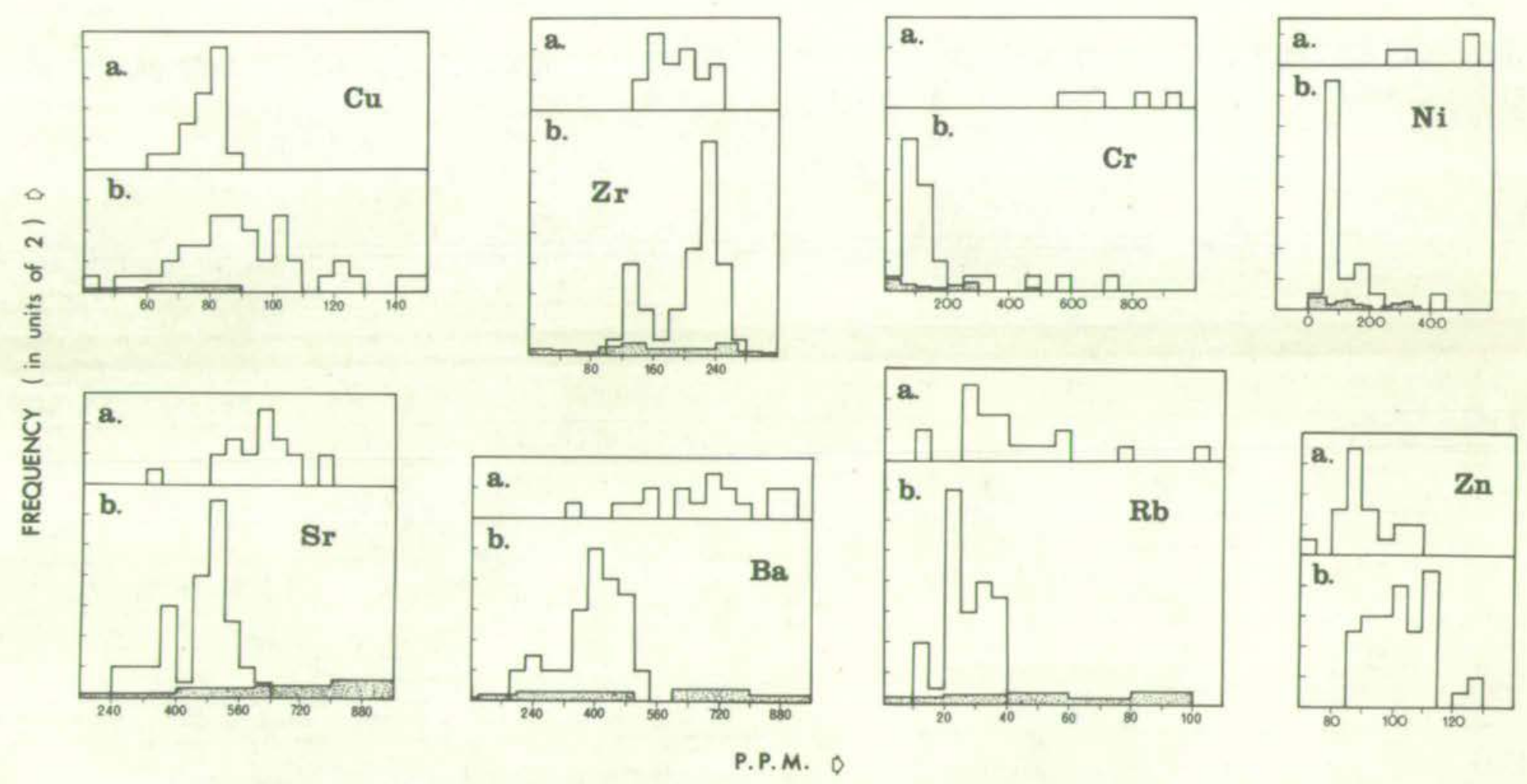
3. Relative to Kartala, the La Grille lavas are enriched in all elements except $\mathrm{Cu}$ and $\mathrm{Zn}$, the concentrations of which are lower.

5.4.3. Variation diagrams

The variation of trace elements with respect to MgO is shown for Kartala and La Grille lavas in Figs. 22 and 23, respectively. As was done for the major element variation diagrams (Fig. 14), the ollvine-augite control lines are drawn for Kartala lavas, and it is clear that, except for $\mathrm{Cu}$ and $\mathrm{Zn}$, the trace element concentrations are likewise controlled by these phases.

The variation of trace elements in La Grille lavas (Fig. 23) is much more haphazard than in those of Kartala. For example, Rb can be seen to vary by as much as $100 \%$ at constant MgO content.

The $\mathrm{K} / \mathrm{Rb}$ ratios of 1gnoous rooks, regarded by meny workers as sensitive indieators of their "primitiveness" or degree of differentiation from the mantle (e.g. Shaw, 1968; Gast, 1965, 1968), are shown in Fig. 24. It can be seen from Fig. 24 that the Kartala lavas have $\mathrm{K} / \mathrm{Rb}$ ratios between 300 and 600 , similar to alkali basalts in general (Gast, 1968). The La Grille $\mathrm{K} / \mathrm{Rb}$ ratios are mostly between 150 and 350 , but reach as low as 35 (No. 165, Table C-2).

\subsection{RARE-EARTH ELEMEANTS}

Rare-earth elements have been determined for one rock each from Kartala and La Grille (Table 14). The La Grille rare-earth concentrations are consistently higher then those of Kartala, by an average factor of 1.7 . This factor is higher than that for other incompatible elements (of. Table 16), but it is probable that 
F1g. 22.

Variation of trace elements with MgO In Kartala lavas.

MgO in welght peroent, trace elements in ppm.

Symbols and Iines as for Pig. 14 . 

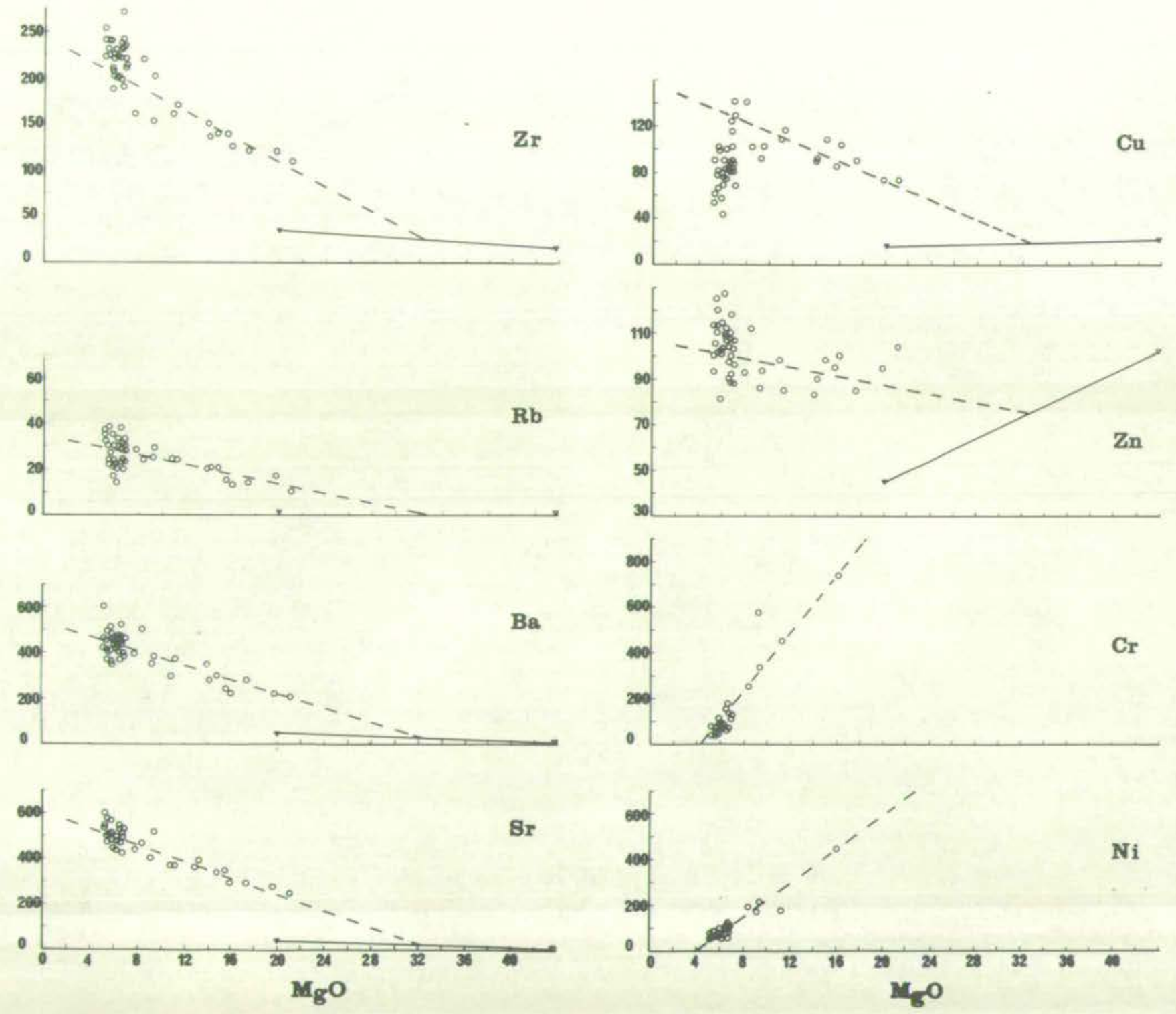
Fig. 23.

Variation of trace elements with Mgo in

La Grille lavas.

$\mathrm{MgO}$ in weight percent, trace elements in ppm.

Symbols and lines as for Fig. 15. 


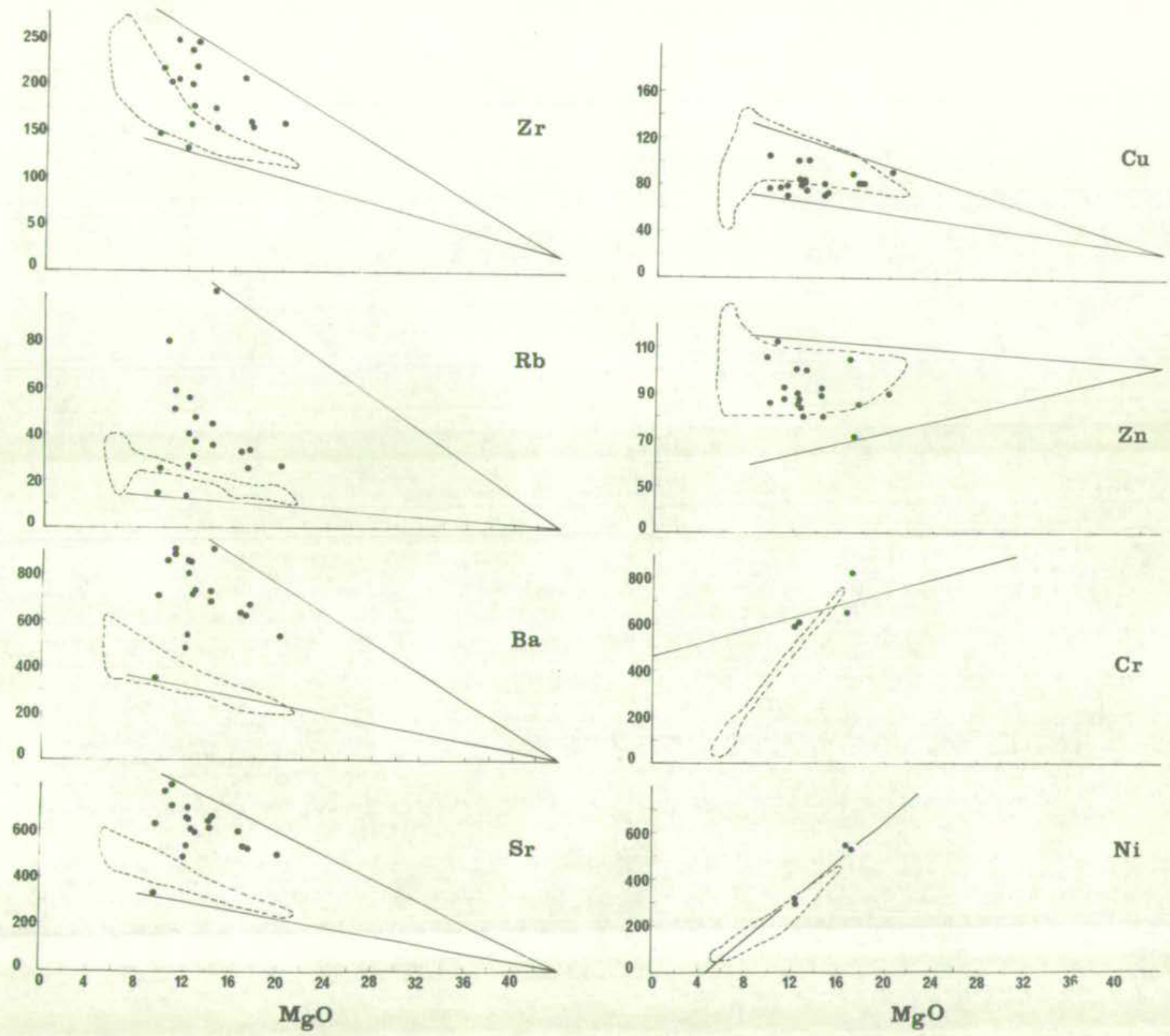


these two rocks are not quantitatively representative of the volcanoes as a wole. The patterns of distribution of the rareearth elements (F1g. 25) are comparable to those for similar rooks elsewhere (of. Sohtlling and Winchester, 1967, 1969).

5.6. OHEMISTRY OF OTHER ANALYSED ROCKS

5.6.1. Badjini lavas

The Badjini lavas (Table c-3) are ohemically similar to those of Kartala, except for Nos. 156 and 158. The higher MgO and Ba contents of these two lavas suggest an affinity with those of La Grille, as was indicated by petrographic features. 5.6.2. Intrusive rocks

The three basaltic dykes from the Kartala caldera (Nos. 105, 107, and 110, Table $\mathrm{C}-4$ ) have higher $\mathrm{Al}_{2} \mathrm{O}_{3}$ and $\mathrm{K}_{2} \mathrm{O}$ than most other Kartala rocks, and are also more differentiated, with differentiation Indices from $32 \cdot 7$ to $37 \cdot 5$. The two coarse-gralned blocks from the caldera floor (Nos. 42 and 44, Table $\mathrm{C}-4$ ) have higher total iron, $\mathrm{TIO}_{2}$, and $\mathrm{K}_{2} \mathrm{O}$, and lower $\mathrm{MgO}$, and are also more differentiated than most of the Kartala lavas.

\subsubsection{Pyroclastic rocks}

The vitric crystal-tuff (No. 16, Table c-5) is rich in water $(5 \cdot 93 \%)$ and ferric iron $(5 \cdot 32 \%)$. Because all water must be contained in the glass, which makes up only $73 \%$ of the rock (Table B-5), the water content of the glass must be around $8 \cdot 1 \%$. This roak might therefore be described as palagonitic.

The basanitio block No. $38 \mathrm{~A}$ (Tables B-5 and C-5) shows petrographic indications of weathering which is chiefly reflected in the 


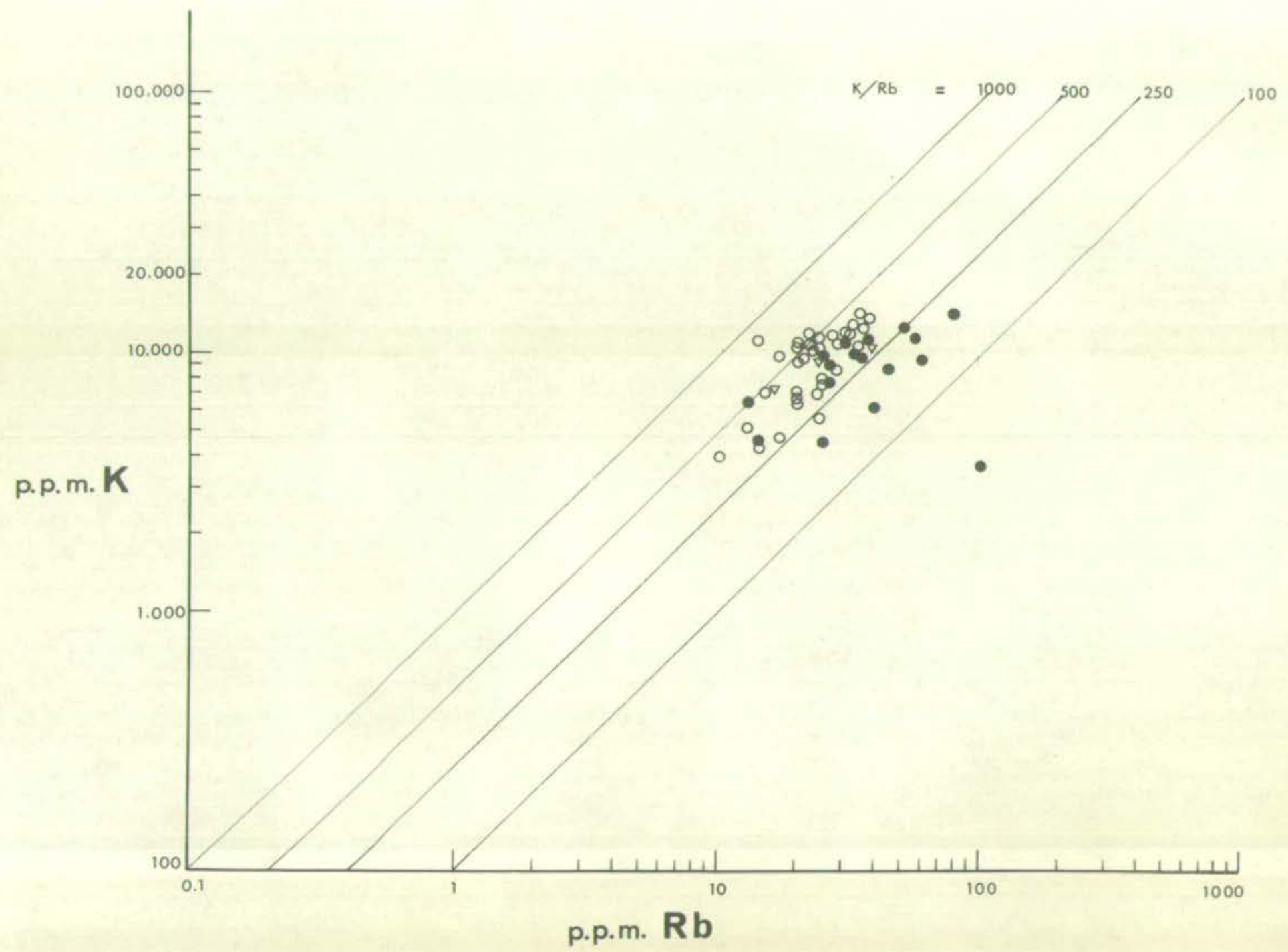


F1g. 25 .

Rare-earth elements in samples No. 1 (Kartala)

and 9 (La Grille), normalized to chondritic values given by schmitt, et al. (1964).

$0 \quad=$ Kartala

- $=$ La Grille 


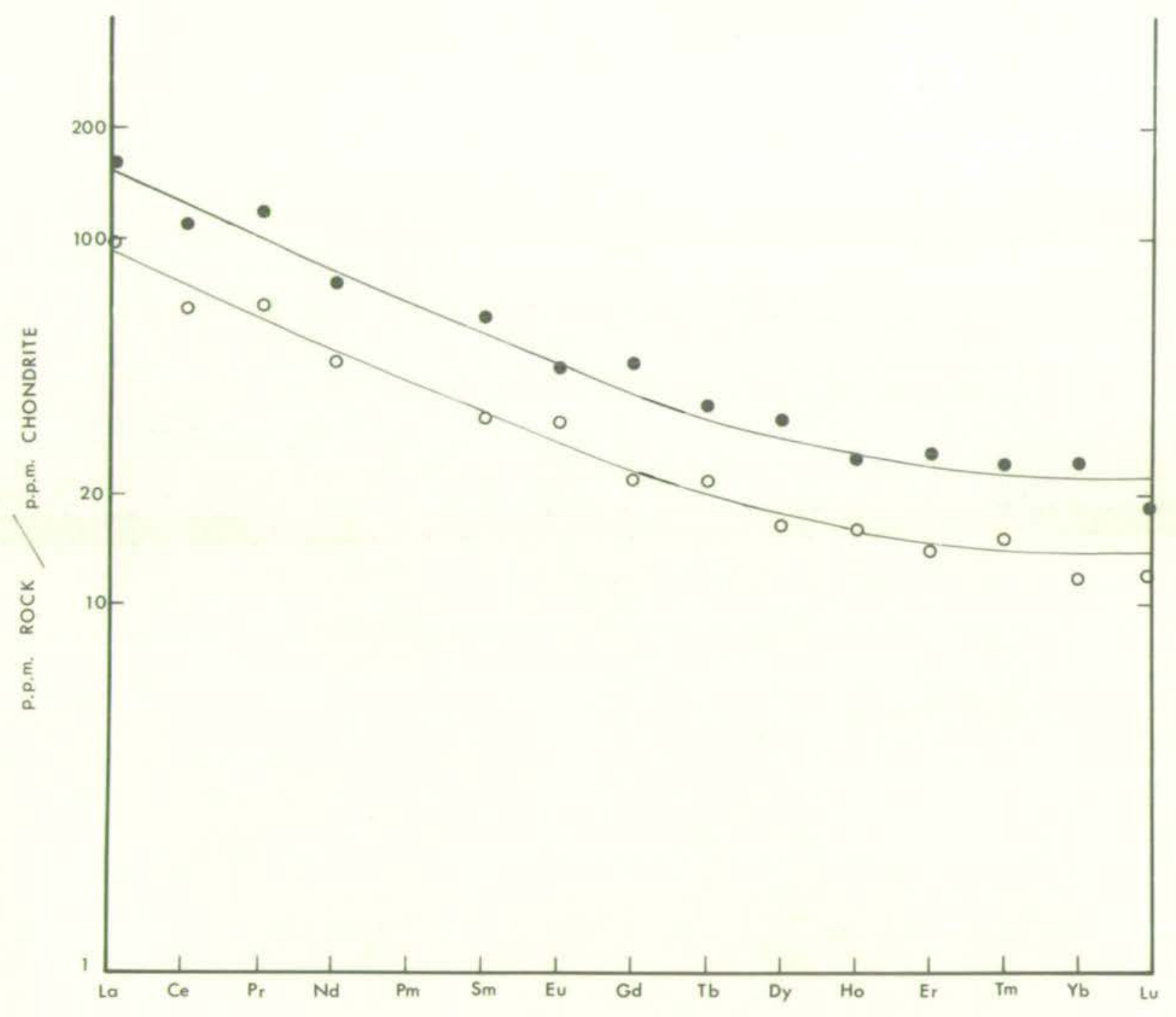


Table 14.

Rare-earth elements

\begin{tabular}{lcrc}
\hline ppm & Kartala (No.1) & La Grille (No.9) & La Grillo/Kartala \\
\hline La & 29.44 & 48.01 & 1.63 \\
Ce & 54.01 & 90.72 & 1.68 \\
Pr & 7.91 & 14.17 & 1.79 \\
Na & 26.67 & 43.86 & 1.64 \\
Sm & 7.14 & 12.80 & 1.80 \\
Eu & 2.44 & 3.31 & 1.36 \\
Gd & 7.03 & 14.77 & 2.10 \\
Tb & 1.28 & 2.02 & 1.97 \\
Dy & 5.12 & 10.03 & 1.95 \\
Ho & 1.17 & 1.82 & 1.56 \\
Er & 2.95 & 5.55 & 1.88 \\
Pm & 0.50 & 0.80 & 1.60 \\
To & 2.01 & 4.13 & 2.05 \\
Lu & 0.35 & 0.55 & 1.57 \\
\hline TOTAL & 148.02 & 252.54 & 1.71 \\
\hline
\end{tabular}

high water content $(2 \cdot 44 \%)$. The high Sr concentration is almost certainly due to the abundant calcareous vesicle fillings.

5.6.4. Feldspar-phyric rocks

The feldspar-phyric basalt boulder No. 30 (Tables B-5 and C-5)

Is similar in most chemical aspects to the other Kartala lavas, except that its high modal feldspar is reflected in high concentrations of $\mathrm{Na}_{2} \mathrm{O}, \mathrm{K}_{2} \mathrm{O}, \mathrm{Ba}$, and $\mathrm{Sr}$.

The feldspar-phyrio basalt found as beach cobbles (No. 130, Tables $B-5$ and $(-5)$ is the only unoxidized basalt with normative hypersthene found on Grande Comore. As such, it is the only 
Indication that tholelitic rocks (using the derinfition of Yoder and rilley, 1962) may occur there.

5.7. STATISTICAL ANALYSIS OF LAVA CHEMISTRY

5.7.1. Introduction

It is clear that there are obvious chemical differences between Kartala and La Grille lavas, and that almost any element determined In this study can be used to distinguish between these two groups of lavas. The overlap in distribution of most elements, however, makes it difficult to assign some samples to one group or another. This might be better accomplished by some combination of the elements instead of any one alone.

The C.I.P.W. nom is a conventional method of expressing a combination of the major elements, and it has been shown in Fig. 8 that these are largely successful in separating the lavas of each volcano. However, this method of discrimination still results in some overlap between the two groups, so that problems may st111 arise in classifyling some specimens.

In an attempt to refine the classification of samples on the basis of bulk chemistry, the statistical method of discriminant function analysis has been employed. This method is described in standard statistical textbooks (e.g. see Goulden, 1952; Hope, 1968), and some of its geological applications are discussed by Krumbein and Graybill (1965). It has been summarized in Appendix D. 5.7.2. Disoriminant function analysis

To oaloulate the discriminant functions (see Appendix D), samples were carefully selected on geographic and geomorphologlcal 
grounds as definitely belonging to one or the other volcano. 38 analyses were from Kartala and 14 from La Grillo, and those collected in zones of uncertain derivation, between the volcanic centres, were treated as unknowns. The characteristic numbers and deciding disoriminant functions so calculated are given in Table D-1 so that any future analyses of lavas from Grande Comore may be objectively compared to those from each volcano, and assigned to one or the other if its origin is unknown.

Results of the disoriminant function analysis are shown diagrammatically in Figs. 26 and 27. On the basis of trace element ooncentrations alone, (Fig. 26), the Kartala and La Grille lavas can be separated at a significance level of $0.1 \%$; $1 . \theta$. there is a $0.1 \%$ chance of error in assuming that they are different. Using trace elements only (Pig. 26), the Badjini lavas 156 and 158 appear to be more closely related to the La Grille lavas than those of Kartala, as predicted on petrographic grounds. One sample from La Grille, No. 57, was incorrectly assigned to the Kartala group; this sample plots in the field of Kartala lavas in all diagrams used in this study.

Although the statistical significance of the major element discrimination could not be estimated due to their non-normal distribution (see Appendix D), it can be seen from F1g. 27 that the separation of the two groups of lavas using major elements is just as distinct as that obtained using trace elements. However, the Badjini lavas 156 and 158 are now assigned to the Kartala group and 147 to the La Grille group, contrary to that expected on petrographio grounds. 
Fig. 26.

Disoriminant funotions calculated from trace element ooncentrations.

Vertical scale gives value of discriminant function.

Significance of discrimination $=0.1 \%$. 


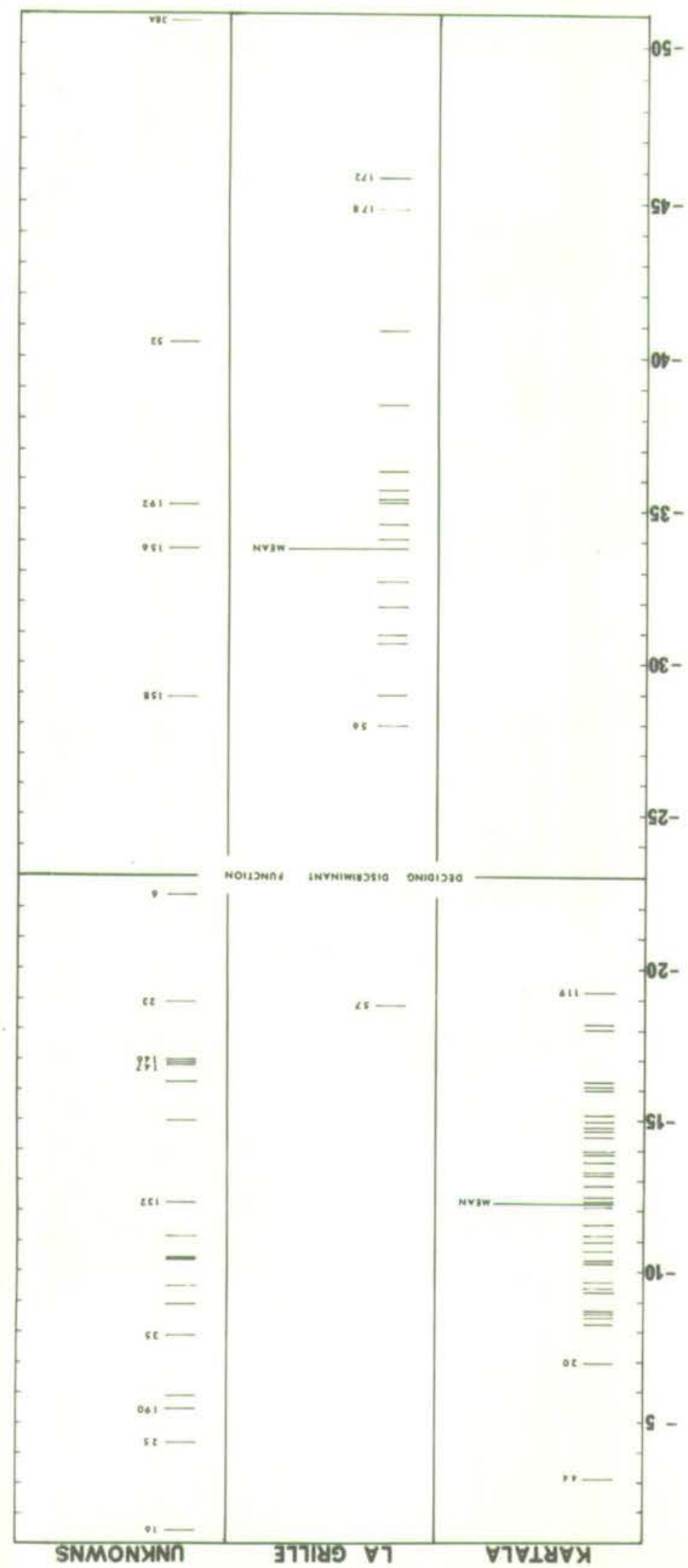


Fig. 27.

Disorfminant functions calculated from mejor element concentrations.

Vertioal scale gives value of discriminant function, Signiflcance of discrimination not calculated (see text). 


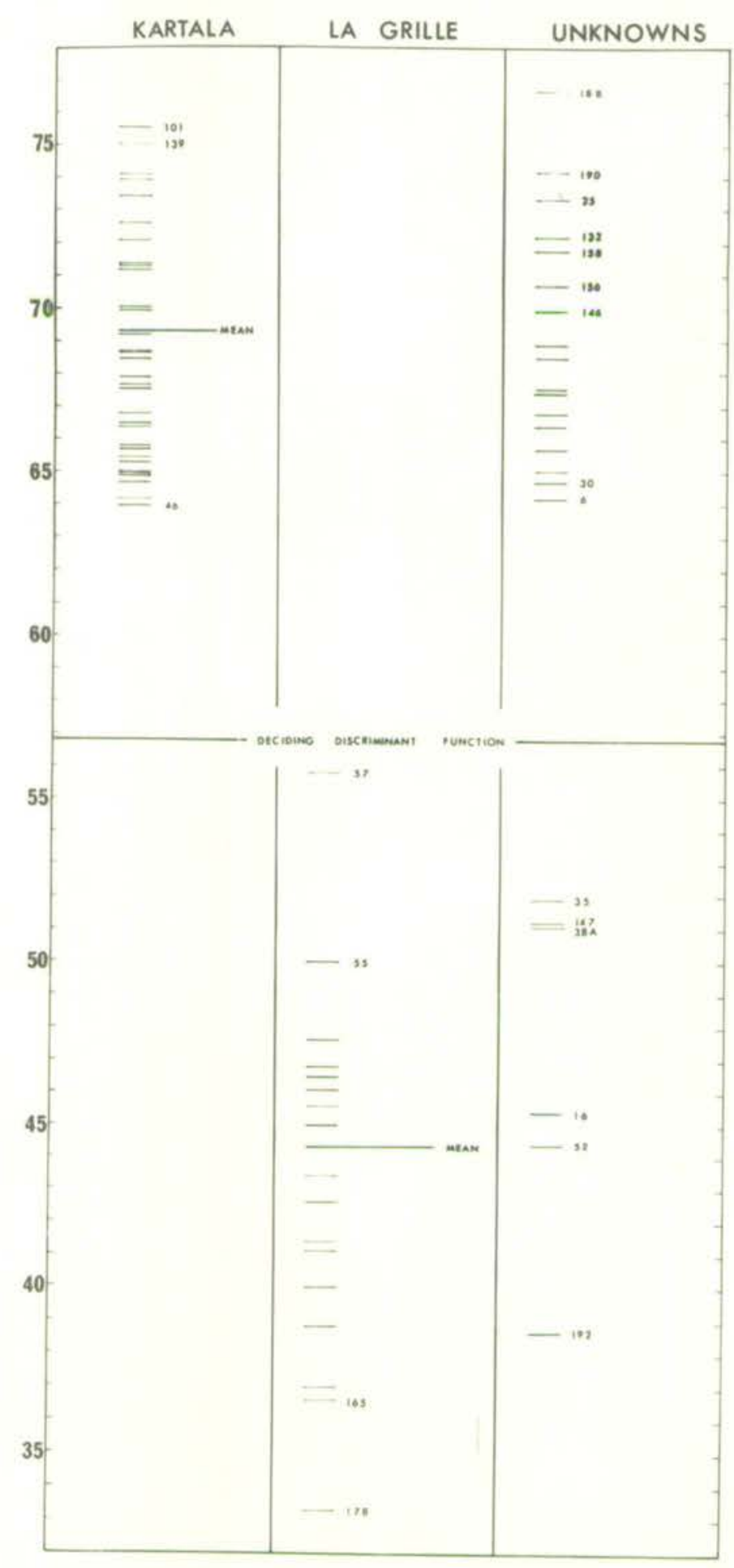


In surmary, the discriminant function analys is has shown that a) there are highly significant trace element (and possibly major element) differences between the lavas of each volcano; b) the geochemical boundaries ooinclde with the geographic and geomorphological boundaries (of. Figs. 3 and 5); and o) the petrographic classification of Badjini lavas is supported by the trace element discriminant functions.

5.8. SUMMARY

Lavas of the two volcanoes of Grande comore form two distinct chemical groups. Geochemical boundaries can be drawn on a locality map of analysed specimens, and these boundarles coinclde with the geomorphological boundaries between each volcano as proposed in Chapter 2.

The lavas of La Grille are more silica-undersaturated than those of Kartala, with an average of three times as much norrative nepheline; and they commonly contain normative leucite, which is absent from the Kartala lavas.

The patterns of distribution of both major and trace elements are more normal for the La Grille lavas than for those of Kartala. The Kartala variation trends, in both MgO variation diagrams and normative projections, fall on control lines to olivine and augite in the average proportions in which they are present as phenocrysts. The La Grille lavas do not have clearly defined variation trends, and do not fall on control lines to any common basaltic crystalline phase or combination of pheses. 


\section{DIPHEREMT IATION OF THE LAVAS}

6.1. INTRODUCTION

It was shown in the preceding chapters that, although the Kartala and La Grille lavas were simultaneously active in the same geologloal setting, each has its own distinctive lava chemistry. The origin of these chemioal differences will be discussed in Chapter 7, and the purpose of the present chapter is to examine possible causes of variation within each group of lavas. Before discussing these variations speciflcally, it is convenient at this point to consider possible effects of contamination from the silicic rocks through which these lavas must have passed.

The sandstone inclusions in the lavas show petrographic indications of reaction with the lavas (Chapter 2), and this presumably has some effect on the lava chemistry. Such effects must be minor, however, since the trace element concentrations in an arkosic sandstone from Mohell $(\mathrm{Table} \mathrm{C}-5)$ do not show any consistent relation to those of either the Kartala or La Grille lavas, nor do the $\mathrm{Rb} / \mathrm{Sr}$ or $\mathrm{K} / \mathrm{Sr}$ ratios (of. Green and Ringwood, 1967, Table 21) show any indications of crustal contamination (Table 15). Furthermore, the concentrations of rare-earth elements (F1g. 25) appear to be higher in La Grille than Kartala lavas and have similar distributions in both. This is contrary to what should result from orustal contamination (cf. Haskin and Gohl, 1962). Crustal contamination is consequentiy dismissed as unimportant as a cause of the chemical variations in the lavas of Grande Comore. 
Table 15

Average $\mathrm{K} / \mathrm{Sr}$ and $\mathrm{Rb} / \mathrm{Sr}$ in Kartala and La Grille lavas

\begin{tabular}{lcc}
\hline Kartala lavas & $\frac{\mathrm{K} / \mathrm{Sr}}{21}$ & $\frac{\mathrm{Rb} / \mathrm{Sr}}{0.056}$ \\
La Grille lavas & 16 & 0.067 \\
* Crust-contaminated lavas & $31-88$ & $0.12-0.4$ \\
* Mantle-contaminated lavas & $10-22$ & $0.015-0.07$ \\
\hline
\end{tabular}

* Green and Ringwood (1967, Table 21).

6.2. DIFFEREATITATION OF THE KARTALA LAVAS

The phenocryst assemblages in the Kartala lavas (Table B-1)

are as follows:

olivine

olivine + augite

olivine + augite + plagioclase

olivine + plagioclase

augite + plagioclase

These are set in a groundmass of olivine + augite \pm plagioclase \pm glass + opaque oxides. The order of crystallization appears to have been olivine $\rightarrow$ augite $\rightarrow$ plagioclase $\rightarrow$ opaque oxides, and the ubiquitous presence of groundmass olivine shows that it is not Involved in any reaction relation - as the phenocryst assemblage augite + plagioclase might suggest. The abundance of olivine and augite phenocrysts in many of the lavas makes these phases important contributors to the overall chemical variation. 
The most basic analysed aphyric lava from Kartala is glassy spatter from the Haboho oinder cone (No. 142, Table $\mathrm{C}-1$ ), containing 7.0\% $\mathrm{MgO}$. Lavas with higher $\mathrm{MgO}$ contents show a continuous increase in ferromagnesian phenocryst content with rising $\mathrm{MgO}$. This can be seen from the histogram of phenocryst content versus $\mathrm{MgO}$ (Fig. 28b) or the plot of olivine phenocryst content against normative olivine (Fig. 29b). It has also been shown (Section 5.2.3.) that the varlation trends for all elements in these lavas fall on what are inferred to be "control lines" from points on the olivine-augite foin.

A reasonable explanation of these features is that they result from crystal-1iquid fractionation, a process well-established for at least one other volcano (Murata and Richter, 1966a, b). It is hereafter considered that those lavas more basic than No. 142 have been enriched in variable amounts of cumulus olivine and augite, and that the less basic magmas were Impoverlshed in these phases. The faintiy linear trends in these less basic lavas appear to result from augite fractionation.

In order to estimate the physical conditions under which fractional crystallization of the Kartala lavas took place, their compositions have been projected on planes within the "C.M.A.s. system" (Fig. 30), as described by O'Hara (1968) and Jamieson (1969, 1970). These diagrams have a considerable advantage over other diagrams in that most components of a rock analysis are used in the projections. Although there is a slight disadvantage that variations In ratios such as $\mathrm{FeO} / \mathrm{MgO}$ or $\mathrm{Na}_{2} \mathrm{O} / \mathrm{CaO}$ are lost, this can be remedied by contouring the diagrams with any such parameter which may be important. 
Fig. 28.

Histogram of phenocryst distribution as a function of MgO content in (a) La Grille and (b) Kartala lavas.

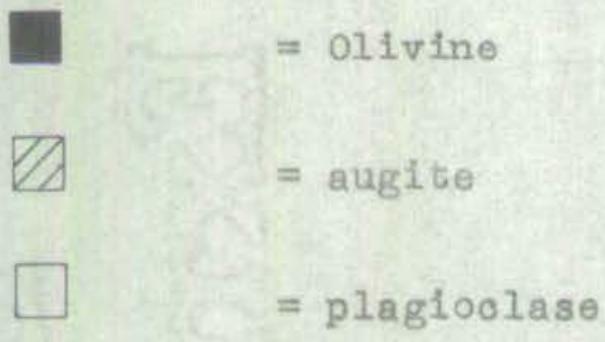




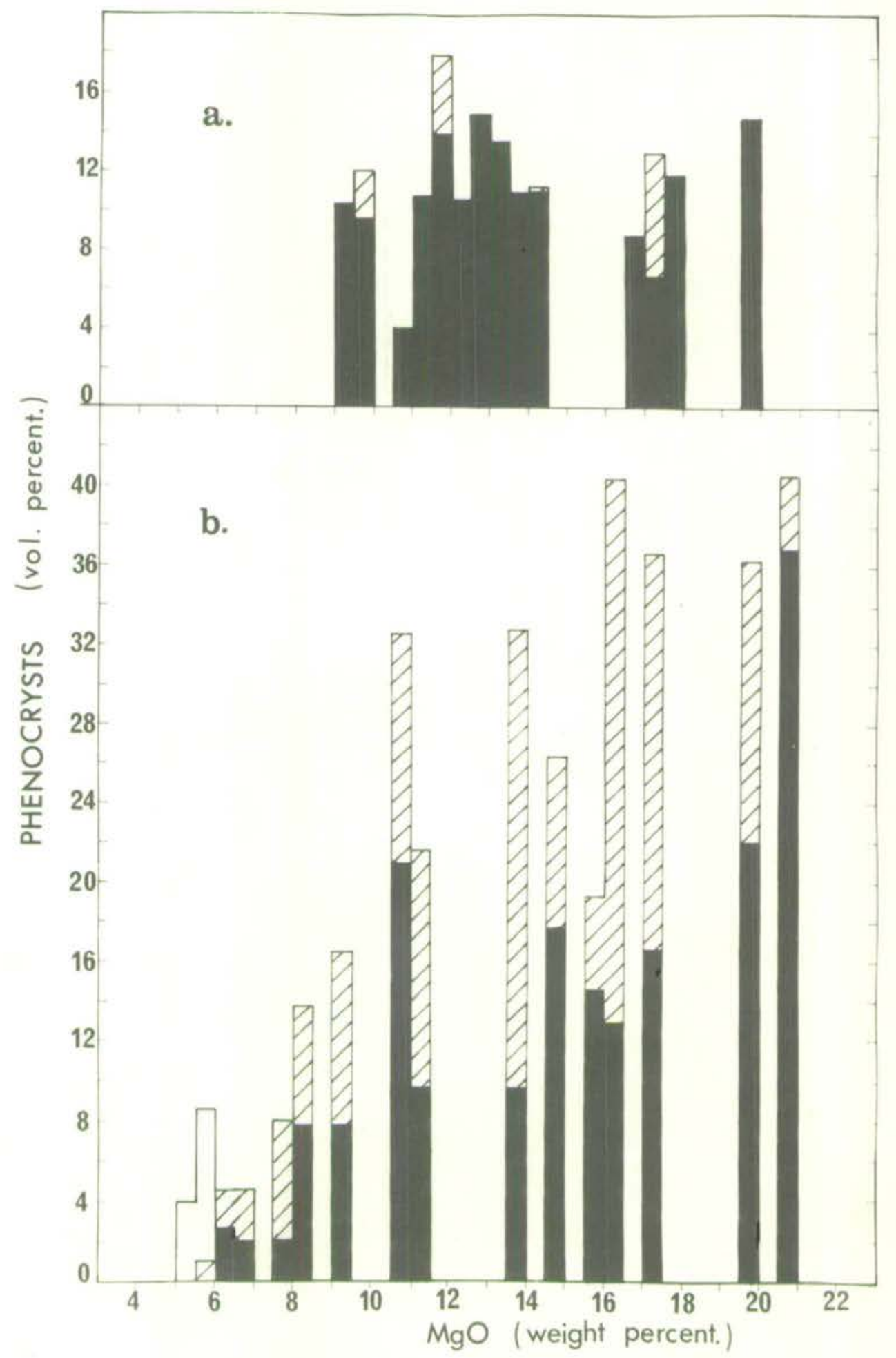




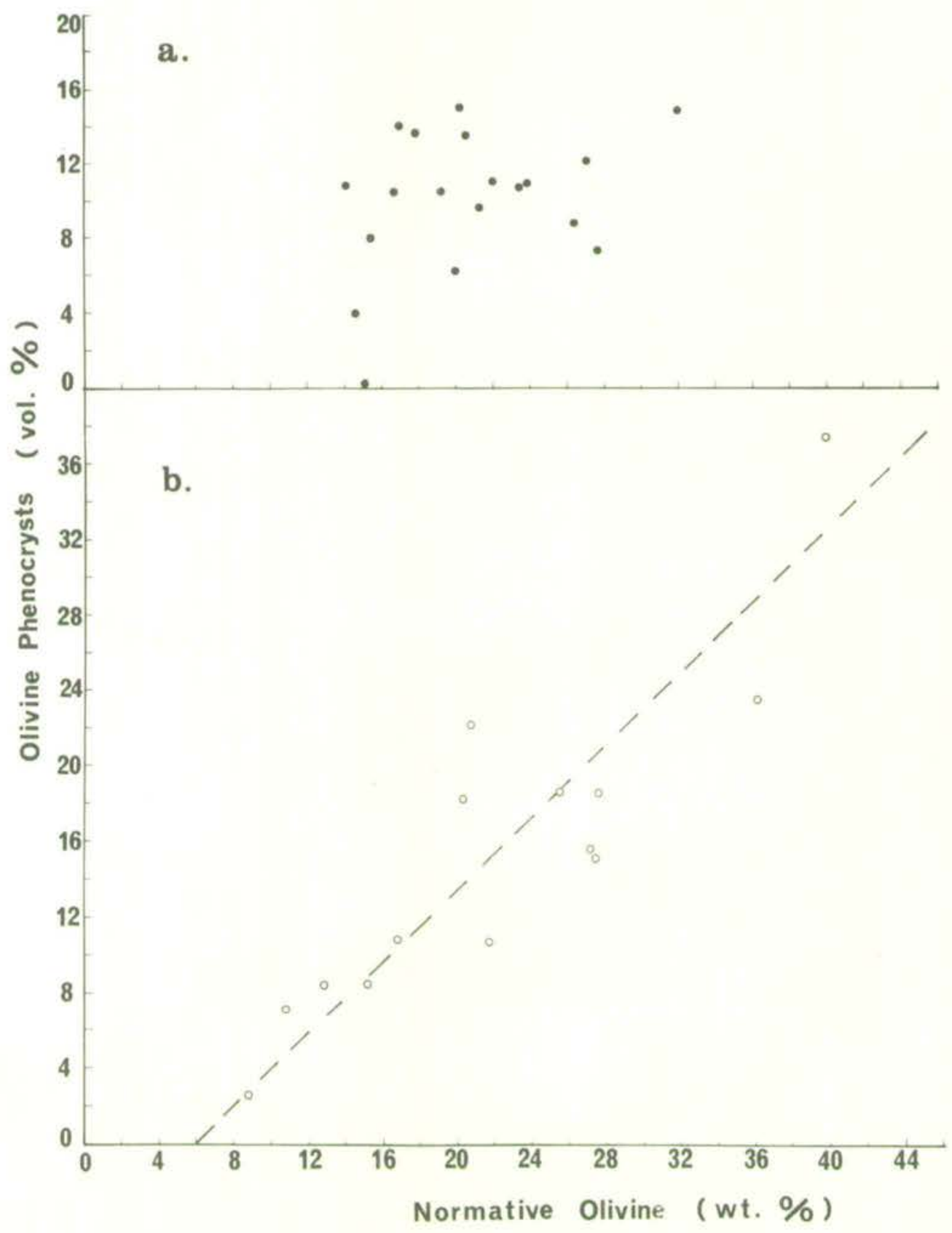


The phase boundaries shown in Fig. 30, and subsequent diagrams, were constructed by O'Hara (1968, Figs. 4 to 6) from melting exper1ments on natural and complex synthetic compositions. These phase boundaries are accepted by the present writer as essentially correct, since it seems unlikely that such consistent results could otherwise be obtained from so many independent workers (see O'Hara, 1968 , p. 85).

From the correspondence between the aphyric lava compositions and the atmospheric pressure cotectios in Fig. 30 , it is concluded that crystallization of these lavas has taken place at very shallow depths, probably less than $10 \mathrm{~km}$. This agrees with the suggestion from structural considerations (Section 2.7.2.) that the Kartala ealdera resulted from stresses applied (at the tops of magma chambers) at depths of $5 \mathrm{~km}$ or less. One might visualize the collection and crystallization of magma similar to No. 142 in a plexus of shallow magma chambers beneath Kartala, similar to the situation outlined for Kilauea by Fiske and Kinoshita (1969).

Although it is unlikely that the full range of Kartala lavas were forinec by the fractional orystallization of one unique "parent magma" (of. O'Hara, 1965), it w111 be assumed in further discussions that the range of "parent magmas" that ascended into shallow magma chambers can be adequately represented by the most basic liquid, No. 142. This assumption at least avolds the errors inherent in calculating an average, although the reader may want to refer to the average composition of Kartala lavas given in Appendix D. The composition of No. 142, recalculated water-free, is given in Table 16 . 
Fig. 30.

Projections of Kartala lava compositions in the C.M.A.S. pseudo-quaternary system (after O'Hara, 1968; Jamieson, $1968,1970)$.

$\mathrm{C}=$ (mol. prop. $\mathrm{CaO}-3 \frac{1}{3} \mathrm{P}_{2} \mathrm{O}_{5}+2 \mathrm{Na}_{2} \mathrm{O}+2 \mathrm{~K}_{2} \mathrm{O}$ ) $\times 56 \cdot 08$.

$\mathrm{M}=$ (mol. prop. $\left.\mathrm{PeO}+\mathrm{MnO}+\mathrm{NiO}+\mathrm{MgO}^{-} \mathrm{THO}_{2}\right) \times 40 \cdot 31$.

$\mathrm{A}=$ (mill. prop. $\mathrm{Al}_{2} \mathrm{O}_{3}+\mathrm{Cr}_{2} \mathrm{O}_{3}+\mathrm{Fe}_{2} \mathrm{O}_{3}+\mathrm{Na}_{2} \mathrm{O}+\mathrm{K}_{2} \mathrm{O}+\mathrm{PlO}_{2}$ ) $\times 101 \cdot 96$.

$\mathrm{S}=$ (mol. prop. $\left.\mathrm{SiO}_{2}-2 \mathrm{Na}_{2} \mathrm{O}-2 \mathrm{~K}_{2} \mathrm{O}\right) \times 60.09$.

Inserts show planes of projections.

a. Projection from diopside onto $C_{3} A-M-S$ (wt $\%$ ).

b. Projection from ollvine onto CS - MS - A (wt \%).

Phase boundaries are for atmospheric pressure.

- = aphyrio lavas;

- = No. 142 (fable 16);

$\nabla \quad=$ olivines (Table 4$)$;

$\Delta$ = diopside-plagioclase piercing point (a), and olivineplagioclase piercing point (b);

口 = oumulus-enriched lavas;

- = augites (Table 6). 


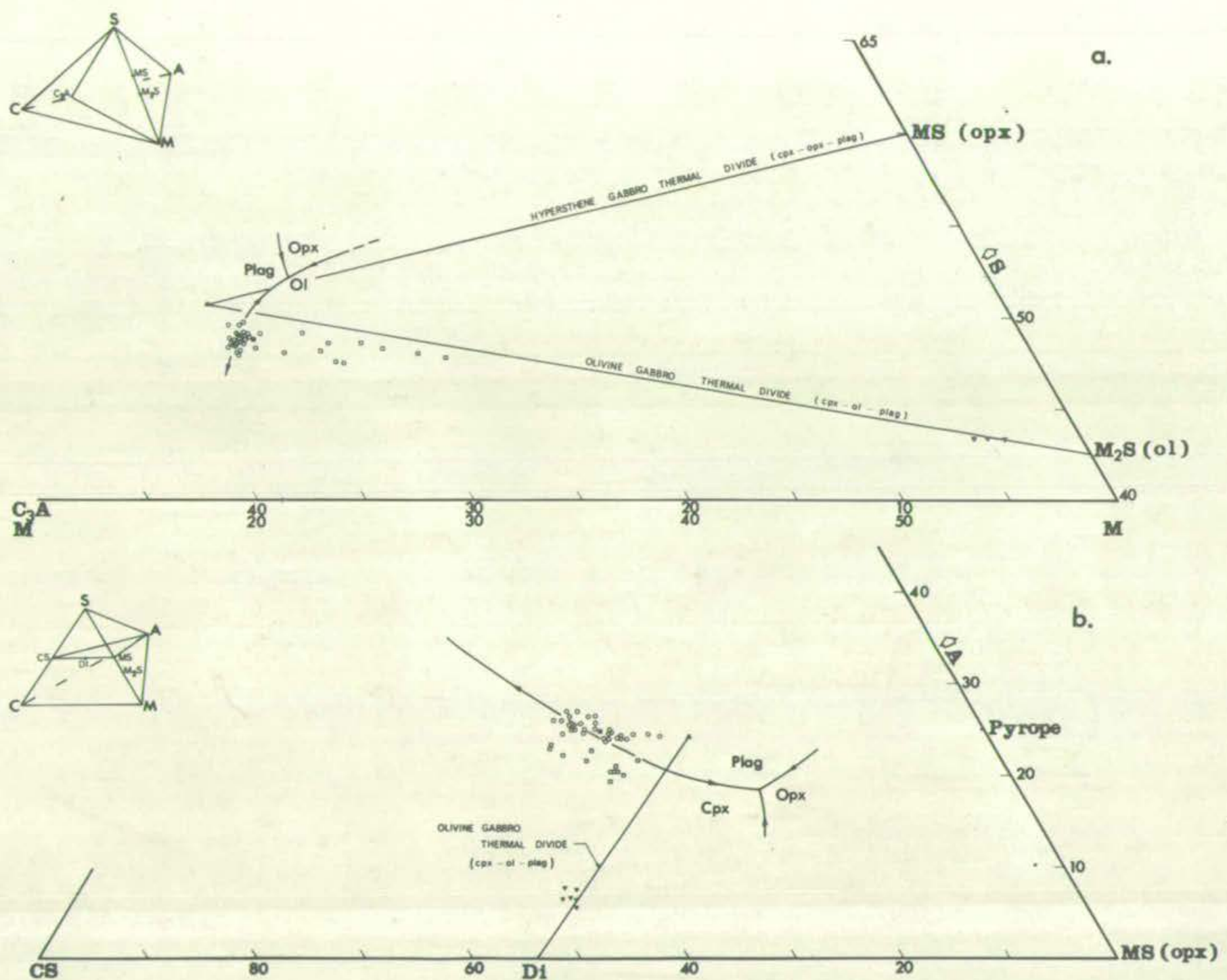


6.3. DIPEGRTWTIATION OF THE LA GRTLLE LAVAS

The La Grille lavas, like those of Kartala, show a range of phenocryst content ( 0 to 19 vol. $\%$ ) and Mgo content $(9.5$ to 20.0 wt. \%). It must be noted, however, that some olivine phenocrysts are skeletal and presumably crystallized from the liquid, same are xenocrystal and therefore added to the liquid, and some are ouhedral and may have either or both these origins. Thus, it is diffioult to evaluate the extent to which crystal-1iquid fractionation has contributed to the overall chemical variation in these lavas. This is especlally so because, unlike the Kartala situation, there is no obvious correlation between phenocryst and MgO content (Fig. 28a), normative olivine content (Fig. 29a) or any other chemical parameter determined in the present study. Burthermore, the La Grille chemical trends are poorly defined, with substantial scatter for most elements (see Figs. 13 and 23).

Although it is clear that the ollvine phenocrysts alone do not control the chemical variation in La Grille lavas, they must nevertheless make some contribution to 1t. The La Grille lavas might therefore be thought of as falling on a series of olivine control Ines which are offset by some additional process. If, as in the Kartala lavas, there is a simple addition-subtraction relation between phenocrysts and lava chemistry, one should be able to determine this secondary trend by recalculating the lava chemistry on a phenocryst-free basis. The results of this calculation for $\mathrm{SiO}_{2} / \mathrm{MgO}$ are shown In Fig. 31, the cloudiness of which indicates the absence of such a simple relation. It must be concluded that a large proportion of the "phenocrysts" in La Grille lavas are non-fractionating 
Table 16.

Representative lava compositions (recaloulated to $100 \%$ water-free)

\begin{tabular}{|c|c|c|c|}
\hline wo $\%$ & Kartala (No.142) & La Grille (average) & La Grille/Kartala \\
\hline $\mathrm{SiO}_{2}$ & $47 \cdot 2$ & $43 \cdot 6$ & 0.93 \\
\hline $\mathrm{TiO}_{2}$ & 2.65 & 2.01 & 0.76 \\
\hline $\mathrm{Al}_{2} \mathrm{O}_{3}$ & $14 \cdot 4$ & $12 \cdot 1$ & 0.84 \\
\hline $\mathrm{Fe}_{2} \mathrm{O}_{3}$ & 1.51 & & $2 \cdot 02$ \\
\hline $\mathrm{FeO}$ & $10 \cdot 8$ & $8 \cdot 8$ & 0.81 \\
\hline Mno & $\cdot 20$ & $\cdot 21$ & 1.05 \\
\hline $\mathrm{MgO}$ & $7 \cdot 1$ & $13 \cdot 4$ & $1 \cdot 89$ \\
\hline $\mathrm{CeO}$ & $11 \cdot 2$ & $12 \cdot 1$ & 1.08 \\
\hline $\mathrm{Na}_{2} \mathrm{O}$ & $2 \cdot 98$ & $2 \cdot 88$ & 0.97 \\
\hline $\mathrm{K}_{2} \mathrm{O}$ & $1 \cdot 40$ & $1 \cdot 14$ & 0.82 \\
\hline $\mathrm{P}_{2} \mathrm{O}_{5}$ & .51 & .56 & $1 \cdot 10$ \\
\hline Or & $7 \cdot 43$ & $6 \cdot 74$ & 0.91 \\
\hline $\mathrm{Ab}$ & $11 \cdot 89$ & $2 \cdot 54$ & 0.21 \\
\hline An & $23 \cdot 22$ & $16 \cdot 74$ & 0.72 \\
\hline $\mathrm{Ne}$ & $7 \cdot 76$ & $11 \cdot 84$ & $1 \cdot 52$ \\
\hline Di & $25 \cdot 55$ & $31 \cdot 78$ & $1 \cdot 24$ \\
\hline 01 & $15 \cdot 39$ & $20 \cdot 77$ & $1 \cdot 35$ \\
\hline Mt & $2 \cdot 28$ & $4 \cdot 44$ & 1.95 \\
\hline$I \mathrm{Im}$ & $5 \cdot 23$ & 3.82 & 0.73 \\
\hline $\mathrm{Ap}$ & $1 \cdot 26$ & $1 \cdot 33$ & 1.05 \\
\hline $\mathrm{Rb}$ & 30 & 40 & $1 \cdot 33$ \\
\hline $\mathrm{Cu}$ & 69 & 78 & $1 \cdot 13$ \\
\hline Sr & 538 & 608 & $1 \cdot 13$ \\
\hline $\mathrm{Ba}$ & 467 & 711 & 1.52 \\
\hline $\mathrm{Zn}$ & 109 & 92 & $\cdot 84$ \\
\hline $\mathrm{Zr}$ & 217 & 188 & .87 \\
\hline
\end{tabular}


phenocrysts, and that the bulk chernistry might represent original liquid compositions.

Projections of the La Grille lavas in the C.M.A.S. system (Fig. 32) retaln the cloudiness shown in the variation diagrams (esp. Fig. 32a). The elongation of the trend away from orthopyroxene in FIg. $32 b$ has no petrological significanee, being the result of distortion caused by the obliquicy of the plane to the olivine projection lines (see insert in Fig. 30b). There is no correspondence between the compositions of these lavas and the low pressure cotectios, and it is concluded that the chemistry of the La Grille lavas cannot therefore be explained by any low-pressure fractionation processes. It follows that some high-pressure process must be responsible, except for the relatively insignificant effects due to near-surface fractionation of olivine phenocrysts. It will be the purpose of the following chapter to try to elucidate the nature of such processes. Because of the lack of correlation between phenocryst content and chemical composition, one cannot assume that the most basic La Grille aphyric lava (No. 178, with $11 \cdot 0 \% \mathrm{MgO}$ ) represents any unique liquid composition. For example, No. 54, recalculated as phenoeryst-free, contains $13.5 \% \mathrm{MgO}$, and this must be taken as representative of the groundmass (11quid) composition of this rock. However, the apparently nomal distribution of both chemical compositions (Figs. 13 and 21) and phenoeryst contents (FIg. 9) of these rocks Indicates that an average composition can probably be taken as representative of the overall chemistry. This average is given in Appendix D, and recalculated as water-free in Table 16. 


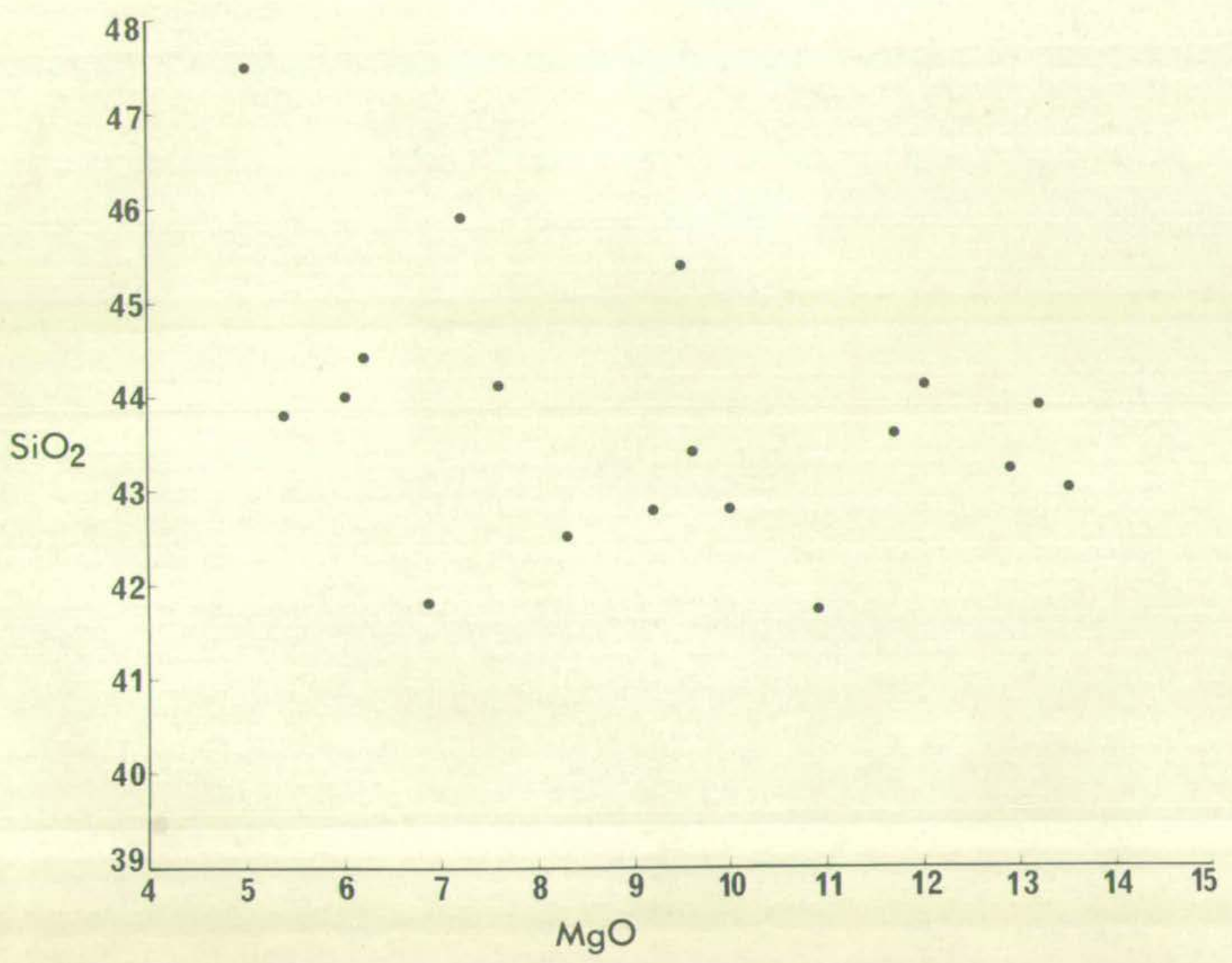


Fig. 32.

Projeations of La Grille lava compositions

in the C.M.A.S. system.

See FIg. 30 for details of method.

a. projection from diopside on to $\mathrm{C}_{3} \mathrm{~A}-\mathrm{M}-\mathrm{S}$ (wt.\%)

b. projection from olivine onto CS-MS-A (wt. $\%$ ).

The thin dashed lines enclose fields of Kartala lavas. 

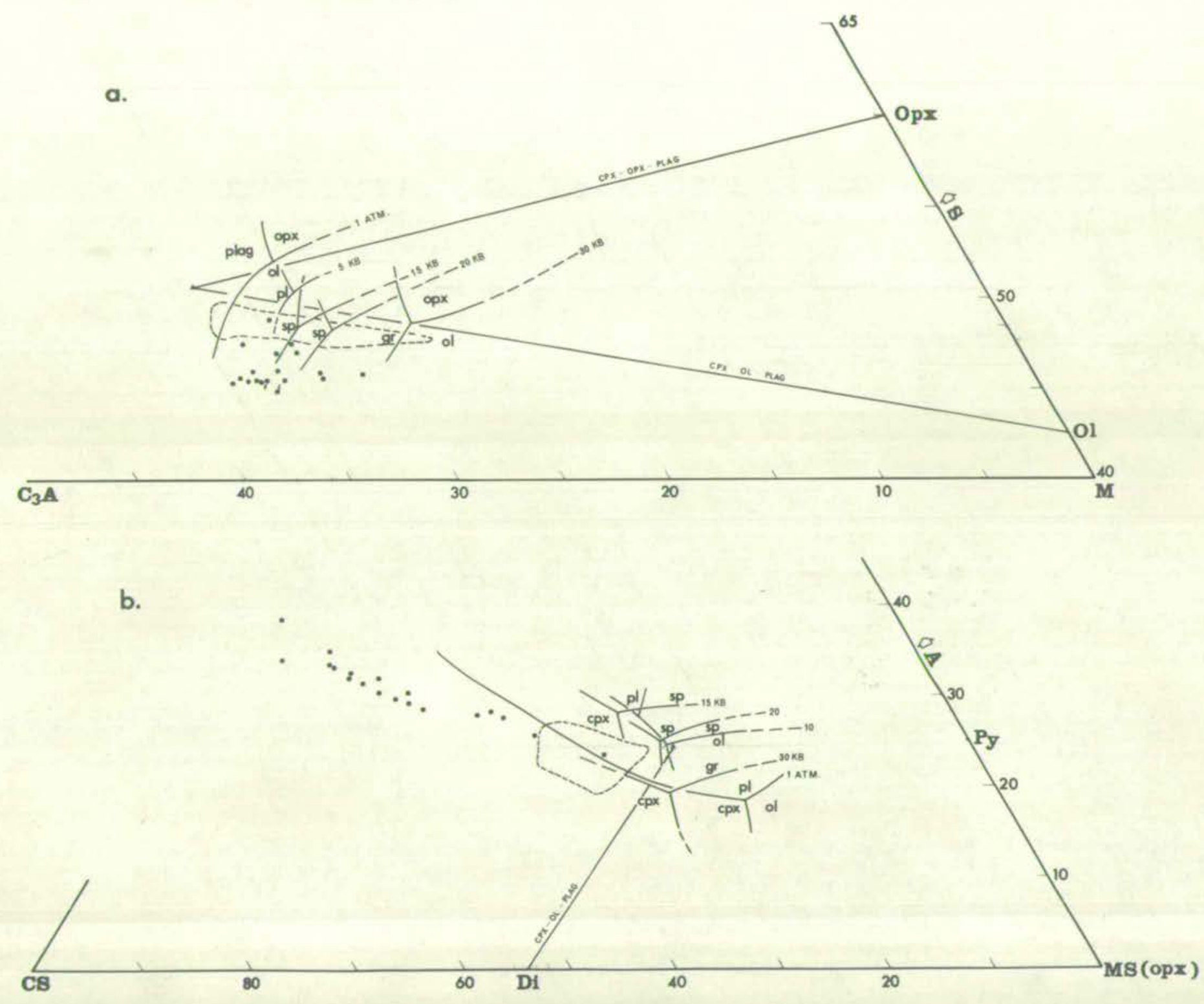
6.4. SUMMARY

Chemical variation within the Kartala lavas is directly attributable to fractional erystallization of olivine and augite in shallow magna reservoirs.

Chemical variation within the La Grille lavas is not explicable in terms of fractional crystallization of the olivine phenocrysts alone, and is thought to result from some additional process operating at high pressures. 


\section{FORMATION OF THE LAVAS}

7.1. INTRODUCTION

Assuming that the lavas of Grande Comore originate by partial melting of the upper mantle, a knowledge of the composition and physico-chemical behaviour of the upper mantle is essential in the understanding of their petrogenesis. The purpose of this chapter is to suggest a reasonable composition for the upper mantle, and outline means by which these lavas could have been produced from it.

7.2. UPPER MANTLE COMPOSITION

7.2.1. Major elements

It is known that various physical properties of the upper mantle are consistent with hypotheses that it consists of peridetite, eclogite, or some combination of both (e.g. Birch, 1960; Simmons, 1964). Recent studies by Press (1969) favour the suggestion that eclogite compositions are predominant, at least in the sub-oceanic mantle. However, experimental petrologists (e.g. Yoder and Tilley, 1962; Green and Ringwood, 1967) have argued strongly against an eclogitic upper mantle, devoting most of their attention to the experimental study of peridotite compositions.

Theoretical estimates of the upper mantle composition have also been based on terrestrial heat flow data and the cosmic abundance patterns of the elements (Macdonald, 1959; Urey, 1952; Hurley, 1957, 1968a, b; Lovering, 1958; Clark and Ringwood, 1964). However, the results of such estimates must be treated with caution, since they are entirely dependent upon the initial assumptions made. For 
example, the interpretations of terrestrial heat flow data would differ according to whether or not one assumed mantle convection. The validity of meteorite analogies depends, not only on whether representative meteorite compositions are obtainable, but more importantly on whether primitive solar abundances were maintained during earth formation. This, in the opinion of, for exemple, Turekian and Clark (1969) is likely not to have been so.

Some petrologists consider the relative abundances of different ultrabasic inclusions in basic lavas and kimberlites to be indicative of their abundance at depth, and consequently a reflection of mantle composition (Harris, et al., 1967; Davidson, 1967; 0'Hara, 1967, 1968; O'Hara and Yoder, 1967; Kutolin, 1970). Such arguments, like those based on meteorite analogies, must be treated with caution. For instance, 0 Hara (1967, p. 347) concludes that crystal cumulates in basalts "can be expected to occur alone and more frequently (than unmodified mantle fragments) because of their greater availability and the smaller increase in rate of flow necessary for the elutriation of such loosely attached material". In contrast, Harris et al. (1967, p. 6361) argue that the nodules cannot be cumulates because their mineral compositions are different from those in basalts, and the nodules are similar in composition and mineralogy irrespective of the rook type in which they occur.

An alternative approach to obtaining information on mantle composition from the basaltic lavas and ultrabasic inclusions involves the determination of their phase relations under probable mantle conditions, in order to show which inclusions, if any, are capable of yielding basaltic liquids upon partial melting. It has been shown 
that basaltic liquids can be derived from a range of basic and ultrabasic rocks, including gabbro, eclogite, pyroxenite, amphibolite, pyroxene amphibolite (Yoder and Tilley, 1962), spinel Iherzolite (Kushiro, et al., 1968) garnet Therzolite (0'Hara and Yoder, 1967), and a variety of synthetic peridotites (Bowen and Schairer, 1935; Reay and Harr1s, 1964; Green and Ringwood, 1967).

Some of the petrogenetic hypotheses formulated as a result of these studies appear to have exceeded the limits of what can be deduced from the experimental data, and are consequently difficult to evaluate until further experimental data become available. Examples include hypotheses involving wall-rock reaction (Harris, 1957; Green and Ringwood, 1967; Kushiro, 1968), or volatile transport (Bailey, 1964), whioh are to be entertained only after eliminating the relatively simpler hypotheses involving partial melting or fractional orystallization.

From phase diagrams constructed in the C.M.A.S. system 0 'Hara (1968, 1970) dismissed many therzolites, including the various "pyrolites" of Green and Ringwood (1967), as possible mantle compositions on the grounds that their Al/Ca ratios were too low to yield the harzburgites and garnet harzburgites commonly found as inclusions in $\mathrm{k}$ imberlites. He concluded that in this respect only the garnet Therzolite inclusions found in kimberlite could be considered as possible unmodified mantle material, a result supported by the statistical approach of Harris, et al. (1967).

However, the arguments advanced by $0^{\prime H a r a}$ for making this cholce of mantle composition are critically dependent upon the position and 
orientation of the crystal-ilquid control plane relating to partial melting of a 4-phase peridotite in the phase diagrams used. This plane shifts with pressure, with composition of the residual crystals (orthopyroxene in particular), and with fractional melting (ef. Presnall, 1969). Since the extent and nature of such shifts are not well-defined by existing data, O'Hara's conclusions cannot be accepted in detail. In fact, there appears to be no compelling reason to reject any of the gamet peridotites plotted by 0'Hara (1968, Figs. 4, 5 and 6) as posstble compositions of unmodified mantle peridotite. This being so, the average of 15 gamet peridotite analyses glven by Carswell and Dawson (1970, Table 3) is taken as representative of the major element composition of unmodifled mantle peridotite (see Table 17), although it is realized that this is only a first approximation, since the upper mantle may in fact be chemically inhomogeneous.

\subsubsection{Trace elements}

As the partition coefficients between crystals and liquid are unknown for trace elements at high pressures, one can only speculate as to their behaviour during partial melting of the upper mantle. Gast (1968) and Griffen and Murthy (1969) have indicated that $\mathrm{Ba}$, Sr, $K$, and $\mathrm{Rb}$ are highly concentrated in the liquid phase during the initial stages of partial melting of peridotitic compositions. This, by definition, is true of any incompatible element. Consequently, any mantle fragment brought up as xenolithic material would be severely depleted in incompatible elements if it had undergone only very little partial melting, and any such xenoliths have little chance 
of revealing true mantle concentrations. On the other hand, there is also a chance of these inclusions being contaminated by the enclosing magna, with a resulting increase in the concentrations of incompatible elements, especially in the case of kimberlitic magmas which are highly enriched in these elements (of. Harris and Middlemost, 1970). For example, the secondary phlogopite in many inclusions (see Nixon, et al., 1963; Carswell and Dawson, 1970) must reflect the addition of $K$. Even if data existed for inclusions without secondary phlogopite, carbonate, or serpentinfte, it could still not be trusted with regard to the incompatible elements which do not form a discreet phase (cf. Griffen and Murthy, 1969, pp. 1395-1396). One is consequently left with the altermative of making some hypothetical estimate of the concentrations of incompatible elements in the upper mantle.

The concentrations of $\mathrm{K}, \mathrm{Rb}, \mathrm{Sr}$, and $\mathrm{Ba}$ accepted by the present writer as representative of the upper mantle are given in Table 17. These were calculated by Griffen and Murthy (1969, Table 6) from concentrations in the individual minerals of garnet peridotite, which were combined in the proportions of olivine, 65\%:clinopyroxene, 12\%: orthopyroxene, 13\%: garnet, $10 \%$, as calculated for the average garnet Iherzolite by Harris, et al. (1967), assuming the absence of hydrous phases such as phlogopite or amphibole. The concentrations of $\mathrm{Zr}, \mathrm{Zn}$, and Cu (Table 17) are taken from Vinogradov (1962), and represent a variety of ultrabasic rock types. 


\section{Table 17}

Hypothetical upper mantle garnet peridotite composition (after Carswell and Dawson (1970, Table 3).

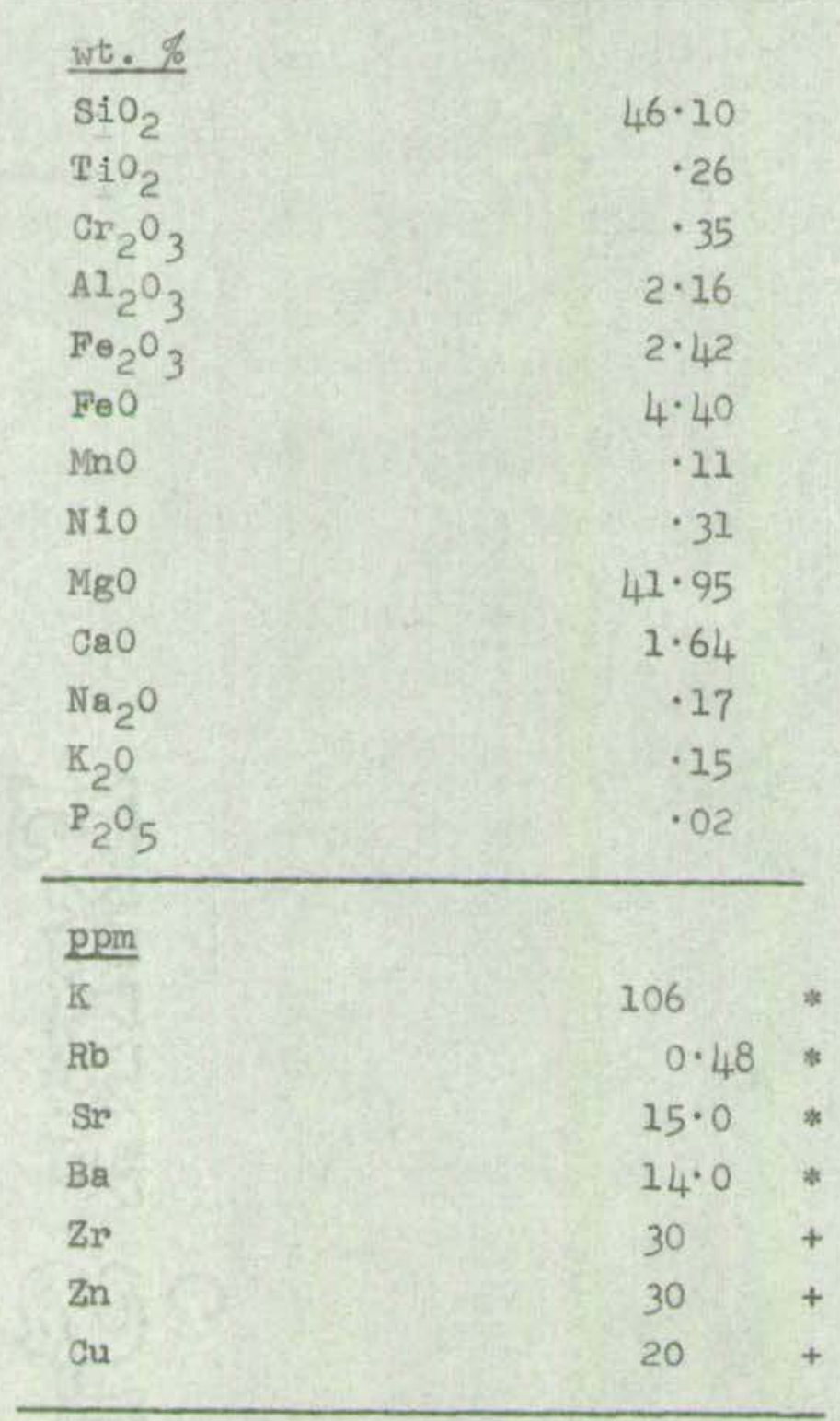

*

Griffen and Murthy (1969, Table 6).

+ Vinogradov (1962). 
Table 18

Thrlchment of minor and trace elements relative to the postulated upper mantle concentrations.

\begin{tabular}{|c|c|c|c|c|c|}
\hline wt. \% & $\begin{array}{l}\text { Conc. } \\
\text { Mantie }\end{array}$ & $\begin{array}{l}\text { Kartala } \\
\text { Conc. }\end{array}$ & $\left(\mathbb{N o}_{\mathrm{E}} .142\right)$ & $\begin{array}{l}\text { La Grille } \\
\text { Cone. }\end{array}$ & $\begin{array}{c}(\text { mean }) \\
\mathrm{E}\end{array}$ \\
\hline $\mathrm{TiO}_{2}$ & 0.26 & $2 \cdot 61$ & 10 & 2.00 & 8 \\
\hline $\mathrm{P}_{2} \mathrm{O}_{5}$ & 0.02 & 0.52 & 26 & .56 & 28 \\
\hline $\mathrm{Na}_{2} \mathrm{O}$ & 0.17 & 2.96 & 17 & $2 \cdot 86$ & 17 \\
\hline \multicolumn{6}{|l|}{$\mathrm{ppm}$} \\
\hline K & 106 & 11,450 & 108 & 9,296 & 88 \\
\hline $\mathrm{Rb}$ & 0.48 & 30 & 63 & 40 & 83 \\
\hline Sr & 15 & 530 & 35 & 600 & 40 \\
\hline $\mathrm{Ba}$ & 14 & 460 & 33 & 703 & 50 \\
\hline $\mathrm{Zr}$ & 30 & 213 & 7 & 186 & 6 \\
\hline $\mathrm{Zn}$ & 30 & 107 & 4 & 90 & 3 \\
\hline $\mathrm{Cu}$ & 20 & 68 & 3 & 77 & 4 \\
\hline Average & & - & 47 & - & 51 \\
\hline wt. \% & & Kartala & (No.18) & La Grille & 0 (No.54) \\
\hline $\mathrm{T}^{10} \mathrm{O}_{2}$ & & $1 \cdot 49$ & 6 & 1.67 & 6 \\
\hline $\mathrm{P}_{2} \mathrm{O}_{5}$ & & .23 & 12 & .55 & 28 \\
\hline $\mathrm{Na}_{2} \mathrm{O}$ & & 1.56 & 9 & $1 \cdot 88$ & 11 \\
\hline \multicolumn{6}{|l|}{ ppm } \\
\hline K & & 3,980 & 37 & 7,700 & 73 \\
\hline $\mathrm{Rb}$ & & 10 & 21 & 26 & 54 \\
\hline $\mathrm{Sr}$ & & 245 & 16 & 495 & 33 \\
\hline $\mathrm{Ba}$ & & 200 & 14 & 525 & 37 \\
\hline $\mathrm{Zr}$ & & 110 & 4 & 157 & 5 \\
\hline $\mathrm{Zn}$ & & 104 & 4 & 90 & 3 \\
\hline $\mathrm{Cu}$ & & 73 & 4 & 80 & 4 \\
\hline *Average & & - & 18 & - & 39 \\
\hline
\end{tabular}

$$
E=\frac{\text { concentration in lava }}{\text { concentration in mantle }} \text {. }
$$

* $\mathrm{TiO}_{2}, \mathrm{Zr}, \mathrm{Zn}$ and $\mathrm{Cu}$ excluded from calculation of average $\mathrm{E}$. 


\subsection{ENRICHMENT FACTORS}

The enrichment of minor and trace elements relative to the upper mantle is shown for both Kartala and La Grille lavas in Table 18. Using the most basic liquid (No. 142) as representative of Kartala lavas, it is seen that enrichment factors (E) range from 17 ( for $\mathrm{Na}_{2} \mathrm{O}$ ) to 108 (for $\mathrm{K}$ ), with an average of 47. The enrichment factors for the average of $\mathrm{La}$ Grille lavas range from 17 (for $\mathrm{Na}_{2} \mathrm{O}$ ) to 88 (for $\mathrm{K}$ ), with an average of 51. The low enrichment factors for $\mathrm{TiO}_{2}, \mathrm{Zr}, \mathrm{Zn}$, and $\mathrm{Cu}$ (all less than 10) indicate that they cannot be considered as incompatible elements, 1. $\theta$. they were retained by some solld phase or phases, during the development of these lavas. If one assumes that the incompatible elements are perfectly incompatible, or even that they have liquid/crystal distribution coefflcients greater than 10 (ce. Gast, 1968), the effect of increasing or decreasing the relative proportions of liquid to solld is merely one of dilution or concentration. For example, if the volume of liquid were doubled (by increased partial melting or crystal fractionation), the concentrations of incompatible elements would be halved; if the volume of liquid were halved (by crystal accumulation), the concentrations of incompatible elements would be doubled. These effects can be expressed by the simple equation

$$
\mathrm{V}=100 / \mathrm{E}
$$

where $\mathrm{V}$ is the volume of liquid remaining after a particular process, and $\underline{E}$ is the factor by which the incompatible elements are enriched during the process. This equation is used to calculate degrees of partial melting and crystal fractionation in subsequent discussions. 
Some indication of the effect of low-pressure orystal accumulation on the enrichment factors of minor and trace elements are given in Table 18 for the most basic lava of each volcano. The average enrichment factor of 18 for the most basic Kartala lava (No. 18, Table 18) corresponds to an accumulation of $58 \%$ phenocrysts In a liquid with similar concentrations of incompatible elements to No. 142 (Table 18), as compared to an actual value of $40 \%$ phenoerysts in the lava. The average enrichment factor of 39 for the most basio lava of La Grille (No. 54, Table 18) corresponds to a dilution of the average La Grille lava by $25 \%$ phenocrysts, as compared to $15 \%$ phenocrysts in the lava.

7.4. ORIGIN OF THE KARTALA LAVAS

7.4.1. Introduction

The C.M.A.S. projections of Kartala lavas shown in Fig. 30 (Chapter 6) are schematically reproduced in Fig. 33. As discussed In section 6.3., the obliquity of projection from olivine onto the plane CS-MS-A causes the projected composition fields to be distorted and elongated in a direction away from MS (orthopyroxene). Therefore, In Flg. 33b, the flelds of Kartala aphyric and cumulus-enriched lavas (1.e. those with more than $7.0 \% \mathrm{MgO}$ ) are shown as circles. The diameters of these ofrcles are taken as the width of the elongated fields that are shown in Fig. 30.

The phase boundaries shown in Fig. 33 are taken from O'Hara's (1968) Figs. 4 and 6. The hypothetical mantle composition plotted as $\underline{M}$ is that given in Table 17. The control planes for advanced partial melting of $\underline{M}$ are constructed for 15,20 , and $30 \mathrm{~kb}$ (Fig. 33b), 
and the reader is referred to O'Hara (1970) for a detailed discussion of such planes. Unfortunately, they cannot be precisely positioned due, in particular, to a lack of information on appropriate orthopyroxene compositions, and may be only schematically correct. The orthopyroxenes used in Fig. 33b to construct the 15 and $20 \mathrm{~kb}$ control planes are those coexisting with clinopyroxene and Ilquid only (1.e. no olivine) at $13.5 \mathrm{~kb}, 1290^{\circ} \mathrm{C}$ and $18 \mathrm{~kb}, 1335^{\circ} \mathrm{C}$, respectively, as given by Green and Ringwood (1967, Table 9). The control plane at $30 \mathrm{~kb}$ is constructed from O'Hara's (1968) Fig. 5. 7.4.2. Generation of Kartala lavas.

Because of the likelihood that basaltic magmas will fractionate at least olivine during their ascent (Davis and Schairer, 1965; O'Hara 1965, 1968), the Kartala magmas at depth may be assumed to have been richer in normative olivine than any liquids which reach the surface. Furthermore, they had probably attained their nepheline-normative character before reaching a depth of about $25 \mathrm{~km}$ (equivalent to a pressure around $8 \mathrm{~kb}$ ), since the olivine-clinopyroxene-plagloclase thermal divide is operative at lower pressures (Yoder and Tilley, 1962). Hence, it is reasonable to assume that the Kartala lavas were derived from more picritic basic magmas formed at pressures above $8 \mathrm{~kb}$.

It can be seen from Fig. 33 that nepheline-normative magmas can be produced by direct partial melting at pressures between approximately 10 and $25 \mathrm{~kb}$. However, Fig. 33b shows that such magmas will have Al/Ca ratios too high to produce the Kartala lavas without their being modified by some additional process such as crystal 
Fig. 33 .

C.M.A.S. projections of the Kartala and La Grille lava compositions, schematically reproduced from Figs. 30 and 32. Phase boundaries from 0 'Hara (1968).

Arrows indicate directions of decreasing temperature.

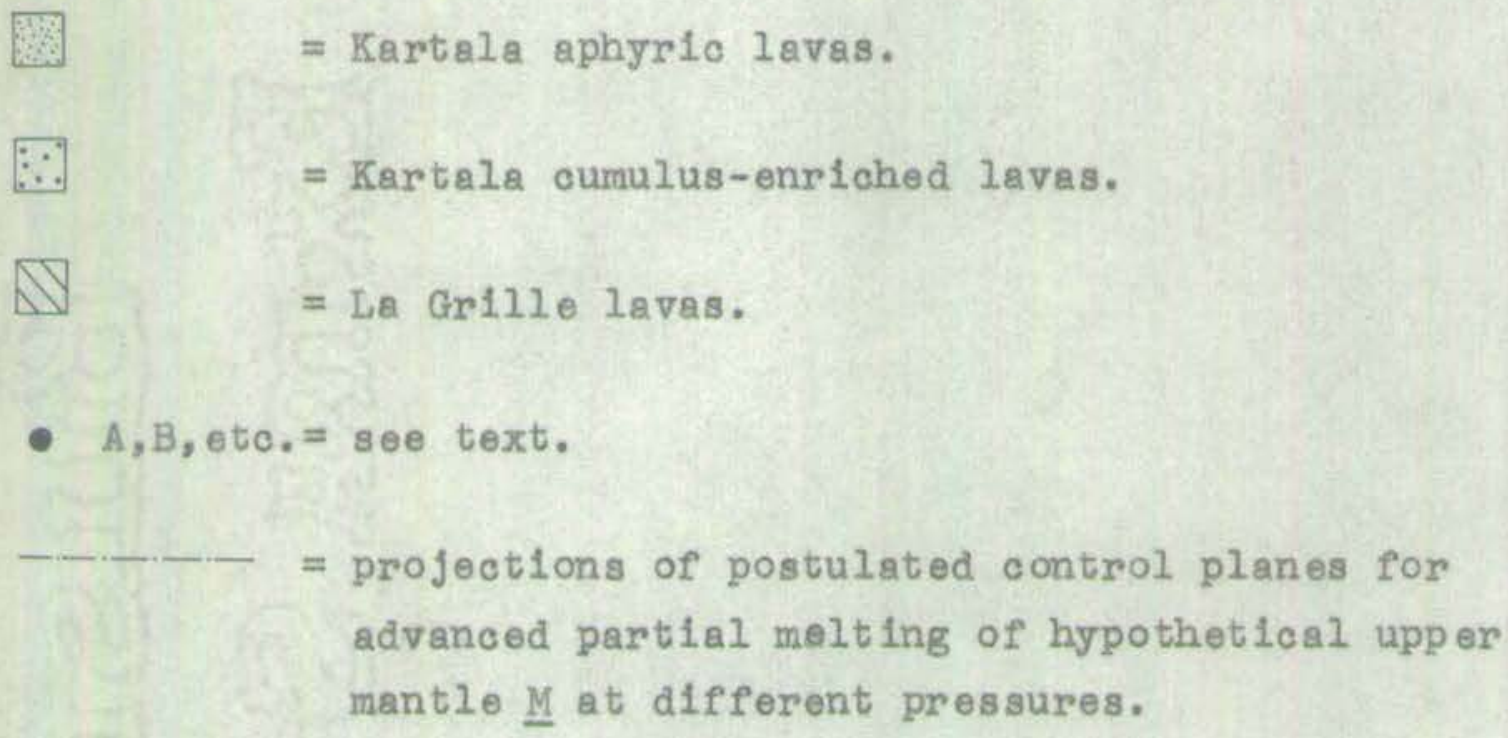



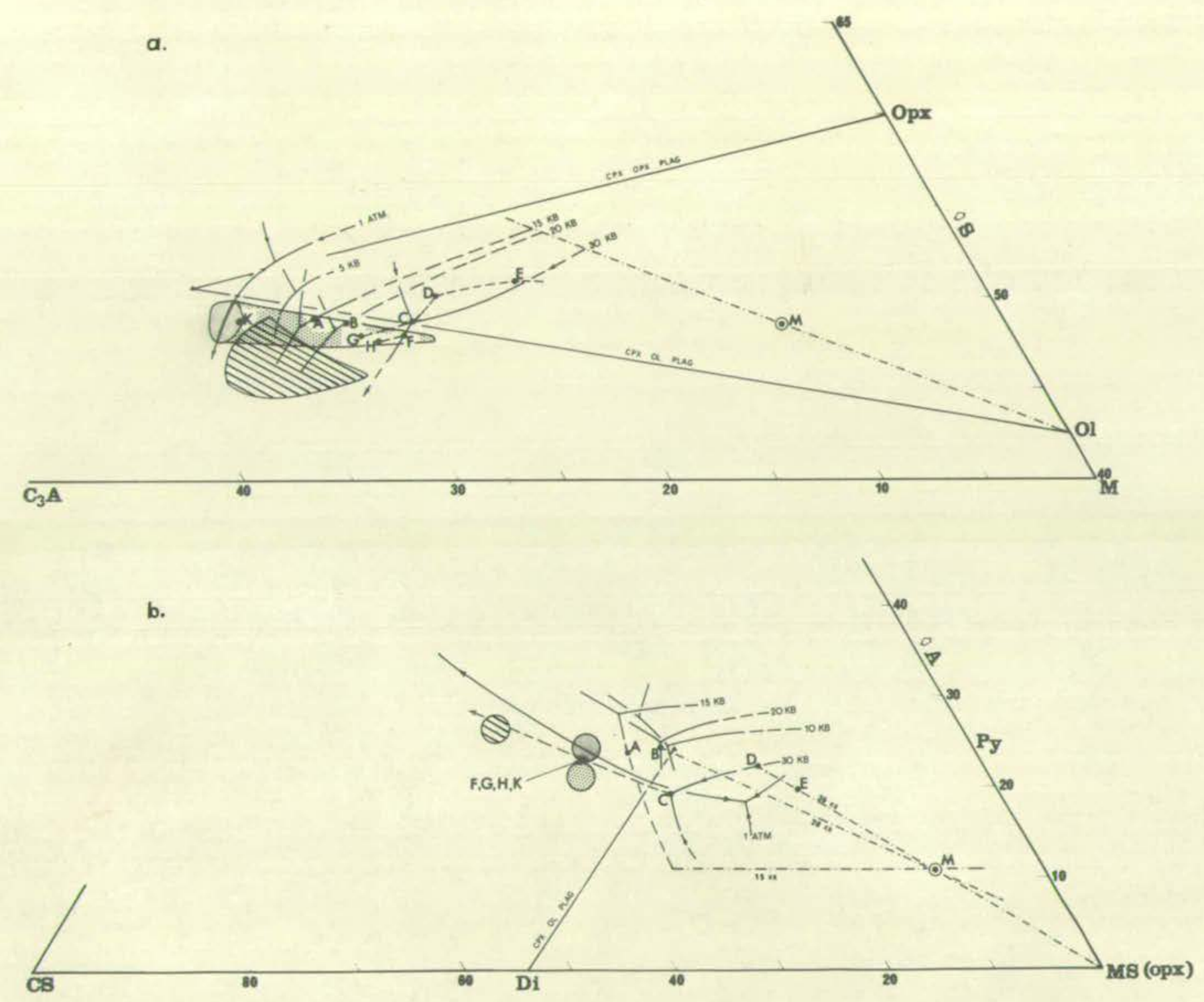
fractionation. For example, if partial melting were advanced to the stage where liquids $\underline{A}$ or $\underline{B}$ were formed at 15 or $20 \mathrm{~kb}$ respectively (Fig. 33), these liquids could only yield the Kartala lavas by rapid eruption to pressures close to one atmosphere, where subsequent gabbro fractionation along the olivine + diopside + plagioclase + liquid cotectic could yield the appropriate compositions. However, it has been show that plagioclase phenocrysts are very pare in the Kartala lavas, and the trace element and rare-earth data (Eu in partioular) do not suggest that any substantial plagioclase fractionation has occurred during their development. An alternative possibility is that partial melting occurred at higher pressures, say $30 \mathrm{~kb}$, during which increasingly advanced partial melting should result in the loss of olinopyroxene (Fig. 33b) followed by the loss of garnet (Fig. 33a). Because of this early loss of clinopyroxene, the path of further melting along C-D-E (Fig. 33b) w1ll not be on the boundary of the diopside primary phase volume, and therefore cannot be accurately projected in Fig. 33a. However, this path is schematically shown as the line C-D-E in Fig. 33a, and the point E is arbitrarily taken as representative of a magma produced by advanced partial melting (involving loss of both elinopyroxene and garnet) at $30 \mathrm{~kb}$. If this magma were permitted to fractionate at any pressures above $25 \mathrm{~kb}$, it would follow a path such as $\underline{E-D-C-F}$, fractionating harzburgite from $\underline{E}$ to $\underline{D}$, garnet harzburgite from $\underline{D}$ to $\underline{C}$, and garnet wehrlite (olivine eclogite) from $\underline{\mathrm{C}}$ to $\underline{\mathrm{F}}$.

If olivine undergoes reaction in the equilibrium olivine + 
clinopyroxene + gamet + Iiquid, as suggested by O'Hara and Yoder (1967, p. 106) and O'Hara (1968, pp. 75-76), the residual 11quid would follow some path such as $\underline{\mathrm{C}-\mathrm{G}}$ or $\underline{\mathrm{F}-\mathrm{H}}$ across the gamet + elinopyroxene + 1iquid surface (Fig. 33a), 1.e. undergo eclogite fractionation instead of garnet wehrlite fractionation. Like the path $C-D-E$, however, the position of the residual liquids resulting from eclogite fractionation is not accurately known, and even if it were, It could not be adequately projected from olivine (Fig. 33b), a phase not involved in the equilibrium. Nevertheless, it is almost certain that elther eclogite or garnet wehrlite fractionation at about $30 \mathrm{~kb}$ will inorease the nepheline-normative character of the liquid, regardless of the exact position of $\underline{\mathrm{C}-\mathrm{G}}$ or $\underline{\mathrm{F}}-\mathrm{H}$.

Considering now the effects of polybaric fractionation, as might occur during ascent of these magmas, a variety of fractionation paths are possible. For example, if the rate of ascent were just such that the residual liquid remained on the clinopyroxene + olivine + aluminous phase + liquid ootectio (Fig. 33), there could be a sequence of cumulates consisting of garnet wehrlite or eclogite, followed at lower pressures by spinel lherzolite or spinel wehrlite (or both in sequence), followed at still lower pressures by gabbro. (In this respect, it should be noted that eclogite fractionation need not be isobaric, but merely occurring at pressures above about $25 \mathrm{~kb}$.) Such Ilquids, however, would not have satisfactory $\mathrm{Al} / \mathrm{Ca}$ ratios without the gabbro fractionation, a process dismissed above, and such a sequenee of events is not considered likely in the case of Kartala lavas. 
Alternatively, if the magma was brought rapidly to shallower depths so that 1 was not capable of maintaining equilibrium with so many solid phases, it would fractionate correspondingly fewer of them, if any. Examples of such extremely rapid ascent with little or no fractionation have been postulated by Clarke (1970) for basalts In the Baffin Bay area, and by Jamieson $(1966,1969)$ for the Nuanetsi basalts of Rhodesia. With regard to the Kartala lavas, it can be seen from Flg. 33b that they have compositions which lie on the cotectios at atmospheric pressure, at $30 \mathrm{~kb}$, possibly at higher pressures where the positions of phase boundaries are unknown, but not at any intermediate pressures. In this respect they are explicable in terms of fairly rapid ascent from $100 \mathrm{~km}$ or more so that they preclpitate only olivine or olivine + clinopyroxene (wehrlite), resulting In Ilquids such as $\underline{K}$ on the low-pressure cotectic (F1g. 33), equivalent in composition to No. 142 (Table 16). Collection of this magma in shallow magma chambers, as proposed in Section 6.2 , would permit the precipitation of olivine and augite, producing the range of cumulusenriched and aphyric lavas presently observed.

There is no difficulty, therefore, in explaining the major element chemistry of Kartala lavas by processes involving anhydrous crystal-1iquid equilibria, and it remains to be shown whether the minor and trace element chemistry can be similarly accounted for. It has been proposed by Gast (1968) and 0'Hara (1968) that wide ranges in the relative and absolute concentrations of incompatible elements in the liquid phase can bo produced by slight variation in the degree of partial melting, especially in the earliest stages of 
melting. Further changes in absolute coneentrations can be produced by variable amounts of erystal fractionation. With such flexibility, one need only assume the appropriate combination of partial melting and crystal fractionation to sult the observed data, and objective evaluations become difficult.

With reference to the enrichment factors shown in Table 18, the following are possible combinations of melting and fractionation, assuming that the 11quid E (Fig. 33) has similar enrichment factors to No. 18 (Table 18), since it plots in a similar position in Fig. 33. The average enrichment factor of 18 in such a liquid could be produced by, say, $10 \%$ partial melting and $50 \%$ fractionation of eclogite or wehrlite; or by $5 \%$ partial melting and no fractionation; or by $20 \%$ partial melting and $75 \%$ fractionation. Subsequent fractionation of $50 \%$ olivine \pm augite during ascent would result in the average enriahment faotor of 48 found in No. 142 (Table 18). (Seo Section 7.3. for the method of calculating these proportions.) Although any exact estimates of the relative importance of fractional erystallization or partial melting would be impossible, even if high pressure partition coefficients were known exactly (of. Schilling and Winchester, 1967; Gast, 1968) there is clearly no difficulty in producing the Kartala enrichment factors by these processes.

7.5. OR IGIN OF THE LA GRILLE LAVAS

7.5.1. Introduction

The close proximity of Kartala and La Grille voloanoes, and the overlap of La Grille lava compositions with those of Kartala, 
require consideration of the possibility that both groups of lavas have a common origin. Furthermore, the significance of ultramafic Inclusions in the La Grille lavas, but not those of Kartala, requires some consideration.

In spite of the overlap in chemistry of the lavas of the two voloanoes, it is useful to emphasize the differences between them. The La Grille lavas are not only more basic in average bulk composition, but the aphyric La Grille lavas are more basic than any from Kartala. This may mean that the La Grille lavas represent a greater degree of melting of peridotitic material in the source region, or that they have undergone less fractionation of ferromagnesian minerals during ascent, or some combination of both. If primarily due to the smaller degree of fractionation, then a faster rate of ascent is implied. Faster ascent of the La Grille lavas is also consistent with the elutriation of the large high density peridotite inclusions which they contain (see section 3.3.3.) If, as suggested by the vesicle volumes (Fig. 10) and water contents (Fig. 13), there was no significant difference in volatile content of either group of lavas, the gentler slopes of La Grille may also be taken to reflect lower viscosity resulting from higher temperatures, and therefore faster ascent, than the lavas of Kartala.

\subsubsection{Generation of La Grille lavas}

The La Grille lavas are shown schematically in the C.M.A.S. projections in Fig. 33 following the same procedure to remove distortion from the olivine projection (Fig. 33b) as described for Kartala, Fig. 33 shows that the La Grille major element chemistry 
can be derived from the same primary magma as that of the Kartala lavas by greater fractionation of eclogite or garnet wehrlite (olivine eclogite) at $30 \mathrm{~kb}$. Furthemore, eruption at different stages of this high-pressure fractionation would account for the overlap of La Grille and Kartala lava chemistry, specimens such as No. 57 (see Section 5.7.2.) having undergone simflar degrees of highpressure fractionation to Kartala lavas. Such a process is consistent with the higher average incompatible element enrichment factors for the La Grille lavas (Table 18). The average of 40 for the most basic La Grille lavas (No. 54, Table 18) compared to 18 for the most basic Kartala lava (No. 18, Table 18) is equivalent to correspondingly greater high-pressure fractionation, depending upon the degree of partial melting. For example, with $20 \%$ partial melting, $75 \%$ crystal fractionation would produce the Kartala enrichment factors, and $87 \%$ fractionation would produce the La Grille enrichment factors. (see Section 7.3. for method of calculation.) Although this hypothesis is attractive in its simplicity, the degree of high-pressure fractionation required by the incompatible element enrlchment factors seems excessively large. It also does not explain why the two types of lava are erupted from separate centres $35 \mathrm{~km}$ apart. Thus, it is necessary to subject this hypothesis to a more rigorous test.

As discussed in Section 5.4 .1 , it is essential to the concept of incompatible elements that they be excluded from any precipltating phases, and thus all be passively concentrated in the liquid in equal proportions, with a resulting linear relation between any two such elements. Therefore, if the concentrations of incompatible elements 
in La Grille and Kartala lavas deffer because of eclogite or wehrlite fractionation, there must be a linear relation between any two of them.

Because Ba has enrichment factors close to the average for each group (Table 18), and because of its importance in discriminating between them (Appendix D), it is used as an index of incompatibility in Fig. 34, in which various trace and minor elements are plotted against 1t. The same features are seen by plotting, for example, $\mathrm{K}_{2} \mathrm{O}$ against each of these elements. This diagram shows that all elements regarded as incompatible in the Kartala lavas have more or less linear distributions (see Appendix D for correlation coefficients), in accordance with the petrogenetic scheme outlined in Section 7.4.2. Although roughly linear distributions are also apparent for the La Grille lavas, they tend to be more scattered than those of Kartala, as also reflected in the lower correlation coefflolents (Appendix D). The most Important feature of Fig. 34, however, is the offset of the flelds for each voleano, showing that the two magma groups cannot be simply related by the high pressure fractionation of any minerals towards which these elements were behaving in an ideally incompatible manner. Neither does the soatter of points within the La Grille flelds appear to be explicable in terms of the fractionation of such phases. It seems necessary, therefore, to investigate processes of deriving the La Grille lavas Independently from those of Kartala, as one would have expected from thelr geographical separation.

It has been shown by Gast (1968) that a range of enrichment factors is possible for $\mathrm{Ba}, \mathrm{Sr}, \mathrm{Rb}$, and $\mathrm{K}$ during the initial atages of 
Fig. 34 .

Concentration of some minor and trace elements v8. Ba in Kartala and La Grille lavas.

$$
\begin{aligned}
& =\text { Kartala } \\
-\quad & =\text { La Grille }
\end{aligned}
$$




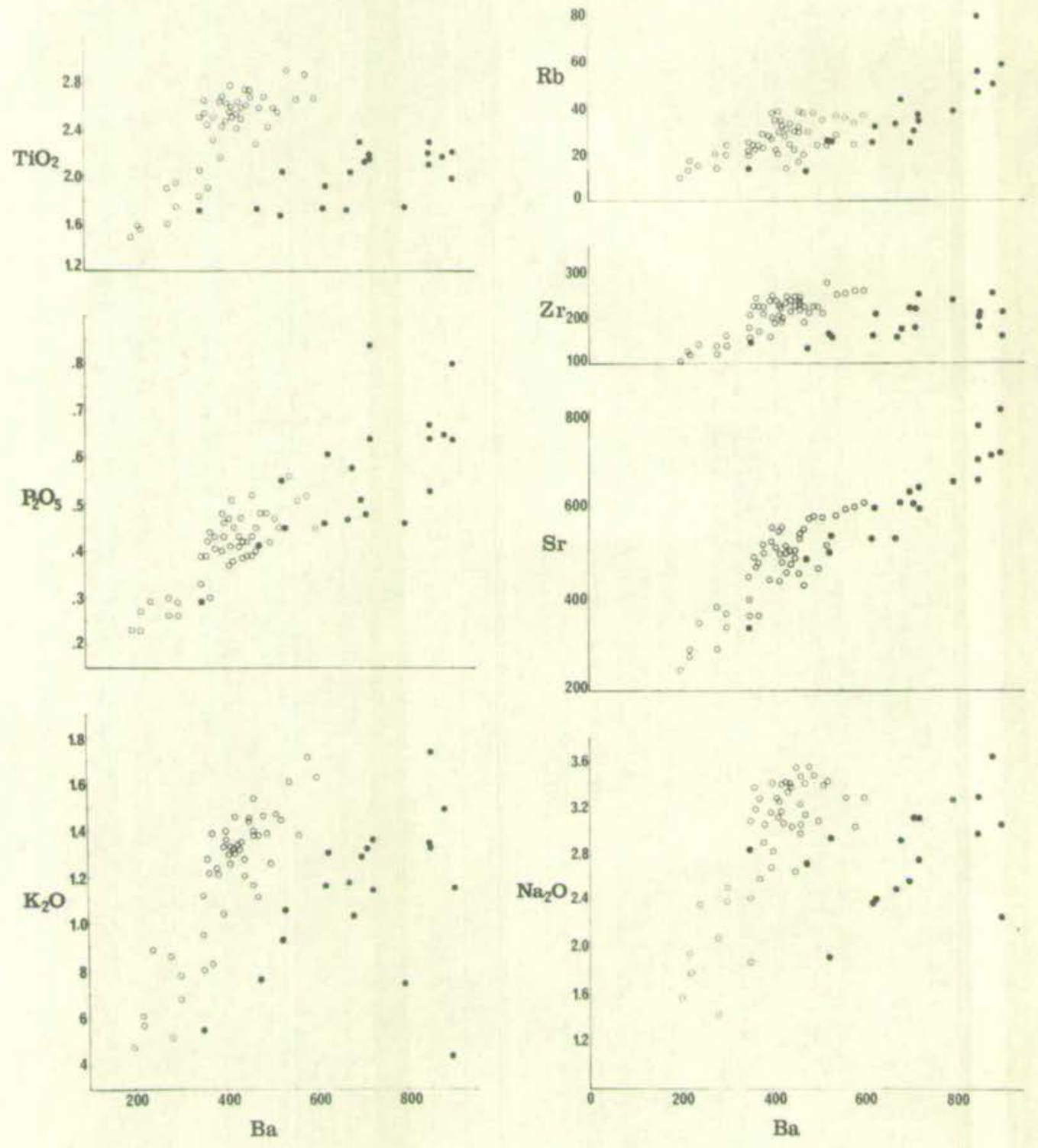


partial melting, 1.e. before they are completely concentrated. In the melt. With up to $10 \%$ partial melting, these enrichment factors are independently varlable to a much greater degree than they are with more edvanoed melting and resulting greater dilution. Thus, with such low degrees of partial melting, no definite relation between any two incompatible elements can be predicted. Consequently, the La Grille lavas could have obtained their imprint of inoompatible elements during the inftial stages of partial melting (less than $20 \%$ ), resulting in the apparently random scatter observed in diagrams such as Fig. 34.

Other processes involving fractionation or partial melting of hydrous phases such as phlogopite or amphibole have also been considered. These have been rejected, however, because the avallable trace element concentrations in such phases are not suitable, as outIned In detall by Gast (1968) and Wood (1968) (see Section 1.2.3.). Although there is no experimental data avallable regarding the effects of volatiles on trace elements, the available date for mejor elements (e.g. Morey and Hesselgesser, 1951; Luth and Tuttle, 1968), especially the $\mathrm{S1O}_{2}$ - $\mathrm{rich}$ nature of vapours in equilibrlum with silicates and silicate melts, suggest that volatiles were not important in the generation of these lavas. The hypotheses involving wallrook reaction (Green and Ringwood, 1967; Kushiro, 1968; Harris, 1957) are regarded as even more untestable than volatile transport, and cannot be dismissed or accepted on completely objective grounds. However, the inferred faster rate of ascent of the La Grille lavas suggests that they would have lower enrlohment factors than those of Kartala if wall-rook reaction during ascent had been the dominant 
prooess diotating their final trace element contents.

\subsection{PETROGENETIC SUMMARY}

In the light of the above analysis of the ohemistry and petrography of the Kartala and La Grille lavas, and accepting the phase diagrams constructed by $0^{\prime}$ Hara (1968), the following sequence of events, outlined in Fig. 35, seem to be reasonable explanations of their petrogenesis.

\subsubsection{Kartala lavas}

1. Partial melting of upper mantle of approximate composition $\underline{\underline{M}}$, at pressures of $25 \mathrm{~kb}$ or more, to form liquids represented by composition E, $1 . \theta$. with more than $10 \%$ partial melting.

2. Removal of liquid from equilibrium with mantle material, e.g. by coalescence into large pockets or gradual ascent.

3. Cooling of these liquids at pressures above $25 \mathrm{~kb}$ so that they might fractionate any or all of the following: harzburgite along $\underline{E-D}$, garnet harzburgite along $\underline{D-C}$, and either garnet wehrlite along $\underline{\mathrm{C}-\mathrm{P}}$ or eclogite along some path such as $\underline{\mathrm{C}-\mathrm{G}-\mathrm{Y}}$ or $\underline{\mathrm{F}-\mathrm{H}-\mathrm{Z}}$.

4. Interruption of this essentially isobario fractionation by rapid upward migration of magma, at such a rate as to prevent the precipltation of garmet or spinel, while olivine and possibly clinopyroxene do precipitate and sink, producing liquids of composition K.

5. Collection and cooling of $\underline{K}$ in shallow magma reservolrs to precipitate olivine and augite, resulting in the cumulus-enriched and complementary aphyric lavas that reach the surface. 
7.6.2. La Grille lavas

1. Partial melting of uppor mantle of approximate composition $\underline{M}$ at pressures of $25 \mathrm{~kb}$ or more, jielding liquids of composition C, 1.0. with less than $10 \%$ partial melting.

2. Cooling of this liquid at similarly high pressures to fractionate the following: garnet harzburgite at $\underline{C}$, garnet wehrlite along $\underline{\mathrm{C}-\mathrm{F}-\mathrm{X}}$ or eclogite along $\underline{\mathrm{C}-\mathrm{G}-\mathrm{Y}}$ or $\mathrm{F-H-Z}$.

3. Interruption of this essentially isobaric fractionation at different stages by rapid upward migration of the liquids, during which olivine, olinopyroxene, orthopyroxene and spinel are precipitated in variable proportions, some being retained as the ultrabasio inclusions (wehrlites, Iherzolites, and dunites) that are found in the La Grille lavas. 
Fig. 35.

Schemat1. representation in the C.M.A.S. system of the postulated sequence of processes involved in the development of Kartala and La Grille lavas.

Thin solid arrows represent compositional changes In the magmas resulting from polybaric fractionation (see text for phases involved) during ascent. Thin dashed arrows represent compositional changes In the magmas caused by low pressure fractionation and accumulation of olivine and augite during ascent. Other lines and symbols as for Fig. 33 . 

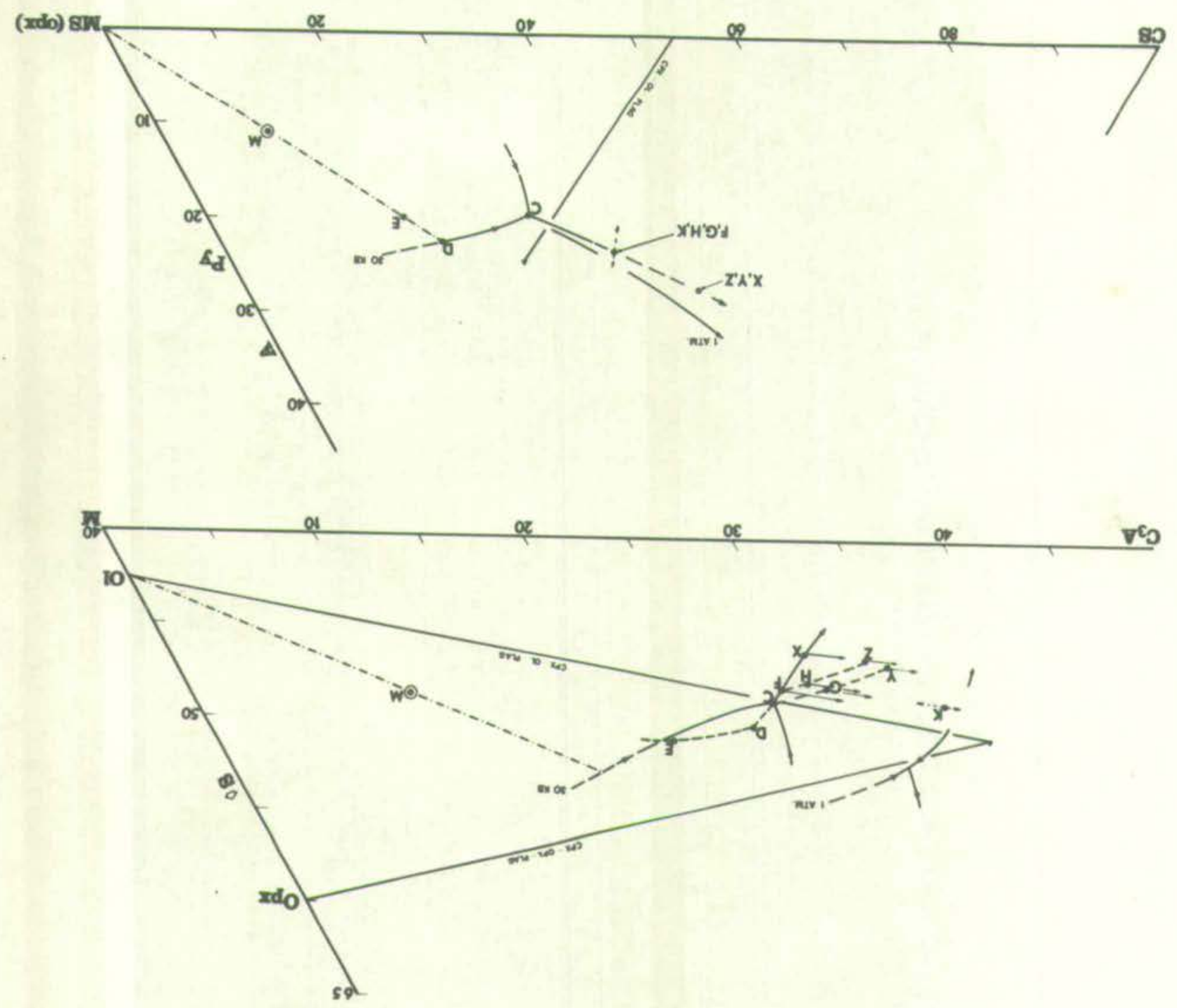


\section{A CKN OWLEDGEMENT S}

During my period of research at the Grant Institute of Geology I benefitted not only from the excellent facilities, but also from the stimulating and friendiy atmosphere to which all members of the Institute have contributed. I am grateful to Professor F.H. Stewart for permitting me to carry out my research here.

Dr. B.G.J. Upton suggested the study of Grande Comore, and provided continuous guidance and supervision during its progress. I extend to him my sinoere gratitude and appreciation.

I am especially grateful to Dr. B.G. Jamieson for his efforts In improving this thesis, both through many enlightening disoussions and by his oritiolsm of the manuseript.

I also wish to express my appreciation to the many people who helped in the following ways.

Messrs. G.R. Angell and M.J. Saunders gave detailed instructions In chemical analysis by X-ray fluorescence and classical techniques, respectively. The analytical programme also benefitted from discussions with Drs. N.B. Price, B.G. Jamieson and D.B. Clarke, and it would have been difflcult without the computer programmes witten by Dr. D.H. Doff and Mr. J.D. Appelton.

The electron microprobe analyses were obtained through the kindness of Dr. C.H. Fmeleus (Durham University), and the rare-earth determinations were generously provided by Mr. M.F.J. Flower (Manchester University). 
Computer programmes were written by Dr. R.F. Cheeney for C.I.P.W. norms, by Dr. M.J. O'Hara for C.M.A.S. projections, and by Dr. A.J.Parsley for discriminant function analysis.

Drs. K.G. Cox and M.J. O'Hara gave generously of their time in trying to improve my understanding of the theoretical aspects of igneous petrology, and Chapter 6 was particularly influenced by discussions with Dr. Cox.

Field assistance was provided by Mr. M.F.J. Flower, and M. and Mme. Claude Jacquot were especially helpful in the invest1gation of the Kartala caldera. Access to difficult areas was made possible by Land Rovers lent by Ministre Ahmed Dahalani, the Prefect of Grande Comore, by Mikidache Abdou 'Rahim, by M. Jean Malliet, Director of the Societe Developement Economique des Comores (SODEC), and by M. Plerre Andre Lambert, Technical Director of SODEC, at Moroni. M. Malllet also provided free access to the SODEC's aerlal photographs of Grande Comore.

My wife, Lynda, carried out much of the preliminary typing of the thesis, and was continuously encouraging during the research. Financial support for the field work was provided by grants from the Natural Bnvironment Research Councll to Dr. B.G.J. Upton and Dr. W.J. Wadsworth. The National Research Council of Canada awarded postgraduate scholarships for two years of the period of research.

I am extremely grateful to Mr. Colin Chaplin and his technical staff for thelr help throughout the study in the preparation of thin sections, polished seotions, and photographs. 


\section{BIBLIOGRAPHY}

Abbott, M.J., 1969. Petrology of the Nandewar voleano, N.S.W., Australia. Contr. Mineral. and Petrol. 20, 115-134.

Bailey, D.K., 1964. Crustal warping - a possible tectonio control of alkaline magmatism. J. geophys. Res. 69, 1103-1111.

Baker, I., 1969. Petrology of the volcanic rocks of Salnt Helena Island, South Atlant1c. Bull. geol. Soc. Am. 80, 1283-1310

Baker, P.E., Gass, I.G., Harr1s, P.G. and LeMa1tre, R.W., 1964. The volcanological report of the Royal Society expedition to Tristan da Cunha, 1962. Phil. Trans. R. Soc., A 256, 439-578.

Birch, F., 1960. The velocity of compressional waves in rocks to 10 Kilobars. J. Reophys. Res. 65, 1083-1102.

Bowen, N.L. and Schalrer, J.F., 1935. The system MgO-FeO-SiO 2 Am. J. So1. 229, 151-217.

Boyd, F.R., England, J.L. and Davis, B.T.C., 1964. Effects of pressure on the melting and polymorphism of enstatite, $\mathrm{MgSiO}_{3}$. J. geophys. Res. $69,2101-2109$.

Brown, G.M., 1967. Mineralogy of basaltic rooks, pp. 103-162, in Basalts: the Poldervaart Treatise on rocks of basaltic composition, eds, Hess, H.H., and Poldervaart, A., N.Y.: Intersoience.

Bryan, W.B., 1967. Geology and petrology of Clarion Island, Mexico. Bull. geol. Soc. Am. 78, 1461-1476.

Carswell, D.A. and Dawson, J.B., 1970. Gamet peridotite xenoliths in South African kimberlite pipes and their petrogenesis. Contr. Mineral. and Petrol. 25, 163-184.

Chayes, F., 1964. Variance-covariance relations in some published Harker diagrams of volcanic suites. J. Petrology 5 , $219-237$.

Clark, S.P. and Ringwood, A.E., 1964. Dens1ty distribution and constitution of the mantle. Rev. Geophys. 2, 35-88.

Clarke, D.B., 1970. Tertiary basalts of Baffin Bay: possible primary magma from the mantle. Contr. Mineral. and Petrol. 25, 203-224. 
Coombs, D.S., 1963. Trends and affinities of basaltic magmas and pyroxenes as illustrated on the diopside-olivine-silica diagram. Spec. Pap. miner. Soc. Am. 1, 227-250.

Coombs, D.S. and Wilkinson, J.F.G. 1969. Lineages and fractionation trends in undersaturated volcanio rooks from the East Otago Volcanic Province (New Zealand) and related rooks. J. Petrolog: 10, 440-501.

Davidson, C.F., 1967. The so-called "cognate xenoliths" of kimberlite, pp. 342-346 in Ultramafic and Related Rocks, ed. Wyllie, P.J., N.Y.: John Wiley and Sons, Inc.

Davis, B.T.C. and Schairer, J.F., 1965. Melting relations in the join diopside-fosterite-pyrope at $40 \mathrm{~K} 11$ obars and at one atmosphere. Yo. Carnegie Instn Wash. 64, 123-126.

De Saint Ours, J., 1960. Etudes Geologiques dans L'extreme Nord de Madagascar et L'Archipel des Comores. Republique Malagache, Ministere de L'Economio Nationale, Service Geologique, Tananarive.

Dixey, F., 1956. The East African Rift System. Col. Geol. Min. Resources Supp. Ser. 1.

Esson, J., Flower, M.F.J., Strong, D.F., Upton, B.G.J. and Wadsworth, W.J., Geology of the Comores Archipelago. Geol. Mag. in press.

Fisher, R.L., Johnson, G.L. and Heezen, B.C., 1967. Mascarene Plateau, Westerm Indian Ocean. Bull. geol. Soc. Am. 78, 1247-1266.

Fisher, R.L., Engel, C.G. and Hilde, T.W.C., 1968. Basalts dredged from the Amirante Ridge, Western Indian Ocean. Deep Ser Res. 15, 521-534.

Fiske, R.S. and Kinoshita, W.T., 1969. Inflation of Kilauea Volcano prior to its 1967-1968 eruption. Solence, N.Y. 165, $341-349$.

Flower, M.F.J. and Strong, D.F., 1969. The signifloance of sandstone inclusions in lavas of the Comores Archipelago. Earth planet. So1. Lett. 7, 47-50.

Francis, T.J.G., Davies, D. and Hill, M.N., 1966. Crustal structure between Kenya and the Seychelles. Phil. Trans. R. Soc., A $259,240-261$.

Gardiner, J.S., 1936. The reefs of the western Indian Ocean. I. Chagos Archipelago, II. The Mascarene region. Linn. Soc. Lond. Trans. (Zoology) 19, 393-436. 
Gast, P.W., 1965. Terrestrial ratio of potassium to rubidium and the composition of the earth's mantie. Sclence, N.Y. $147,858-860$.

Gast, P.W., 1968. Trace element fractionation and the origin of tholeiltic and alkaline magma types. Geochim. cosmochim. Acta 32, 1057-1086.

Goulden, C.H., 1952. Methods of Stat1st1cal Analysis. N.Y., Lond.: John Wiley and Sons, Inc.

Green, D.H., 1969. The origin of basaltic and nephelenitic magmas in the earth's mantle. Teatonophys. 7, 409-422.

Green, D.H. and Ringwood, A.E., 1967. The genesis of baseltic magmas. Contr. Mineral. and Petrol. 15, 103-190.

Griffen, W.L. and Murthy, V.R., 1969. Distribution of K, Rb, Sr and $\mathrm{Ba}$ in some minerals relevant to basalt genesis. Geochim. cosmochim. Acta 33, 1389-1414.

Gullcher, A., 1965. Coral reefs and lagoons of Mayotte Island, Comoro Archipelago, Indian Ocean, and of New Caledonia, Pacific Ocean, pp. 21-45 in Submarine Geology and Geophysics. eds. Whittard, W.F. and Bradshaw, R. Lond.: Butterworths.

Harris, P.G., 1957. Zone-refining and the origin of potassic basalts. Geochim. cosmochim. Acta 12, 195-208.

Harris, P.G., 1967. Segregation processes in the upper mantle, pp. 305-317 in Mantles of the Earth and Terrestrial Planets, ed. Runcorn, S.K., New York: Interscience.

Harris, P.G. and Middlemost, E.A.K., 1970. The evolution of kimberlites. Lithos 3, 77-88.

Harris, P.G., Reay, A. and White, I.G., 1967. Chemical composition of the upper mantle. J. geophys. Res. 72, 6359-6369.

Haskin, L. and Gehl, M.A., 1962. The rare-earth distribution in sediments. J. geophys. Res. $67,2537-2541$.

Holmes, A., 1965. Principles of Physical Geology. London and Edinburgh: Thomas Nelson, Ltd.

Hope, K., 1968. Methods of Multivariate Analysis. Lond.: Univ. Lond. Press.

Hurley, P.M., 1957. Test on the possible chondritic composition of the earth's mantle and its abundance of uranium, thorium, and potassium. Bull. geol. Soc. Am. 68, 379-382. 
Hurley, P.M., 1968a. Absolute abundance and distribution of Rb, $\mathrm{K}$ and $\mathrm{Sr}$ in the Earth. Geochim. cosmoohim. Acta 32, $273-283$.

Hurley, P.M., 1968b. Correction to: Absolute abundance and distribution of $\mathrm{Rb}, \mathrm{K}$ and $\mathrm{Sr}$ in the Earth. Geochim. cosmoahim. Aota 32, 1025-1030.

Ito, K. and Kennedy, G.G., 1967. Melting and phase relations in a natural poridotite to 40 kilobars. Am. J. Soi. 265 , 519-538.

Jagger, T.A., 1947. Oxigin and Development of Craters. Geol. Soc. Am. Mern. 21.

Jamieson,B.G., 1966. Evolution of basalt magma at elevated pressures. Nature, Lond. 219, 1240-1241.

Jamieson,B.G., 1969. Natural rock projection into a pseudo-quaternary system, pp. 152-155 in Progress in Experimental Petrology, N.E.R.C. Ist Report, Manchester:Ednburgh.

Jamieson, B.G., 1970. Phase relations in some tholeiltic lavas illustrated by the system $\mathrm{R}_{2} \mathrm{O}_{3}-\mathrm{XO}-\mathrm{YO}_{2} \mathrm{ZO}_{2}$. Mineralog. Mag. in press.

Johannsen, A., 1938. A Descriptive Petrography of the Igneous Rocks, Vol. IV. Chicago: Univ. Chicago Press.

King, B.C. and Sutherland, D.L., 1960. Alkaline rocks of Eastern and Southern Afrioa. So1. Prog. 48, pt. I, 298-321; pt. II, 504-523; pt. III, 709-720.

Krumbein, W.0. and Grayb111, F.A., 1965. An Introduction to Statistical Models in Geology. N.Y.: MoGraw-Hill.

Kushiro, I., 1968. Compositions of magmas formed by partial zone melting of the earth's upper mantle. J. geophys. Res. $73,619-634$.

Kushiro, I., Yashuhiko, S. and Akimoto, S., 1968. Melting of a peridotite nodule at high pressures and high water pressures. J. geophys. Res. 73, 6023-6029.

Kutolin, V.A., 1970. Ultrabasic nodules in basalts and the upper mantle composition. Earth planet. Sc1. Lett. 7, 330-332.

Lacrolx, A., 1922. La Constitution Iithologique de I'Archipel des Comores. Proc. 23rd Internat. Geol. Congr., Brussels. 2, 947-979.

Lacrolx, A., 1938. Le volcan actif de L'Ile de la Rounion et celui de La Grande Comore. Paris: Gauthier-Villars. 
LeMaltre, R.W., 1962. Petrology of the volcanic rocks, Gough Island, South Atlant 1c. Bull. ge0l. Soc. Am. 73, 1309-1340.

Lovering, J.F., 1958. The nature of the Mohorovicle discontinulty. Trans. Am. geophys. Un. 39, 947-955.

Luth, W.C. and Tuttle, O.F., 1969. The hydrous vapour phase in equilibrium with granite and granite magmas, pp. 513-548 in Igneous and Metamorphic Geology, eds. Larsen, L., Manson, V. and Prinz, M. Geol. Soc. Am. Mem. 115.

Maodonald, G.A., 1949. Hawa1ian petrographic province. Bull. geol. Soc. Am. 60, 1541-1595.

Macdonald, G.A., 1967. Forms and structures of extrusive basaltio rocks, pp. 1-61 in Basalts: the Poldervaart treatise on rooks of basaltio composition, eds. Hess, H.H. and Poldervaart, A., N.Y.: Intersclence.

Macdonald, G.A., 1968a. Composition and or Igin of Hawalian lavas, pp. 477-522 in studies in Voloanology, eds. Coats, R.R., Hay, R.L. and Anderson, C.A. Geol. Soc. Am. Mem. 116.

Macdonald, G.A., 1968b. A contribution to the petrology of Tutuila, American Samoa. Geol. Rdsch. 57, 821-837.

Macdonald, G.A. and Katsura, T., 1964. Chemioal composition of Hawallan lavas. J. Petrology 5, 82-133.

Macdonald, G.J.F., 1959. Chondrites and the chemical composition of the Earth, pp. 476-494 in Researches in Geochemistry, ed. P.H. Abelson. N.Y.: John Wiley and Sons.

Macgregor, A.G., 1948. Problems of Carboniferous-Permian volcanicity 1 Sootland. Q. J1. geol. Soc. Lond. 104, 133-153.

Manson, V., 1967. Geoohemistry of basaltic rooks: major elements, pp. 215-269 in Basalts: the Poldervarert treatise on rocks of basaltic composition, eds. Hess, H.H. and Poldervaart, A., New York: Interscience.

Marshall, P., 1929. The volcanio rocks of the Cook Islands. 4th Paclfic Sci. Congr., Proc. 2B. 901-903.

MoBimey, A.R. and Aoki, K., 1968. Petrology of the Island of Tahit1, pp. 523-556 in Studies in Volcanology, eds. Coats, R.R., Hay, R.L. and Anderson, C.A. Geol. Soc. Am. Mem. 116. 
Murata, K.J. and Richter, D.H., 1966a. The settling of ollvine in Kilauean magma as shown by the lavas of the 1959 eruption. Am. J. So1. 264, 194-203.

Murata, K.J. and Rlchter, D.H., 1966b. Chemistry of the lavas of the 1959-60 eruption of Kilauea Volcano, Hawail. Prof. Pap. U.S. geol. Surv. 537-A.

Murray, R.J., 1954. The clinopyroxenes of the Garbh Eilean sill, Shiant Isles. Geol. Mag. 91, 17-31.

Morey, G.W. and Hesselgesser, J.M., 1951. The solubility of some minerals in superheated steam at high pressure. Econ. Geol. 46, 821-835.

Nixon, P.H., Von Knorring, O. and Rooke, J.M., 1963. Kimberlites and associated inclusions of Basutoland: A mineralogioal and geochemical study. Am. Miner. 48, 1090-1132.

O'Hara, M.J., 1965. Primary magmas and the origin of basalts. Soott. J. Gool. 1, 19-40.

0'Hara, M.J., 1967. Crystal-1iquid equilibria and the orlgins of ultramafic nodules in basic igneous rooks, pp. $346-349$ In UItramafic and Related Rocks, ed. Wyllie, P.J., N.Y.: John Wiley and Sons, Inc.

O'Hara, M.J., 1968. The bearing of phase equilibria studies in synthetic and natural systems on the origin and evolution of basic and ultrabasic rooks. Earth-Sc1. Rev. 4, 69-133.

0'Hars, M.J., 1970. Upper mantle composition inferred from laboratory experiments and observation of voleanic products. Phys. Earth Planet. Interiors 3, 236-245.

O'Hara, M.J. and Yoder, H.S., Jr., 1967. Formation and fractionation of basic magmas at high pressures. Scott. J. Geol. 3, 67-117.

Pepper, J.F. and Everhart, G.M., 1963. The Indian Ocean, the geology of its bordering lands and the configuration of Its floor. U.S. geol. Surv. Misoellaneous Goologic Investigations, Map $1-380$ and accompanying text.

Presnall, D.C., 1969. The geometrical analysis of partial fusion. Am. J. Sci. 267, 1178-1194.

Press, F., 1969. The Suboceanic Mantle. Solence, N.Y. 165, 174-176. 
Prinz, M., 1967. Geochemistry of basaltic rocks: trace elements, pp. 271-323 in Basalts: the Poldervaart treatise on rocks of basaltic composition, eds. Hess, H.H. and Poldervaart, A., New York: Intersoience.

Prosper1, F., 1957. Venished Continent: An Italian Expedition to the Comores Islands, trans. by D. Moore. Lond.: Hutchinsons.

Reay, A. and Harris, P.G., 1964. The partial fusion of peridotite. Bu11. Volc. $27,115-127$.

Robson, G.R. and Barr, K.G., 1964. The effect of stress on faulting and minor intrusions in the vicinity of a magma body. Bull. volc. 27, 315-330.

Saggerson, E.P. and Williams, L.A.J., 1964. Ngurumanite from southern Kenya and its bearing on the origin of rocks in the northern Tanganyika alkaline district. J. Petrology 5 , 40-81.

Sohilling, J.G. and Winchester, J.W., 1967. Rare-earth fractionation and magmatio processes, pp. 267-283 in Mantles of the Barth and Terrestrial Planets, ed. Runeorn, S.K., New York: Interscience.

Schilling, J.G. and Winchester, J.W., 1969. Rare-earth contribution to the origin of Hawalian Lavas. Contr. Mineral. and Petrol. $23,27-37$.

Sohmitt, R.A., Smith, R.H. and Olehy, D.A., 1964: Rare-earth, yttrium and scandium meteoritic and terrestrial matter II. Geochim. cosmochim. Acta 28, 67-86.

Shaw, D.M., 1968. A review of $\mathrm{K} / \mathrm{Rb}$ fractionation trends by covariance analysis. Geochim. cosmochim. Acta 32, 573-602.

Simmons, G., 1964. Velocity of shear waves in rocks to $10 \mathrm{kllobars.}$ J. geophys. Res. 69, 1123-1130.

Smith, R.E., 1967. Segregation vesicles in basaltic lava. Am. J. Sci. $265,696-713$.

Spencer, A.B., 1969. Alkalic igneous rocks of the Balcones Province, Texas. J. Petrology 10, 272-306.

Stark, J.T. and Hay, R.L., 1963. Geology and petrography of volcanic rocks of the Truk Islands, East Caroline Islands. Prof. Pap. U.S. geol. Surv. 409. 
Steams, H.T. and Vaksvik, K.N., 1935. Geology and ground-water resources of the island of Oahu, Hawali. U.S. geol. Surv. Bull. 1 .

Stiee, G.D., 1968. Petrography of the Menu'a Island, Samoa. Contr. Mineral. and Petrol. 19, 343-357.

Strong, D.F. and Jacquot, C., 1969. The Kartala caldera, Grande Comore, p. 109 in Symposium on Volcanoes and their Roots, vol. of abstr., Oxford, Sept. 1969. Int. Ass. Volc. Chem. Earth's Interior. (submitted to Bull. volc.)

Talwan1, Manik., 1962. Gravity measurements in the Indian Ocean. Bul1. geol. Soc. Am. 73, 1171-1182.

Turekian, K.K. and Clark, S.P.Jr., 1969. Inhomogeneous accumulation of the earth from the primitive solar nebula. Earth planet. Soi. Lett. $6,346-348$.

Turner, F.J. and Verhoogen, J., 1960. Igneous and metamorphic petrologi. New York: MoGraw-H111.

Upton,B.G.J. (ed.), 1969. Carboniferous volcanic rocks of the Midland Vailey of scotland, fleld excursion guide. Symposium on Volcanoes and their Roots, Int. Ass. Volc. Chem. Earth's Interior.

Upton, B.G.J. and Wadsworth, W.J. 1966. The basalts of Reunion Island, Indian Ocean. Bull. Volc. 29, 7-24.

Upt on, B.G.J., Wadsworth, W.J. and Newman, T.C., 1967. The petrology of Rodriguez Island, Indian Ocean. Bull. geol. Soc. Am. $78,1495-1506$.

Urey, H.C., 1952. The Planets, their Origin and Development. Yale Un1v. Pross.

Van Padang, M. Neumann, ed., 1963. The volcanoes of the western part of the Indian Ocean, pp. 32-39 in Catalogue of the Active Volcanoes of the World, Including Solfatara flelds, part XVI, Arabia and the Indian Ocean.

Varne, R., 1962. The petrology of Moroto Mountain, Eastern Uganda, and the origin of nephelinites. J. Petrology 9, 169-190.

Veeh, H.H., 1966. Ages of Pleistocene high sea level staid. J. geophys. Res. 71, 3379-3386.

Vienne, E., 1900. Colonies et Pays de Protectorates Mayotte et Comores. Paris: Exposition Universelle de 1900.

Vinogradov, A.P., 1962. Average contents of chemical elements in the principal types of igneous rocks of the Barth's crust. Geochemistry (trans. of Geokhimiya) 1962, 641-664. 
Voeltzkow, A., 1906. Die Comoren, pp. 606-630 in Zeits. der Ges. für Erdkunde zu Berlin.

Walker, F. and Nicolaysen, L.0., 1953. The petrology of Maunitius. Col. Geol. Miner. Res. 4, 3-43.

Wilkinson, J.F.G., 1956. Clinopyroxenes of alkali olivine-basalt magma. Am. Miner. 41, 724-743.

Williams, H., 1933. Geology of Tahit1, Moorea, and Ma10. B.P. Bishop Mus. Bull. 105.

Williams, L.A.J., 1969. Volcanic associations in the Gregory Rift Valioy, East Africa. Nature, Lond. 224, 61-64.

Wood, C.P., 1968. A geochemical study of East African alkaline lavas and its relevance to the petrogenesis of nephelinites Univ. Leeds Ph. D. thesis (unpubi.).

Wood, C.P., 1969. Geochemistry of volcanic rooks of the cook Islands, pp. 38-39 in U.K. Information sheet on the Upper Mantie, 4.

Yag1, K., 1960. Petrochem1stry of the alkalic rooks of Ponape Island, western Pacific Ocean. Rop. 2lst Intemat. geol. Congr. (Norden) pt. 13, 108-122.

Yoder, H.S.,Jr. and Tilley, C.E., 1962. The origin of basalt magmas: an experimental study of natural and synthetic systems. J. Petrology 3, 342-532. 


\section{APPENDIX A}

\section{Analytical and Determinative Methods}

A.1. Preparation of rock powders

A.2. X-ray fluorescence analysis

A. 3. Wet chemical methods

A.4. Electron microprobe analysis

A.5. Optical determinations

A.6. Modal analysis

A.7. Olivine $\mathrm{X}$-ray diffraction method. 


\section{A.1. Preparation of rock powders}

Rock powders were prepared using the methods currently in use at the Grant Institute of Geology, and these methods are summarized as a flow chart in Figure A-1. For most hand specimens three hundred to a thousand grams of one-quarter inch chips were prepared, depending upon the grain size and percentage of phenocrysts in the rook, as outlined by Wager and Brown (1960, Table 1, p. 6). For some glassy or very fine-grained aphyric rocks less than one hundred grams were prepared, since differences within the hand specimen would be insignificant relative to those within the whole flow.

Qualitative tests showed that the "Columboy" Tema disk mill produces unacceptable $\underline{\mathrm{N} 1}$ and $\underline{\mathrm{Cr}}$ contamination (Table A-1), so specimens analysed for these elements were ground in the agate or tungsten carbide ball mills. All powders from the ball mills were sieved through 100 mesh B.S. nylon screen, and the few grains of material commonly present after sleving were ground with an agate mortar and pestle. Initial checks showed that the Tema disk mill produced -100 mesh powders (grinding time dependent upon the amount of sample present), and sleving of these powders was therefore discontinued. No equipment contamination was found for other elements determined in this study (Table A-1). 


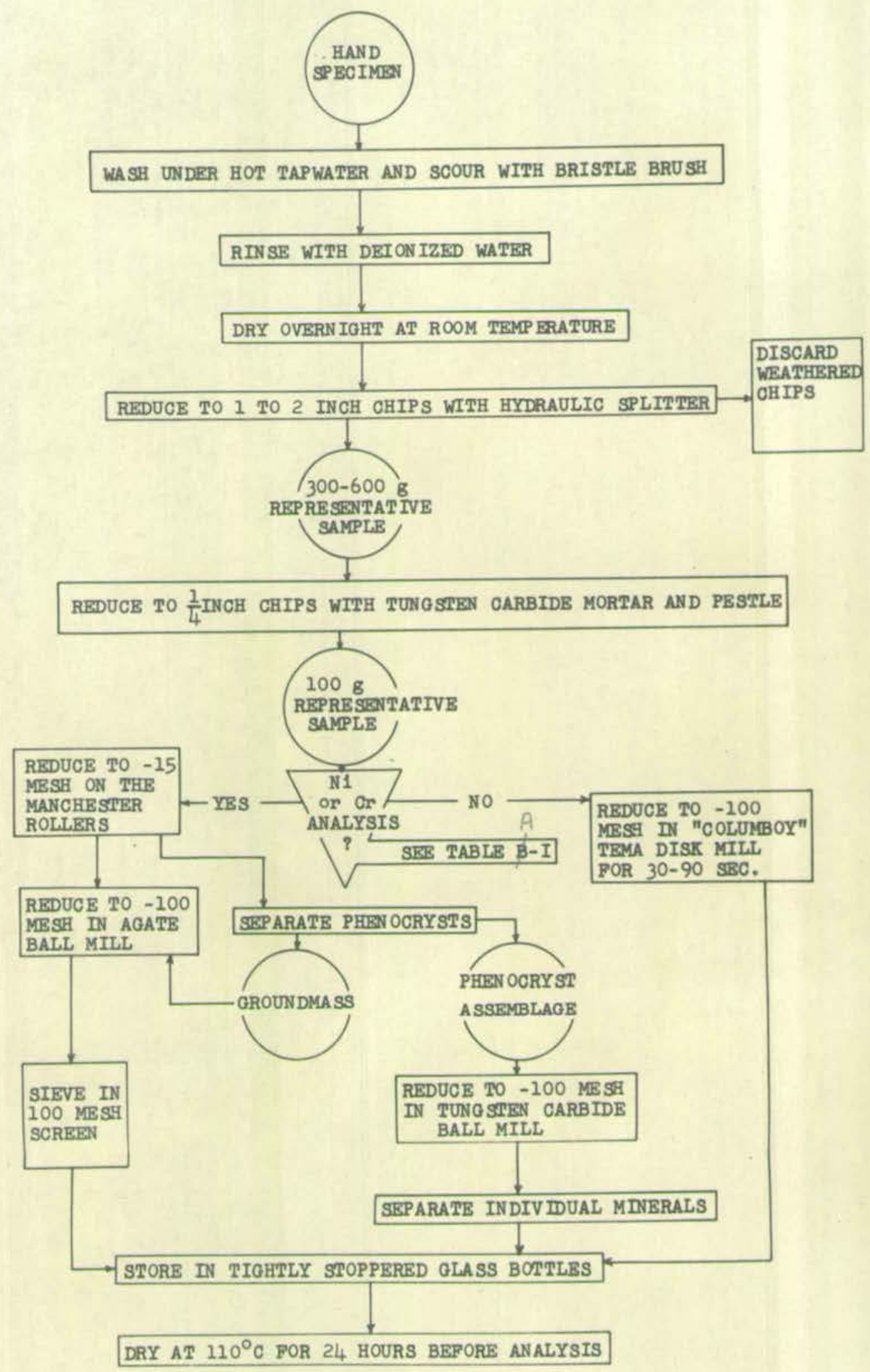


Table A-1

Qualitative tests for contamination from grinding equipment

\begin{tabular}{|c|c|c|c|c|c|c|c|c|c|c|c|c|}
\hline & ppm & $\mathrm{Ba}$ & & $r$ & Sr & $\mathrm{Rb}$ & $\mathrm{zr}$ & & $\mathrm{Cu}$ & $\mathrm{N} 1$ & & Cr \\
\hline \multirow{2}{*}{1} & A & 390 & & & 475 & 20 & 9 & & 105 & 180 & & 260 \\
\hline & $\mathrm{T}$ & 450 & & & 500 & 26 & 106 & & 89 & 1760 & & 298 \\
\hline \multirow{2}{*}{4} & A & 520 & & & 510 & 24 & 100 & & 90 & 170 & & 100 \\
\hline & $\mathrm{T}$ & 485 & & & 524 & 32 & 116 & & 85 & 1460 & & 277 \\
\hline \multirow{2}{*}{6} & A & 470 & & & 425 & 20 & 107 & & 101 & 100 & & 40 \\
\hline & $\mathrm{T}$ & 470 & & & 474 & 25 & 111 & & 94 & 1690 & & 271 \\
\hline \multirow{2}{*}{23} & A & 500 & & & 460 & 24 & 112 & & 101 & 178 & & 200 \\
\hline & $T$ & 390 & & & 480 & 26 & 112 & & 95 & 1960 & & 620 \\
\hline \multirow{2}{*}{26} & A & 440 & & & 473 & 24 & 88 & & 83 & 200 & & 130 \\
\hline & $T$ & 400 & & & 492 & 26 & 102 & & 99 & 1660 & & 420 \\
\hline \multirow{2}{*}{31} & A & 218 & & & 289 & 13 & 100 & & 103 & 480 & & 775 \\
\hline & $T$ & 250 & & & 305 & 13 & 9. & 3 & 90 & 770 & & 800 \\
\hline \multicolumn{2}{|c|}{ wt. \%. } & $\mathrm{SiO}_{2}$ & $\mathrm{THO}_{2}$ & $\mathrm{Al}_{2} \mathrm{O}_{3}$ & $\mathrm{Fe}_{2} \mathrm{O}_{3}$ & $\mathrm{FeO}$ & Mno & $\mathrm{MgO}$ & $\mathrm{CaO}$ & $\mathrm{Na}_{2} \mathrm{O}$ & $\mathrm{K}_{2} \mathrm{O}$ & $P_{2} O_{5}$ \\
\hline \multirow{2}{*}{31} & A & $46 \cdot 65$ & $1 \cdot 58$ & $9 \cdot 70$ & 2.53 & $8 \cdot 86$ & $\cdot 19$ & $15 \cdot 60$ & 11.95 & 1.98 & .61 & $\cdot 22$ \\
\hline & $\mathrm{T}$ & $46 \cdot 76$ & 1.58 & $9 \cdot 76$ & $2 \cdot 46$ & 8.87 & $\cdot 19$ & $15 \cdot 98$ & $11 \cdot 00$ & 1.93 & .61 & $\cdot 25$ \\
\hline
\end{tabular}

A : "CUT ROCK" Jaw-splitter $\rightarrow$ Manchester rollers $\rightarrow$ agate ball mill. T: "$$
\text { " }
$$$$
\rightarrow \text { Tema disk mill. }
$$ 
For the separation of phenocrysts, rocks were crushed to the phenocryst size (generally between 48 and 15 mesh), and run through a magnetic separator at very low current strength. This permits clean separation of the phenocrysts and groundmass, as all magnetite is concentrated in the groundmass and renders it highly magnetic. After separation, the phenocrysts were ground to -100 mesh in a tungsten carbide ball mill, and individual minerals were then separated on the magnetic separator. However, because of overlap in magnetic properties of olivine and some clinopyroxene fractions, clean olivine could not be obtained by this method. These clinopyroxene + olivine fractions were thus discarded and the olivine phenocrysts were hand-picked from the bulk powders. Because of this it must be noted that the clinopyroxene analyses do not represent the complete phenocrysts, but only the least magnetic part, about $90 \%$ of the total. 
A.2. X-ray fluorescence analysis

The analyses for all trace elements and all major elements except $\underline{\mathrm{FeO}}, \underline{\mathrm{Na}_{2}} \mathrm{O}$ and $\underline{H}_{2} \mathrm{O}$ were carried out by $\mathrm{X}$-ray fluorescence spectroscopy, using Phillips PW 1212 twenty-four channel automatio or PW 1540 single channel spectrometers with standard instrument settings (e.g. see Norrish and Futton, 1968). Trace elements were determined directly on the rock powders by calculating the ratios of peak to background and reading concentrations off linear calibration curves. The calibration curves were visually estimated as the best fit straight line through points obtained by plotting concentrations against ratios of peak to background for at least ten international standard rocks powders. The ratios of peak to background were calculated from counts corrected for instrument drift by means of a short computer program modified by the writer from a similar program written by D.H. Doff. The precision of this method has been determined on a single rock powder of the basalt No.I (Tsble C-I) and th results are shown in Table $\mathrm{A}-2$.

Major elements were determined on disks of fused rock powders prepared as shown in Figure A-2, after the method of Rose, et al. (1963). This method of preparation removes matrix effects so as to produce linear calibration curves, and renders unnecessary any mathematical corrections for matrix or mass absorption effects (cf. Holland, 1966, or Norrish and Hutton, 1969). The chemical results were calculated by means of a computer program (modified by J.D. Appelton after D.H. Doff) which corrects for instrument drift, 
Table A-2

Preciston of X-ray Fluorescence Analyses

\begin{tabular}{|c|c|c|c|c|c|}
\hline $\mathrm{p} \cdot \mathrm{p} \cdot \mathrm{m}$. & $\bar{x}$ & $\mathbf{R}$ & s & c & $\mathrm{n}$ \\
\hline $\mathrm{Rb}$ & 29 & 18 & 6 & $20 \%$ & 6 \\
\hline $\mathrm{Cu}$ & 102 & 26 & 8 & $8 \%$ & 6 \\
\hline $\mathrm{Sr}$ & 512 & 22 & 8 & $2 \%$ & 6 \\
\hline $\mathrm{Ba}$ & 381 & 65 & 23 & $6 \%$ & 6 \\
\hline $\mathrm{Zn}$ & 93 & 15 & 5 & $5 \%$ & 6 \\
\hline $\mathrm{Zr}$ & 201 & 28 & 9 & $5 \%$ & 6 \\
\hline $\mathrm{Cr}$ & 337 & 40 & 37 & $11 \%$ & 3 \\
\hline N1 & 212 & 27 & 14 & $7 \%$ & 4 \\
\hline wt. \% & & & & & \\
\hline $\mathrm{SiO}_{2}$ & $47 \cdot 05$ & 0.33 & 0.13 & $0.27 \%$ & 7 \\
\hline $\mathrm{Al}_{2} \mathrm{O}_{3}$ & $13 \cdot 23$ & 0.25 & 0.08 & $0.60 \%$ & 7 \\
\hline $\mathrm{Fe}_{2} \mathrm{O}_{3}$ & $12 \cdot 70$ & 0.46 & 0.15 & $1 \cdot 18 \%$ & 7 \\
\hline $\mathrm{MgO}$ & $9 \cdot 21$ & 0.21 & 0.10 & $1.09 \%$ & 7 \\
\hline $\mathrm{CaO}$ & $11 \cdot 36$ & 0.20 & 0.06 & $0.53 \%$ & 7 \\
\hline $\mathrm{K}_{2} \mathrm{O}$ & $1 \cdot 25$ & 0.01 & 0.01 & $0.76 \%$ & 7 \\
\hline $\mathrm{P}_{2} \mathrm{O}_{5}$ & 0.43 & 0.05 & 0.02 & $4.65 \%$ & 7 \\
\hline $\mathrm{TiO}_{2}$ & $2 \cdot 38$ & 0.09 & 0.03 & $1.14 \%$ & 7 \\
\hline
\end{tabular}

$\bar{x} \quad$ Mean concentration

R Range $=$ maximum-minimum concentration obtained

$s$ standard deviation from the mean

c coeffloient of variation

$n$ number of determinations

$\mathrm{Fe}_{2} \mathrm{O}_{3}=$ total iron as $\mathrm{Fe}_{2} \mathrm{O}_{3}$ 


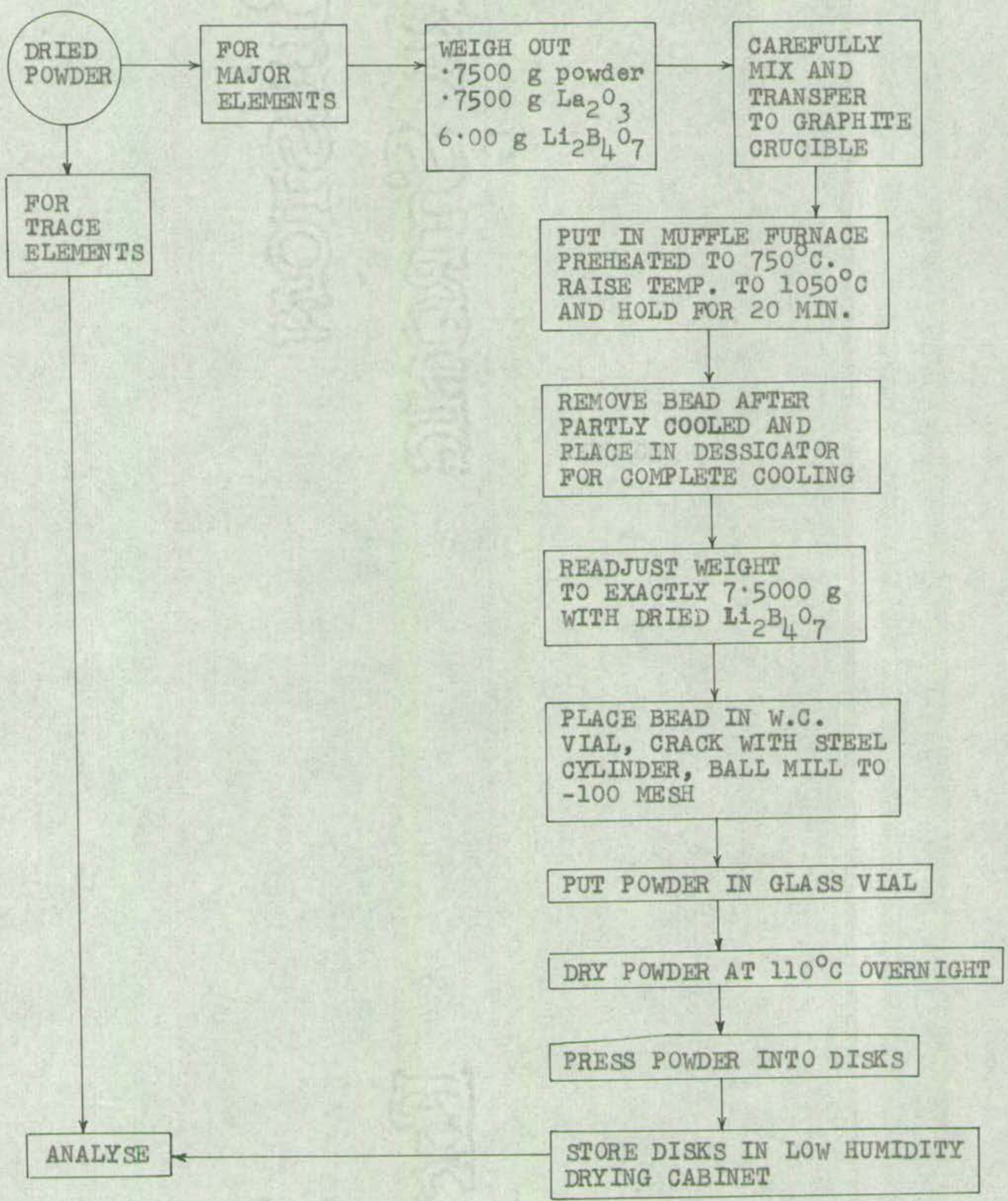


ealculates a regression line, and calculates the data from this regression. Along with the data the programme also prints out comelation coefficients for the regression line of each element, and reclaculates the conoentration of each element in the standards used. This permits a rapid evaluation of the quality of each set of determinations, and the data for one such set of determinations are reproduced in Pable A-3. The precision for each element has been determined on No.1, as shown in Table A-2. These data were obtained for separate fusion powders, and thus incorporate precision of the preparation technique as well as Instrument precision. The acouracy of the method was determined from the three international rock standards DIS-1 (dunite), NBS-91 (silica brick), and BGR-1 (basalt), and the results are presented in Table $\mathrm{A}-4$. 
Table A - 3

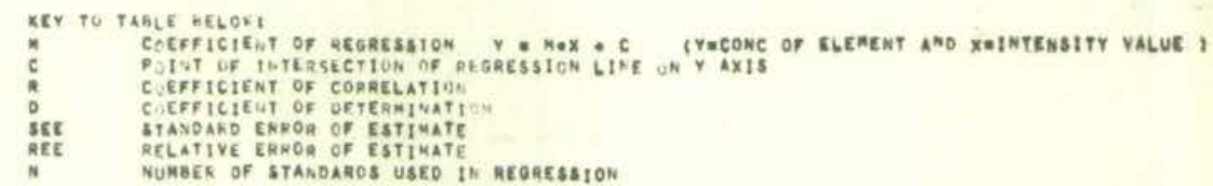

\begin{tabular}{|c|c|c|c|c|c|c|c|c|}
\hline & $C_{A}$ & k & FE & 11 & 51 & A6 & wo & e. \\
\hline$P C C-1$ & $\begin{array}{l}95500 \\
0.481 \\
0.420\end{array}$ & $\begin{array}{r}3750 \\
0.000 \\
0.010\end{array}$ & $\begin{array}{l}00754 \\
0.663 \\
50160\end{array}$ & $\begin{array}{l}19042 \\
0.012 \\
0.010\end{array}$ & $\begin{array}{l}157845 \\
42.146 \\
41.900\end{array}$ & $\begin{array}{r}2563 \\
0.777 \\
0.760\end{array}$ & $\begin{array}{r}23731 \\
43.597 \\
43.320\end{array}$ & $\begin{array}{r}0.001 \\
0.0010 \\
\end{array}$ \\
\hline$D x-24$ & $\begin{array}{r}916495 \\
9.930 \\
10.200\end{array}$ & $\begin{array}{r}5607 \\
0.029 \\
-1.000\end{array}$ & $\begin{array}{l}114096 \\
11.310 \\
11.790\end{array}$ & $\begin{array}{r}127567 \\
0.001 \\
0.900\end{array}$ & $\begin{array}{l}173560 \\
45.094 \\
45.980\end{array}$ & $\begin{array}{r}20090 \\
11.378 \\
11.450\end{array}$ & $\begin{array}{l}12709 \\
16.424 \\
16.010\end{array}$ & $\begin{array}{r}\frac{236}{0.110} \\
-1.000\end{array}$ \\
\hline$G S P-1$ & $\begin{array}{r}221409 \\
1.030 \\
2.000\end{array}$ & $\begin{array}{r}362653 \\
5.462 \\
50500\end{array}$ & $\begin{array}{l}46703 \\
4.421 \\
4.260\end{array}$ & $\begin{array}{r}100376 \\
0.669 \\
0.060\end{array}$ & $\begin{array}{l}200285 \\
66.748, \\
67.260\end{array}$ & $\begin{array}{r}39062 \\
19.242 \\
10.200\end{array}$ & $\begin{array}{l}1006 \\
1.102 \\
0.050\end{array}$ & $\frac{030}{0.253}$ \\
\hline$M G$ & $\begin{array}{l}90771 \\
0.320 \\
0.560\end{array}$ & $\begin{array}{r}254176 \\
2.811 \\
-1.000\end{array}$ & $\begin{array}{l}19106 \\
1.643 \\
1.600\end{array}$ & $\begin{array}{l}32000 \\
0.110 \\
0.110\end{array}$ & $\begin{array}{l}319718 \\
80.756 \\
80.970\end{array}$ & $\begin{array}{r}26901 \\
10.096 \\
10.020\end{array}$ & $\begin{array}{c}209 \\
0.184 \\
0.120\end{array}$ & $\begin{array}{c}\frac{.80}{2.000} \\
0.010\end{array}$ \\
\hline NBS -76 & $\begin{array}{r}27573 \\
0.000 \\
=1.000\end{array}$ & $\begin{array}{r}103561 \\
1.510 \\
1.540\end{array}$ & $\begin{array}{l}23190 \\
2.047 \\
2.390\end{array}$ & $\begin{array}{r}200551 \\
2.221 \\
2.210\end{array}$ & $\begin{array}{l}203077 \\
93.149 \\
-1,000\end{array}$ & $\begin{array}{l}101116 \\
30,090 \\
=1,000\end{array}$ & $\begin{array}{r}900 \\
0.361 \\
-1.000\end{array}$ & $\begin{array}{l}0.035 \\
0.030 \\
0.070\end{array}$ \\
\hline NBS-77 & $\begin{array}{r}27556 \\
0.000 \\
=1.000\end{array}$ & $\begin{array}{r}138140 \\
2.045 \\
2.110\end{array}$ & $\begin{array}{l}11649 \\
0.809 \\
0.900\end{array}$ & $\begin{array}{r}381959 \\
20066 \\
=1.000\end{array}$ & $\begin{array}{l}115475 \\
32.040 \\
32.300\end{array}$ & $\begin{array}{l}159164 \\
61.910 \\
=1.000\end{array}$ & $\begin{array}{r}515 \\
0.477 \\
0.900\end{array}$ & $\begin{array}{r}1053 \\
0.401 \\
-1.000\end{array}$ \\
\hline$B C R-1$ & $\begin{array}{r}677900 \\
7.104 \\
6.920\end{array}$ & $\begin{array}{r}10526 \\
1.746 \\
1.690\end{array}$ & $\begin{array}{l}135369 \\
13.366 \\
13.2 \times 0\end{array}$ & $\begin{array}{r}292275 \\
2.235 \\
2.250\end{array}$ & $\begin{array}{l}211960 \\
54.958 \\
54.120\end{array}$ & $\begin{array}{r}35300 \\
13.900 \\
13.060\end{array}$ & $\begin{array}{r}2031 \\
3.910 \\
3.400\end{array}$ & $\begin{array}{r}970 \\
0.374 \\
0.390\end{array}$ \\
\hline$A G V-1$ & $\begin{array}{r}409024 \\
5.010 \\
40000\end{array}$ & $\begin{array}{r}105464 \\
2.917 \\
20.060\end{array}$ & $\begin{array}{l}68352 \\
0.6506 \\
0.650\end{array}$ & $\begin{array}{r}147442 \\
1.053 \\
1.050\end{array}$ & $\begin{array}{l}227900 \\
50.077 \\
59.000\end{array}$ & $\begin{array}{r}40461 \\
17.026 \\
17.140\end{array}$ & $\begin{array}{r}1270 \\
1.460 \\
1.900\end{array}$ & $\begin{array}{r}1273 \\
0.670 \\
0.490\end{array}$ \\
\hline$N B S-91$ & $\begin{array}{l}969750 \\
10.543 \\
10.480\end{array}$ & $\begin{array}{r}220514 \\
3.290 \\
-1.000\end{array}$ & $\begin{array}{r}5530 \\
2.250 \\
0.000\end{array}$ & $\begin{array}{l}19051 \\
0.012 \\
0.020\end{array}$ & $\begin{array}{l}262026 \\
66.995 \\
67,530\end{array}$ & $\begin{array}{l}16015 \\
5.994 \\
6.010\end{array}$ & $\begin{array}{r}162 \\
0.010 \\
0.000\end{array}$ & $\begin{array}{r}115 \\
0.066 \\
0.020\end{array}$ \\
\hline-2 & $\begin{array}{r}214901 \\
1.550 \\
1.960\end{array}$ & $\begin{array}{r}204423 \\
40404 \\
40460\end{array}$ & $\begin{array}{l}29.00 \\
2.696 \\
2.640\end{array}$ & $\begin{array}{l}0.106 \\
0.504 \\
0.400\end{array}$ & $\begin{array}{l}272436 \\
69.478 \\
69.220\end{array}$ & $\begin{array}{r}41140 \\
19.741 \\
15.420\end{array}$ & $\begin{array}{r}673 \\
0.602 \\
0.750\end{array}$ & $\begin{array}{r}210 \\
0.196 \\
0.130\end{array}$ \\
\hline$S-1$ & $\begin{array}{l}50135 \\
10002 \\
0.020\end{array}$ & $\begin{array}{r}3701 \\
0.000 \\
0.000\end{array}$ & $\begin{array}{l}80752 \\
30.663 \\
0.040\end{array}$ & $\begin{array}{l}19565 \\
0.010 \\
0.010\end{array}$ & $\begin{array}{l}151657 \\
40.670 \\
40.600\end{array}$ & $\begin{array}{r}1306 \\
0.290 \\
0.280\end{array}$ & $\begin{array}{r}28431 \\
49.090 \\
49,020\end{array}$ & $\begin{array}{l}0.000 \\
0.004 \\
0.000\end{array}$ \\
\hline$B S-1 a$ & $\begin{array}{r}3455135 \\
39.152 \\
=1.000\end{array}$ & $\begin{array}{r}50205 \\
0.029 \\
-1.0001\end{array}$ & $\begin{array}{l}18132 \\
1.539 \\
1.079\end{array}$ & $\begin{array}{l}35013 \\
0.136 \\
0.160\end{array}$ & $\begin{array}{r}55263 \\
17.678 \\
-1.000\end{array}$ & $\begin{array}{r}11252 \\
4.147 \\
4.160\end{array}$ & $\begin{array}{r}1206 \\
11.478 \\
-1.000\end{array}$ & $\begin{array}{r}0116 \\
0.217 \\
-1.000\end{array}$ \\
\hline
\end{tabular}


Table A-4

Accuracy of X-ray Fluorescence Analyses

\begin{tabular}{|c|c|c|c|c|c|c|}
\hline \multirow[b]{2}{*}{ wt. \% } & \multicolumn{2}{|c|}{ NBS-91 } & \multicolumn{2}{|c|}{ DTS-1 } & \multicolumn{2}{|c|}{$\mathrm{BCR}-1$} \\
\hline & A & B & A & B & A & B \\
\hline $\mathrm{SiO}_{2}$ & 67.59 & $67 \cdot 53$ & $40 \cdot 66$ & $40 \cdot 45$ & $55 \cdot 20$ & $54 \cdot 48$ \\
\hline $\mathrm{TiO}_{2}$ & .04 & .02 & .03 & .02 & $2 \cdot 20$ & $2 \cdot 23$ \\
\hline $\mathrm{Al}_{2} \mathrm{O}_{3}$ & $6 \cdot 37$ & 6.01 & 47 & .55 & $13 \cdot 80$ & $13 \cdot 65$ \\
\hline $\mathrm{Fe}_{2} \mathrm{O}_{3}(\mathrm{~T})$ & $\cdot 32$ & .08 & 8.89 & 8.85 & $13 \cdot 31$ & $13 \cdot 50$ \\
\hline $\mathrm{MgO}$ & $\cdot 28$ & - & $50 \cdot 71$ & $49 \cdot 80$ & $3 \cdot 43$ & $3 \cdot 28$ \\
\hline $\mathrm{CaO}$ & 10.63 & $10 \cdot 48$ & .06 & $\cdot 25$ & $7 \cdot 24$ & 6.95 \\
\hline $\mathrm{P}_{2} \mathrm{O}_{5}$ & .06 & .02 & .01 & .01 & 0.38 & 0.36 \\
\hline $\mathrm{K}_{2} \mathrm{O}$ & $3 \cdot 32$ & $3 \cdot 25$ & .00 & .02 & $1 \cdot 76$ & 1.68 \\
\hline
\end{tabular}

A: Data obtained during present study

B: Data given by Flanagan (1969).

$\mathrm{Fe}_{2} \mathrm{O}_{3}(\mathrm{~T})=$ total iron as $\mathrm{Fe}_{2} \mathrm{O}_{3}$. 
A. 3. Wet chemical methods

$\mathrm{P}_{2} \mathrm{O}_{5}$ was determined on twelve specimens using the colorimetric method of Baadsgaard and Sandell (1954). However, because of the acceptable precision and accuracy of the X-ray fluorescence method (Tables $\mathrm{A}-3$ and $\mathrm{A}-4$ ), all further $\mathrm{P}_{2} \mathrm{O}_{5}$ analyses were made by this shorter method.

Ferrous iron was determined by the method of Wilson (1955), viz. cold HF attack of the rock powder in the presence of excess ammonium vanadate in plastic crucibles for about five days, and titration of the excess vanadate with ferrous ammonium sulfate in the presence of borlc acid and sulphuric acid, using sodium diphenylamine sulphonate as indicator. The accuracy of this method was tested on the USGS standard basalt $B C R-1$, and the results are presented in Table A-5, column a. Precision of the method was determined from $\mathbf{s i x}$ duplicate analyses of No. 1 over a period of two months, during which time all other FeO analyses were made (Table A-5, column b). The precision was also calculated from the differences between duplicates on many different samples, as outlined by Gould (1966, p. 49), viz. if

$$
\begin{aligned}
& x_{1}, x_{2}=\text { two determinations on a single sample, } \\
& \bar{x}=\text { mean of a number of determinations, } n \text {, and } \\
& s=\text { standard deviation from the mean, then } \\
& s^{2}=\frac{\sum(x-\bar{x})^{2}}{n-1}=\frac{\left(x_{1}-x_{2}\right)^{2}}{2} \text { and } s=\frac{x_{1}-x_{2}}{\sqrt{2}}
\end{aligned}
$$

The precision can thus be estimated by averaging $\left(x_{1}-x_{2}\right) / \sqrt{2}$ for all the pairs of duplicate analyses. The results of this method 


\section{Table A-5}

Preaision and accuracy of ferrous iron analyses

\begin{tabular}{lccc}
\hline & a & b & c \\
\hline FeO obtained & 8.90 & & \\
FeO accepted & 8.91 & & \\
& & & \\
$\bar{x}$ & $9 \cdot 16$ & $9 \cdot 00$ \\
R & .48 & .34 \\
s & .084 & .067 \\
C & 12 & $.92 \%$ \\
n & & 72 \\
\hline
\end{tabular}

a. Comparison of $\mathrm{FeO}$ content obtained for $\mathrm{BCR}-1$ with that accepted by Flanagan (1969).

b. Precision of method calculated from repeat analyses of No.1

c. Precision of method calculated from differences between duplicate analyses of different rocks.

$\overline{\mathrm{x}}=$ mean $\mathrm{F} \theta \mathrm{O}$ concentration

$\mathrm{R}=$ range $=$ maximum-minimum $\mathrm{FeO}$ concentration

$\mathrm{s}=$ standard deviation from the mean

$c=$ coefficient of variation (relative deviation $=100 \mathrm{~s} / \bar{x}$ )

$n=$ number of duplicate determinations 
of calculation are given in Table A-5, column $c$, and it can be seen that both methods of calculation yield similar results.

All $\underline{\mathrm{Na}}_{2} \mathrm{O}$ and twelve $\underline{\mathrm{K}}_{2} \mathrm{O}$ determinations were carried out on an Evans Electroselenium Ltd. Model A flame photometer. The $\mathrm{K}_{2} \mathrm{O}$ results determined by $\mathrm{X}$-ray fluorescence were found to be satisfactory, however, so the faster X-ray method was used for all subsequent determinations of $\mathrm{K}_{2} \mathrm{O}$. Two methods were used to prepare sample solutions for flame photometry, as outlined in Figure A-3. Method $\underline{A}$, introduced by E.L.P. Mercy, was that commonly used in the Grant Institute, and was used by the writer for the first twelve samples, producing the precision shown in Table A-6, colurn a. However, M.J. Saunders suggested that Ca interference would be removed by allowing solid $\mathrm{CaSO}_{4}$ to settle to the bottom of the flask, and using a double Na filter on the photometer. This cuts out the tedious steps 3 and 5 , ignition and filtration, and therefore two possible sources of error. Comparison of columns a and $\underline{\mathrm{b}}$, Table A-6, shows that both methods have comparable precision. Precision of method B was also calculated from duplicates, column $\underline{c}$, as outlined for Feo precision, and from six analyses of BCR-1, column d. The accuracy of the method may be seen from the analyses of $\mathrm{BCR}-1$, column $d$, to be within the limits or precision. 


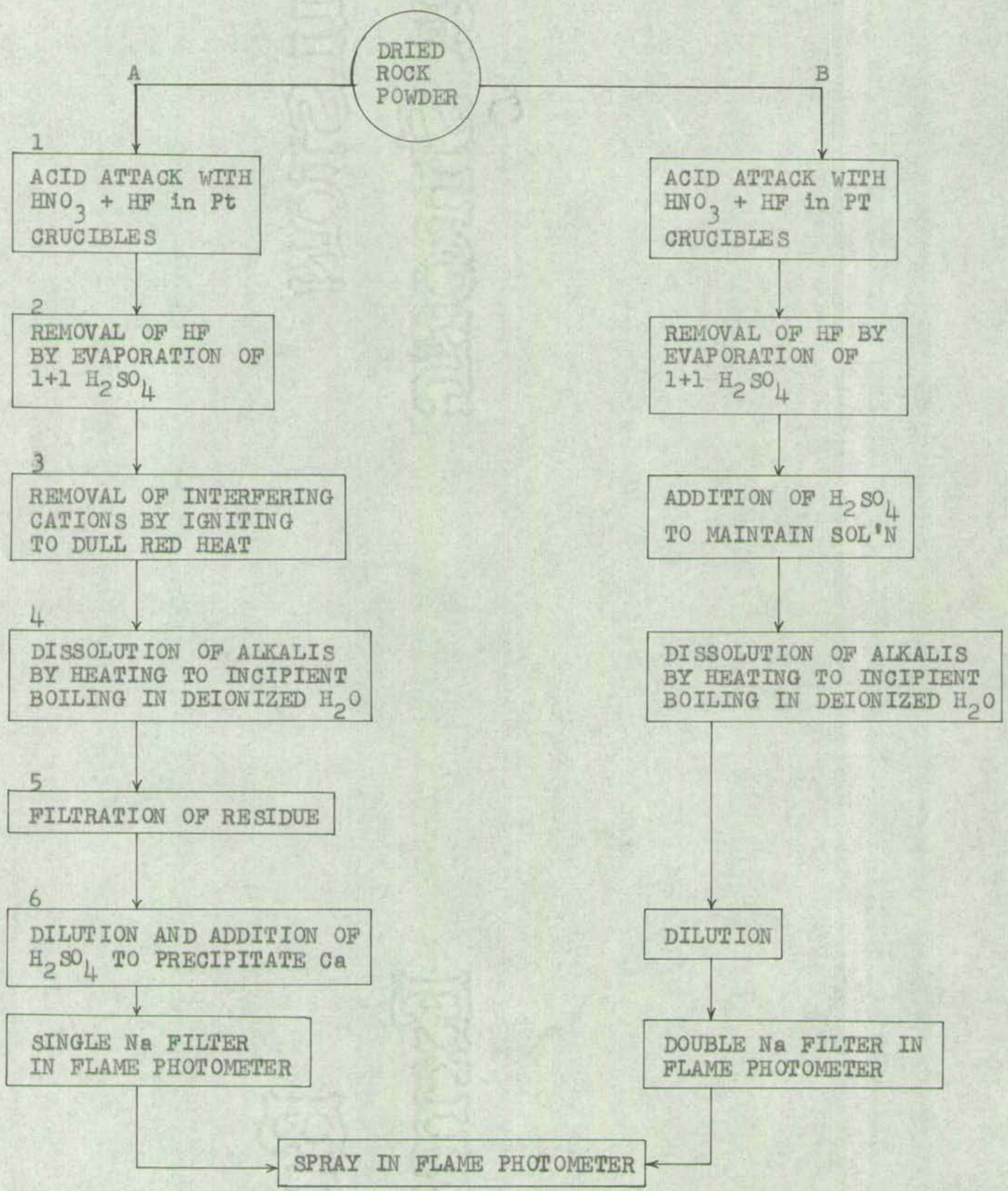




\section{Table A-6}

Preclsion and accuracy of $\mathrm{Na}_{2} 0$ analyses

\begin{tabular}{ccccc}
\hline & $a$ & $b$ & $c$ & $a$ \\
\hline $\begin{array}{cccc}\text { ACCEPTED } \\
\bar{x}\end{array}$ & 2.85 & $2 \cdot 90$ & 3.00 & $3 \cdot 29$ \\
$\mathrm{R}$ & .23 & .24 & .10 & $\cdot 12$ \\
$\mathrm{~s}$ & .069 & .078 & .043 & .042 \\
$\mathrm{c}$ & $2 \cdot 4 \%$ & $2 \cdot 7 \%$ & $1.4 \%$ & $1.3 \%$ \\
$\mathrm{n}$ & 6 & 12 & 17 & 6 \\
\hline
\end{tabular}

a. Precision of method A calculated from repeat analyses of No.1.

b. Precision of method B calculated from repeat analyses of No.1.

c. Precision of method B calculated from differences between duplicate analyses of different samples.

d. Comparison of $\mathrm{Na}_{2} \mathrm{O}$ content obtalned for BCR-1 with that accepted by Flanagan (1969), and preclsion of method B calculated from this data.

$\bar{x}=$ Mean $\mathrm{Na}_{2} \mathrm{O}$ concentration

$\mathrm{R}=\mathrm{Range}=\max i \mathrm{mum}-\mathrm{minimum}$ concentration

$s=$ standard deviation from the mean

$c=$ coefficient of variation

$\mathrm{n}$ = number of determinations 
$\mathrm{H}_{2} \mathrm{O}$ was determined by a modified version of the method described by Shapiro and Brannock (1962). It consists of fusing one gram of the rock powder with three grams of lead oxide-lead chromate flux, collecting the evolved water on pre-dried, preweighed filter paper, and weighing the fllter paper plus condensed water. The preoision of this method is shown in Table A-7. 


\section{Table A-?}

Precision of $\mathrm{H}_{2} \mathrm{O}$ Analyses

\begin{tabular}{ccc}
\hline & $a$ & $b$ \\
\hline $\bar{x}$ & $\cdot 43$ & $\cdot 40$ \\
$R$ & .09 & $\cdot 17$ \\
s & .08 & .04 \\
c & $20 \%$ & $10 \%$ \\
n & 6 & 99 \\
\hline
\end{tabular}

a. Precision of method calculated from repeat analyses of No.l

b. Precision of method calculated from differences between duplicate analyses of other rooks.

$\bar{x}=$ mean concentration

$\mathrm{R}=$ range $=$ maximum - minimum concentration

$\mathbf{s}=$ standard deviation from the mean

$c=$ coefficient of variation

$\mathrm{n}=$ number of duplicate determinations 
A.4. Electron mioroprobe analys $1 \mathrm{~s}$

The mioroprobe analyses (Appendix B) were camied out at Durham University under the direction of Dr. C.H. Emeleus. The standards used were minerals close to the unknowns in composition, and after correction for instrument drift, linear calibrations were assumed. The error in this method is thought to be $\pm 2 \%$ of the values obtained for $\mathrm{CaO}, \mathrm{MgO}$, and $\mathrm{FeO}$ (total), $\pm 5 \%$ of $\mathrm{MIO}_{2}$ values, and $\pm 10 \%$ of the $\mathrm{Na}_{2} \mathrm{O}$ and $\mathrm{K}_{2} \mathrm{O}$ values. (Dr. Emeleus, pers. comm.). A.5. Optical determinations

Estimates of An contents of plagioclases were made according to the Michel Levy method on both the universal stage and flat stage, and some were also determined using the high temperature $2 \mathrm{~V}$ curves of Smith (1958).

Refractive indices of olivines were measured on orushed grains in sodium light.

A.6. Modal analysis

Modal analyses were earried out using the "Shadowmaster" light table, on which an Image of the thin section is projected onto an 18 " glass plate. Points were counted by means of a $1 \mathrm{~cm}$. grid, using at least 400 points for each rock. The reliability of this method was ohecked against the standard techniques using the mechanical stage and counting from 2000 to 5000 points. The results, shown diagrammatically in Fig. A-4, indicate that the only signifioant discrepancy arlses from clinopyroxene counts. 
Fig. A-4.

Comparison of modal data obtained using the shadowmaster with that obtained using the mechanical stage. Numbers indicate volume percent of different phases.

- = olivine phenocrysts
$\Delta \quad=$ clinopyoxene phenoerysts
0 = plagioclase phenocrysts
- = groundmass. 


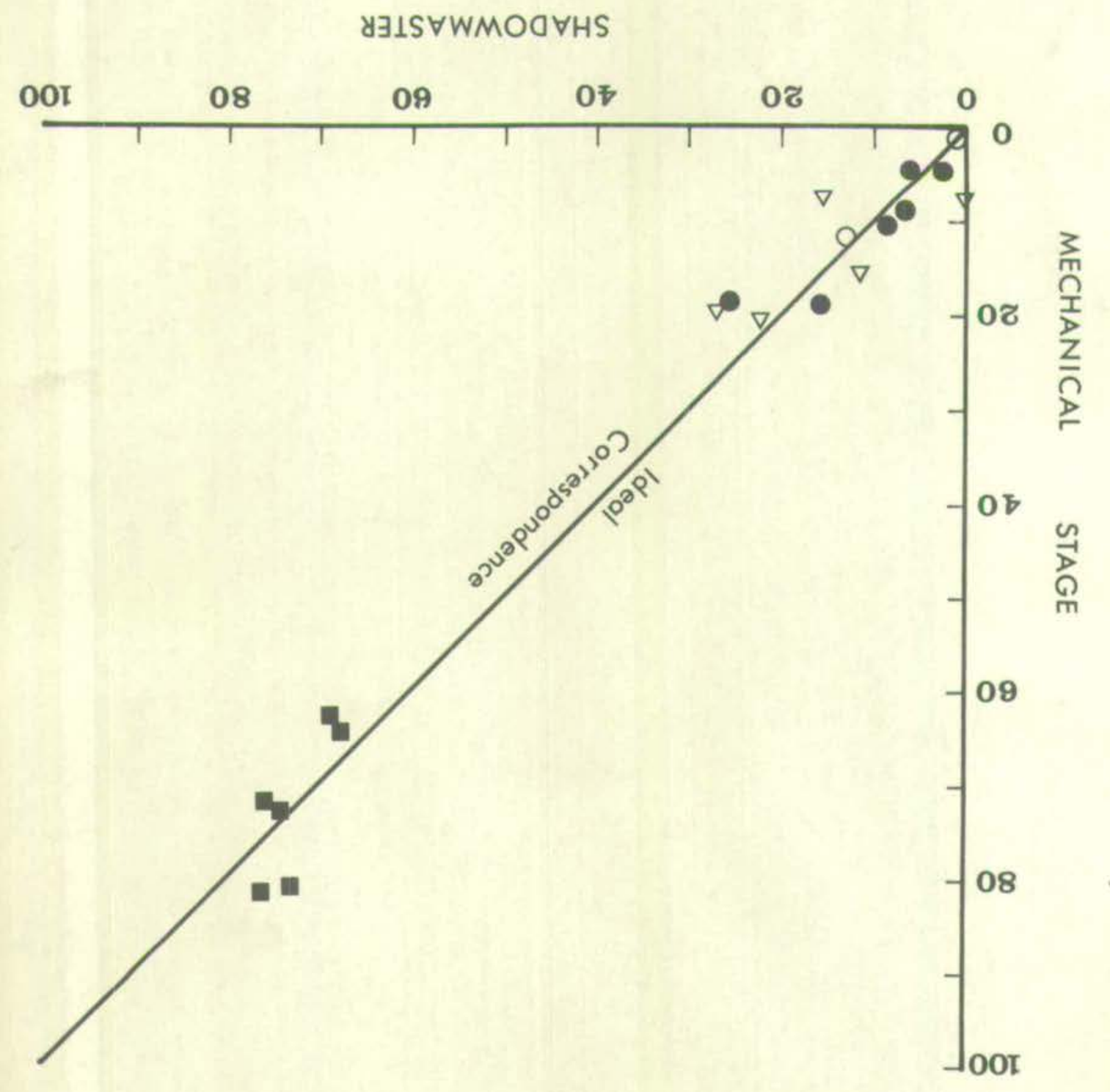


This is most likely a result of augite being mistaken for olivine during point counting on the mechanical stage, as this is unlikely to happen with the shadow master. This witer feels that results obtained from the shadowmaster are in fact more reliable than those obtained from the mechanical stage. The method was particularly well-sulted to the present study because of the large size of phenocrysts in some thin sections, and the full view of thin sections that is projected permits rapid distinction between phenocryst and groundmass minerals and between different types of phenocrysts (0.8. xenocrysts, skeletal crystals, and euhedral crystals). Furthermore, it has the great advantage of being about five times more rapld than the mechanical stage.

A.7. Olivine $x$-ray diffraction method

Olivines were determined according to the method of yoder and Sahama (1957), which they estimate as accurate to $\pm 4 \%$. 
$\underline{\text { References oited }}$

BAADSGAARD, H. and SANDELL, E.B. 1954. Photometric determination of phosphorus in silicate rocks. Analytica chim. Acta, 11, 183-187.

FLANAGAN, F.J. 1969. U.S. Geological Survey Standards - II. First compliation of data for the new U.S.G.S. rocks. Geochim. cosmochim. Acta, 33, 81-120.

GOULD, D. 1966. Geochemical and mineralogical studies of the granitic gneiss and associated rocks of Western Ardgour, Argy 11. Univ. Edinburgh Ph.D. Thesis (unpubl.).

HOLLAND, J.G. 1966. A self-consistent mass absorption correction for silicate analysis by X-ray fluorescence. Spectrochimios Acta, 22, 2083-2093.

NORRISH, K. and HUTTON, J.T. 1969. An accurate X-ray spectrographic method for the analysis of a wide range of geological samples. Geochim. cosmochim. Acta, 33, 431-454.

ROSE, H.J., ADLER, I. and FLANAGAN, F.J. 1963. X-ray fluorescence analysis of the light elements in rocks and minerals. Appl. Spectrosc., 17, 81-85.

SHAPIRO, L. and BRANNOCK, W.W. 1962. Rap1d analysis of sillcate, carbonate and phosphate rocks. U.S. Geol. Surv. Bull. $1144-\mathrm{A}$.

SMITH, J.V. 1958. Ef fect of temperature, structural state and composition of the albite, pericline and acline-A twins of plagioclase feldspars. Am. Miner. 43. 546-551.

THORNTON, C.P. and TUTTLE, O.F. 1960. Chemistry of Igneous rocks I: Differentiation Index. Am. J. So1. 258, 664-684.

WAGER, L.R. and BROWN, G.M. 1960. Collection and preparation of material for analyses, in Methods in geochemistry, eds. Smales, A.A. and Wager, L.R. Intersoience, New York and London; 4-32.

WILSON, A.D. 1955. A new method for the determination of ferrous iron in rocks and minerals. Bull. geol. Surv. Gt. Br., 2, 56-58.

YODER, H.S.Jnr. and SAHAMA, T.G. 1957. Olivine X-ray determinative curve. Am. Miner., 42, 475-491. 


\section{APPENDIX B}

Tables of Petrograph1c Data

B.1. Kartala lavas

B.2. La Grille lavas

B. 3. Badjini lavas

B.4. Kartala intrusive rocks

B.5. Miscellaneous rocks 
Table B-1

Potrography of analysed lava flows from Kartala

\begin{tabular}{|c|c|c|c|c|c|c|c|c|c|c|}
\hline $\begin{array}{l}\text { Rook } \\
\text { No. }\end{array}$ & $\begin{array}{l}\text { Rook } \\
\text { Type }\end{array}$ & $\frac{\text { Volume } 8}{0110 \ln \theta}$ & $\frac{\text { Phenoc }}{\text { Augite }}$ & 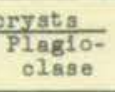 & $\begin{array}{l}\text { Volume } \\
\text { \& Ves- } \\
\text { Ielea }\end{array}$ & $\frac{\text { Groundm }}{\text { O11vine }}$ & $\frac{\text { mass min }}{\text { Augite }}$ & 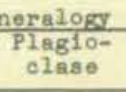 & Ore & Comments \\
\hline 1 & Ankaramito & $7 \cdot 6$ & 8.9 & - & 0 & $x$ & $x$ & An -48 & $\mathrm{x}$ & \\
\hline 4 & Alkal1 basalt & $2 \cdot 0$ & - & - & $5 \cdot 8$ & $\mathrm{x}$ & $x$ & $\mathrm{x}$ & $\mathrm{x}$ & $\begin{array}{l}\text { m1crophenocrysts } 4 \cdot 3 \% \text { ol., } 19 \cdot 6 \% \mathrm{cpx} \text {, } \\
11.6 \% \text { plag of An-60. glassy ground- } \\
\text { mass; from } 1872 \text { flow. }\end{array}$ \\
\hline 6 & $\begin{array}{l}\text { Alkall bassit } \\
\text { glasay chill }\end{array}$ & - & - & - & $\sim 50 \%$ & $\mathrm{x}$ & $x$ & $x$ & - & R.I. of glass $=1.610$; from 1872 flow. \\
\hline 8 & $\begin{array}{l}\text { Alkall olivine } \\
\text { basalt }\end{array}$ & $7 \cdot 0$ & - & - & $22 \cdot 6$ & - & $x$ & $x$ & $x$ & from 1859 flow \\
\hline 13 & Ankaramite & $16 \cdot 5$ & $20 \cdot 0$ & - & - & - & $\mathrm{x}$ & An -55 & $\mathrm{x}$ & $\begin{array}{l}\text { Blook in N'Goun1 vuff cone. Minor } \\
\text { resorption of both ollivine snd augite. }\end{array}$ \\
\hline 17 & Ocesilte & $14 \cdot 5$ & $4 \cdot 8$ & - & - & $x$ & $x$ & $A n-48$ & $\mathrm{x}$ & $\begin{array}{l}\text { Cosrse dolerit } 10 \text { groundmass. Ores } \\
\text { elongate }(=11 \text { man } 1 \text { te? })\end{array}$ \\
\hline 18 & Oceanite & $36 \cdot 9$ & 3.6 & - & - & - & $\mathrm{x}$ & $x$ & $x$ & as above \\
\hline 19 & Oceani te & $22 \cdot 0$ & $14 \cdot 3$ & - & - & - & $x$ & $x$ & $\mathrm{x}$ & as above \\
\hline 20 & Alkall basalt & 2.5 & 0.3 & - & 0 & $x$ & $x$ & $x$ & $x$ & strong fluidel texture; coarse groundmass \\
\hline 21 & Oceanite & $21 \cdot 0$ & $11 \cdot 7$ & - & - & $x$ & $\mathrm{x}$ & $x$ & $\mathrm{x}$ & $\begin{array}{l}\text { Cosrse dolerite groundmess. Blongate ore } \\
\text { mlerophenoorysts. olivine phenoorysts. } \\
\text { resorbed. Augites zoned. gabbroic lnciusion }\end{array}$ \\
\hline 22 & Alkall basalt & $2 \cdot 0$ & $2 \cdot 5$ & - & - & $x$ & $\mathrm{x}$ & An -58 & $\mathrm{x}$ & 2857 flow \\
\hline 23 & $\begin{array}{l}\text { Alkali olivine } \\
\text { basalt scoria }\end{array}$ & $7 \cdot 8$ & $5 \cdot 9$ & - & $21 \cdot 8$ & $\mathrm{x}$ & $\mathrm{x}$ & $x$ & - & R.I. of glass $=1.606$ \\
\hline 214 & Alkall basalt & - & $4 \cdot 3$ & - & $23 \cdot 9$ & $x$ & $x$ & $x$ & $x$ & 1859 flow \\
\hline 25 & Ajkall basalt & - & - & 1.5 & 0 & - & $x$ & $x$ & $\mathrm{x}$ & $\begin{array}{l}\text { Mlorophenocryst of olivine, sugite, } \\
\text { plag. }(=\text { An }-60) \text { 1858 flow, upper end. }\end{array}$ \\
\hline 26 & Alkali basalt & $2 \cdot 6$ & 1.9 & - & $2 \cdot 3$ & - & $x$ & An-55 & $\mathrm{x}$ & 1858 flow, lower end \\
\hline $27(2)$ & Alke11 baselt & - & - & - & $23 \cdot 7$ & $\mathrm{x}$ & $x$ & $\mathbf{x}$ & $x$ & \\
\hline 28 & Alkal1 basalt & - & - & - & - & $x$ & $x$ & An -55 & $x$ & plag1oclase mlorophenocrysts $=$ An -68 . \\
\hline 29 & Alkall basalt & - & - & - & - & $\mathrm{x}$ & $x$ & $x$ & $\mathrm{x}$ & \\
\hline 31 & Ankaramite & $12 \cdot 8$ & $27 \cdot 6$ & - & $8 \cdot 9$ & - & $\mathrm{x}$ & $x$ & $x$ & * \\
\hline 32 & Alkall basalt & $2 \cdot 6$ & 1.9 & - & $2 \cdot 5$ & - & $x$ & An -55 & $x$ & $\begin{array}{l}\text { Olivines akeletal in } g^{\prime} \text { mass; aome pheno- } \\
\text { oryata show resorption. Pluidal } \\
\text { texture; } 190 \text {. flow. }\end{array}$ \\
\hline 39 & Alkall basalt & $1 \cdot 4$ & - & - & $13 \cdot 3$ & $x$ & $x$ & $x$ & $x$ & $\begin{array}{l}\text { Groundmass rich in plag.; few plag. and } \\
\text { augite miorophenocrysts. }\end{array}$ \\
\hline 40 & Alkall basalt & - & $2 \cdot 1$ & 3.6 & $2 \cdot 8$ & - & $x$ & An -5 ? & $x$ & $\begin{array}{l}\text { Plag. and augite phenoorysti form } \\
\text { glomeritio aggregates. dunitio } \\
\text { Inclusion. }\end{array}$ \\
\hline 41 & Inkaram1 te & 9.6 & $12 \cdot 0$ & - & $16 \cdot 6$ & $x$ & $\mathrm{x}$ & $\mathrm{x}$ & $\mathrm{x}$ & $\begin{array}{l}\text { Olivine phenoorysts mostly euhedral, } \\
\text { some resorbed. augite strongly zoned; } \\
1860 \text { flow. }\end{array}$ \\
\hline
\end{tabular}


Table B-1 (Contd.)

\begin{tabular}{|c|c|c|c|c|c|c|c|c|c|c|c|}
\hline $\begin{array}{l}\text { Rook } \\
\text { No. }\end{array}$ & $\begin{array}{l}\text { Rock } \\
\text { Type }\end{array}$ & & oolume & $\frac{6 \text { Phenoer }}{\text { Augite } 1}$ & $\begin{array}{c}\text { Prysts } \\
\text { Plagio- } \\
\text { clase }\end{array}$ & $\begin{array}{l}\text { Volume } \\
\text { \$. Ves- } \\
\text { loles }\end{array}$ & $\frac{\text { Groundme }}{011 \text { inine }}$ & $\frac{\text { ass mine }}{\text { Augite }}$ & $\begin{array}{l}\text { eralogy } \\
\text { Plag10- } \\
\text { olase }\end{array}$ & Ore & Comments \\
\hline 45 & Alkall & basalt & $1 \cdot 0$ & - & - & 0 & $x$ & $\mathrm{x}$ & $x$ & $x$ & $\begin{array}{l}\text { Coarse dolerit1o groundmass with plag. } \\
\text { interstitial. groundmass apatite. }\end{array}$ \\
\hline 46 & $\begin{array}{l}\text { Alka11 } \\
\text { sooria }\end{array}$ & basalt & & & & 40.0 & $x$ & $x$ & $x$ & - & $\begin{array}{l}\text { R.I. of glass }=1.610,2 \% \text { oxidized } \\
\text { gabbrolo inclusions. }\end{array}$ \\
\hline 47 & Alkal1 & basalt & - & - & - & $6 \cdot 0$ & $x$ & $x$ & $x$ & $x$ & $\begin{array}{l}\text { Coarse doleritio groundmass, similar } \\
\text { to } 45 \text {. groundmass apatite. }\end{array}$ \\
\hline 48 & Alkal1 & basalt & - & $1 \cdot 4$ & $1 \cdot 4$ & $29 \cdot 3$ & $x$ & $x$ & $x$ & $x$ & as above \\
\hline 101 & A.kal1 & basalt & - & - & - & $24 \cdot 0$ & $x$ & $x$ & $x$ & $x$ & as above \\
\hline 102 & Alkall & basalt & - & - & - & 0 & $x$ & $x$ & $x$ & $x$ & as above \\
\hline 103 & $\begin{array}{l}\text { Alkal1 } \\
\text { acorla }\end{array}$ & basalt & $3 \cdot 9$ & - & - & $28 \cdot 8$ & $x$ & $x$ & $x$ & - & $\begin{array}{l}\text { Augite and plag. miorophenoorysts elus- } \\
\text { tered into rosettes. Blassy groundmass. }\end{array}$ \\
\hline 112 & A]kal1 & basalt & - & - & - & $24 \cdot 2$ & $x$ & $x$ & $x$ & $x$ & \\
\hline 113 & Alkal1 & basalt & - & - & - & $45 \cdot 8$ & $x$ & $x$ & $x$ & $x$ & 1860 rlow \\
\hline 119 & $\underset{\text { Acor18 }}{\text { Alkal1 }}$ & basalt & tr & - & - & $40 \cdot 2$ & $x$ & $x$ & $x$ & - & Olivines skeletal, much brown glass. \\
\hline 122 & $\begin{array}{l}\text { Alkal1 } \\
\text { sooria }\end{array}$ & basalt & - & - & - & $45 \cdot 7$ & $x$ & $x$ & $x$ & - & as above \\
\hline 123 & $\begin{array}{l}\text { Alkal1 } \\
\text { scorla }\end{array}$ & basalt & - & - & - & 50.0 & $x$ & $x$ & $x$ & - & ; 1965 rlow \\
\hline 134 & $\begin{array}{l}\text { Alkali } \\
\text { basalt }\end{array}$ & ollvine & $2 \cdot 0$ & $6 \cdot 0$ & - & $35 \cdot 3$ & $x$ & $x$ & $x$ & $x$ & 1862 flow \\
\hline 139 & Alkall & basalt & 0.4 & $1 \cdot 8$ & - & $35 \cdot 5$ & $x$ & $x$ & $x$ & $x$ & 1857 flow \\
\hline 142 & Alkali & basalt glass & $38-$ & - & - & $>50 \%$ & $x$ & $x$ & - & - & $\begin{array}{l}\text { very glassy (>95\%), oelluler struoture, } \\
\text { crystals of ollvine and augite. }\end{array}$ \\
\hline 151 & Ocean 1t & & $27 \cdot 7$ & $8 \cdot 6$ & - & $4 \cdot 9$ & $x$ & $x$ & $x$ & $x$ & $\begin{array}{l}\text { slight resorption of larger phenoorysta; } \\
1880 \mathrm{Nl} \text { ow }\end{array}$ \\
\hline 154 & Alkall & basalt & 1.6 & - & - & $12 \cdot 0$ & $x$ & $x$ & $x$ & $x$ & \\
\hline 160 & Alkal1 & basalt & $1 \cdot 4$ & - & - & $5 \cdot 3$ & $x$ & $x$ & $x$ & $x$ & $\begin{array}{l}1857 \text { flow } \\
\text { glassy oroundmasa: } 1860 \text { flow }\end{array}$ \\
\hline 186 & Ankaram & mito & $5 \cdot 4$ & $17 \cdot 3$ & - & $35 \cdot 6$ & $x$ & $x$ & $x$ & $x$ & glassy groundmasa; 1860 flow \\
\hline 188 & $\begin{array}{l}\text { Poldapa } \\
\text { basalt }\end{array}$ & ar-phyrio & $2 \cdot 1$ & $4 \cdot 2$ & $12 \cdot 8$ & 16.0 & $x$ & $x$ & $x$ & $x$ & \\
\hline 190 & Alkal1 & ollvine & $3 \cdot 4$ & $3 \cdot 4$ & - & $4 \cdot 5$ & $x$ & $x$ & $\mathbf{x}$ & $\boldsymbol{x}$ & \\
\hline 194 & Ankaram & m1te & $8 \cdot 2$ & $24 \cdot 6$ & - & 0 & $x$ & $x$ & $x$ & $x$ & doler1t10 g'mass \\
\hline 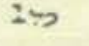 & Oesean1t & & $16 \cdot 6$ & $16 \cdot 3$ & - & - & $\mathbf{x}$ & $x$ & $x$ & $x$ & \\
\hline
\end{tabular}


Table B-2

Petrography of analysed lava Plows from La Grillo

\begin{tabular}{|c|c|c|c|c|c|c|c|c|c|c|c|c|c|}
\hline \multirow{2}{*}{$\begin{array}{l}\text { Rook } \\
\text { No. }\end{array}$} & \multirow{2}{*}{\multicolumn{2}{|c|}{ Rook Type }} & \multirow{2}{*}{\multicolumn{2}{|c|}{$\begin{array}{l}\text { Volume } \% \\
\text { Phenocrysts } \\
\text { OIfIne Augite }\end{array}$}} & \multirow{2}{*}{$\begin{array}{l}\text { Yolume } \\
\text { of Ves- } \\
\text { 1oles }\end{array}$} & \multicolumn{6}{|c|}{ Groundmass mineralogy } & \multirow{2}{*}{$\begin{array}{l}\text { U1tra- } \\
\text { mafic } \\
\text { inclu- } \\
\text { sions }\end{array}$} & \multirow{2}{*}{ Comments } \\
\hline & & & & & & olivine & Augite & Plag. & Ores & Neph. & Glasa & & \\
\hline 9 & bsanite & & $15 \cdot 0$ & $\mathrm{tr}_{\mathrm{F}}$ & 8.0 & $\mathrm{x}$ & $x$ & $x$ & $\mathrm{x}$ & $x$ & $x$ & - & $\begin{array}{l}\text { amall red spinel octahedra } \\
\text { common, some elongate ore } \\
\text { microphenocrygts. some sikel- } \\
\text { etal ollvine }\end{array}$ \\
\hline 10 & basanite. & & $10 \cdot 6$ & - & $15 \cdot 6$ & $x$ & $x$ & 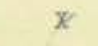 & $x$ & $\mathrm{x}$ & $\mathrm{x}$ & - & as above. \\
\hline 36 & nepheline & bassit & $8 \cdot 8$ & - & $4 \cdot 5$ & $x$ & $x$ & - & $x$ & $\mathrm{x}$ & $x$ & $\mathrm{x}$ & $\begin{array}{l}\text { Some ollvines deformed and } \\
\text { resorbed, some are large } \\
\text { skeletal orystals. Ore micro- } \\
\text { phenoorysta much glasa. } \\
\text { minor apatite. }\end{array}$ \\
\hline $37(2)$ & nepheline & basalt & $6 \cdot 7$ & $6 \cdot 3$ & 0 & $\mathrm{x}$ & $x$ & - & $x$ & - & $x$ & $\mathrm{x}$ & $\begin{array}{l}\text { Groundmass muoh finer than } \\
\text { above. Augite strongly zoned } \\
\text { and polysynthetically twinned }\end{array}$ \\
\hline 3713 & inepheline & basalt & $11 \cdot 9$ & - & 4.0 & $x$ & $x$ & - & $x$ & - & $x$ & $x$ & $\begin{array}{l}\text { Small red spinel octahedre. } \\
\text { Some ollvines deformed and } \\
\text { resorbed, some euhedral. }\end{array}$ \\
\hline 52 & basanite & & $1 \cdot 4$ & $1 \cdot 4$ & $31 \cdot 3$ & $\mathrm{x}$ & $x$ & $x$ & $\mathrm{x}$ & - & $x$ & - & $\begin{array}{l}\text { Olivine mostly euhedrsl, } \\
\text { some resorbed. some augites } \\
\text { have diopside cores. }\end{array}$ \\
\hline 53 & basanite & & $6 \cdot 1$ & $1 \cdot 3$ & - & $x$ & $\mathrm{x}$ & $x$ & $x$ & $x$ & - & $x$ & $\begin{array}{l}\text { ollvine mostiy euhedral but } \\
\text { some excellent skeletal } \\
\text { orystals. }\end{array}$ \\
\hline 54 & nephelline & baselt & $14 \cdot 8$ & - & $18 \cdot 0$ & $x$ & $x$ & - & $\mathrm{x}$ & $\mathrm{x}$ & - & $x$ & $\begin{array}{l}\text { Wich xenoorystal olivine; } \\
\text { some spinel; Inciplent wes- } \\
\text { thering near vesicles and orsole }\end{array}$ \\
\hline 55 & basanite & & 10.9 & - & $13 * 3$ & $x$ & $x$ & $x$ & $x$ & $x$ & - & $x$ & $\begin{array}{l}\text { Augites show oomplex inter- } \\
\text { growths; some ollvines resorbed } \\
\text { but generally euhedral; plag. } \\
\text { milorophenoorysts. }\end{array}$ \\
\hline 56 & nepheline & basalt & $13 \cdot 6$ & - & $7 \cdot 4$ & $\mathrm{x}$ & $x$ & - & $x$ & - & $x$ & $\mathrm{x}$ & $\begin{array}{l}\text { The complex exaolution pheno- } \\
\text { mena of the olfinines indicate } \\
\text { that this rook has undergone } \\
\text { severe hlgh temp. oxidation. }\end{array}$ \\
\hline 57 & basanite & & $10 \cdot 4$ & - & $30 \cdot 7$ & $x$ & $x$ & $x$ & $x$ & $x$ & - & - & slight resorption of ollvine \\
\hline 58 & basanite & & $4 \cdot 0$ & - & 0 & $x$ & $x$ & $x$ & $x$ & $x$ & - & $x$ & $\begin{array}{l}\text { Abundant } 11 \text { menite (?)micro- } \\
\text { phenocrysts. some red apinel } \\
\text { ootahedre. }\end{array}$ \\
\hline 59 & bosanite & & 7.5 & $4 \cdot 6$ & $17 \cdot 7$ & $x$ & $\mathrm{x}$ & $x$ & $x$ & $x$ & $x$ & - & $\begin{array}{l}\text { Coarse groundmass very riah in } \\
\text { plag. olivine sometimes rimmed } \\
\text { w1th sugite resldual liquid } \\
\text { on vesicle }\end{array}$ \\
\hline
\end{tabular}

(contd.) 
Table B-2 (Contd.)

\begin{tabular}{|c|c|c|c|c|c|c|c|c|c|c|c|c|}
\hline \multirow{2}{*}{$\begin{array}{l}\text { Rook } \\
\text { No. }\end{array}$} & \multirow[t]{2}{*}{ Rock Type } & \multirow{2}{*}{\multicolumn{2}{|c|}{$\begin{array}{l}\text { Volume } \% \\
\text { Phenocrystg } \\
\text { OIivine Augite }\end{array}$}} & \multirow{2}{*}{$\begin{array}{l}\text { Yolume } \\
\text { \& Ves- } \\
\text { Ioles }\end{array}$} & \multicolumn{6}{|c|}{ Groundmass mineralo } & \multirow{2}{*}{$\begin{array}{l}\text { oltra- } \\
\text { maflo } \\
\text { Inclu- } \\
\text { sions }\end{array}$} & \multirow[b]{2}{*}{ Comments } \\
\hline & & & & & ollvine & Aug1te & P1ag. & Ores & Neph. & Glass & & \\
\hline 165 & basanite & $9 \cdot 4$ & 1.9 & 13.0 & $\mathrm{x}$ & $x$ & $\mathrm{x}$ & $x$ & - & - & $x$ & $\begin{array}{l}\text { Some ollvine and augite re- } \\
\text { sorbed; sandstone inclusions } \\
\text { present }\end{array}$ \\
\hline 171 & nephellne basalt & 13.5 & - & $4 \cdot 8$ & $x$ & $x$ & - & $x$ & - & - & $x$ & \\
\hline 172 & basan1te & $10 \cdot 2$ & $1 \cdot 5$ & $26 \cdot 9$ & $x$ & $x$ & $x$ & $x$ & $x$ & $x$ & - & $\begin{array}{l}\text { Small fine grathed ollvine } \\
\text { glomeroory sts; ollvines re- } \\
\text { sorbed, have rare spinel } \\
\text { incluilions }\end{array}$ \\
\hline 173 & basanite & $11 \cdot 0$ & - & $12 \cdot 1$ & $x$ & $x$ & $x$ & $x$ & - & $x$ & $x$ & $\begin{array}{l}\text { Abundant red spinel } \\
\text { ootahedra }\end{array}$ \\
\hline 178 & nephellne basalt & $<1 \%$ & $<1 \%$ & $24 \cdot 1$ & $x$ & $x$ & - & $x$ & - & $x$ & - & $\begin{array}{l}\text { Very glass (= } 11 \text { mburgite). } \\
\text { some olivine resorbed, but } \\
\text { mostly skeletel. Augite } \\
\text { in rosettes. }\end{array}$ \\
\hline 192 & nephellne basalt & $10 \cdot 8$ & - & $21 \cdot 8$ & $x$ & $x$ & - & $x$ & - & $\mathrm{x}$ & - & $\begin{array}{l}\text { Olivines mostly large } \\
\text { skeletal orystals, } \\
\text { alangated, giving striking } \\
\text { fluidal texture. }\end{array}$ \\
\hline
\end{tabular}


Tables B-3; B- $4 ; \mathrm{B}-5$.

Potrogrephy of analysed rocks, other than lave flows, from Grande comore. Table B-3. Badjint laves

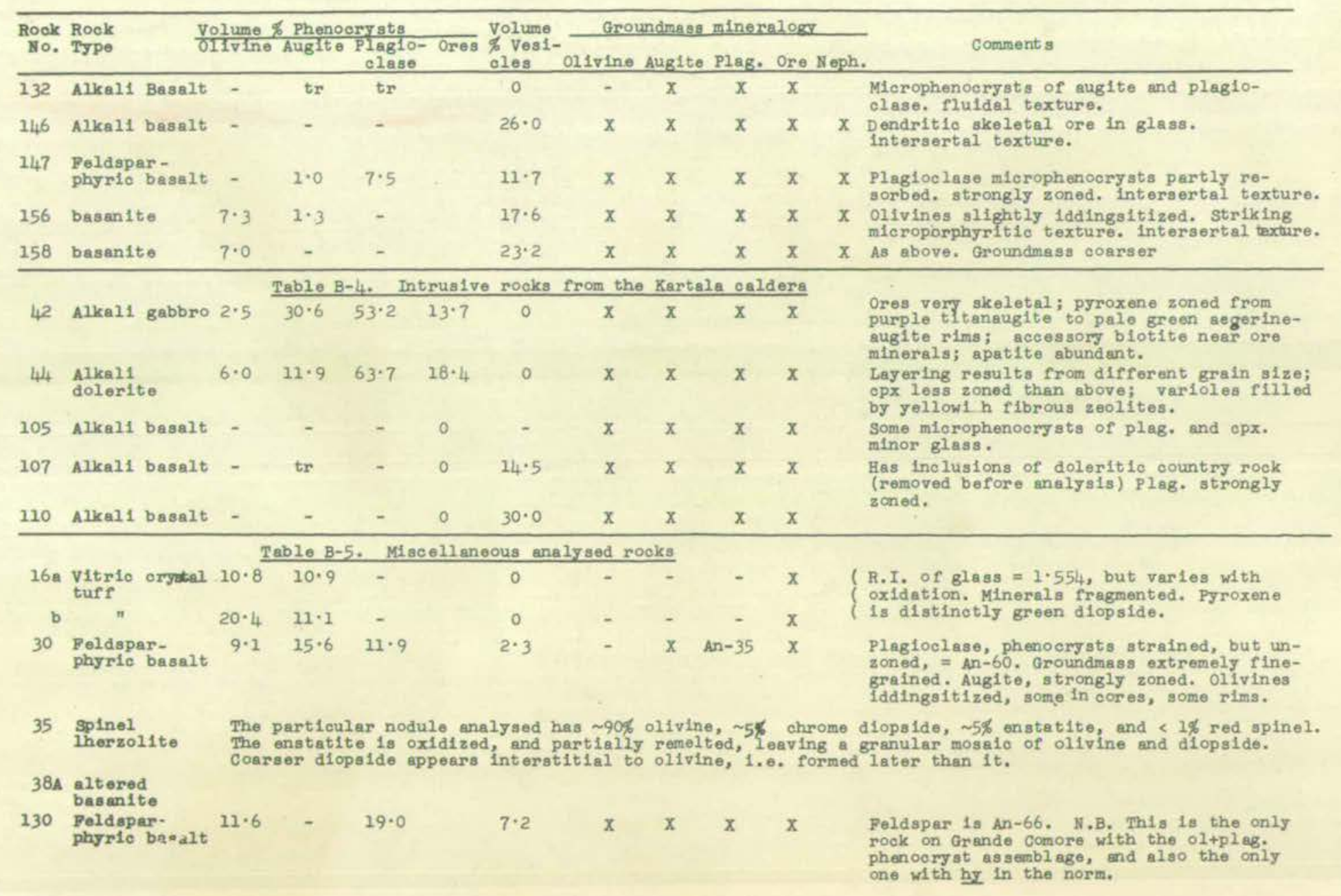




\section{APPENDIX C}

\section{Tables of chemical data}

c.1. Kartala lavas

C.2. La Grille lavas

c.3. Badjini lavas

c. 4. Kartala Intrusive rooks

0.5. Miscellaneous rocks

* Indicates that $\mathrm{Fe}_{2} \mathrm{O}_{3}$ has been reduced to 2.00 wt.\% before calculation of the norm.

D. I. = differentiation index (Thomton and Tuttle, 1960). 
Table $c-1$

Chemical Analysis of Lavas from Kartala

\begin{tabular}{|c|c|c|c|c|c|c|c|c|c|}
\hline & 1 & 4 & 6 & 8 & 13 & 17 & 18 & 19 & 20 \\
\hline $\mathrm{S}_{2}$ & $47 \cdot 12$ & $47 \cdot 30$ & $47 \cdot 45$ & $47 \cdot 99$ & $45 \cdot 40$ & $46 \cdot 05$ & $44 \cdot 91$ & $45 \cdot 85$ & $46 \cdot 60$ \\
\hline $\mathrm{THO}_{2}$ & $2 \cdot 32$ & $2 \cdot 56$ & $2 \cdot 29$ & $2 \cdot 55$ & $1 \cdot 60$ & 1.94 & $1 \cdot 49$ & 1.56 & 2.67 \\
\hline $\mathrm{Al}_{2} \mathrm{O}_{3}$ & $13 \cdot 20$ & $14 \cdot 68$ & $14 \cdot 19$ & $14 \cdot 32$ & $8 \cdot 46$ & 10.02 & $7 \cdot 78$ & $8 \cdot 14$ & $14 \cdot 40$ \\
\hline $\mathrm{Fe}_{2} \mathrm{O}_{3}$ & $2 \cdot 53$ & $2 \cdot 31$ & 1.69 & $3 \cdot 07$ & $3 \cdot 29$ & $1 \cdot 75$ & $2 \cdot 02$ & $2 \cdot 19$ & $4 \cdot 78$ \\
\hline $\mathrm{FeO}$ & $9 \cdot 16$ & $9 \cdot 29$ & $10 \cdot 22$ & $8 \cdot 21$ & $8 \cdot 42$ & $9 \cdot 80$ & $9 \cdot 76$ & $9 \cdot 73$ & $7 \cdot 89$ \\
\hline Mno & $\cdot 19$ & $\cdot 20$ & .19 & .20 & $\cdot 20$ & .19 & $\cdot 20$ & .19 & $\cdot 30$ \\
\hline 30 & $9 \cdot 38$ & $6 \cdot 66$ & $6 \cdot 69$ & $6 \cdot 65$ & $17 \cdot 43$ & $15 \cdot 60$ & $21 \cdot 07$ & $19 \cdot 66$ & $5 \cdot 92$ \\
\hline $\mathrm{CaO}$ & $11 \cdot 48$ & $11 \cdot 71$ & $12 \cdot 82$ & $11 \cdot 50$ & $11 \cdot 79$ & $10 \cdot 85$ & 9.07 & $9 \cdot 58$ & $11 \cdot 28$ \\
\hline $\mathrm{Na}_{2} \mathrm{O}$ & $2 \cdot 89$ & $3 \cdot 41$ & $3 \cdot 12$ & $3 \cdot 40$ & $1 \cdot 42$ & $2 \cdot 34$ & $1 \cdot 56$ & $1 \cdot 76$ & $3 \cdot 39$ \\
\hline $\mathrm{K}_{2} \mathrm{O}$ & $1 \cdot 24$ & $1 \cdot 44$ & $1 \cdot 12$ & $1 \cdot 32$ & .52 & .89 & $\cdot 48$ & .57 & $1 \cdot 28$ \\
\hline $\mathrm{P}_{2} \mathrm{O}_{5}$ & $\cdot 41$ & $\cdot 45$ & $\cdot 40$ & $\cdot 47$ & $\cdot 26$ & $\cdot 29$ & $\cdot 23$ & $\cdot 27$ & .39 \\
\hline $\mathrm{H}_{2} \mathrm{O}$ & $\cdot 42$ & $\cdot 25$ & $\cdot 14$ & $\cdot 38$ & .86 & $\cdot 71$ & $\cdot 49$ & $\cdot 31$ & 80 \\
\hline Total & $100 \cdot 34$ & $100 \cdot 26$ & $100 \cdot 32$ & 100.06 & 99.65 & $100 \cdot 43$ & 99.06 & $99 \cdot 81$ & $99 \cdot 70$ \\
\hline $\begin{array}{l}\text { Il } \\
\text { Ap } \\
\text { Rest }\end{array}$ & $\begin{array}{r}7 \cdot 32 \\
15 \cdot 86 \\
18.65 \\
5.37 \\
28.78 \\
15.05 \\
3.59 \\
4.40 \\
.97 \\
.42\end{array}$ & $\begin{array}{r}8.51 \\
16.48 \\
20.52 \\
6.70 \\
28.29 \\
10.24 \\
3.35 \\
4.86 \\
1.07 \\
.25\end{array}$ & $\begin{array}{r}6 \cdot 60 \\
14.93 \\
21 \cdot 35 \\
6 \cdot 18 \\
32 \cdot 48 \\
10 \cdot 72 \\
2 \cdot 44 \\
4.34 \\
.94 \\
.14\end{array}$ & $\begin{array}{r}7.82 \\
21.38 \\
19.97 \\
4.05 \\
27.71 \\
8.63 \\
4.46 \\
4.86 \\
1.12 \\
.38\end{array}$ & $\begin{array}{r}3.11 \\
11.58 \\
15.36 \\
.31 \\
33.53 \\
27.58 \\
4.83 \\
3.08 \\
.62 \\
.86\end{array}$ & $\begin{array}{r}5 \cdot 27 \\
10 \cdot 94 \\
14.25 \\
4.83 \\
30.35 \\
27.43 \\
2.54 \\
3.69 \\
.69 \\
.71\end{array}$ & $\begin{array}{r}2.88 \\
12.50 \\
22.99 \\
.48 \\
24.83 \\
39.92 \\
2.97 \\
2.87 \\
.55 \\
.49\end{array}$ & $\begin{array}{r}3.38 \\
13.74 \\
12.69 \\
.67 \\
26.59 \\
36.12 \\
3.19 \\
2.98 \\
.64 \\
.31\end{array}$ & $\begin{array}{r}7 \cdot 65 \\
21.39 \\
20.52 \\
4.12 \\
27.04 \\
6.22 \\
7.01 \\
5.13 \\
.93 \\
.80\end{array}$ \\
\hline $\begin{array}{l}\mathrm{Rb} \\
\mathrm{Cu} \\
\mathrm{Sr} \\
\mathrm{Ba} \\
\mathrm{Zn} \\
\mathrm{Zr} \\
\mathrm{Cr} \\
\mathrm{N} 1\end{array}$ & $\begin{array}{r}29 \\
102 \\
512 \\
381 \\
93 \\
201 \\
337 \\
212\end{array}$ & $\begin{array}{r}24 \\
90 \\
510 \\
520 \\
100 \\
270 \\
125 \\
55\end{array}$ & $\begin{array}{r}20 \\
101 \\
425 \\
470 \\
107 \\
188 \\
70 \\
77\end{array}$ & $\begin{array}{r}28 \\
80 \\
510 \\
430 \\
92 \\
228\end{array}$ & $\begin{array}{r}14 \\
93 \\
288 \\
280 \\
85 \\
121\end{array}$ & $\begin{array}{r}15 \\
85 \\
345 \\
240 \\
95 \\
138\end{array}$ & $\begin{array}{r}10 \\
73 \\
245 \\
200 \\
104 \\
110\end{array}$ & $\begin{array}{r}17 \\
73 \\
275 \\
220 \\
95 \\
120\end{array}$ & $\begin{array}{r}24 \\
76 \\
485 \\
360 \\
103 \\
220 \\
112 \\
90\end{array}$ \\
\hline
\end{tabular}

$\begin{array}{llllllllll}\text { DI } & 28.56 & 31.68 & 27.71 & 33.25 & 15.01 & 21.04 & 15.86 & 17.79 & 33.16\end{array}$ 
Table c-1 (Contd.)

\begin{tabular}{|c|c|c|c|c|c|c|c|c|}
\hline & 21 & 22 & 23 & 24 & 25 & 26 & 27 & 28 \\
\hline $\mathrm{SiO}_{2}$ & $47 \cdot 20$ & 47.63 & $47 \cdot 13$ & $47 \cdot 25$ & $48 \cdot 32$ & $47 \cdot 60$ & $46 \cdot 73$ & $46 \cdot 90$ \\
\hline $\mathrm{TiO}_{2}$ & 1.95 & 2.65 & $2 \cdot 43$ & $2 \cdot 55$ & $2 \cdot 45$ & 2.50 & $2 \cdot 51$ & $2 \cdot 76$ \\
\hline${ }_{2} \mathrm{O}_{3}$ & $12 \cdot 86$ & $14 \cdot 22$ & 13.61 & $14 \cdot 11$ & $14 \cdot 83$ & $14 \cdot 26$ & $13 \cdot 89$ & $15 \cdot 10$ \\
\hline${ }_{2} \mathrm{O}_{3}$ & 1.84 & $1 \cdot 34$ & 2.83 & 2.09 & $2 \cdot 97$ & $3 \cdot 12$ & $3 \cdot 37$ & 3.50 \\
\hline $\mathrm{FeO}$ & 9.83 & $9 \cdot 86$ & $9 \cdot 11$ & $9 \cdot 47$ & $9 \cdot 24$ & $8 \cdot 27$ & $8 \cdot 30$ & 8.75 \\
\hline $\mathrm{MnO}$ & $\cdot 19$ & $\cdot 19$ & $\cdot 20$ & $\cdot 26$ & .19 & $\cdot 19$ & $\cdot 18$ & $\cdot 22$ \\
\hline $\mathrm{MgO}$ & 10.92 & 6.65 & $8 \cdot 43$ & $6 \cdot 60$ & $5 \cdot 50$ & $6 \cdot 66$ & $6 \cdot 86$ & $5 \cdot 44$ \\
\hline $\mathrm{CaO}$ & $11 \cdot 24$ & 11.51 & $11 \cdot 72$ & $12 \cdot 02$ & $11 \cdot 42$ & $12 \cdot 20$ & 12.65 & $11 \cdot 18$ \\
\hline $\mathrm{Na} a_{2} \mathrm{O}$ & $2 \cdot 37$ & $3 \cdot 40$ & 3.07 & 3.17 & $3 \cdot 26$ & $3 \cdot 37$ & 3.04 & 3.54 \\
\hline $\mathrm{K}_{2} \mathrm{O}$ & .68 & $1 \cdot 35$ & $1 \cdot 26$ & $1 \cdot 22$ & $1 \cdot 39$ & $1 \cdot 28$ & $1 \cdot 22$ & $1 \cdot 45$ \\
\hline $\mathrm{P}_{2} \mathrm{O}_{5}$ & $\cdot 26$ & $\cdot 43$ & $\cdot 42$ & $\cdot 42$ & $\cdot 44$ & $\cdot 42$ & $\cdot 43$ & $\cdot 42$ \\
\hline $\mathrm{H}_{2} \mathrm{O}$ & .13 & $\cdot 32$ & .22 & .32 & $\cdot 24$ & .10 & .72 & $\cdot 15$ \\
\hline Total & $99 \cdot 47$ & 99.55 & $100 \cdot 43$ & $99 \cdot 48$ & $100 \cdot 26$ & 99.97 & $99 \cdot 90$ & $99 \cdot 41$ \\
\hline $\begin{array}{l}\text { Or } \\
A b \\
A n \\
\text { No } \\
D 1 \\
\text { Ol } \\
\text { Mt } \\
\text { Ilm } \\
\text { Ap } \\
\text { Rest }\end{array}$ & $\begin{array}{r}4 \cdot 04 \\
19 \cdot 36 \\
22 \cdot 59 \\
.45 \\
25 \cdot 77 \\
20.75 \\
2.69 \\
3.73 \\
.62 \\
.13\end{array}$ & $\begin{array}{r}8.04 \\
18.16 \\
19.70 \\
5.87 \\
28.73 \\
11.45 \\
1.96 \\
5.07 \\
1.03 \\
.32\end{array}$ & $\begin{array}{r}7 \cdot 43 \\
16 \cdot 45 \\
19 \cdot 59 \\
5 \cdot 13 \\
28 \cdot 91 \\
12 \cdot 80 \\
4 \cdot 09 \\
4 \cdot 60 \\
.99 \\
.22\end{array}$ & $\begin{array}{r}7.27 \\
17.90 \\
20.84 \\
4.96 \\
29.90 \\
10.20 \\
3.06 \\
4.88 \\
1.00 \\
.32\end{array}$ & $\begin{array}{r}8 \cdot 21 \\
22 \cdot 55 \\
21.72 \\
2.72 \\
26 \cdot 31 \\
8.50 \\
4.30 \\
4.65 \\
1.04 \\
.24\end{array}$ & $\begin{array}{r}7.57 \\
18.08 \\
20.01 \\
5.66 \\
30.67 \\
7.75 \\
4.53 \\
4.75 \\
1.00 \\
.10\end{array}$ & $\begin{array}{r}7.27 \\
16.35 \\
20.82 \\
5.19 \\
32.09 \\
7.53 \\
4.93 \\
4.81 \\
1.03 \\
.72\end{array}$ & $\begin{array}{r}8.63 \\
19.83 \\
21.18 \\
5.60 \\
26.07 \\
7.29 \\
5.11 \\
5.28 \\
1.00 \\
.15\end{array}$ \\
\hline $\begin{array}{l}\mathrm{Rb} \\
\mathrm{Cu} \\
\mathrm{Sr} \\
\mathrm{Ba} \\
\mathrm{Zn} \\
\mathrm{Zr} \\
\mathrm{Cr} \\
\mathrm{N} 1\end{array}$ & $\begin{array}{r}24 \\
108 \\
364 \\
300 \\
98 \\
160\end{array}$ & $\begin{array}{r}31 \\
115 \\
495 \\
432 \\
118 \\
240 \\
130 \\
118\end{array}$ & $\begin{array}{r}24 \\
101 \\
460 \\
500 \\
112 \\
219 \\
253 \\
190\end{array}$ & $\begin{array}{r}23 \\
123 \\
465 \\
365 \\
110 \\
235 \\
175 \\
103\end{array}$ & $\begin{array}{r}24 \\
65 \\
475 \\
370 \\
110 \\
240 \\
35 \\
55\end{array}$ & $\begin{array}{r}24 \\
83 \\
473 \\
440 \\
88 \\
230 \\
145 \\
94\end{array}$ & $\begin{array}{r}23 \\
146 \\
497 \\
382 \\
96 \\
222 \\
124 \\
104\end{array}$ & $\begin{array}{r}30 \\
77 \\
500 \\
450 \\
105 \\
240 \\
60 \\
48\end{array}$ \\
\hline . I. & 23.85 & $32 \cdot 06$ & 29.01 & $30 \cdot 12$ & $33 \cdot 48$ & $31 \cdot 31$ & 28.81 & $3 L$ \\
\hline
\end{tabular}


Table c-1 (conta)

\begin{tabular}{|c|c|c|c|c|c|c|c|}
\hline & 29 & 31 & 32 & * 39 & 40 & 41 & 45 \\
\hline $\mathrm{SIO}_{2}$ & $46 \cdot 50$ & $46 \cdot 76$ & $47 \cdot 70$ & $46 \cdot 10$ & $47 \cdot 77$ & $47 \cdot 37$ & $46 \cdot 25$ \\
\hline $\mathrm{PiO}_{2}$ & $2 \cdot 62$ & $1 \cdot 58$ & $2 \cdot 42$ & $2 \cdot 64$ & $2 \cdot 76$ & $1 \cdot 91$ & $2 \cdot 78$ \\
\hline $\mathrm{Al}_{2} \mathrm{O}_{3}$ & $14 \cdot 21$ & $9 \cdot 76$ & $14 \cdot 71$ & $14 \cdot 80$ & $14 \cdot 99$ & $11 \cdot 75$ & $14 \cdot 90$ \\
\hline $\mathrm{Fe}_{2} \mathrm{O}_{3}$ & $3 \cdot 11$ & $2 \cdot 46$ & $2 \cdot 33$ & $4 \cdot 45$ & $4 \cdot 36$ & $1 \cdot 88$ & $3 \cdot 25$ \\
\hline $\mathrm{FeO}$ & $9 \cdot 00$ & $8 \cdot 87$ & 9.53 & 8.07 & $8 \cdot 15$ & $9 \cdot 19$ & 8.89 \\
\hline Mno & $\cdot 48$ & $\cdot 19$ & $\cdot 20$ & $\cdot 26$ & $\cdot 24$ & $\cdot 18$ & $\cdot 23$ \\
\hline $\mathrm{MgO}$ & 6.02 & $15 \cdot 98$ & $6 \cdot 12$ & $5 \cdot 52$ & $5 \cdot 94$ & $11 \cdot 22$ & $5 \cdot 23$ \\
\hline $\mathrm{CaO}$ & $11 \cdot 80$ & 11.00 & $11 \cdot 32$ & $11 \cdot 30$ & 10.57 & 12.92 & $11 \cdot 33$ \\
\hline $\mathrm{Na}_{2} \mathrm{O}$ & $2 \cdot 64$ & 1.93 & $3 \cdot 32$ & $3 \cdot 10$ & 3.04 & $2 \cdot 58$ & $3 \cdot 46$ \\
\hline $\mathrm{K}_{2} \mathrm{O}$ & $1 \cdot 42$ & .61 & $1 \cdot 34$ & $1 \cdot 33$ & $1 \cdot 17$ & .83 & 1.54 \\
\hline $\mathrm{P}_{2} \mathrm{O}_{5}$ & $\cdot 39$ & .23 & $\cdot 47$ & $\cdot 37$ & $\cdot 39$ & $\cdot 30$ & $\cdot 43$ \\
\hline $\mathrm{H}_{2} \mathrm{O}$ & .55 & $\cdot 25$ & .25 & .77 & .76 & .13 & .52 \\
\hline Total & $98 \cdot 74$ & $99 \cdot 62$ & 99.55 & $98 \cdot 71$ & $100 \cdot 14$ & $100 \cdot 26$ & $98 \cdot 81$ \\
\hline $\begin{array}{l}\text { Or } \\
\mathrm{Ab} \\
\mathrm{An} \\
\mathrm{Ne} \\
\mathrm{D} 1 \\
\mathrm{Ol} \\
\mathrm{Mt} \\
\text { IIm } \\
\mathrm{Ap} \\
\text { Rest }\end{array}$ & $\begin{array}{r}8 \cdot 54 \\
18 \cdot 81 \\
23.14 \\
2.13 \\
27.70 \\
9 \cdot 07 \\
4.59 \\
5.07 \\
.94 \\
.55\end{array}$ & $\begin{array}{r}3.63 \\
15.60 \\
16.27 \\
.45 \\
29.69 \\
27.21 \\
3.59 \\
3.02 \\
.55 \\
.25\end{array}$ & $\begin{array}{r}7 \cdot 96 \\
20 \cdot 25 \\
21 \cdot 40 \\
4 \cdot 34 \\
26 \cdot 59 \\
10 \cdot 46 \\
3 \cdot 40 \\
4 \cdot 62 \\
.98 \\
.25\end{array}$ & $\begin{array}{r}8.06 \\
18.17 \\
23.12 \\
4.73 \\
26.34 \\
10.57 \\
2.97 \\
5.14 \\
.90 \\
.77\end{array}$ & $\begin{array}{r}6.97 \\
24 \cdot 79 \\
24.01 \\
.63 \\
21.59 \\
12.77 \\
2.92 \\
5.29 \\
.93 \\
\cdot 76\end{array}$ & $\begin{array}{r}4.90 \\
12.86 \\
18.00 \\
4.84 \\
35.55 \\
16.79 \\
2.72 \\
3.62 \\
.71 \\
.13\end{array}$ & $\begin{array}{r}9.26 \\
17.91 \\
20.93 \\
6.43 \\
27.34 \\
6.94 \\
4.79 \\
5.37 \\
1.04 \\
.52\end{array}$ \\
\hline $\begin{array}{l}\mathrm{Rb} \\
\mathrm{Cu} \\
\mathrm{Sr} \\
\mathrm{Ba} \\
\mathrm{Zn} \\
\mathrm{Zr} \\
\mathrm{Cr} \\
\mathrm{N} 1\end{array}$ & $\begin{array}{r}22 \\
90 \\
485 \\
450 \\
112 \\
220 \\
92 \\
91\end{array}$ & $\begin{array}{r}13 \\
103 \\
289 \\
218 \\
100 \\
125 \\
740 \\
444\end{array}$ & $\begin{array}{r}14 \\
83 \\
451 \\
432 \\
127 \\
228 \\
70 \\
76\end{array}$ & $\begin{array}{r}22 \\
101 \\
504 \\
410 \\
125 \\
230 \\
65 \\
81\end{array}$ & $\begin{array}{r}17 \\
43 \\
450 \\
460 \\
101 \\
224 \\
60 \\
53\end{array}$ & $\begin{array}{r}24 \\
116 \\
360 \\
370 \\
85 \\
168 \\
450 \\
176\end{array}$ & $\begin{array}{r}32 \\
90 \\
535 \\
460 \\
100 \\
240 \\
37 \\
53\end{array}$ \\
\hline D. I. & $29 \cdot 49$ & $19 \cdot 68$ & $32 \cdot 55$ & $32 \cdot 14$ & $32 \cdot 83$ & $22 \cdot 60$ & $33 \cdot 60$ \\
\hline
\end{tabular}


Table c-1 (contd.)

\begin{tabular}{|c|c|c|c|c|c|c|c|}
\hline & 46 & 47 & 48 & $* 101$ & *102 & 103 & 112 \\
\hline $\mathrm{SIO}_{2}$ & $46 \cdot 40$ & $47 \cdot 25$ & $47 \cdot 50$ & $47 \cdot 18$ & $47 \cdot 46$ & $47 \cdot 76$ & $47 \cdot 15$ \\
\hline $\mathrm{PiO}_{2}$ & $2 \cdot 57$ & $2 \cdot 70$ & $2 \cdot 52$ & $2 \cdot 44$ & 2.60 & $2 \cdot 79$ & $2 \cdot 48$ \\
\hline $\mathrm{Al}_{2} \mathrm{O}_{3}$ & $14 \cdot 20$ & $15 \cdot 34$ & $14 \cdot 98$ & 13.90 & $14 \cdot 45$ & $14 \cdot 80$ & $15 \cdot 06$ \\
\hline $\mathrm{Fe}_{2} \mathrm{O}_{3}$ & $2 \cdot 32$ & 3.02 & $2 \cdot 88$ & $7 \cdot 52$ & $3 \cdot 25$ & $2 \cdot 13$ & $2 \cdot 16$ \\
\hline $\mathrm{F} \otimes \mathrm{O}$ & $10 \cdot 04$ & $9 \cdot 59$ & 9.06 & $4 \cdot 51$ & $9 \cdot 53$ & $10 \cdot 28$ & $10 \cdot 11$ \\
\hline Mno & $\cdot 21$ & .23 & $\cdot 21$ & .18 & $\cdot 19$ & .19 & $\cdot 19$ \\
\hline $\mathrm{Mg} O$ & $6 \cdot 19$ & $5 \cdot 63$ & $5 \cdot 85$ & $6 \cdot 50$ & $5 \cdot 78$ & $5 \cdot 23$ & $5 \cdot 84$ \\
\hline $\mathrm{CaO}$ & 12.08 & $10 \cdot 97$ & $11 \cdot 45$ & 12.06 & $11 \cdot 49$ & $10 \cdot 83$ & $11 \cdot 75$ \\
\hline $\mathrm{Na}_{2} \mathrm{O}$ & $3 \cdot 24$ & $3 \cdot 40$ & 3.07 & $2 \cdot 81$ & $3 \cdot 54$ & $3 \cdot 39$ & $3 \cdot 27$ \\
\hline $\mathrm{K}_{2} \mathrm{O}$ & $1 \cdot 32$ & $1 \cdot 40$ & $1 \cdot 12$ & $1 \cdot 36$ & $1 \cdot 46$ & $1 \cdot 46$ & $1 \cdot 30$ \\
\hline $\mathrm{P}_{2} \mathrm{O}_{5}$ & .41 & $\cdot 46$ & $\cdot 33$ & $\cdot 43$ & $\cdot 48$ & .51 & $\cdot 47$ \\
\hline $\mathrm{H}_{2} \mathrm{O}$ & $\cdot 24$ & .63 & .30 & 1.19 & $\cdot 32$ & .35 & .29 \\
\hline Total & $99 \cdot 22$ & $100 \cdot 62$ & $99 \cdot 27$ & $100 \cdot 07$ & $100 \cdot 55$ & $99 \cdot 72$ & $99 \cdot 97$ \\
\hline $\begin{array}{l}O r \\
A b \\
A n \\
\text { Ne } \\
D 1 \\
\text { OI } \\
\text { Mt } \\
\text { IIm } \\
\text { Ap } \\
\text { Rest }\end{array}$ & $\begin{array}{r}7.88 \\
15.05 \\
20.51 \\
6.85 \\
30.68 \\
9.73 \\
3.40 \\
4.93 \\
.98 \\
.24\end{array}$ & $\begin{array}{r}8.27 \\
20.71 \\
22.46 \\
4.36 \\
23.77 \\
9.83 \\
4.38 \\
5.13 \\
1.09 \\
.63\end{array}$ & $\begin{array}{r}6.69 \\
22.57 \\
24.03 \\
1.99 \\
25.52 \\
9.36 \\
4.22 \\
4.83 \\
.79 \\
.30\end{array}$ & $\begin{array}{r}8.18 \\
18.17 \\
21.67 \\
3.26 \\
29.77 \\
10.26 \\
2.95 \\
4.71 \\
1.04 \\
1.19\end{array}$ & $\begin{array}{r}8.60 \\
17.66 \\
19.16 \\
6.60 \\
28.35 \\
10.25 \\
2.89 \\
5.28 \\
1.20 \\
.35\end{array}$ & $\begin{array}{r}8 \cdot 68 \\
22 \cdot 37 \\
20 \cdot 98 \\
3.51 \\
24.58 \\
10 \cdot 21 \\
3 \cdot 11 \\
5 \cdot 33 \\
1.22 \\
\cdot 35\end{array}$ & $\begin{array}{r}7.70 \\
17.89 \\
22.62 \\
5.33 \\
26.97 \\
10.52 \\
3.14 \\
4.72 \\
1.12 \\
.29\end{array}$ \\
\hline $\begin{array}{l}\mathrm{Rb} \\
\mathrm{Cu} \\
\mathrm{Sr} \\
\mathrm{Ba} \\
\mathrm{Zn} \\
\mathrm{Zr} \\
\mathrm{Cr} \\
\mathrm{N} \mathrm{I}\end{array}$ & $\begin{array}{r}20 \\
99 \\
437 \\
415 \\
109 \\
200 \\
83 \\
80\end{array}$ & $\begin{array}{c}27 \\
98 \\
517 \\
400 \\
120 \\
242 \\
49 \\
62\end{array}$ & $\begin{array}{r}21 \\
68 \\
443 \\
350 \\
114 \\
202 \\
83 \\
88\end{array}$ & $\begin{array}{r}38 \\
80 \\
550 \\
400 \\
104 \\
195 \\
60 \\
75\end{array}$ & $\begin{array}{r}30 \\
79 \\
568 \\
480 \\
81 \\
207 \\
45 \\
50\end{array}$ & $\begin{array}{r}35 \\
53 \\
540 \\
418 \\
113 \\
222\end{array}$ & $\begin{array}{r}35 \\
57 \\
515 \\
408 \\
102 \\
187\end{array}$ \\
\hline
\end{tabular}

D.I. $\begin{array}{lllllll}29.78 & 33.35 & 31.25 & 32 \cdot 16 & 33.47 & 34.57 & 30.92\end{array}$ 
Table C-1 (contd.)

\begin{tabular}{|c|c|c|c|c|c|c|c|}
\hline & 113 & 119 & 122 & 123 & 134 & 139 & 142 \\
\hline $\mathrm{SiO}_{2}$ & $47 \cdot 72$ & $47 \cdot 71$ & $48 \cdot 11$ & $47 \cdot 96$ & $47 \cdot 59$ & 48.08 & $46 \cdot 48$ \\
\hline $\mathrm{PlO}_{2}$ & $2 \cdot 70$ & 2.60 & 2.61 & $2 \cdot 52$ & $2 \cdot 17$ & 2.69 & 2.61 \\
\hline $\mathrm{Al}_{2} \mathrm{O}_{3}$ & 14.99 & $14 \cdot 83$ & $14 \cdot 54$ & $14 \cdot 37$ & $13 \cdot 27$ & $14 \cdot 15$ & $14 \cdot 18$ \\
\hline $\mathrm{Fe}_{2} \mathrm{O}_{3}$ & 2.59 & $2 \cdot 73$ & .85 & $2 \cdot 22$ & 3.00 & $3 \cdot 77$ & $1 \cdot 49$ \\
\hline $\mathrm{FeO}$ & 9.64 & $9 \cdot 79$ & 10.69 & 9.66 & $8 \cdot 26$ & 8.04 & 10.63 \\
\hline $\mathrm{MnO}$ & $\cdot 18$ & $\cdot 19$ & $\cdot 18$ & $\cdot 18$ & $\cdot 19$ & $\cdot 18$ & $\cdot 20$ \\
\hline $\mathrm{MgO}$ & $5 \cdot 49$ & $5 \cdot 75$ & $6 \cdot 16$ & $6 \cdot 33$ & $7 \cdot 83$ & $6 \cdot 47$ & 6.95 \\
\hline $\mathrm{CaO}$ & $11 \cdot 20$ & $11 \cdot 11$ & $11 \cdot 60$ & $12 \cdot 00$ & $13 \cdot 38$ & 11.55 & 11.04 \\
\hline $\mathrm{Na}_{2} \mathrm{O}$ & $3 \cdot 47$ & $3 \cdot 38$ & $3 \cdot 15$ & 3.05 & $2 \cdot 68$ & $3 \cdot 22$ & $2 \cdot 96$ \\
\hline $\mathrm{K}_{2} \mathrm{O}$ & $1 \cdot 39$ & $1 \cdot 47$ & $1 \cdot 26$ & $1 \cdot 30$ & 1.04 & $1 \cdot 40$ & $1 \cdot 38$ \\
\hline $\mathrm{P}_{2} \mathrm{O}_{5}$ & $\cdot 48$ & $\cdot 47$ & $\cdot 38$ & .45 & $\cdot 40$ & .52 & .52 \\
\hline $\mathrm{H}_{2} \mathrm{O}$ & .39 & .47 & .27 & .25 & $\cdot 47$ & .31 & $\cdot 34$ \\
\hline Total & $100 \cdot 24$ & $100 \cdot 50$ & $99 \cdot 79$ & $100 \cdot 70$ & $100 \cdot 28$ & $100 \cdot 38$ & $98 \cdot 78$ \\
\hline $\begin{array}{l}\mathrm{Or} \\
\mathrm{Ab} \\
\mathrm{An} \\
\mathrm{Ne} \\
\mathrm{Di} \\
\text { OI } \\
\mathrm{Mt} \\
\mathrm{IIm} \\
\mathrm{Ap} \\
\text { Rest }\end{array}$ & $\begin{array}{r}8 \cdot 22 \\
21 \cdot 19 \\
21 \cdot 25 \\
4 \cdot 45 \\
25 \cdot 70 \\
9 \cdot 16 \\
3 \cdot 76 \\
5 \cdot 13 \\
1 \cdot 14 \\
.39\end{array}$ & $\begin{array}{r}8.68 \\
20.58 \\
20.94 \\
4.34 \\
25.55 \\
9.91 \\
3.96 \\
4.94 \\
1.11 \\
.47\end{array}$ & $\begin{array}{r}7 \cdot 48 \\
19 \cdot 70 \\
21 \cdot 91 \\
3 \cdot 83 \\
27 \cdot 62 \\
12 \cdot 34 \\
1 \cdot 34 \\
4 \cdot 98 \\
.90 \\
\cdot 27\end{array}$ & $\begin{array}{r}7.68 \\
19.45 \\
21.66 \\
3.43 \\
28.62 \\
10.09 \\
3.22 \\
4.78 \\
1.06 \\
.25\end{array}$ & $\begin{array}{r}6 \cdot 16 \\
16 \cdot 36 \\
21 \cdot 14 \\
3 \cdot 44 \\
34 \cdot 57 \\
8 \cdot 89 \\
4 \cdot 36 \\
4 \cdot 13 \\
.95 \\
\cdot 47\end{array}$ & $\begin{array}{r}8.27 \\
22.48 \\
20.00 \\
2.57 \\
27.36 \\
7.53 \\
5.46 \\
5.10 \\
1.23 \\
.31\end{array}$ & $\begin{array}{r}8 \cdot 28 \\
17 \cdot 87 \\
21 \cdot 66 \\
4 \cdot 10 \\
25 \cdot 09 \\
14 \cdot 52 \\
2.19 \\
5.03 \\
1.25 \\
.34\end{array}$ \\
\hline $\begin{array}{l}\mathrm{Rb} \\
\mathrm{Cu} \\
\mathrm{Sr} \\
\mathrm{Ba} \\
\mathrm{Zn} \\
\mathrm{Zr} \\
\mathrm{Or}\end{array}$ & $\begin{array}{r}38 \\
81 \\
573 \\
490 \\
113 \\
223\end{array}$ & $\begin{array}{r}35 \\
57 \\
570 \\
510 \\
113 \\
208\end{array}$ & $\begin{array}{r}30 \\
73 \\
496 \\
418 \\
108 \\
221\end{array}$ & $\begin{array}{r}33 \\
82 \\
475 \\
422 \\
106 \\
198\end{array}$ & $\begin{array}{r}28 \\
140 \\
440 \\
395 \\
93 \\
160\end{array}$ & $\begin{array}{r}38 \\
85 \\
528 \\
460 \\
97 \\
229\end{array}$ & $\begin{array}{r}30 \\
68 \\
530 \\
460 \\
107 \\
213\end{array}$ \\
\hline
\end{tabular}

$\mathrm{Ni}$

D.I. $\quad \begin{array}{lllllll}33.86 & 33.60 & 31.01 & 30.56 & 25.96 & 33.31 & 30.25\end{array}$ 
Table $c-1$ (contd.)

\begin{tabular}{|c|c|c|c|c|c|c|c|c|}
\hline & 151 & 154 & 160 & 186 & 188 & 190 & 194 & 195 \\
\hline $\mathrm{SiO}_{2}$ & $46 \cdot 40$ & $47 \cdot 70$ & $47 \cdot 48$ & $48 \cdot 25$ & $48 \cdot 76$ & $47 \cdot 64$ & $46 \cdot 30$ & $46 \cdot 55$ \\
\hline $\mathrm{THO}_{2}$ & $1 \cdot 75$ & $2 \cdot 60$ & $2 \cdot 68$ & 2.06 & 2.68 & 2.66 & 1.84 & $1 \cdot 90$ \\
\hline $\mathrm{Al}_{2} \mathrm{O}_{3}$ & $10 \cdot 04$ & $14 \cdot 26$ & $14 \cdot 22$ & $12 \cdot 50$ & $15 \cdot 70$ & 13.61 & $10 \cdot 18$ & 10.08 \\
\hline $\mathrm{Fe}_{2} \mathrm{O}_{3}$ & 1.91 & $3 \cdot 22$ & 3.06 & 2.83 & 2.63 & $2 \cdot 31$ & $2 \cdot 76$ & $3 \cdot 41$ \\
\hline $\mathrm{FeO}$ & $9 \cdot 63$ & $9 \cdot 02$ & $8 \cdot 80$ & $7 \cdot 95$ & $8 \cdot 36$ & $9 \cdot 31$ & 8.63 & $\cdot 32$ \\
\hline Mno & $\cdot 19$ & .19 & $\cdot 18$ & $\cdot 17$ & .18 & $\cdot 18$ & .19 & \\
\hline MgO & $14 \cdot 82$ & $6 \cdot 87$ & $6 \cdot 49$ & $9 \cdot 16$ & $5 \cdot 21$ & $6 \cdot 75$ & 13.87 & $14 \cdot 02$ \\
\hline $\mathrm{CaO}$ & $11 \cdot 17$ & $11 \cdot 78$ & $11 \cdot 47$ & $13 \cdot 40$ & $10 \cdot 29$ & $11 \cdot 36$ & $12 \cdot 12$ & $12 \cdot 18$ \\
\hline $\mathrm{Na}_{2} \mathrm{O}$ & 2.50 & 3.03 & $3 \cdot 40$ & $2 \cdot 40$ & $3 \cdot 28$ & $3 \cdot 14$ & 1.86 & .06 \\
\hline $\mathrm{K}_{2} \mathrm{O}$ & $\cdot 78$ & $1 \cdot 21$ & $1 \cdot 38$ & .95 & 1.63 & $1 \cdot 33$ & .80 & 86 \\
\hline $\mathrm{P}_{2} \mathrm{O}_{5}$ & $\cdot 29$ & .39 & $\cdot 45$ & $\cdot 39$ & $\cdot 45$ & $\cdot 48$ & $\cdot 39$ & \\
\hline $\mathrm{H}_{2} \mathrm{O}$ & $\cdot 25$ & $\cdot 26$ & .24 & $\cdot 32$ & 73 & $\cdot 41$ & .66 & \\
\hline Total & $99 \cdot 73$ & $100 \cdot 46$ & $99 \cdot 85$ & $100 \cdot 38$ & $99 \cdot 86$ & $99 \cdot 18$ & $99 \cdot 60$ & - \\
\hline $\begin{array}{l}\text { Or } \\
\mathrm{Ab} \\
\mathrm{An} \\
\mathrm{Ne} \\
\mathrm{D} 1 \\
01 \\
\mathrm{Mt} \\
\mathrm{IIm} \\
\mathrm{Ap} \\
\text { Rest }\end{array}$ & $\begin{array}{r}4 \cdot 63 \\
12 \cdot 27 \\
13 \cdot 94 \\
4.87 \\
32.01 \\
25 \cdot 46 \\
2.78 \\
3.34 \\
.69 \\
.25\end{array}$ & $\begin{array}{r}7 \cdot 13 \\
20 \cdot 34 \\
21 \cdot 67 \\
2.83 \\
27 \cdot 70 \\
9 \cdot 83 \\
4.66 \\
4.92 \\
.92 \\
.26\end{array}$ & $\begin{array}{r}8.19 \\
19.73 \\
19.54 \\
4.95 \\
28.17 \\
8.79 \\
4.45 \\
5.11 \\
1.07 \\
.24\end{array}$ & $\begin{array}{r}5.61 \\
17.69 \\
20.51 \\
1.41 \\
34.91 \\
10.93 \\
4.10 \\
3.91 \\
.92 \\
.32\end{array}$ & $\begin{array}{r}9.71 \\
26.63 \\
23.49 \\
.73 \\
20.46 \\
8.93 \\
3.84 \\
5.13 \\
1.07 \\
.73\end{array}$ & $\begin{array}{r}7 \cdot 96 \\
21.18 \\
19.35 \\
3.10 \\
28.19 \\
10.58 \\
3.39 \\
5.11 \\
1.15 \\
.41\end{array}$ & $\begin{array}{r}4.78 \\
13.93 \\
17.25 \\
1.07 \\
32.77 \\
21.70 \\
4.04 \\
3.53 \\
.93 \\
.66\end{array}$ & $\begin{array}{r}13.05 \\
15.74 \\
2.38 \\
34.16 \\
20.31 \\
4.95 \\
3.61 \\
.71 \\
.44\end{array}$ \\
\hline $\begin{array}{l}\mathrm{Rb} \\
\mathrm{Cu} \\
\mathrm{Sr} \\
\mathrm{Ba} \\
\mathrm{Zn} \\
\mathrm{Zr} \\
\mathrm{Cr} \\
\mathrm{Ni}\end{array}$ & $\begin{array}{r}20 \\
108 \\
335 \\
300 \\
98 \\
137\end{array}$ & $\begin{array}{r}33 \\
128 \\
498 \\
440 \\
103 \\
210 \\
110 \\
98\end{array}$ & $\begin{array}{r}38 \\
88 \\
545 \\
470 \\
90 \\
221 \\
150 \\
98\end{array}$ & $\begin{array}{r}25 \\
91 \\
398 \\
350 \\
86 \\
152 \\
575 \\
170\end{array}$ & $\begin{array}{r}37 \\
60 \\
600 \\
600 \\
93 \\
252 \\
75 \\
50\end{array}$ & $\begin{array}{r}28 \\
87 \\
520 \\
395 \\
88 \\
233\end{array}$ & $\begin{array}{r}20 \\
88 \\
360 \\
350 \\
83 \\
148\end{array}$ & $\begin{array}{r}20 \\
91 \\
382 \\
278 \\
90 \\
136\end{array}$ \\
\hline
\end{tabular}

D.I. $\quad 21 \cdot 78 \quad 30 \cdot 30 \quad 32 \cdot 87 \quad 24 \cdot 71 \quad 37 \cdot 07 \quad 32 \cdot 23 \quad 19 \cdot 78 \quad 20 \cdot 52$ 


\section{Table $C-2$}

Chemical Analyses of Lavas from La Grille

\begin{tabular}{|c|c|c|c|c|c|c|c|}
\hline & 9 & 10 & 36 & $37(2)$ & $37(3)$ & 52 & 53 \\
\hline $\mathrm{SiO}_{2}$ & $43 \cdot 49$ & 43.61 & $42 \cdot 70$ & $43 \cdot 16$ & $43 \cdot 33$ & $43 \cdot 50$ & $44 \cdot 92$ \\
\hline $\mathrm{LO}_{2}$ & $2 \cdot 13$ & 2.04 & 1.92 & $1 \cdot 72$ & $1 \cdot 74$ & $2 \cdot 20$ & $1 \cdot 75$ \\
\hline $\mathrm{Al}_{2} \mathrm{O}_{3}$ & $12 \cdot 66$ & $12 \cdot 64$ & $9 \cdot 95$ & $10 \cdot 36$ & $10 \cdot 44$ & 12.09 & $12 \cdot 98$ \\
\hline $\mathrm{Fe}_{2} \mathrm{O}_{3}$ & $2 \cdot 06$ & .55 & $2 \cdot 86$ & 2.99 & 3.23 & $3 \cdot 47$ & $3 \cdot 43$ \\
\hline $\mathrm{FeO}$ & $9 \cdot 45$ & $10 \cdot 86$ & 8.67 & $8 \cdot 16$ & $8 \cdot 26$ & $7 \cdot 80$ & 8.56 \\
\hline Mno & .23 & $\cdot 20$ & $\cdot 28$ & $\cdot 19$ & $\cdot 20$ & $\cdot 20$ & $\cdot 21$ \\
\hline $\mathrm{MgO}$ & $12 \cdot 68$ & $12 \cdot 24$ & $16 \cdot 70$ & $17 \cdot 36$ & $17 \cdot 19$ & $12 \cdot 26$ & $12 \cdot 25$ \\
\hline $\mathrm{CaO}$ & $12 \cdot 44$ & 12.03 & $11 \cdot 79$ & $11 \cdot 31$ & 11.57 & $12 \cdot 22$ & $11 \cdot 17$ \\
\hline $\mathrm{Na}_{2} \mathrm{O}$ & 3.08 & 2.91 & $2 \cdot 37$ & $2 \cdot 47$ & $2 \cdot 35$ & $3 \cdot 26$ & $3 \cdot 24$ \\
\hline $\mathrm{K}_{2} \mathrm{O}$ & $1 \cdot 32$ & 1.05 & $1 \cdot 30$ & $1 \cdot 18$ & $1 \cdot 16$ & $1 \cdot 34$ & $\cdot 74$ \\
\hline $\mathrm{P}_{2} \mathrm{O}_{5}$ & $\cdot 48$ & $\cdot 45$ & .61 & $\cdot 47$ & $\cdot 46$ & .64 & $\cdot 46$ \\
\hline $\mathrm{H}_{2} \mathrm{O}^{-}$ & $\cdot 30$ & $\cdot 48$ & 1.08 & .41 & .42 & 1.13 & .51 \\
\hline Total & $100 \cdot 32$ & 99.08 & $100 \cdot 23$ & $99 \cdot 78$ & $100 \cdot 34$ & 100.05 & $100 \cdot 22$ \\
\hline $\begin{array}{l}\text { Or } \\
\mathrm{Ab} \\
\mathrm{An} \\
\mathrm{Ne} \\
\mathrm{Lc} \\
\mathrm{DI} \\
\mathrm{OI} \\
\mathrm{Mt} \\
\mathrm{IIm} \\
\mathrm{Ap} \\
\text { Rest }\end{array}$ & $\begin{array}{r}4 \cdot 84 \\
- \\
16 \cdot 81 \\
14 \cdot 11 \\
2 \cdot 32 \\
33 \cdot 59 \\
20 \cdot 16 \\
2.99 \\
4 \cdot 04 \\
1 \cdot 14 \\
\cdot 30\end{array}$ & $\begin{array}{r}6.29 \\
1.57 \\
18.59 \\
12.68 \\
- \\
31.62 \\
23.44 \\
.81 \\
3.93 \\
1.08 \\
.48\end{array}$ & $\begin{array}{r}3.88 \\
- \\
12.78 \\
10.95 \\
3.03 \\
33.63 \\
26.41 \\
4.18 \\
3.68 \\
1.46 \\
1.08\end{array}$ & $\begin{array}{r}6.88 \\
- \\
13 \cdot 78 \\
11 \cdot 39 \\
\cdot 10 \\
31 \cdot 49 \\
27 \cdot 59 \\
4 \cdot 36 \\
3.29 \\
1 \cdot 12 \\
\cdot 41\end{array}$ & $\begin{array}{r}6 \cdot 86 \\
\cdot 12 \\
14 \cdot 52 \\
10 \cdot 71 \\
- \\
31 \cdot 74 \\
26 \cdot 96 \\
4 \cdot 69 \\
3.31 \\
1.09 \\
.41\end{array}$ & $\begin{array}{r}8.00 \\
2.63 \\
14.55 \\
13.67 \\
- \\
33.90 \\
16.49 \\
5.00 \\
4.22 \\
1.53 \\
1.13\end{array}$ & $\begin{array}{r}4 \cdot 38 \\
11 \cdot 62 \\
18 \cdot 74 \\
8.59 \\
- \\
27 \cdot 11 \\
20 \cdot 14 \\
4.99 \\
3.33 \\
1.09 \\
.51\end{array}$ \\
\hline $\begin{array}{l}\mathrm{Rb} \\
\mathrm{Cu} \\
\mathrm{Sr} \\
\mathrm{Ba} \\
\mathrm{Zn} \\
\mathrm{Zr} \\
\mathrm{Cr} \\
\mathrm{Ni}\end{array}$ & $\begin{array}{r}30 \\
75 \\
600 \\
710 \\
80 \\
217\end{array}$ & $\begin{array}{r}26 \\
83 \\
530 \\
530 \\
89 \\
155\end{array}$ & $\begin{array}{r}32 \\
89 \\
590 \\
625 \\
105 \\
202 \\
650 \\
540\end{array}$ & $\begin{array}{r}33 \\
81 \\
525 \\
670 \\
85 \\
152 \\
910 \\
2430\end{array}$ & $\begin{array}{r}25 \\
81 \\
526 \\
620 \\
71 \\
158 \\
820 \\
525\end{array}$ & $\begin{array}{r}55 \\
80 \\
690 \\
850 \\
87 \\
197 \\
590 \\
310\end{array}$ & $\begin{array}{r}39 \\
83 \\
645 \\
794 \\
85 \\
234\end{array}$ \\
\hline
\end{tabular}

D.I. $\quad \begin{array}{lllllll}21.27 & 20 \cdot 54 & 17 \cdot 86 & 18 \cdot 38 & 17 \cdot 69 & 24 \cdot 31 & 24 \cdot 60\end{array}$ 
Table C-2 (Contd.)

\begin{tabular}{|c|c|c|c|c|c|c|}
\hline & 54 & 55 & 56 & 57 & 58 & 59 \\
\hline $\mathrm{SiO}_{2}$ & $42 \cdot 04$ & $44 \cdot 91$ & $41 \cdot 41$ & $46 \cdot 59$ & $42 \cdot 73$ & $43 \cdot 26$ \\
\hline $\mathrm{TiO}_{2}$ & 1.67 & 1.73 & $2 \cdot 18$ & $1 \cdot 72$ & $2 \cdot 17$ & $2 \cdot 30$ \\
\hline $\mathrm{Al}_{2} \mathrm{O}_{3}$ & 9.06 & $12 \cdot 75$ & $11 \cdot 87$ & $14 \cdot 00$ & $12 \cdot 81$ & 13.56 \\
\hline $\mathrm{Fe}_{2} \mathrm{O}_{3}$ & $3 \cdot 46$ & 1.81 & 3.79 & $2 \cdot 33$ & 3.93 & $2 \cdot 34$ \\
\hline $\mathrm{FeO}$ & $7 \cdot 58$ & $10 \cdot 47$ & $8 \cdot 42$ & 10.01 & $8 \cdot 17$ & $9 \cdot 14$ \\
\hline MnO & .20 & .21 & $\cdot 20$ & $\cdot 21$ & .23 & $\cdot 20$ \\
\hline MgO & $20 \cdot 01$ & $12 \cdot 00$ & $12 \cdot 81$ & $9 \cdot 48$ & $10 \cdot 96$ & $9 \cdot 74$ \\
\hline $\mathrm{CaO}$ & $10 \cdot 85$ & $11 \cdot 14$ & 13.06 & 11.08 & $12 \cdot 01$ & $12 \cdot 76$ \\
\hline $\mathrm{Na}_{2} \mathrm{O}$ & 1.88 & 2.68 & $2 \cdot 73$ & $2 \cdot 81$ & 3.62 & 2.54 \\
\hline $\mathrm{K}_{2} \mathrm{O}$ & .93 & $\cdot 76$ & $1 \cdot 36$ & .55 & $1 \cdot 49$ & $1 \cdot 29$ \\
\hline $\mathrm{P}_{2} \mathrm{O}_{5}$ & .55 & $\cdot 41$ & .84 & .29 & .65 & .51 \\
\hline $\mathrm{H}_{2} \mathrm{O}$ & .60 & .52 & 1.11 & .68 & .35 & $1 \cdot 37$ \\
\hline Total & 98.83 & $99 \cdot 39$ & $99 \cdot 78$ & $99 \cdot 75$ & $99 \cdot 18$ & 99.01 \\
\hline $\begin{array}{l}\text { Or } \\
\text { Ab } \\
\text { An } \\
\text { Ne } \\
\text { Lo } \\
\text { Di } \\
\text { O1 } \\
\text { Mt } \\
\text { Ilm } \\
\text { Ap } \\
\text { Rest }\end{array}$ & $\begin{array}{r}5 \cdot 59 \\
.47 \\
13.78 \\
8.52 \\
- \\
29 \cdot 57 \\
32.41 \\
5.11 \\
3.23 \\
1.33 \\
.60\end{array}$ & $\begin{array}{r}4.54 \\
11.33 \\
20.75 \\
6.29 \\
- \\
25.28 \\
23.86 \\
2.65 \\
3.32 \\
.98 \\
.52\end{array}$ & $\begin{array}{r}.34 \\
-3.33 \\
16.60 \\
6.12 \\
34.94 \\
17.82 \\
5.57 \\
4.19 \\
2.02 \\
1.11\end{array}$ & $\begin{array}{r}3 \cdot 28 \\
19 \cdot 82 \\
24 \cdot 18 \\
2.26 \\
-.91 \\
23 \cdot 91 \\
19 \cdot 15 \\
3 \cdot 41 \\
3.30 \\
.69 \\
.68\end{array}$ & $\begin{array}{r}8.91 \\
1.03 \\
14.47 \\
16.22 \\
- \\
33.22 \\
14.66 \\
5.76 \\
4.17 \\
1.56 \\
.35\end{array}$ & $\begin{array}{r}7 \cdot 81 \\
3 \cdot 92 \\
22 \cdot 31 \\
9 \cdot 80 \\
- \\
31 \cdot 60 \\
15 \cdot 38 \\
3 \cdot 47 \\
4 \cdot 47 \\
1 \cdot 24 \\
1.37\end{array}$ \\
\hline $\begin{array}{l}\mathrm{Rb} \\
\mathrm{Cu} \\
\mathrm{Sr} \\
\mathrm{Ba} \\
\mathrm{Zn} \\
\mathrm{Zr}\end{array}$ & $\begin{array}{r}26 \\
80 \\
495 \\
525 \\
90 \\
157\end{array}$ & $\begin{array}{r}13 \\
78 \\
480 \\
475 \\
100 \\
130\end{array}$ & $\begin{array}{r}37 \\
69 \\
590 \\
720 \\
100 \\
242\end{array}$ & $\begin{array}{r}14 \\
60 \\
331 \\
350 \\
105 \\
145\end{array}$ & $\begin{array}{r}50 \\
70 \\
700 \\
880 \\
87 \\
245\end{array}$ & $\begin{array}{r}25 \\
77 \\
625 \\
700 \\
85 \\
216\end{array}$ \\
\hline D. I. & 14.58 & $22 \cdot 15$ & $19 \cdot 13$ & $25 \cdot 36$ & $26 \cdot 17$ & 21.52 \\
\hline
\end{tabular}


Table c-2 (Conta.)

\begin{tabular}{|c|c|c|c|c|c|c|}
\hline & 165 & 171 & 172 & 173 & 178 & 192 \\
\hline $\mathrm{SiO}_{2}$ & 42.03 & $41 \cdot 97$ & $42 \cdot 80$ & $42 \cdot 82$ & $41 \cdot 72$ & $43 \cdot 14$ \\
\hline $\mathrm{TiO}_{2}$ & 1.98 & $2 \cdot 16$ & $2 \cdot 11$ & $2 \cdot 04$ & $2 \cdot 22$ & $2 \cdot 30$ \\
\hline $\mathrm{Al}_{2} \mathrm{O}_{3}$ & $11 \cdot 76$ & $10 \cdot 88$ & $12 \cdot 10$ & $11 \cdot 47$ & $12 \cdot 69$ & $13 \cdot 35$ \\
\hline $\mathrm{Fe}_{2} \mathrm{O}_{3}$ & $4 \cdot 53$ & $3 \cdot 25$ & 3.57 & $2 \cdot 62$ & $3 \cdot 40$ & $3 \cdot 92$ \\
\hline $\mathrm{FeO}$ & $7 \cdot 28$ & $8 \cdot 76$ & 8.07 & $8 \cdot 82$ & 9.07 & $8 \cdot 20$ \\
\hline Mno & $\cdot 20$ & $\cdot 21$ & $\cdot 20$ & $\cdot 21$ & $\cdot 21$ & $\cdot 22$ \\
\hline $\mathrm{MgO}$ & $14 \cdot 42$ & $14 \cdot 22$ & $12 \cdot 44$ & $14 \cdot 21$ & $10 \cdot 92$ & $10 \cdot 36$ \\
\hline $\mathrm{CaO}$ & $12 \cdot 24$ & $12 \cdot 45$ & $12 \cdot 67$ & $12 \cdot 23$ & 13.53 & $11 \cdot 11$ \\
\hline $\mathrm{Na}_{2} \mathrm{O}$ & $2 \cdot 23$ & 3.08 & 2.95 & $2 \cdot 89$ & 3.03 & $4 \cdot 27$ \\
\hline $\mathrm{K}_{2} \mathrm{O}$ & $\cdot 44$ & $1 \cdot 14$ & $1 \cdot 44$ & 1.03 & $1 \cdot 15$ & $1 \cdot 74$ \\
\hline $\mathrm{P}_{2} \mathrm{O}_{5}$ & .64 & .64 & .53 & .58 & $\cdot 80$ & .67 \\
\hline $\mathrm{H}_{2} \mathrm{O}$ & $2 \cdot 30$ & .53 & .64 & $\cdot 34$ & $1 \cdot 31$ & .51 \\
\hline Total & 100.05 & $99 \cdot 29$ & $99 \cdot 51$ & $99 \cdot 26$ & $100 \cdot 01$ & $99 \cdot 79$ \\
\hline $\begin{array}{l}\text { Or } \\
\mathrm{Ab} \\
\mathrm{An} \\
\mathrm{Ne} \\
\mathrm{Lc} \\
\mathrm{D} 1 \\
\mathrm{OI} \\
\mathrm{Mt} \\
\mathrm{IIn} \\
\mathrm{Ap} \\
\text { Rest }\end{array}$ & $\begin{array}{r}2 \cdot 66 \\
7 \cdot 10 \\
21 \cdot 25 \\
6 \cdot 61 \\
- \\
28 \cdot 99 \\
21 \cdot 28 \\
6 \cdot 72 \\
3 \cdot 85 \\
1 \cdot 55 \\
2 \cdot 30\end{array}$ & $\begin{array}{r}\cdot 74 \\
- \\
12 \cdot 65 \\
14 \cdot 29 \\
4 \cdot 77 \\
36 \cdot 46 \\
20 \cdot 64 \\
4 \cdot 77 \\
4 \cdot 15 \\
1.53 \\
.53\end{array}$ & $\begin{array}{r}5.72 \\
- \\
15.69 \\
13.67 \\
2.26 \\
35.42 \\
16.68 \\
5.23 \\
4.05 \\
1.27 \\
.64\end{array}$ & $\begin{array}{r}6 \cdot 15 \\
\cdot 19 \\
15 \cdot 45 \\
13 \cdot 28 \\
- \\
33 \cdot 65 \\
22 \cdot 14 \\
3 \cdot 84 \\
3 \cdot 92 \\
1 \cdot 39 \\
\cdot 34\end{array}$ & $\begin{array}{r}1.91 \\
- \\
17.85 \\
14.06 \\
3.90 \\
36.05 \\
15.06 \\
4.99 \\
4.27 \\
1.92 \\
1.31\end{array}$ & $\begin{array}{r}10 \cdot 35 \\
1 \cdot 78 \\
12 \cdot 21 \\
18 \cdot 74 \\
- \\
31 \cdot 15 \\
14 \cdot 05 \\
5 \cdot 72 \\
4 \cdot 40 \\
1.60 \\
.51\end{array}$ \\
\hline $\begin{array}{l}\mathrm{Rb} \\
\mathrm{Cu} \\
\mathrm{Sr} \\
\mathrm{Ba} \\
\mathrm{Zn} \\
\mathrm{Zr} \\
\mathrm{Cr} \\
\mathrm{N} 1\end{array}$ & $\begin{array}{r}101 \\
72 \\
655 \\
900 \\
80 \\
152\end{array}$ & $\begin{array}{r}35 \\
71 \\
635 \\
720 \\
88 \\
174\end{array}$ & $\begin{array}{r}47 \\
80 \\
6115 \\
850 \\
84 \\
176 \\
600 \\
290\end{array}$ & $\begin{array}{r}44 \\
80 \\
600 \\
680 \\
92 \\
173\end{array}$ & $\begin{array}{r}58 \\
79 \\
792 \\
900 \\
92 \\
207\end{array}$ & $\begin{array}{r}79 \\
77 \\
762 \\
850 \\
112 \\
200\end{array}$ \\
\hline D.I. & $16 \cdot 37$ & $19 \cdot 80$ & $21 \cdot 65$ & 19.63 & $19 \cdot 87$ & $30 \cdot 88$ \\
\hline
\end{tabular}




\section{Table $\mathrm{C}-3$}

Analyses of rooks other than lava flows from Kartala and La Grille

Badjini lavas

\begin{tabular}{|c|c|c|c|c|c|}
\hline & & & & & \\
\hline & 132 & 146 & 147 & 156 & 158 \\
\hline $\mathrm{SiO}_{2}$ & $48 \cdot 61$ & $47 \cdot 10$ & $46 \cdot 80$ & $45 \cdot 86$ & $46 \cdot 58$ \\
\hline $\mathrm{THO}_{2}$ & $2 \cdot 78$ & $2 \cdot 56$ & $2 \cdot 48$ & $2 \cdot 60$ & 2.51 \\
\hline $\mathrm{Al}_{2} \mathrm{O}_{3}$ & $15 \cdot 32$ & $14 \cdot 05$ & $14 \cdot 12$ & $12 \cdot 81$ & 14.02 \\
\hline $\mathrm{Fe}_{2} \mathrm{O}_{3}$ & $5 \cdot 03$ & $3 \cdot 38$ & $1 \cdot 76$ & $5 \cdot 57$ & $5 \cdot 77$ \\
\hline $\mathrm{FeO}$ & $7 \cdot 29$ & 9.04 & $9 \cdot 78$ & 6.91 & $7 \cdot 19$ \\
\hline Mno & $\cdot 19$ & $\cdot 19$ & $\cdot 48$ & $\cdot 17$ & $\cdot 19$ \\
\hline $\mathrm{MgO}$ & 5.09 & $6 \cdot 60$ & $5 \cdot 64$ & 9.95 & 8.02 \\
\hline $\mathrm{CaO}$ & $10 \cdot 42$ & $12 \cdot 58$ & $11 \cdot 20$ & $11 \cdot 47$ & 10.86 \\
\hline $\mathrm{Na}_{2} \mathrm{O}$ & $3 \cdot 41$ & $2 \cdot 66$ & $4 \cdot 36$ & $2 \cdot 26$ & $2 \cdot 52$ \\
\hline $\mathrm{K}_{2} \mathrm{O}$ & 1.55 & $1 \cdot 12$ & .85 & $1 \cdot 14$ & $1 \cdot 17$ \\
\hline $\mathrm{P}_{2} \mathrm{O}_{5}$ & .54 & $\cdot 42$ & $\cdot 38$ & $\cdot 46$ & $\cdot 40$ \\
\hline $\mathrm{H}_{2} \mathrm{O}$ & .51 & .70 & .66 & 1.13 & 1.07 \\
\hline Total & $100 \cdot 74$ & $100 \cdot 40$ & 98.51 & $100 \cdot 33$ & $100 \cdot 30$ \\
\hline $\begin{array}{l}\text { Or } \\
\text { Ab } \\
\text { An } \\
\text { No } \\
\text { Di } \\
\text { OI } \\
\text { Mt } \\
\text { Ilm } \\
\text { Ap } \\
\text { Rest }\end{array}$ & $\begin{array}{r}9.14 \\
28.65 \\
21.86 \\
.07 \\
21.07 \\
5.40 \\
7.27 \\
5.27 \\
1.28 \\
.51\end{array}$ & $\begin{array}{r}6.64 \\
18.93 \\
23.15 \\
1.97 \\
29.86 \\
8.66 \\
4.91 \\
4.88 \\
1.00 \\
.70\end{array}$ & $\begin{array}{r}5.13 \\
19.81 \\
16.80 \\
9.69 \\
30.92 \\
9.31 \\
2.61 \\
4.81 \\
.92 \\
.66\end{array}$ & $\begin{array}{r}6.85 \\
15.91 \\
21.79 \\
1.91 \\
26.69 \\
17.77 \\
2.95 \\
5.02 \\
1.11 \\
1.13\end{array}$ & $\begin{array}{r}7.00 \\
19.70 \\
23.76 \\
1.02 \\
22.98 \\
16.83 \\
2.93 \\
4.82 \\
.96 \\
1.07\end{array}$ \\
\hline $\begin{array}{l}\mathrm{Rb} \\
\mathrm{Cu} \\
\mathrm{Sr} \\
\mathrm{Ba} \\
\mathrm{Zn} \\
\mathrm{Zr} \\
\mathrm{Cr} \\
\mathrm{N} 1\end{array}$ & $\begin{array}{r}38 \\
54 \\
600 \\
490 \\
103 \\
230\end{array}$ & $\begin{array}{r}25 \\
93 \\
545 \\
420 \\
82 \\
187\end{array}$ & $\begin{array}{r}16 \\
92 \\
435 \\
350 \\
107 \\
175\end{array}$ & $\begin{array}{r}24 \\
82 \\
497 \\
625 \\
82 \\
173 \\
480 \\
210\end{array}$ & $\begin{array}{r}17 \\
68 \\
540 \\
590 \\
95 \\
214\end{array}$ \\
\hline D. I. & $37 \cdot 86$ & $27 \cdot 54$ & $34 \cdot 63$ & $26 \cdot 06$ & $28 \cdot 45$ \\
\hline
\end{tabular}


Table C-4

Analyses of rooks other than lava flows from Kartala and La Grille

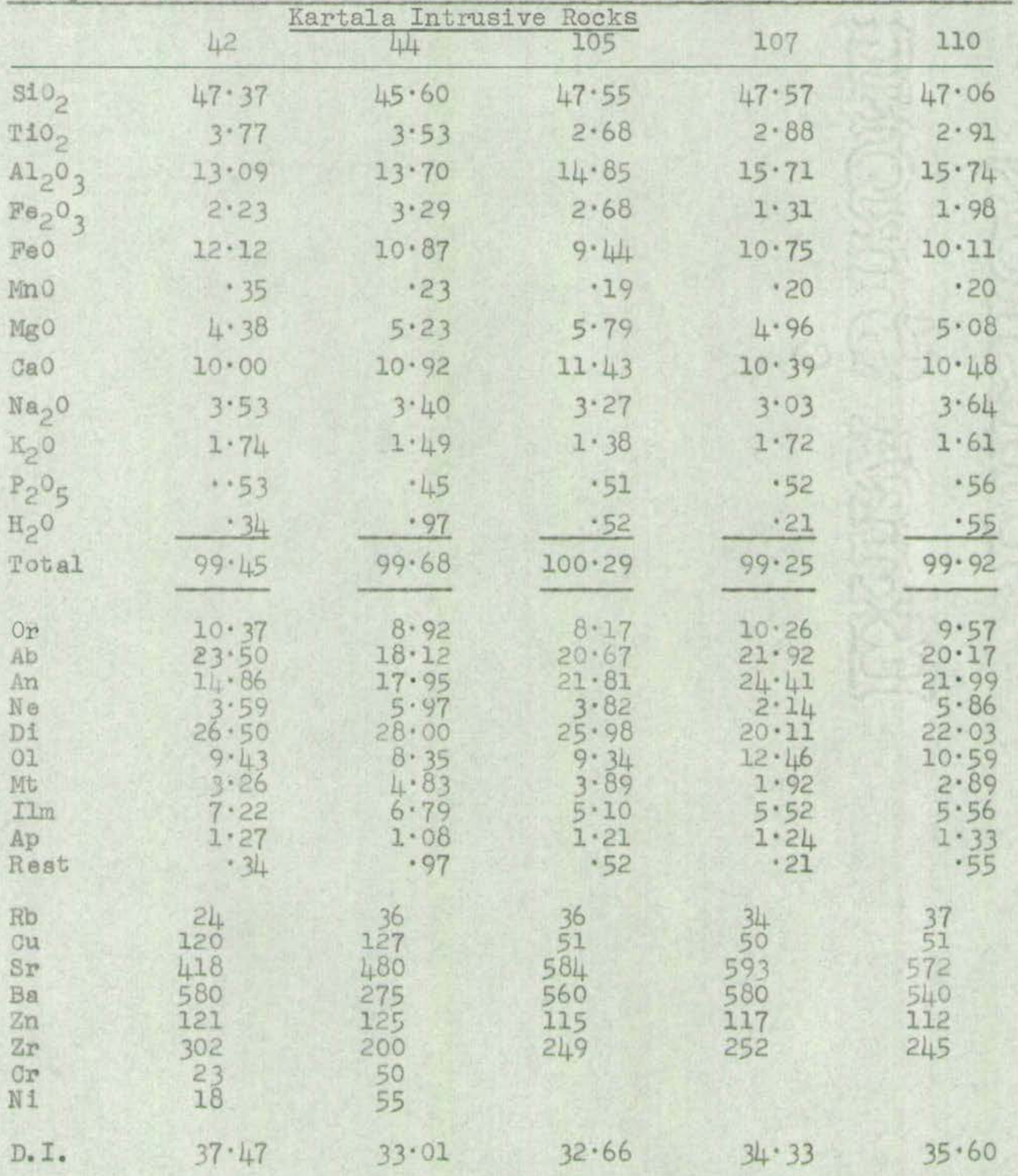


Table c-5

Analyses of rooks other than lava flows from Kartale and La Grille Miscellaneous Analysed Rocks

\begin{tabular}{|c|c|c|c|c|c|c|c|}
\hline & & 16 & 30 & 35 & $38 \mathrm{~A}$ & 130 & Mo-125 \\
\hline $\mathrm{SiO}_{2}$ & & $40 \cdot 55$ & $46 \cdot 94$ & $41 \cdot 78$ & $43 \cdot 72$ & $48 \cdot 73$ & \\
\hline $\mathrm{T}^{1} \mathrm{O}_{2}$ & & $1 \cdot 71$ & 2.60 & .08 & 1.63 & $2 \cdot 11$ & \\
\hline $\mathrm{Al}_{2} \mathrm{O}_{3}$ & & $8 \cdot 57$ & $14 \cdot 40$ & .95 & $11 \cdot 86$ & 13.95 & \\
\hline $\mathrm{Fe}_{2} \mathrm{O}_{3}$ & & $5 \cdot 32$ & $2 \cdot 42$ & .05 & & 2.93 & \\
\hline $\mathrm{FeO}$ & & $7 \cdot 44$ & $9 \cdot 50$ & $9 \cdot 02$ & $8 \cdot 29$ & $9 \cdot 08$ & \\
\hline MnO & & .21 & $\cdot 21$ & .20 & $\cdot 20$ & $\cdot 18$ & \\
\hline $\mathrm{MgO}$ & & $19 \cdot 22$ & $7 \cdot 23$ & $44 \cdot 70$ & $12 \cdot 64$ & $8 \cdot 61$ & \\
\hline $\mathrm{CaO}$ & & 8.65 & $9 \cdot 85$ & $1 \cdot 80$ & $12 \cdot 14$ & 10.54 & \\
\hline $\mathrm{Na}_{2} \mathrm{O}$ & & $\cdot 88$ & $3 \cdot 58$ & $\cdot 20$ & $1 \cdot 72$ & $2 \cdot 90$ & \\
\hline $\mathrm{K}_{2} \mathrm{O}$ & & .09 & $1 \cdot 36$ & .01 & .66 & .68 & \\
\hline $\mathrm{P}_{2} \mathrm{O}_{5}$ & & 51 & .69 & .02 & $\cdot 43$ & $\cdot 34$ & \\
\hline $\mathrm{H}_{2} \mathrm{O}$ & & $5 \cdot 93$ & .69 & .19 & $2 \cdot 44$ & .27 & \\
\hline Total & & 99.08 & $99 \cdot 47$ & 99.00 & $99 \cdot 53$ & $100 \cdot 32$ & \\
\hline $\begin{array}{l}\text { Or } \\
\mathrm{Ab} \\
\mathrm{An} \\
\mathrm{Ne} \\
\mathrm{D} 1 \\
\mathrm{Ol} \\
\mathrm{Mt} \\
\mathrm{Ilm} \\
\mathrm{Ap} \\
\text { Rest }\end{array}$ & Hy & $\begin{array}{r}.57 \\
7.99 \\
20.57 \\
-7 \\
17.30 \\
15.95 \\
24.56 \\
8.28 \\
3.49 \\
1.30 \\
5.93\end{array}$ & $\begin{array}{r}8 \cdot 13 \\
22 \cdot 81 \\
19 \cdot 44 \\
4 \cdot 25 \\
20.76 \\
- \\
14 \cdot 40 \\
3.55 \\
5.00 \\
1.65 \\
.69\end{array}$ & $\begin{array}{r}.06 \\
1.71 \\
1.68 \\
- \\
5.70 \\
1.47 \\
89.09 \\
.07 \\
.15 \\
.05 \\
.19\end{array}$ & $\begin{array}{r}4.02 \\
11.60 \\
23.37 \\
1.83 \\
28.61 \\
- \\
20.66 \\
5.67 \\
3.19 \\
1.05 \\
2.44\end{array}$ & $\begin{array}{r}4 \cdot 02 \\
24 \cdot 52 \\
23 \cdot 02 \\
- \\
21 \cdot 89 \\
5 \cdot 83 \\
11 \cdot 66 \\
4 \cdot 25 \\
4 \cdot 00 \\
.80 \\
\cdot 27\end{array}$ & \\
\hline $\begin{array}{l}\mathrm{Rb} \\
\mathrm{Cu} \\
\mathrm{Sr} \\
\mathrm{Ba} \\
\mathrm{Zn} \\
\mathrm{Zr} \\
\mathrm{Cr} \\
\mathrm{Ni}\end{array}$ & & $\begin{array}{r}<5 \\
80 \\
84 \\
140 \\
85 \\
127\end{array}$ & $\begin{array}{r}42 \\
57 \\
846 \\
870 \\
125 \\
347 \\
123 \\
94\end{array}$ & $\begin{array}{l}<5 \\
30 \\
20 \\
<5 \\
97 \\
20\end{array}$ & $\begin{array}{r}17 \\
98 \\
1260 \\
475 \\
91 \\
162\end{array}$ & $\begin{array}{r}11 \\
82 \\
360 \\
255 \\
93 \\
152\end{array}$ & $\begin{array}{r}33 \\
7 \\
158 \\
610 \\
24 \\
242\end{array}$ \\
\hline D.I. & & 8.56 & $35 \cdot 19$ & 1.77 & $17 \cdot 45$ & $28 \cdot 54$ & \\
\hline
\end{tabular}




\section{APPEANDIX D}

Statistioal analysis of chemical data

D.1. Discriminant function analysis

D.2. Correlation and variance 


\section{STATISTICAL ANALYSIS OF CHEMTCAL DATA}

\section{D.1. Disoriminant funation analysis}

The multivariate statistical technique of discriminant funotion analysis is ideally suited to the present problem of distinction between two groups of chemical variables. It is useful not only to determine the statistical significance of differences between two populations, but the discriminant function so calculated can be used to assign samples of unknown provenance to one population or another. Without reproducing the complex mathematics involved, the procedure may be paraphrased as follows:

Given: a) a nomally distributed population, U, with $\mathrm{n}_{1}$ samples and $\mathrm{k}$ variables, and with $\mathrm{n}_{1}>\mathrm{k}$; and

b) a normally distributed population $\underline{V}$, with $n_{2}$ samples and $k$ variables, and with $n_{2}>k$;

Calculate:

o) the discriminant functions

$$
D=d_{1} x_{1}+d_{2} x_{2}+\ldots d_{k} x_{k}
$$

for each analysis;

and d) the mean discriminant functions $D_{u}$ and $D_{v}$ for each population $\underline{\Psi}$ and $\underline{V}$;

and d) the "deciding discriminant function" $D_{0}$. Determine:

f) the conflderne with which the two populations $\underline{U}$ and $\underline{V}$ can be separated by carrying out an F-ratio test of the null hypothesis that $D_{u}=D_{v}$. 
Calculate: g) for unassigned samples, the discriminant function, D, by multiplication of each variable $x_{1}, x_{2}, \ldots x_{k}$ by the "characteristic numbers" $d_{1}, d_{2}, \ldots d_{k}{ }^{1}$ and adding these products. If $D>D_{0}$, then the sample belongs in population $\underline{U}$; if $\mathrm{D}<\mathrm{D}_{\mathrm{O}}$, then it belongs in population $\underline{V}$.

Discriminant function analysis was employed in the present study to determine a) the statistical significance of chemical differences between Kartala and La Grille lavas, and b) whether the geomorphological boundary between each volcano (see Chapter 2) accords with the geochemical boundary, and e) test the petrographic affinity of the Badjini lavas, and d) if any partioular variable is suitable alone for distinguishing between the two groups of lavas.

The characteristic numbers and deciding discriminant functions for major elements and trace elements are given in Table D-1.

In order to apply the F-ratio test of signiflcance it is necessary that each population has a normal distribution. However, It was shown that $\mathrm{MgO}$ in particular has a skewed distribution in Kartala lavas. Rather than exclude this important variable or the samples which cause the skew, on normalize them as logarlthms, etc., the variables were separated into two groups consisting of the twelve major elements and five trace elements. Cr and N1 were not used because there was insufficient data for La Grille. Separate discriminant functions were calculated for each group of variables, but the F-ratio test was applied only to the trace elements. 
Table D-1

Characteristic numbers and deciding discriminant functions

$\operatorname{VARIABLE}(x)$

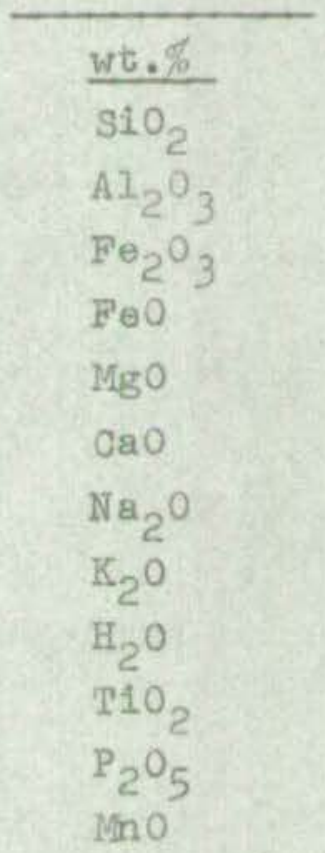

CHARACTERISTIC

NUMBER (a)

$$
\begin{array}{r}
4 \cdot 1497 \\
-4 \cdot 3954 \\
0.4094 \\
-0.6041 \\
-2 \cdot 3352 \\
-2.6257 \\
-9.0274 \\
5.2013 \\
-1 \cdot 8756 \\
5.1049 \\
-3.5413 \\
-17 \cdot 2550
\end{array}
$$

Deciding aiscriminant function $D_{0}=56 \cdot 841$

\begin{tabular}{|cr}
\hline ppm & \\
\hline $\mathrm{Rb}$ & 0.3992 \\
$\mathrm{Cu}$ & -0.0304 \\
$\mathrm{Sr}$ & -0.0292 \\
$\mathrm{Ba}$ & -0.0765 \\
$\mathrm{Zn}$ & -0.1124 \\
$\mathrm{Zr}$ & 0.1773 \\
Deoiding disoriminant function $\mathrm{D}_{0}=-23.0350$ \\
\hline
\end{tabular}


In order to decide which variables are most effective in discriminating between Kartala and La Grille lavas, the correlation coefficlents $(r)$ between each variable and the discriminant function (D) have been calculated. These show (Table $\mathrm{D}-2)$ that $\mathrm{SiO}_{2}, \mathrm{Ba}$, and $\mathrm{P}_{2} \mathrm{O}_{5}$ are effective discriminators at the $99.9 \%$ level and $\mathrm{Sr}$ is suitable at the $99.0 \%$ level of significance. The slgn of $\underline{r}$ indicates whether the variable makes a negative or positive contribution to the discriminant function. Thus, the opposing signs of $\underline{x}$ for $\mathrm{P}_{2} \mathrm{O}_{5}$ in Kartala and La Grille lavas will tend to cancel out its effectiveness as a discriminator.

D.2. Correlation and variance

The matrix of complation coefficients has been calculated for each group of lavas according to the standard equation

$$
x=\frac{n \sum x y-\sum x \sum y}{\left(n \sum x^{2}-\left(\sum x\right)^{2}\right)\left(n \sum y^{2}-\left(\sum y\right)^{2}\right)}
$$

and these are presented in figures $D-1$ and $D-2$.

Some of these cannot be accepted as shown, however, because the variables are not independent, being restricted to the constant sum of $100 \%$. As emphasized by Chayes $(1960,1962)$, the effect of the constant sum is to enhance any negative correlations between variables which make an important contribution to the variance. In order to determine the extent of this effect, the variance for 


\section{Table D-2}

Importance of individual variables $(x)$ in discriminating between Kartala and La Grille lavas, as indicated by their correlations $(x)$ and the discriminant funotions (D)

\begin{tabular}{|c|c|c|c|}
\hline $\operatorname{Varlable}(x)$ & (x) Kartala & (r) Ia G & Gri1 \\
\hline $\mathrm{SiO}_{2}$ & $\cdot 49 * *$ & $\cdot 73$ & $3 * *$ \\
\hline $\mathrm{THO}_{2}$ & $\cdot 33$ & $-\cdot 33$ & \\
\hline $\mathrm{Al}_{2} \mathrm{O}_{3}$ & .09 & -.15 & \\
\hline $\mathrm{Fe}_{2} \mathrm{O}_{3}$ & $\cdot 18$ & -.45 & \\
\hline $\mathrm{F} \otimes \mathrm{O}$ & -.05 & $\cdot 24$ & \\
\hline Mho & .03 & -.24 & \\
\hline $\mathrm{MgO}$ & -20 & $\cdot 16$ & \\
\hline $\mathrm{CaO}$ & -.14 & $-\cdot 34$ & \\
\hline $\mathrm{Na}_{2} \mathrm{O}$ & -.06 & $-\cdot 30$ & \\
\hline $\mathrm{K}_{2} \mathrm{O}$ & -.24 & $-\cdot 36$ & \\
\hline $\mathrm{P}_{2} \mathrm{O}_{5}$ & .19 & $-\cdot 74$ & $+* *$ \\
\hline $\mathrm{H}_{2} \mathrm{O}^{\circ}$ & -.06 & $-\cdot 31$ & \\
\hline $\mathrm{Rb}$ & -.05 & $\cdot 28$ & \\
\hline $\mathrm{Cu}$ & $-\cdot 15$ & $\cdot 43$ & \\
\hline $\mathrm{Sr}$ & .09 & .65 & $5 *$ \\
\hline $\mathrm{Ba}$ & $.38 *$ & .70 & $0 * *$ \\
\hline $\mathrm{Zn}$ & -.05 & -.53 & \\
\hline $\mathrm{Zn}$ & -.07 & $\cdot 28$ & \\
\hline
\end{tabular}

* Significant at the $99.0 \%$ level of confidence. *t. S1gnificant at $99.9 \%$ level of confidence. 
CORAELAT ION MATRIX FOR DATA MATR IX KARTALA I

\begin{tabular}{|c|c|c|c|c|c|c|c|c|}
\hline & $\begin{array}{l}51 \\
\text { NA } \\
2 N\end{array}$ & $\begin{array}{l}n \\
k \\
2 R\end{array}$ & $\begin{array}{l}\text { At. } \\
p_{1}\end{array}$ & $\begin{array}{l}\mathrm{FE}_{2} \mathrm{O}_{3} \\
\mathrm{H}_{2} \mathrm{O}\end{array}$ & $\begin{array}{l}\mathrm{FEg} \\
\mathrm{RB}\end{array}$ & $\begin{array}{l}m n \\
c u\end{array}$ & $\begin{array}{l}46 \\
56\end{array}$ & ${ }_{B A}^{C A}$ \\
\hline st & $\begin{array}{l}1.000000 \\
0.614197 \\
0.058924\end{array}$ & $\begin{array}{l}0.547437 \\
0.559183 \\
0.557553\end{array}$ & $\begin{array}{l}0.670224 \\
0.575586 \\
0.659789\end{array}$ & $\begin{array}{l}-0.031285 \\
-0.293689\end{array}$ & $\begin{array}{r}-0.042229 \\
0.580003\end{array}$ & $\begin{array}{l}-0.135941 \\
-0.145770\end{array}$ & $\begin{array}{r}-c .6670 a c \\
\hdashline . \$ 97154\end{array}$ & $\begin{array}{l}0.29338 \mathrm{c} \\
0.606112\end{array}$ \\
\hline $\mathbf{n}$ & $\begin{array}{l}0.547437 \\
0.920177 \\
0.401315\end{array}$ & $\begin{array}{l}1.000000 \\
0.946328 \\
0.926030\end{array}$ & $\begin{array}{l}0.94<875 \\
0.834938 \\
0.959941\end{array}$ & $\begin{array}{l}0.212180 \\
0.012584\end{array}$ & $\begin{array}{r}-0.017814 \\
0.654413\end{array}$ & $\begin{array}{r}0.070039 \\
-0.211503\end{array}$ & $\begin{array}{r}-r .963101 \\
\text { c.917710 }\end{array}$ & $\begin{array}{l}0 . r 7507 \% \\
\text { e.A1677 }\end{array}$ \\
\hline$A$ & $\begin{array}{l}0.670224 \\
0.928643 \\
0.435240\end{array}$ & $\begin{array}{l}0.940673 \\
0.911057 \\
0.898269\end{array}$ & $\begin{array}{l}1.000000 \\
0.794902 \\
0.957214\end{array}$ & $\begin{array}{r}0.108614 \\
-0.090352\end{array}$ & $\begin{array}{r}-0.008670 \\
0.629392\end{array}$ & $\begin{array}{r}0.037626 \\
-0.166998\end{array}$ & $\begin{array}{r}-1.5 e b 502 \\
\text {. Aa75s4 }\end{array}$ & $\begin{array}{l}0.196629 \\
0.029783\end{array}$ \\
\hline $\mathrm{FE}_{2} \mathrm{O}_{2}$ & $\begin{array}{r}-0.031285 \\
0.085439 \\
-0.039827\end{array}$ & $\begin{array}{l}0.212180 \\
0.203834 \\
0.143095\end{array}$ & $\begin{array}{l}0.168814 \\
0.123201 \\
0.235135\end{array}$ & $\begin{array}{l}1.0000000 \\
0.647226\end{array}$ & $\begin{array}{r}-c .898733 \\
0.176763\end{array}$ & $\begin{array}{r}0.04668 n \\
-0.081504\end{array}$ & $\begin{array}{r}-r .213066 \\
: .253606\end{array}$ & $\begin{array}{l}\text { 6. } 100223 \\
9.108331\end{array}$ \\
\hline FEO & $\begin{array}{r}-0.042229 \\
0.082826 \\
0.251821\end{array}$ & $\begin{array}{l}-0.017814 \\
-0.039439 \\
-0.017641\end{array}$ & $\begin{array}{r}-0.008620 \\
0.006769 \\
-0.065337\end{array}$ & $\begin{array}{l}-0.898783 \\
-0.604819\end{array}$ & $\begin{array}{r}1.000000 \\
-0.117896\end{array}$ & $\begin{array}{l}-0.013283 \\
-0.080008\end{array}$ & $\begin{array}{r}\text { C. } 6836006 \\
-0.103739\end{array}$ & $\begin{array}{l}-0.251518 \\
-0.016015\end{array}$ \\
\hline NW & $\begin{array}{r}-0.135941 \\
-0.099451 \\
0.144243\end{array}$ & $\begin{array}{l}0.070039 \\
0.096219 \\
0.052627\end{array}$ & $\begin{array}{r}0.03762 b \\
-0.049181 \\
-0.005557\end{array}$ & $\begin{array}{l}0.044880 \\
0.084749\end{array}$ & $\begin{array}{l}-0.013283 \\
-0.103963\end{array}$ & $\begin{array}{l}1.000000 \\
0.017627\end{array}$ & $\begin{array}{r}-0.063895 \\
0.015566\end{array}$ & $\begin{array}{l}0.038054 \\
0.002157\end{array}$ \\
\hline NG & $\begin{array}{l}-0.667680 \\
-0.916905 \\
-0.364835\end{array}$ & $\begin{array}{l}-0.943101 \\
-0.915236 \\
-0.883477\end{array}$ & $\begin{array}{l}-0.936502 \\
-0.810346 \\
-0.9451 C 2\end{array}$ & $\begin{array}{r}-0.213066 \\
0.063175\end{array}$ & $\begin{array}{r}0.063606 \\
-0.641433\end{array}$ & $\begin{array}{r}-0.063895 \\
0.119060\end{array}$ & $\begin{array}{r}1.000000 \\
-6.893730\end{array}$ & $\begin{array}{l}=0.302110 \\
-0.823280\end{array}$ \\
\hline CA & $\begin{array}{r}0.293390 \\
0.110757 \\
-0.236525\end{array}$ & $\begin{array}{l}0.075070 \\
0.082815 \\
0.041673\end{array}$ & $\begin{array}{l}0.196629 \\
0.170945 \\
0.024895\end{array}$ & $\begin{array}{r}\text { C. } 100223 \\
-0.128759\end{array}$ & $\begin{array}{r}-0.251518 \\
0.134067\end{array}$ & $\begin{array}{l}0.038054 \\
0.536902\end{array}$ & $\begin{array}{r}-0.302110 \\
0.108324\end{array}$ & $\begin{array}{l}1.0000000 \\
0.177195\end{array}$ \\
\hline NA & $\begin{array}{l}0.616187 \\
1.00000 \\
0.381281\end{array}$ & $\begin{array}{l}0.920177 \\
0.915270 \\
0.899371\end{array}$ & $\begin{array}{r}0.928643 \\
6.801988 \\
0.951109\end{array}$ & $\begin{array}{r}0.085439 \\
-0.200115\end{array}$ & $\begin{array}{l}0.082386 \\
0.025337\end{array}$ & $\begin{array}{l}-0.099451 \\
-0.151771\end{array}$ & $\begin{array}{r}-0.916905 \\
\text { c.871937 }\end{array}$ & $\begin{array}{l}0.110757 \\
0.794619\end{array}$ \\
\hline$\kappa$ & $\begin{array}{l}0.559183 \\
0.915270 \\
0.366501\end{array}$ & $\begin{array}{l}0.946328 \\
1.000000 \\
0.912777\end{array}$ & $\begin{array}{l}0.911057 \\
0.481078 \\
6.955817\end{array}$ & $\begin{array}{l}0.203834 \\
0.012603\end{array}$ & $\begin{array}{r}-0.039439 \\
0.693388\end{array}$ & $\begin{array}{r}0.096219 \\
-0.236940\end{array}$ & $\begin{array}{r}-0.915236 \\
0.952671\end{array}$ & $\begin{array}{l}0.082815 \\
0.861253\end{array}$ \\
\hline p & $\begin{array}{l}0.575560 \\
0.801988 \\
0.183980\end{array}$ & $\begin{array}{l}0.834938 \\
0.881078 \\
0.776306\end{array}$ & $\begin{array}{l}0.784902 \\
1.000000 \\
0.831075\end{array}$ & $\begin{array}{r}0.123201 \\
-0.035000\end{array}$ & $\begin{array}{l}0.000749 \\
0.74177\end{array}$ & $\begin{array}{l}-0.049181 \\
-0.225370\end{array}$ & $\begin{array}{r}-0.810346 \\
0.829768\end{array}$ & $\begin{array}{l}0.170946 \\
0.7\end{array}$ \\
\hline $\mathrm{H}_{2} \mathrm{O}$ & $\begin{array}{l}-0.293689 \\
-0.200115 \\
-0.024965\end{array}$ & $\begin{array}{r}0.012584 \\
\because .012603 \\
-0.054756\end{array}$ & $\begin{array}{l}-0.096352 \\
-0.035009 \\
-0.025951\end{array}$ & $\begin{array}{l}0.647224 \\
1.660000\end{array}$ & $\begin{array}{l}-c .606819 \\
-0.024378\end{array}$ & $\begin{array}{r}0.084749 \\
-0.102364\end{array}$ & $\begin{array}{l}0.003175 \\
0.080717\end{array}$ & $\begin{array}{l}-0.128759 \\
-0.0777259\end{array}$ \\
\hline 28 & $\begin{array}{l}0.580803 \\
0.025397 \\
0.023193\end{array}$ & $\begin{array}{l}0.054413 \\
0.693388 \\
0.535614\end{array}$ & $\begin{array}{l}0.629392 \\
0.741771 \\
0.687862\end{array}$ & $\begin{array}{r}0.176763 \\
-0.024378\end{array}$ & $\begin{array}{r}-1.117896 \\
1.000000\end{array}$ & $\begin{array}{l}-0.103963 \\
-0.144693\end{array}$ & $\begin{array}{r}-0.641433 \\
0.818777\end{array}$ & $\begin{array}{l}0.134967 \\
0.6580-1\end{array}$ \\
\hline CU & $\begin{array}{l}-0.145776 \\
-0.151771 \\
-0.162529\end{array}$ & $\begin{array}{l}-0.211503 \\
=0.236940 \\
=0.130918\end{array}$ & $\begin{array}{l}-0.166998 \\
=0.225370 \\
-0.277766\end{array}$ & $\begin{array}{l}-0.081504 \\
-0.102364\end{array}$ & $\begin{array}{l}=0.080608 \\
=0.144693\end{array}$ & $\begin{array}{l}0.017627 \\
1.000000\end{array}$ & $\begin{array}{r}0.119660 \\
-0.202679\end{array}$ & $\begin{array}{r}0.536902 \\
-0.177036\end{array}$ \\
\hline SR & $\begin{array}{l}0.597154 \\
0.071997 \\
0.250431\end{array}$ & $\begin{array}{l}0.917710 \\
8.952671 \\
0.852003\end{array}$ & $\begin{array}{l}0.987554 \\
0.889768 \\
6.931408\end{array}$ & $\begin{array}{l}0.253604 \\
0.080717\end{array}$ & $\begin{array}{r}-0.103730 \\
0.818777\end{array}$ & $\begin{array}{r}0.0155686 \\
-0.207479\end{array}$ & $\begin{array}{r}-0.893730 \\
1.000000\end{array}$ & $\begin{array}{l}0.108324 \\
0.851857\end{array}$ \\
\hline OA & $\begin{array}{l}0.006112 \\
0.794619 \\
0.207674\end{array}$ & $\begin{array}{l}0.814778 \\
0.801253 \\
\text { C. } 811135\end{array}$ & $\begin{array}{l}c .629783 \\
0.797508 \\
0.823150\end{array}$ & $\begin{array}{r}\text { c. } 1 \text { cos3s } \\
-0.077259\end{array}$ & $\begin{array}{r}-0.016015 \\
0.058041\end{array}$ & $\begin{array}{r}0.062157 \\
-0.177086\end{array}$ & $\begin{array}{r}-0.823280 \\
0.851857\end{array}$ & $\begin{array}{l}0.177195 \\
1.000000\end{array}$ \\
\hline $2 \mathrm{~W}$ & $\begin{array}{l}0.058926 \\
0.381281 \\
1.000000\end{array}$ & $\begin{array}{l}0.401315 \\
0.366501 \\
0.403765\end{array}$ & $\begin{array}{l}0.433240 \\
0.183980 \\
0.401929\end{array}$ & $\begin{array}{l}-0.039827 \\
-0.024965\end{array}$ & $\begin{array}{l}0.251321 \\
0.023193\end{array}$ & $\begin{array}{r}0.144243 \\
-0.102929\end{array}$ & $\begin{array}{r}-0.384835 \\
0.250431\end{array}$ & $\begin{array}{r}-0.236525 \\
0.207676\end{array}$ \\
\hline $2 R$ & $\begin{array}{l}0.557553 \\
0.899371 \\
0.463265\end{array}$ & $\begin{array}{l}0.920030 \\
0.912777 \\
1.000000\end{array}$ & $\begin{array}{l}0.698269 \\
\because 776300 \\
0.924538\end{array}$ & $\begin{array}{r}0.143095 \\
-0.054770\end{array}$ & $\begin{array}{r}-c .017661 \\
0.535014\end{array}$ & $\begin{array}{r}0.052021 \\
-0.130918\end{array}$ & $\begin{array}{r}-c .883477 \\
0.852063\end{array}$ & $\begin{array}{l}0.041673 \\
0.811135\end{array}$ \\
\hline of & $\begin{array}{l}0.659759 \\
0.951109 \\
1.066970\end{array}$ & $\begin{array}{l}0.959041\rangle \\
0.955817 \\
0.924538\end{array}$ & $\begin{array}{l}0.451216 \\
0.831073 \\
1.000010\end{array}$ & $\begin{array}{r}0.735135 \\
-0.025951\end{array}$ & $\begin{array}{r}-0.0651377 \\
0.532782\end{array}$ & $\begin{array}{l}-c . \cos 551 \\
-0.2177 \pi 6\end{array}$ & $\begin{array}{r}-c .045102 \\
\therefore .93140 \text { H }\end{array}$ & $\begin{array}{l}0.024895 \\
0.023150\end{array}$ \\
\hline
\end{tabular}


CORRELATION MATKIX FOR DATA MATRIX GR NIIT I

\begin{tabular}{|c|c|c|c|c|c|c|c|c|}
\hline & $\begin{array}{l}S 1 \\
\text { NA } \\
2 N\end{array}$ & $\begin{array}{l}711 \\
x \\
20\end{array}$ & $\begin{array}{l}\text { At } \\
\text { phi } \\
\text { in }\end{array}$ & $\begin{array}{l}\mathrm{Fl}_{4} \mathrm{OS} \\
\mathrm{H}_{2} \mathrm{O}\end{array}$ & $\begin{array}{l}\mathrm{H} \\
\mathrm{pr}\end{array}$ & $\begin{array}{c}x y \\
c u\end{array}$ & $\begin{array}{l}66 \\
5 n\end{array}$ & $\begin{array}{l}\mathrm{CA} \\
\mathrm{BA}\end{array}$ \\
\hline si & $\begin{array}{l}\text { 1. rcoors } \\
\text { o:i37063 } \\
0.1717657\end{array}$ & $\begin{array}{l}-0.463781 \\
-0.400891 \\
-6.285219\end{array}$ & $\begin{array}{r}\text { C.511073 } \\
-8.040655 \\
2.461620\end{array}$ & $\begin{array}{l}=0.677 \times 41 \\
-6.331523\end{array}$ & $\begin{array}{r}0.537710 \\
-0.65151 .8\end{array}$ & $\begin{array}{l}-0.503374 \\
-9.100619\end{array}$ & $\begin{array}{l}-t .117169 \\
-1: 5 \% \text { mb4 }\end{array}$ & $\begin{array}{l}-0.572806 \\
-0.552916\end{array}$ \\
\hline$n$ & $\begin{array}{r}-0,463781 \\
0.573605 \\
c .091767\end{array}$ & $\begin{array}{l}1 . \text { recroc } \\
0.046337 \\
0.579960\end{array}$ & $\begin{array}{l}0.394642 \\
0.639296 \\
0.364023\end{array}$ & $\begin{array}{l}0.162151 \\
0.248345\end{array}$ & $\begin{array}{r}-6.073632 \\
6.468750\end{array}$ & $\begin{array}{r}0.086553 \\
-9.123393\end{array}$ & 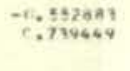 & $\begin{array}{l}0.124609 \\
0.637262\end{array}$ \\
\hline ac & $\begin{array}{l}0.511173 \\
0.006866 \\
0.220611\end{array}$ & $\begin{array}{r}0.099642 \\
-0.063934 \\
0.271071\end{array}$ & $\begin{array}{r}1.060006 \\
-6.152146 \\
0.755646\end{array}$ & $\begin{array}{r}-0.211107 \\
0.051717\end{array}$ & $\begin{array}{l}0.471836 \\
0.087418\end{array}$ & $\begin{array}{l}-0.090645 \\
-0.437697\end{array}$ & $\begin{array}{r}-c .967746 \\
7.167136\end{array}$ & $\begin{array}{l}\text { C. } .184303 \\
0.112008\end{array}$ \\
\hline $\mathrm{FE}_{2} \mathrm{~S}$ & $\begin{array}{r}-0.477091 \\
0.1119692 \\
-0.063563\end{array}$ & $\begin{array}{l}0.162151 \\
0.146662 \\
0.328054\end{array}$ & $\begin{array}{r}-0.211167 \\
\therefore .591894 \\
0.020638\end{array}$ & 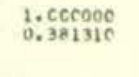 & $\begin{array}{r}-c .092156 \\
0.682818\end{array}$ & $\begin{array}{l}-0.030432 \\
-0.176364\end{array}$ & $\begin{array}{l}c .152540 \\
0.511416\end{array}$ & $\begin{array}{l}0.097993 \\
0.671785\end{array}$ \\
\hline FEO & $\begin{array}{l}0.537710 \\
0.077931 \\
0.268230\end{array}$ & $\begin{array}{l}-0.073652 \\
-0.198572 \\
-0.221321\end{array}$ & $\begin{array}{r}0.471836 \\
-8.472349 \\
0.185586\end{array}$ & $\begin{array}{l}-C .8 \$ 2156 \\
-0.31 \text { a927 }\end{array}$ & $\begin{array}{r}1.000000 \\
-6.602631 \\
\end{array}$ & $\begin{array}{r}0.088339 \\
-0.076072\end{array}$ & $\begin{array}{l}-0.435994 \\
-0.42 \times 897\end{array}$ & $\begin{array}{l}=r .016891 \\
=6.05111\end{array}$ \\
\hline Non & $\begin{array}{r}-0.003374 \\
0.144464 \\
0.403191\end{array}$ & $\begin{array}{l}0.006553 \\
0.24315 \\
0.330822\end{array}$ & $\begin{array}{r}-0.090645 \\
.100516 \\
0.116630\end{array}$ & $\begin{array}{l}=0.030432^{\circ} \\
-0.057390\end{array}$ & $\begin{array}{r}0.088339 \\
-0.033795\end{array}$ & $\begin{array}{l}1.0000000 \\
0.725500\end{array}$ & $\begin{array}{l}0.021431 \\
\because 128323\end{array}$ & $\begin{array}{l}-0.0563122 \\
-0.006317\end{array}$ \\
\hline 16 & $\begin{array}{l}-0.377168 \\
-0.6608097 \\
-0.29773\end{array}$ & $\begin{array}{l}=0.552883 \\
=0.123870 \\
-0.349295\end{array}$ & $\begin{array}{l}-0.967749 \\
-0.013648 \\
-0.761419\end{array}$ & $\begin{array}{r}0.15204 c \\
-0.093829\end{array}$ & $\begin{array}{l}-0.435994 \\
-0.116994\end{array}$ & $\begin{array}{l}0.021481 \\
0.443101\end{array}$ & $\begin{array}{r}1 . \operatorname{con} 000 \\
-i .259575\end{array}$ & $\begin{array}{r}-0.310904 \\
-0.197276\end{array}$ \\
\hline Ca & $\begin{array}{r}-0.572806 \\
0.060459 \\
-0.229949\end{array}$ & $\begin{array}{l}0.724609 \\
0.2997176 \\
0.436569\end{array}$ & $\begin{array}{r}0.166303 \\
0.615560 \\
-0.180836\end{array}$ & $\begin{array}{l}0.097993 \\
0.419275\end{array}$ & $\begin{array}{r}-0.016891 \\
0.246146\end{array}$ & $\begin{array}{l}-0.054307 \\
-0.083912\end{array}$ & $\begin{array}{r}-c .910004 \\
0.525691\end{array}$ & $\begin{array}{l}\text { 1. } 500000 \\
0.519311\end{array}$ \\
\hline va & $\begin{array}{l}0.137063 \\
1.0000000 \\
0.319663\end{array}$ & $\begin{array}{l}0.573605 \\
0.52458 \\
0.466068\end{array}$ & $\begin{array}{l}0.606868 \\
0.225455 \\
0.893890\end{array}$ & $\begin{array}{r}0.119692 \\
-0.320115\end{array}$ & $\begin{array}{l}0.079931 \\
0.329851\end{array}$ & $\begin{array}{r}0.144484 \\
-0.162604\end{array}$ & $\begin{array}{r}-0.66 r 547 \\
6.551772\end{array}$ & $\begin{array}{l}0.060459 \\
9.452505\end{array}$ \\
\hline k & $\begin{array}{r}-0.400891 \\
0.524758 \\
0.126367\end{array}$ & $\begin{array}{l}0.046337 \\
1.00000 \\
0.541388\end{array}$ & $\begin{array}{r}-0.003936 \\
6.652987 \\
0.356188\end{array}$ & $\begin{array}{r}0.146862 \\
-0.290659\end{array}$ & $\begin{array}{r}-0.198572 \\
0.099721 \\
\end{array}$ & $\begin{array}{l}0.243319 \\
0.218618\end{array}$ & $\begin{array}{r}-0.123870 \\
0.535316\end{array}$ & $\begin{array}{l}0.299176 \\
0.424296\end{array}$ \\
\hline p & $\begin{array}{r}-0.830455 \\
0.225455 \\
0.149588\end{array}$ & $\begin{array}{l}0.639290 \\
0.452997 \\
0.544420\end{array}$ & $\begin{array}{l}-0.152146 \\
1.006000 \\
-6.078403\end{array}$ & $\begin{array}{l}0.591854 \\
C .410092\end{array}$ & $\begin{array}{r}-0.472349 \\
0.580044\end{array}$ & $\begin{array}{l}0.108516 \\
0.005485\end{array}$ & $\begin{array}{r}-0.013648 \\
0.740710\end{array}$ & $\begin{array}{l}0.615568 \\
0.6027 \times 7\end{array}$ \\
\hline $\mathrm{H}_{2} \mathrm{O}$ & $\begin{array}{l}-0.331523 \\
-0.320115 \\
-0.035 c 82\end{array}$ & $\begin{array}{r}0.246345 \\
-0.290659 \\
0.042672\end{array}$ & $\begin{array}{r}0.051717 \\
0.416992 \\
-0.269536\end{array}$ & $\begin{array}{l}0.381310 \\
1.0 c 0000\end{array}$ & $\begin{array}{r}-0.318927 \\
0.552916\end{array}$ & $\begin{array}{l}-0.057390 \\
-0.106446\end{array}$ & $\begin{array}{r}-6.093929 \\
0.276175\end{array}$ & $\begin{array}{r}9.419275 \\
0.353524\end{array}$ \\
\hline AB & $\begin{array}{r}-0.451508 \\
0.32951 \\
-0.029041\end{array}$ & $\begin{array}{l}0.443530 \\
0.099721 \\
0.184684\end{array}$ & $\begin{array}{l}0 .(87418 \\
0.586014 \\
0.149121\end{array}$ & $\begin{array}{l}0.68218 \\
0.552916\end{array}$ & $\begin{array}{r}-c .602681 \\
1.000300\end{array}$ & $\begin{array}{l}-0.033795 \\
-0.035204\end{array}$ & $\begin{array}{r}-0.119994 \\
0.113376\end{array}$ & $\begin{array}{l}0.246166 \\
3.705501\end{array}$ \\
\hline cu & $\begin{array}{l}=0.180619 \\
-0.162604 \\
=0.162838\end{array}$ & $\begin{array}{r}-0.123302 \\
0.216618 \\
-0.018373\end{array}$ & $\begin{array}{r}-7.437697 \\
1.005685 \\
-0.269038\end{array}$ & $\begin{array}{l}-0.176364 \\
-9.100466\end{array}$ & $\begin{array}{l}-0.076072 \\
-0.035204 \\
-\end{array}$ & $\begin{array}{l}0.225500 \\
1.000000\end{array}$ & $\begin{array}{l}6.443101 \\
\text { C.237864 }\end{array}$ & $\begin{array}{r}-0.03312 \\
0.114587\end{array}$ \\
\hline sh & $\begin{array}{r}-0.570869 \\
0.551772 \\
-0.077610\end{array}$ & $\begin{array}{l}0.739449 \\
0.535316 \\
0.001366\end{array}$ & $\begin{array}{l}0.147136 \\
0.740710 \\
0.260375\end{array}$ & $\begin{array}{l}0.511416 \\
0.274125\end{array}$ & $\begin{array}{r}-0.423897 \\
0.713376\end{array}$ & $\begin{array}{l}0.128323 \\
0.237964\end{array}$ & $\begin{array}{r}-0.259575 \\
1.000000\end{array}$ & $\begin{array}{l}0.525691 \\
0.929051\end{array}$ \\
\hline 6A & $\begin{array}{r}-0.552916 \\
0.452505 \\
-0.263339\end{array}$ & $\begin{array}{l}0.637262 \\
0.42294 \\
0.566944\end{array}$ & $\begin{array}{l}-1112960 \\
0.02747 \\
i .199266\end{array}$ & $\begin{array}{l}0.671785 \\
0.353524\end{array}$ & $\begin{array}{r}-0.605171 \\
0.700501\end{array}$ & $\begin{array}{r}-0.006377 \\
0.114587\end{array}$ & $\begin{array}{r}-0.197276 \\
0.929051\end{array}$ & $\begin{array}{l}0.519371 \\
1.000000\end{array}$ \\
\hline $2 N$ & $\begin{array}{l}0.177657 \\
0.319643 \\
1.000000\end{array}$ & $\begin{array}{l}0.091767 \\
0.126367 \\
0.031623\end{array}$ & 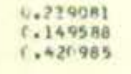 & $\begin{array}{l}-0.063563 \\
-0.035082\end{array}$ & $\begin{array}{r}0.268230 \\
-0.029041\end{array}$ & $\begin{array}{r}0.403191 \\
-3.162630\end{array}$ & $\begin{array}{l}-c .24 m 13 \\
-0 . n 77 \Delta 18\end{array}$ & $\begin{array}{r}-0.229949 \\
-0.263339\end{array}$ \\
\hline 20 & $\begin{array}{r}-0.265210 \\
0.466068 \\
0.031023\end{array}$ & $\begin{array}{l}0.51996 c \\
0.541389 \\
1.0001 t 5\end{array}$ & $\begin{array}{l}1.271671 \\
6.564420 \\
3.336671\end{array}$ & $\begin{array}{l}0.328056 \\
0.042672\end{array}$ & $\begin{array}{r}-0.221321 \\
0.184984\end{array}$ & $\begin{array}{r}0.330022 \\
-0.016373\end{array}$ & $\begin{array}{r}-0.369295 \\
0.601366\end{array}$ & $\begin{array}{l}0.436569 \\
0.568944\end{array}$ \\
\hline D1 & $\begin{array}{l}0.461220 \\
0.893895 \\
0.42 C \$ 95\end{array}$ & $\begin{array}{l}0.364623 \\
6.350180 \\
6.334671\end{array}$ & $\begin{array}{r}\text { C. } 155646 \\
-1.078403 \\
1.000000\end{array}$ & $\begin{array}{r}0.020438 \\
-0.289536\end{array}$ & $\begin{array}{l}0.185586 \\
0.149121\end{array}$ & $\begin{array}{r}0.110639 \\
-c .200030\end{array}$ & $\begin{array}{c}-0.161419 \\
0.269375\end{array}$ & $\begin{array}{r}-0.180086 \\
0.199200\end{array}$ \\
\hline
\end{tabular}


the Kartala and La Grille lavas has been oaloulated (Tables D-3 and $\mathrm{D}-4$, respectively). The six oxides $\mathrm{SiO}_{2}, \mathrm{Al}_{2} \mathrm{O}_{3}, \mathrm{Fe}_{2} \mathrm{O}_{3}$, $\mathrm{FeO}, \mathrm{CaO}$, and $\mathrm{MgO}$ make up $97.9 \%$ and $92.7 \%$ of the total varlance for Kartala and La Grille respectively, and MgO contributes more than all other varlables together in each volcano.

Because of the large vartance given by $\mathrm{MgO}$, any correlations between $\mathrm{MgO}$ and the other five variables will have a strong negative component artifloially imposed by the constant sum effect. This component can be calculated by the equation

$$
E\left(x_{1 j}\right)=\frac{\sigma_{1}}{\sigma_{c}\left(1-M^{\prime}\right)}
$$

where variable 1 is $\mathrm{MgO}$ and variables 1 are $\mathrm{SiO}_{2}, \mathrm{Al}_{2} \mathrm{O}_{3}, \mathrm{Fe}_{2} \mathrm{O}_{3}$, $\mathrm{FeO}$, and $\mathrm{CaO}, \sigma_{c}$ is the mean standard deviation of variables $\mathrm{J}_{\text {, }}$ and $\underline{M^{\prime}}$ is the reduced number of variables (1.e. six) (see Chayes, 1962, p. 4(2). This calculation Indicates that the constant sum effect contributes -0.72 and -0.55 to the Kartala and La Grille correlation coefficlents respectively. For those elements which make insigniflcant contributions to the total variance and are consequently free of constant sum effects, the correlation coefficients can be accepted as given. 
Table D-3

Variance of Kartala chemistry

\begin{tabular}{|c|c|c|c|c|c|}
\hline Variable & Minimum & Mean & Naximum & $\operatorname{Varlance}\left(\sigma^{2}\right)$ & \% Varianco \\
\hline $\mathrm{SIO}_{2}$ & 44.91 & $47 \cdot 16$ & $48 \cdot 76$ & .63 & $2 \cdot 48$ \\
\hline $\mathrm{P}^{\circ} \mathrm{O}_{2}$ & $1 \cdot 49$ & $2 \cdot 38$ & $2 \cdot 79$ & $\cdot 14$ & .55 \\
\hline $\mathrm{Al}_{2} \mathrm{O}_{3}$ & $7 \cdot 78$ & $13 \cdot 41$ & $15 \cdot 70$ & $4 \cdot 29$ & $16 \cdot 88$ \\
\hline $\mathrm{Fe}_{2} \mathrm{O}_{3}$ & .85 & $2 \cdot 80$ & $7 \cdot 52$ & $1 \cdot 14$ & $4 \cdot 48$ \\
\hline FeO & $4 \cdot 51$ & $9 \cdot 06$ & 10.69 & 1.02 & 4.01 \\
\hline Mno & $\cdot 17$ & .19 & $\cdot 47$ & .006 & * \\
\hline $\mathrm{MgO}$ & $5 \cdot 21$ & $8 \cdot 38$ & $21 \cdot 07$ & $17 \cdot 15$ & 67.47 \\
\hline $\mathrm{CaO}$ & 9.07 & $11 \cdot 53$ & $13 \cdot 40$ & .65 & $2 \cdot 56$ \\
\hline $\mathrm{Na}_{2} \mathrm{O}$ & $1 \cdot 42$ & 2.93 & $3 \cdot 54$ & $\cdot 31$ & $1 \cdot 22$ \\
\hline$\pi_{2} \mathrm{O}$ & $\cdot 48$ & 1.19 & 1.63 & .09 & 35 \\
\hline $\mathrm{P}_{2} \mathrm{O}_{5}$ & $\cdot 23$ & $\cdot 40$ & .52 & .006 & $*$ \\
\hline $\mathrm{H}_{2} \mathrm{O}^{-}$ & $\cdot 10$ & $\cdot 41$ & 1.19 & .05 & ** \\
\hline $\mathrm{Rb}$ & 10 & 26 & 38 & 53 & * \\
\hline $\mathrm{Cu}$ & 43 & 89 & 146 & 466 & $*$ \\
\hline $\mathrm{Sr}$ & 245 & 461 & 600 & 7359 & * \\
\hline $\mathrm{Ba}$ & 200 & 399 & 600 & 7135 & * \\
\hline $\mathrm{Zn}$ & 81 & 102 & 127 & 124 & $*$ \\
\hline $\mathrm{Zn}$ & 110 & 200 & 270 & 166 & * \\
\hline
\end{tabular}

* Insignificant

* Omitted. 
Table D-4

Variance of La Grille chemistry

\begin{tabular}{|c|c|c|c|c|c|}
\hline Variable & Minimum & Mean & Maximum & $\begin{array}{c}\text { Variance } \\
\left(\sigma^{2}\right)\end{array}$ & $\begin{array}{c}\text { Varlance } \\
\%\end{array}$ \\
\hline $\mathrm{SLO}_{2}$ & $47 \cdot 47$ & $43 \cdot 16$ & $46 \cdot 59$ & $1 \cdot 56$ & 11.07 \\
\hline $\mathrm{TIO}_{2}$ & 1.67 & $2 \cdot 00$ & $2 \cdot 30$ & .05 & $4 \cdot \cdot 35$ \\
\hline $\mathrm{Al}_{2} \mathrm{O}_{3}$ & $9 \cdot 06$ & $11 \cdot 97$ & $14 \cdot 00$ & $1 \cdot 74$ & $12 \cdot 35$ \\
\hline & 0.55 & $3 \cdot 03$ & $4 \cdot 53$ & .84 & $5 \cdot 96$ \\
\hline $\mathrm{F} \in \mathrm{O}$ & $7 \cdot 28$ & $8 \cdot 72$ & $10 \cdot 86$ & .89 & $6 \cdot 32$ \\
\hline $\mathrm{MnO}$ & .19 & $\cdot 21$ & $\cdot 28$ & .004 & $\neq$ \\
\hline $\mathrm{MgO}$ & $9 \cdot 48$ & $13 \cdot 28$ & 20.01 & $8 \cdot 03$ & $56 \cdot 99$ \\
\hline $\mathrm{CaO}$ & $10 \cdot 85$ & $11 \cdot 98$ & $13 \cdot 53$ & .56 & $3 \cdot 97$ \\
\hline $\mathrm{Na}_{2} \mathrm{O}$ & 1.88 & $2 \cdot 86$ & $4 \cdot 27$ & $\cdot 29$ & 2.06 \\
\hline & $\cdot 44$ & $1 \cdot 13$ & $1 \cdot 74$ & $\cdot 11$ & $\cdot 78$ \\
\hline $\mathrm{P}_{2} \mathrm{O}_{5}$ & $\cdot 29$ & .56 & .84 & .02 & $: 14$ \\
\hline $\mathrm{H}_{2} \mathrm{O}$ & $\cdot 30$ & $\cdot 77$ & $2 \cdot 30$ & .25 & $\Rightarrow$ 浞 \\
\hline $\mathrm{Rb}$ & 13 & 40 & 101 & 469 & $\star$ \\
\hline $\mathrm{Cu}$ & 60 & 77 & 89 & 42 & $\$$ \\
\hline Sr & 331 & 601 & 792 & 11339 & $*$ \\
\hline $\mathrm{Ba}$ & 350 & 703 & 900 & 24193 & $*$ \\
\hline $\mathrm{Zn}$ & 71 & 90 & 112 & 102 & * \\
\hline $\mathrm{Zx}$ & 130 & 186 & 245 & 1218 & * \\
\hline
\end{tabular}

* Insignificant

*** Omitted 


\section{References Cited}

Chayes, F., 1960. On correlation between variables of constant sum. J. geophys. Res. 65, 4185-4193.

Chayes, F., 1962. Numerioal correlation and petrographic variation. J. Geol. 70, 44,0-452. 
APPENDIX E

Electron microprobe data

Table E.1. Augites

Table E.2. Olivines 
Table E.1. Augites

$\mathrm{CaO} \quad \mathrm{MgO} \quad \mathrm{FeO} \quad \mathrm{TiO}_{2} \quad \mathrm{Al}_{2} \mathrm{O}_{3} \mathrm{Na}_{2} \mathrm{O} \underset{\mathrm{Ca}}{\mathrm{Mol}} \underset{\mathrm{Mg}}{\mathrm{Mol}} \underset{\mathrm{Fe}}{\mathrm{Mol}} \%$

GC-1

\begin{tabular}{llllllllll} 
Core & 21.8 & 13.9 & 8.1 & 2.0 & - & - & 46.0 & 41.2 & 12.8 \\
RIm & 21.8 & 14.6 & 7.8 & 1.7 & - & - & 45.4 & 41.8 & 12.8 \\
Core & 22.7 & 17.6 & 4.4 & 0.6 & - & - & 44.4 & 48.9 & 6.7 \\
RIm & 22.0 & 15.0 & 7.8 & 2.6 & - & - & 44.9 & 42.7 & 12.4 \\
G'mass & 22.6 & 12.1 & 7.1 & 2.1 & - & - & 50.0 & 37.6 & 12.5 \\
G'mass & 20.3 & 14.4 & 8.2 & 2.1 & - & - & 46.1 & 41.4 & 12.5 \\
\hline
\end{tabular}

GC-2

\begin{tabular}{|c|c|c|c|c|c|c|c|c|c|}
\hline $\begin{array}{l}\text { Core } \\
\text { Rim }\end{array}$ & $\begin{array}{l}22 \cdot 0 \\
22 \cdot 3\end{array}$ & $\begin{array}{l}16 \cdot 5 \\
17 \cdot 6\end{array}$ & $\begin{array}{l}5 \cdot 4 \\
4 \cdot 6\end{array}$ & $\begin{array}{l}1.0 \\
0.8\end{array}$ & $\begin{array}{l}3 \cdot 5 \\
2.6\end{array}$ & $\begin{array}{l}0.5 \\
0.2\end{array}$ & $\begin{array}{l}44: 9 \\
44 \cdot 4\end{array}$ & $\begin{array}{l}47 \cdot 2 \\
48 \cdot 9\end{array}$ & $\begin{array}{l}7 \cdot 9 \\
6 \cdot 7\end{array}$ \\
\hline $\begin{array}{l}\text { Core } \\
\text { Rirn }\end{array}$ & $\begin{array}{l}22 \cdot 2 \\
21 \cdot 6\end{array}$ & $\begin{array}{l}15 \cdot 2 \\
15 \cdot 5\end{array}$ & $\begin{array}{l}5 \cdot 4 \\
6 \cdot 6\end{array}$ & $\begin{array}{l}1 \cdot 2 \\
2 \cdot 5\end{array}$ & $\begin{array}{l}3 \cdot 9 \\
7 \cdot 1\end{array}$ & $\begin{array}{l}1.5 \\
0.5\end{array}$ & $\begin{array}{l}46 \cdot 5 \\
44 \cdot 8\end{array}$ & $\begin{array}{l}44 \cdot 2 \\
44 \cdot 8\end{array}$ & $\begin{array}{r}9 \cdot 3 \\
10 \cdot 4\end{array}$ \\
\hline $\begin{array}{l}\text { Core } \\
\text { Rim }\end{array}$ & - & $\begin{array}{l}16 \cdot 0 \\
13.9\end{array}$ & $\begin{array}{l}5 \cdot \frac{1}{6} \\
6 \cdot 6\end{array}$ & $\begin{array}{l}1 \cdot 1 \\
1.8\end{array}$ & $\begin{array}{l}3 \cdot 7 \\
5 \cdot 9\end{array}$ & - & - & - & - \\
\hline $\begin{array}{l}\text { G'mass } \\
\text { G'mass }\end{array}$ & $\begin{array}{l}21 \cdot 2 \\
21 \cdot 3\end{array}$ & $\begin{array}{r}7 \cdot 5 \\
13.8\end{array}$ & $\frac{17}{7} \cdot \frac{1}{2}$ & $\begin{array}{l}2 \cdot 0 \\
2 \cdot 6\end{array}$ & $\begin{array}{l}6 \cdot 0 \\
7 \cdot 0\end{array}$ & $\begin{array}{l}1.3 \\
0.7\end{array}$ & $\begin{array}{l}52 \cdot 8 \\
45 \cdot 8\end{array}$ & $\begin{array}{l}26 \cdot 4 \\
42 \cdot 2\end{array}$ & $\begin{array}{l}20 \cdot 6 \\
12 \cdot 0\end{array}$ \\
\hline
\end{tabular}

GC-26

Core

Rim

$21 \cdot 1 \quad 15 \cdot 2 \quad 5 \cdot 6 \quad 1.5$

$21 \cdot 7 \quad 14 \cdot 7 \quad 5 \cdot 4 \quad 1.5$

$-\quad 45 \cdot 2 \quad 45 \cdot 2 \quad 9 \cdot 6$
$-\quad 46.5$

Core

$\begin{array}{llll}20.6 & 16.3 & 5.5 & 1.2\end{array}$

Rim

$\begin{array}{llll}22 \cdot 3 & 15 \cdot 2 & 5 \cdot 2 & 1 \cdot 7\end{array}$

Core

Rim

$19 \cdot 9 \quad 15 \cdot 8$

$\begin{array}{ll}5 \cdot 5 & 2 \cdot 4\end{array}$

$\begin{array}{llll}22.5 & 16.5 & 5 \cdot 4 & 1.2\end{array}$

G'mass

$20 \cdot 1 \quad 13 \cdot 7$

$6 \cdot 7$

$2 \cdot 3$

G'mass

$21 \cdot 0 \quad 75 \cdot 1 \quad 7 \cdot 2$

$1 \cdot 1$

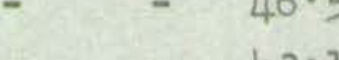

$-\quad 43 \cdot 1$

$144 \cdot 1$

$9 \cdot 5$

$\begin{array}{lll}47 \cdot 7 & 9 \cdot 2\end{array}$

-47.14 .78 .2
-4.7

- $\quad-43.4 \quad 47.09 .6$

$45.0 \quad 46.18 .9$
$-\quad 8.6$

$\begin{array}{llll}-\quad 45.6 & 43.0 & 11.4 \\ -\quad & -\quad 44.2 & 44.2 & 13.5\end{array}$

$G C-30$

$\begin{array}{llllllllll}\text { Core } & 21.8 & 14.0 & 5.8 & 1.6 & - & - & 47.5 & 42.6 & 10.0 \\ \text { Rim } & 19.5 & 13.2 & 7.6 & 2.0 & - & - & 44.4 & 42.1 & 13.5 \\ \text { Dark } & 22.0 & 12.7 & 7.8 & 3.1 & - & - & 48.1 & 38.9 & 13.0 \\ \text { Light } & 21.7 & 13.8 & 7.5 & 2.4 & - & - & 46.4 & 41.2 & 12.4 \\ \text { Light Core } 18.2 & 11.9 & 7.1 & 1.6 & - & - & 45.3 & 41.2 & 14.4 \\ \text { Dark } & 21.2 & 12.0 & 7.4 & 2.7 & - & - & 48.4 & 38.5 & 13.2 \\ \text { Light } & 21.5 & 13.8 & 7.4 & 1.8 & - & - & 46.3 & 41.4 & 12.4 \\ \text { G'mass } & 21.7 & 12.2 & 8.0 & 3.5 & - & - & 48.3 & 38.0 & 13.8\end{array}$


Table E-I (Contd.)

$\mathrm{CaO} \quad \mathrm{MgO} \quad \mathrm{FeO} \quad \mathrm{TIO}_{2} \quad \mathrm{Al}_{2} \mathrm{O}_{3} \mathrm{Na}_{2} \mathrm{O} \quad \mathrm{Cr}_{2} \mathrm{O}_{3} \mathrm{Mol} \% \quad \mathrm{Mol} \% \mathrm{Mol} \%$

GC-31

$\begin{array}{lcccccc}\text { Brown Core } 22.5 & 16.1 & 5.2 & 1.6 & 3.1 & 2.6 \\ \text { Light Core } 22.5 & 16.7 & 4.9 & 0.8 & 3.4 & 0.9 \\ \text { Light Core } & - & 17.3 & 4.5 & 0.9 & - & 1.0 \\ \text { Dark Rim } & - & 15.9 & 6.2 & 1.6 & - & 2.0 \\ \text { Core } & 22.2 & 17.7 & 4.5 & 0.7 & 3.3 & 0.8 \\ \text { Rim } & 21.9 & 16.1 & 6.0 & 1.8 & 4.2 & 1.4 \\ \text { Core } & - & - & - & 1.6 & - & 2.1 \\ \text { Rim } & - & - & - & 1.1 & - & 0.2\end{array}$

$\begin{array}{lllllll}\text { G'mass } & 21.7 & 17 \cdot 1 & 5 \cdot 4 & 1.3 & 3.8 & 1 \cdot 1\end{array}$

G'mass $\quad-\quad 13.55 .4 \quad 1.0 \quad-\quad 0.1$

$45 \cdot 7 \quad 45 \cdot 9 \quad 8 \cdot 4$

$\begin{array}{lll}45 \cdot 4 & 46 \cdot 9 & 7 \cdot 7\end{array}$

$-\quad-\quad-$

$45 \cdot 4 \quad 46 \cdot 9 \quad 7 \cdot 7$

$44 \cdot 5 \quad 46 \cdot 0 \quad 9 \cdot 6$

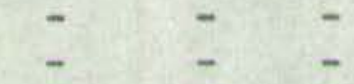

$\begin{array}{llll}43 \cdot 7 & 47 \cdot 0 & 8 \cdot 3\end{array}$

\section{$\mathrm{GC}-35$}

Core

Rim

Core

RIm

G'mass

G'mess

G'mass

G'mass

G'mess

G'mass

GC-41

Core

RIm

Core

Rim

Core

Rim

G'mass

G'mass $\begin{array}{lll}18 \cdot 7 & 16 \cdot 2 & 3 \cdot 8 \\ 19 \cdot 6 & 16 \cdot 4 & -\end{array}$

$20 \cdot 2 \quad 16 \cdot 2$

$21 \cdot 5 \quad 16 \cdot 3$

- 16.5

- $\quad 16 \cdot 3$

-15.9
$-\quad 16.8$

$21 \cdot 0 \quad 16 \cdot 8$

$20 \cdot 5 \quad 16 \cdot 1$

-
-
-
-
-
-
-
-

$4 \cdot 6$

$5 \cdot 3$
$5 \cdot 5$

$5 \cdot 7$

$6 \cdot 4$

$7 \cdot 0$

4.5

$3 \cdot 1$

.


Table E-1 (Contd.)

\begin{tabular}{|c|c|c|c|c|c|c|c|c|c|}
\hline & $\mathrm{CaO}$ & $\mathrm{MgO}$ & $\mathrm{FeO}$ & $\mathrm{PIO}_{2}$ & $\mathrm{Al}_{2} \mathrm{O}_{3}$ & $\mathrm{Na}_{2} \mathrm{O}$ & 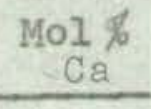 & $\begin{array}{c}\mathrm{Mol} \% \\
\mathrm{Mg}\end{array}$ & $\begin{array}{c}\text { Mol \% } \\
\text { Fe } \\
\end{array}$ \\
\hline \multicolumn{10}{|c|}{ GC- 44} \\
\hline $\begin{array}{l}\text { Core } \\
\text { RIm }\end{array}$ & $\begin{array}{l}19 \cdot 2 \\
19 \cdot 7\end{array}$ & $\begin{array}{l}12.5 \\
11.5\end{array}$ & $\begin{array}{l}11 \cdot 2 \\
11 \cdot 4\end{array}$ & $\begin{array}{l}1 \cdot 6 \\
2 \cdot 4\end{array}$ & $\begin{array}{l}2 \cdot 2 \\
2 \cdot 5\end{array}$ & $\begin{array}{l}1.8 \\
3.5\end{array}$ & $\begin{array}{l}38 \cdot 3 \\
36 \cdot 3\end{array}$ & $\begin{array}{l}42 \cdot 0 \\
43 \cdot 7\end{array}$ & $\begin{array}{l}19 \cdot 7 \\
20 \cdot 0\end{array}$ \\
\hline $\begin{array}{l}\text { Core } \\
\text { Rim }\end{array}$ & - & $\begin{array}{l}12.5 \\
11.1\end{array}$ & $\begin{array}{l}10.7 \\
10.8\end{array}$ & $\frac{1 \cdot 4}{2 \cdot 1}$ & $\overline{-}$ & $\begin{array}{l}2 \cdot 0 \\
2 \cdot 9\end{array}$ & - & - & $\overline{-}$ \\
\hline $\begin{array}{l}\text { Core } \\
\text { RIm }\end{array}$ & $\begin{array}{l}19 \cdot 6 \\
20.5\end{array}$ & $\begin{array}{l}13.0 \\
11.8\end{array}$ & $\begin{array}{l}10 \cdot 6 \\
11 \cdot 1\end{array}$ & $\begin{array}{l}1.5 \\
1.9\end{array}$ & $\begin{array}{l}2 \cdot 0 \\
3 \cdot 5\end{array}$ & $\begin{array}{l}1 \cdot 5 \\
3 \cdot 2\end{array}$ & $\begin{array}{l}39 \cdot 7 \\
36 \cdot 2\end{array}$ & $\begin{array}{l}42 \cdot 2 \\
44 \cdot 5\end{array}$ & $\begin{array}{l}18 \cdot 1 \\
19 \cdot 3\end{array}$ \\
\hline $\begin{array}{l}\text { Core } \\
\text { Rin }\end{array}$ & $\begin{array}{c}21 \cdot 7 \\
-\end{array}$ & $12 \cdot 5$ & $\begin{array}{l}5 \cdot 3 \\
-\end{array}$ & $1: 5$ & $5 \cdot 4$ & $\begin{array}{c}0.6 \\
-\end{array}$ & $\begin{array}{c}40 \cdot 3 \\
-\end{array}$ & $\begin{array}{c}50 \cdot 7 \\
-\end{array}$ & $\begin{array}{c}9 \cdot 0 \\
-\end{array}$ \\
\hline $\begin{array}{l}\text { Core } \\
\text { Rim }\end{array}$ & - & $\begin{array}{l}12 \cdot 8 \\
11 \cdot 0\end{array}$ & $\begin{array}{l}11 \cdot 0 \\
12 \cdot 8\end{array}$ & $\begin{array}{l}1 \cdot 5 \\
2 \cdot 1\end{array}$ & - & $\begin{array}{l}2 \cdot 1 \\
3 \cdot 9\end{array}$ & - & - & - \\
\hline Core & $21 \cdot 3$ & $21 \cdot 3$ & $7 \cdot 4$ & $1 \cdot 4$ & $3 \cdot 6$ & 1.6 & $44 \cdot 2$ & $44 \cdot 2$ & $11 \cdot 6$ \\
\hline
\end{tabular}


Table E-2. Olivine Microprobe Analyses

\begin{tabular}{|c|c|c|c|c|c|c|c|}
\hline & $\begin{array}{c}\text { Total } \\
\text { as } \\
\text { FeO }\end{array}$ & MgO & $\underset{\text { Fol }}{\text { Mol }}$ & & $\begin{array}{c}\text { Total } \\
\text { as } \\
\mathrm{FeO}\end{array}$ & $\mathrm{MgO}$ & $\begin{array}{c}\text { Mol } \% \\
\text { Fo }\end{array}$ \\
\hline $\mathrm{GC}-1$ & & & & $\mathrm{GC}-30$ & atd.) & & \\
\hline $\begin{array}{l}\text { Core } \\
\text { Core } \\
\text { Rim }\end{array}$ & $\begin{array}{l}14 \cdot 2 \\
14 \cdot 9 \\
14 \cdot 2\end{array}$ & $\begin{array}{l}44 \cdot 6 \\
43 \cdot 8 \\
45 \cdot 3\end{array}$ & $\begin{array}{l}84 \cdot 8 \\
83 \cdot 9 \\
85 \cdot 1\end{array}$ & $\begin{array}{l}\text { Micro- } \\
\text { Pheno. } \\
\text { Core } \\
\text { Rim }\end{array}$ & $\begin{array}{l}29 \cdot 1 \\
29 \cdot 1\end{array}$ & $\begin{array}{l}31 \cdot 3 \\
31 \cdot 9\end{array}$ & $\begin{array}{l}66 \cdot 4 \\
66 \cdot 1\end{array}$ \\
\hline $\begin{array}{l}\text { Core } \\
\text { Rim }\end{array}$ & $\begin{array}{l}13 \cdot 2 \\
13 \cdot 2\end{array}$ & $\begin{array}{l}45 \cdot 6 \\
45 \cdot 6\end{array}$ & $\begin{array}{l}86 \cdot 4 \\
86 \cdot 4\end{array}$ & Core & $25 \cdot 1$ & $35 \cdot 8$ & $71 \cdot 5$ \\
\hline $\begin{array}{l}\text { Core } \\
\text { Rim }\end{array}$ & $\begin{array}{l}12 \cdot 7 \\
13 \cdot 2\end{array}$ & $\begin{array}{l}45 \cdot 2 \\
44 \cdot 5\end{array}$ & $\begin{array}{l}86 \cdot 2 \\
86 \cdot 0\end{array}$ & $\begin{array}{l}\text { G'mass } \\
\text { G'mass }\end{array}$ & $\begin{array}{l}28 \cdot 2 \\
25 \cdot 1 \\
\end{array}$ & $\begin{array}{l}33 \cdot 1 \\
33 \cdot 6\end{array}$ & $\begin{array}{l}67 \cdot 9 \\
70 \cdot 6 \\
\end{array}$ \\
\hline $\begin{array}{l}\text { G'mass } \\
\text { G'mass } \\
\text { G'mass }\end{array}$ & $\begin{array}{l}20.5 \\
29.6 \\
28.5\end{array}$ & $\begin{array}{l}37 \cdot 5 \\
30 \cdot 1 \\
31 \cdot 2\end{array}$ & $\begin{array}{l}77 \cdot 0 \\
64 \cdot 5 \\
66 \cdot 2\end{array}$ & $\begin{array}{l}\text { GC-3I } \\
\text { Core } \\
\text { Rim }\end{array}$ & $\begin{array}{l}18 \cdot 2 \\
16 \cdot 3\end{array}$ & $\begin{array}{l}41 \cdot 9 \\
43 \cdot 2\end{array}$ & $\begin{array}{l}80 \cdot 9 \\
82 \cdot 4\end{array}$ \\
\hline$\frac{G C-2}{\text { Core }}$ & $13 \cdot 7$ & $46 \cdot 0$ & 86.0 & $\begin{array}{l}\text { Core } \\
\text { Rim }\end{array}$ & $\begin{array}{l}16 \cdot 1 \\
15 \cdot 7\end{array}$ & $\begin{array}{l}42 \cdot 5 \\
42 \cdot 6\end{array}$ & $\begin{array}{l}82 \cdot 8 \\
82 \cdot 8\end{array}$ \\
\hline $\begin{array}{l}\text { Rim } \\
\text { Gore }\end{array}$ & $\begin{array}{l}15 \cdot 0 \\
14 \cdot 7\end{array}$ & $\begin{array}{l}43 \cdot 7 \\
43 \cdot 7\end{array}$ & $\begin{array}{l}83.7 \\
83.7\end{array}$ & $\begin{array}{l}\text { Core } \\
\text { Rim }\end{array}$ & $\begin{array}{l}17 \cdot 2 \\
17 \cdot 1\end{array}$ & $\begin{array}{l}40 \cdot 6 \\
40 \cdot 7\end{array}$ & $\begin{array}{l}80 \cdot 7 \\
80 \cdot 7\end{array}$ \\
\hline $\begin{array}{l}\text { Rim } \\
\text { Core } \\
\text { Rim }\end{array}$ & $\begin{array}{l}14.7 \\
18.8 \\
20.1\end{array}$ & $\begin{array}{l}44 \cdot 2 \\
40 \cdot 3 \\
38 \cdot 2\end{array}$ & $\begin{array}{l}84 \cdot 6 \\
79 \cdot 6 \\
77 \cdot 3\end{array}$ & $\begin{array}{l}G^{\prime} \operatorname{mass} \\
G^{\prime} m a s s\end{array}$ & $\begin{array}{l}16 \cdot 8 \\
17 \cdot 9 \\
\end{array}$ & $\begin{array}{l}42 \cdot 3 \\
40 \cdot 8 \\
\end{array}$ & $\begin{array}{l}82 \cdot 2 \\
80 \cdot 4 \\
\end{array}$ \\
\hline $\begin{array}{l}\text { G'mass } \\
\text { G'mass } \\
\end{array}$ & $\begin{array}{l}25 \cdot 9 \\
25 \cdot 8 \\
\end{array}$ & $\begin{array}{l}33 \cdot 6 \\
34 \cdot 5 \\
\end{array}$ & $\begin{array}{l}70 \cdot 0 \\
70.5\end{array}$ & $\frac{\mathrm{GC}-35}{\text { Core }}$ & 13.8 & $49 \cdot 6$ & $86 \cdot 7$ \\
\hline $\mathrm{GC}-26$ & & & & $\begin{array}{l}\text {-R1m } \\
\text { Small }\end{array}$ & & & \multirow{4}{*}{$\begin{array}{l}86 \cdot 4 \\
87 \cdot 4 \\
85 \cdot 8 \\
86 \cdot 4 \\
85 \cdot 4 \\
85 \cdot 3\end{array}$} \\
\hline $\begin{array}{l}\text { Core } \\
\text { Rim }\end{array}$ & $\begin{array}{l}19 \cdot 3 \\
19 \cdot 0\end{array}$ & $\begin{array}{l}42 \cdot 9 \\
43 \cdot 9\end{array}$ & $\begin{array}{l}80 \cdot 0 \\
80 \cdot 9\end{array}$ & & 13.5 & $45 \cdot 4$ & \\
\hline G'mass & $20 \cdot 6$ & $40 \cdot 4$ & $77 \cdot 7$ & & & $\begin{array}{l}48.9 \\
45.8\end{array}$ & \\
\hline \multirow{2}{*}{$\frac{\frac{G C-30}{\text { Pheno. }}}{\frac{\text { Core }}{\text { Rim }}}$} & \multirow{2}{*}{$\begin{array}{l}26 \cdot 4 \\
28 \cdot 7\end{array}$} & \multirow{2}{*}{$\begin{array}{l}34 \cdot 2 \\
32 \cdot \frac{4}{4}\end{array}$} & \multirow{2}{*}{$\begin{array}{l}69.8 \\
67.0\end{array}$} & $\begin{array}{r}4 \\
5 \\
6 \\
\end{array}$ & $\begin{array}{l}13.8 \\
13.3 \\
13.5 \\
\end{array}$ & $\begin{array}{l}48 \cdot 4 \\
44 \cdot 8 \\
43 \cdot 7 \\
\end{array}$ & \\
\hline & & & & GC- $4 I$ & & & \\
\hline $\begin{array}{l}\text { Core } \\
\text { Rim }\end{array}$ & $\begin{array}{l}27 \cdot 7 \\
29 \cdot 2\end{array}$ & $\begin{array}{l}32 \cdot 6 \\
32 \cdot 4\end{array}$ & $\begin{array}{l}67 \cdot 2 \\
66 \cdot 2\end{array}$ & $\begin{array}{l}\text { Core } \\
\text { Rim }\end{array}$ & $\begin{array}{l}15 \cdot 0 \\
16 \cdot 7\end{array}$ & $\begin{array}{l}45.0 \\
43.0\end{array}$ & $\begin{array}{l}84 \cdot 5 \\
81 \cdot 5\end{array}$ \\
\hline $\begin{array}{l}\text { Resorbed. } \\
\text { Xeno. }\end{array}$ & & & & $\begin{array}{l}\text { Core } \\
\text { Rim }\end{array}$ & $\begin{array}{l}15 \cdot 6 \\
14 \cdot 5\end{array}$ & $\begin{array}{l}43.7 \\
44.9\end{array}$ & $\begin{array}{l}83 \cdot 3 \\
84 \cdot 9\end{array}$ \\
\hline $\begin{array}{l}\text { Core } \\
\text { Rim }\end{array}$ & $\begin{array}{l}21 \cdot 6 \\
22 \cdot 5\end{array}$ & $\begin{array}{l}37 \cdot 1 \\
34 \cdot 2\end{array}$ & $\begin{array}{l}75 \cdot 5 \\
73 \cdot 5\end{array}$ & $\begin{array}{l}\text { Core } \\
\text { Rim }\end{array}$ & $\begin{array}{l}14 \cdot 7 \\
15 \cdot 4\end{array}$ & $\begin{array}{l}44 \cdot 4 \\
43 \cdot 7\end{array}$ & $\begin{array}{l}84 \cdot 7 \\
84 \cdot 0\end{array}$ \\
\hline
\end{tabular}


Table E-2 (Contd.)

\begin{tabular}{|c|c|c|c|}
\hline & $\mathrm{FeO}$ & $\mathrm{MgO}$ & $\underset{\mathrm{FO}}{\mathrm{Mol}} \%$ \\
\hline \multicolumn{4}{|l|}{$\mathrm{GC}-44$} \\
\hline $\begin{array}{l}\text { Core } \\
\text { Rim }\end{array}$ & $\begin{array}{l}36 \cdot 0 \\
48 \cdot 7\end{array}$ & $\begin{array}{l}25 \cdot 2 \\
16 \cdot 1\end{array}$ & $\begin{array}{l}55.6 \\
37.0\end{array}$ \\
\hline $\begin{array}{l}\text { Core } \\
\text { Rim }\end{array}$ & $\begin{array}{l}43 \cdot 4 \\
57 \cdot 2\end{array}$ & $\begin{array}{l}20 \cdot 0 \\
14 \cdot 9\end{array}$ & $\begin{array}{l}45 \cdot 4 \\
31 \cdot 9\end{array}$ \\
\hline $\begin{array}{l}\text { Core } \\
\text { Rim }\end{array}$ & $\begin{array}{l}34 \cdot 8 \\
27 \cdot 8\end{array}$ & $\begin{array}{l}25 \cdot 8 \\
19 \cdot 3\end{array}$ & $\begin{array}{l}57 \cdot 5 \\
55 \cdot 2\end{array}$ \\
\hline \multirow{2}{*}{$\begin{array}{l}\text { Micro- } \\
\text { pheno. } \\
\text { Micro- } \\
\text { pheno. }\end{array}$} & $45 \cdot 2$ & $18 \cdot 6$ & $42 \cdot 8$ \\
\hline & $37 \cdot 7$ & $23 \cdot 3$ & $52 \cdot 7$ \\
\hline G'mass & $45 \cdot 8$ & $16 \cdot 2$ & $38 \cdot 4$ \\
\hline
\end{tabular}




\section{Plate 1.}

Typical eoastal exposure, southeast Grande Comore.

\section{Plate 2.}

Columar-jointed lavas exposed in walls of Chagnoumeni pit crater. Note interfingering and pinching out of upper flows. The central thick flow $1 \mathrm{~s}$ about 10 metres thiok. 

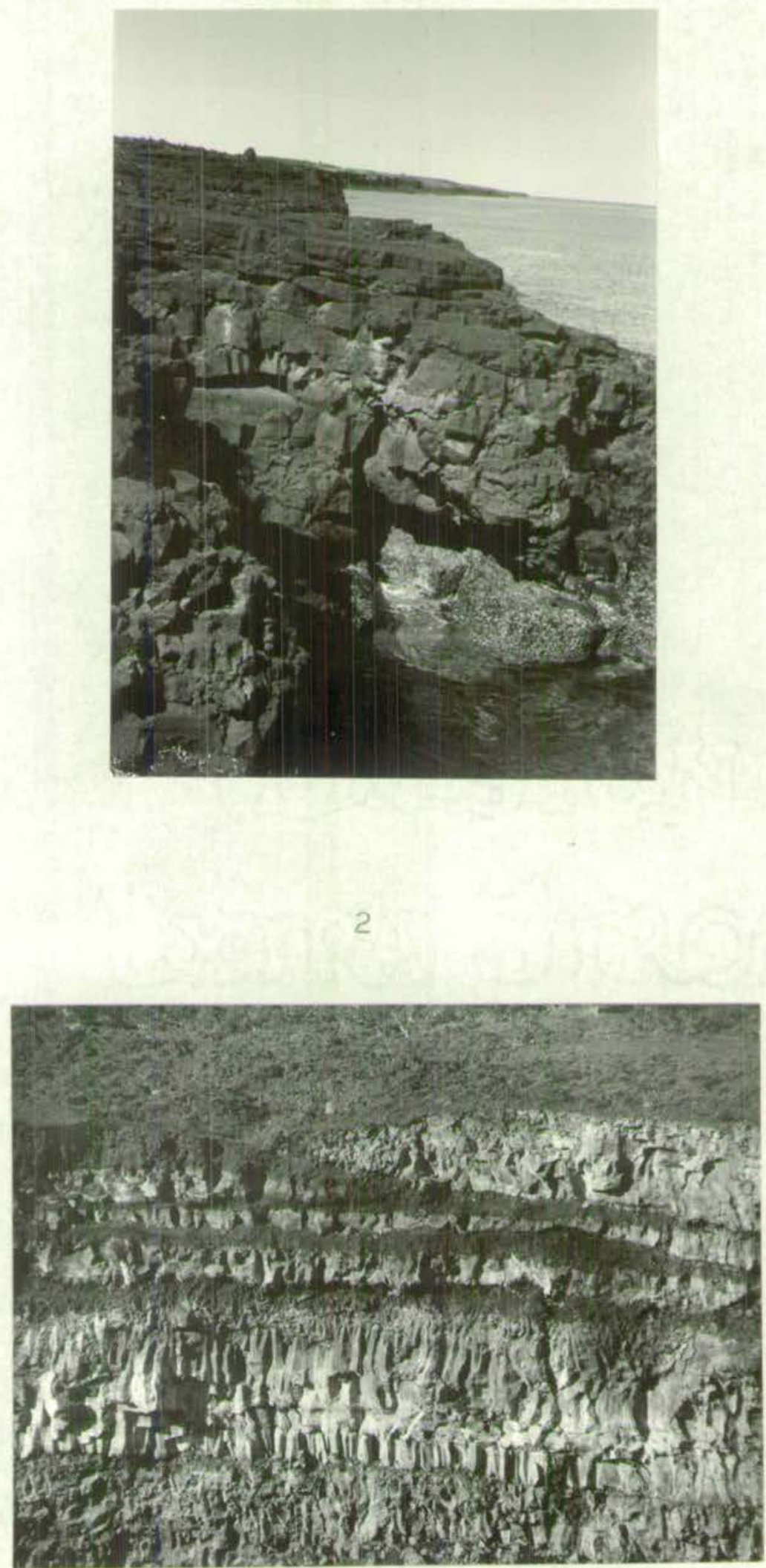
Plate 3.

Plagloclase-phyric flow, Foumboudzivouni. Note baked contacts and flow alignment of plagioclase phenocyrsts in upper flow, and rosette-like clusters in lower ones. 


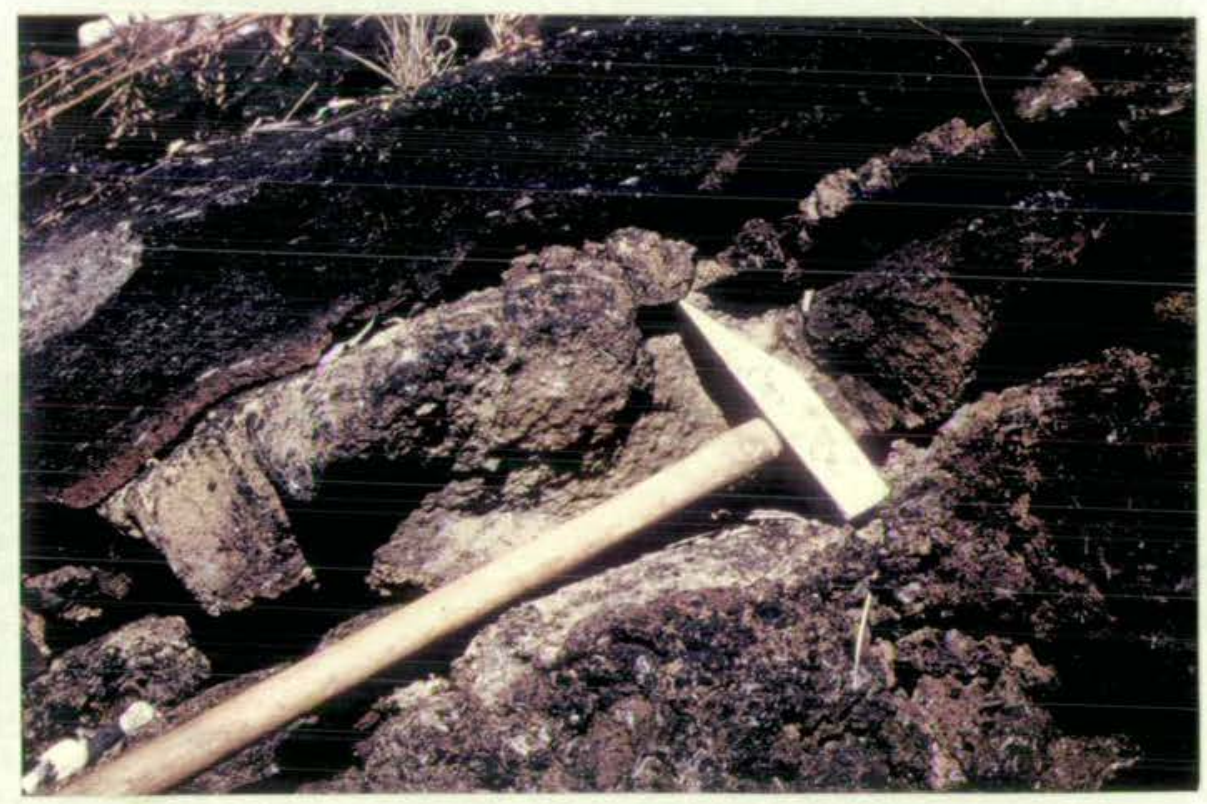




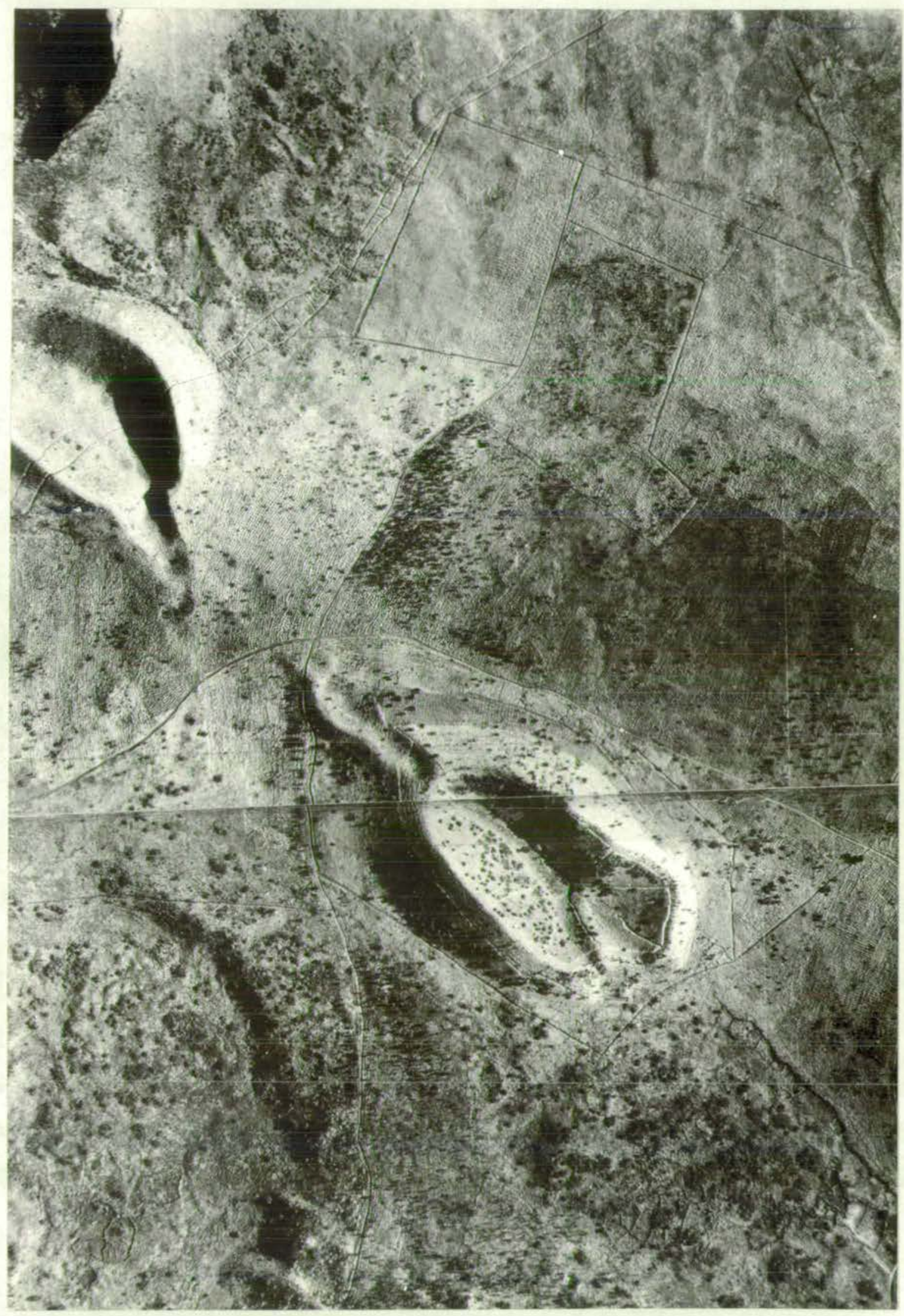




\section{Plate 5.}

Haboho cinder cone, northwest rift zone of Kartala (see Fig. 5). Note soll layers about $50 \mathrm{~cm}$. from top on right side.

\section{Plate 6.}

Sima cinder cone, showing characteristic colours caused by weathering, western Kartala (see Fig. 5). Note ourved sub-horizontal dyke truncating bedding. 


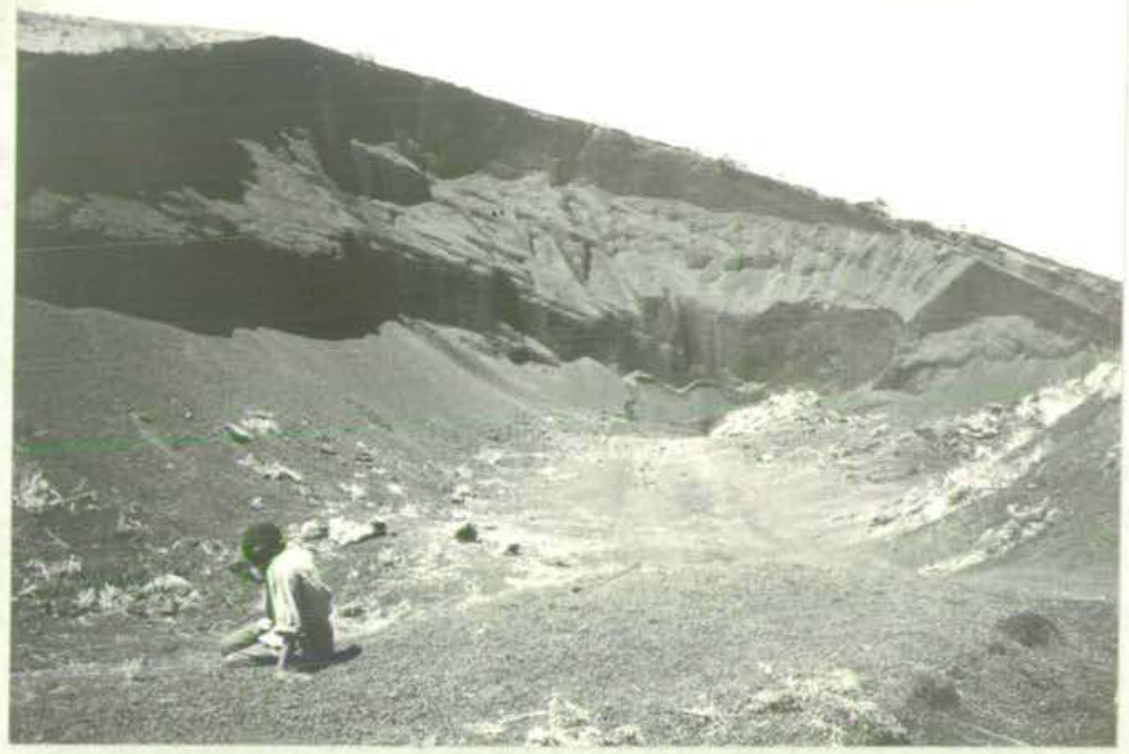

6

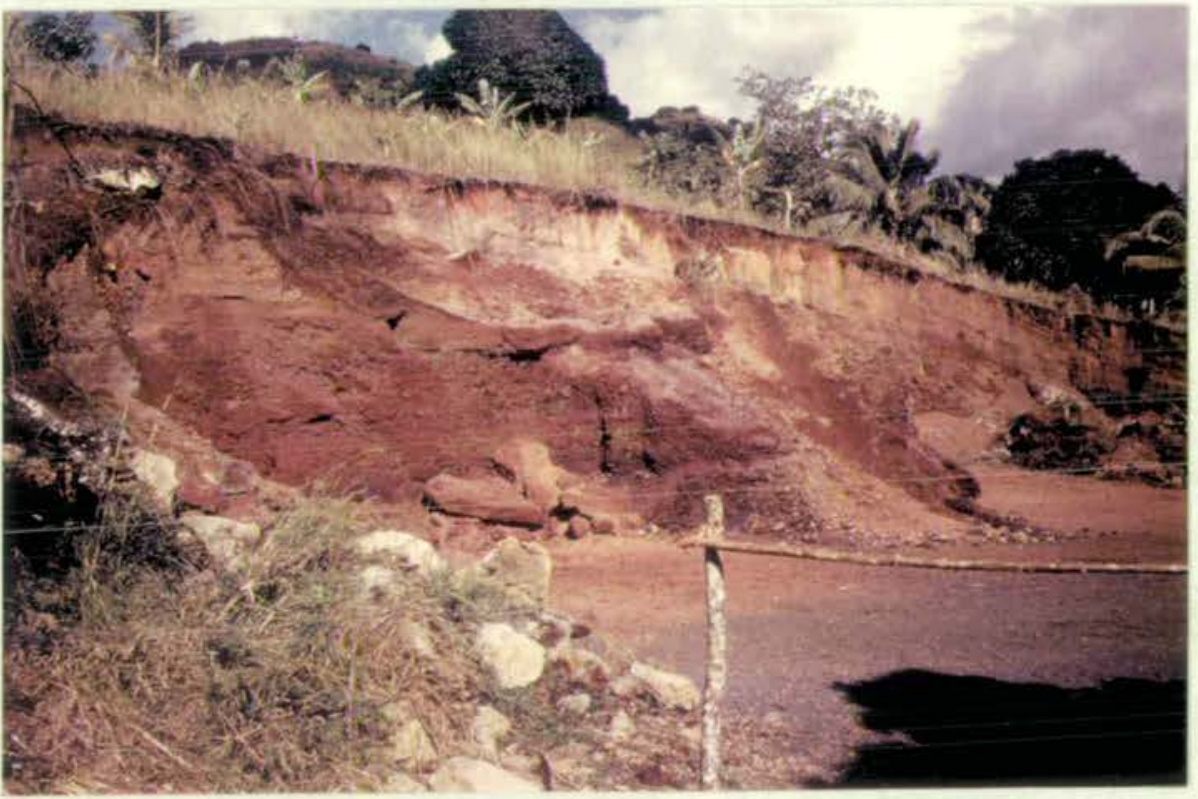




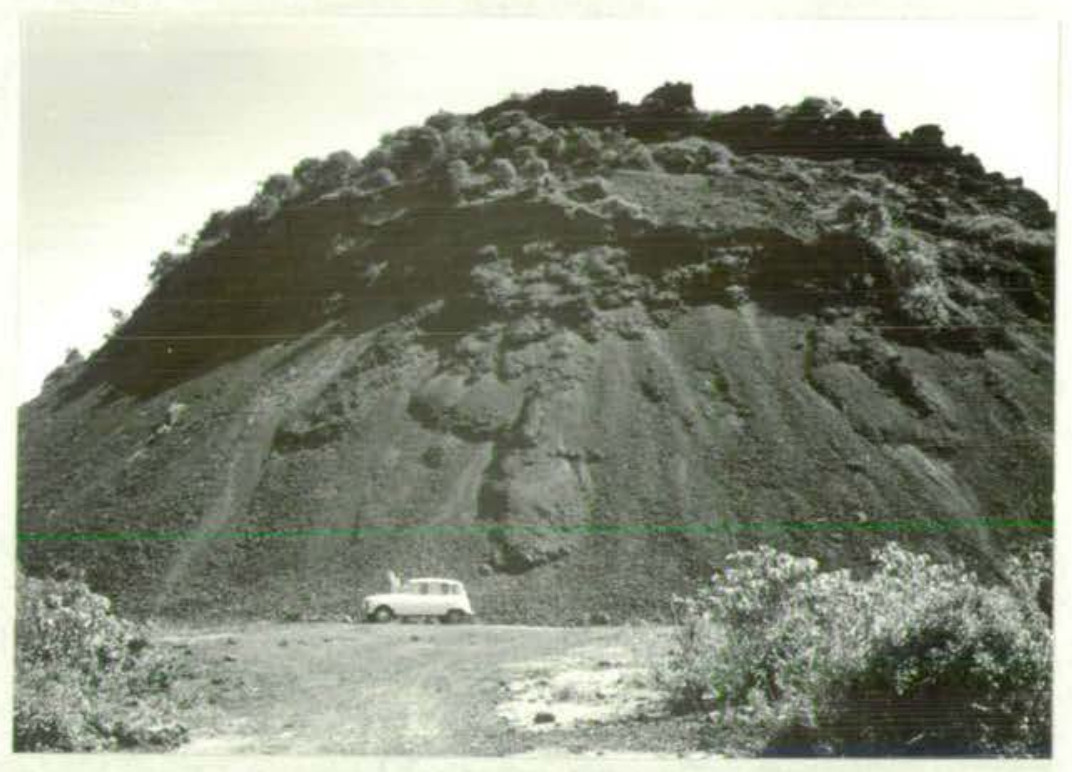

8

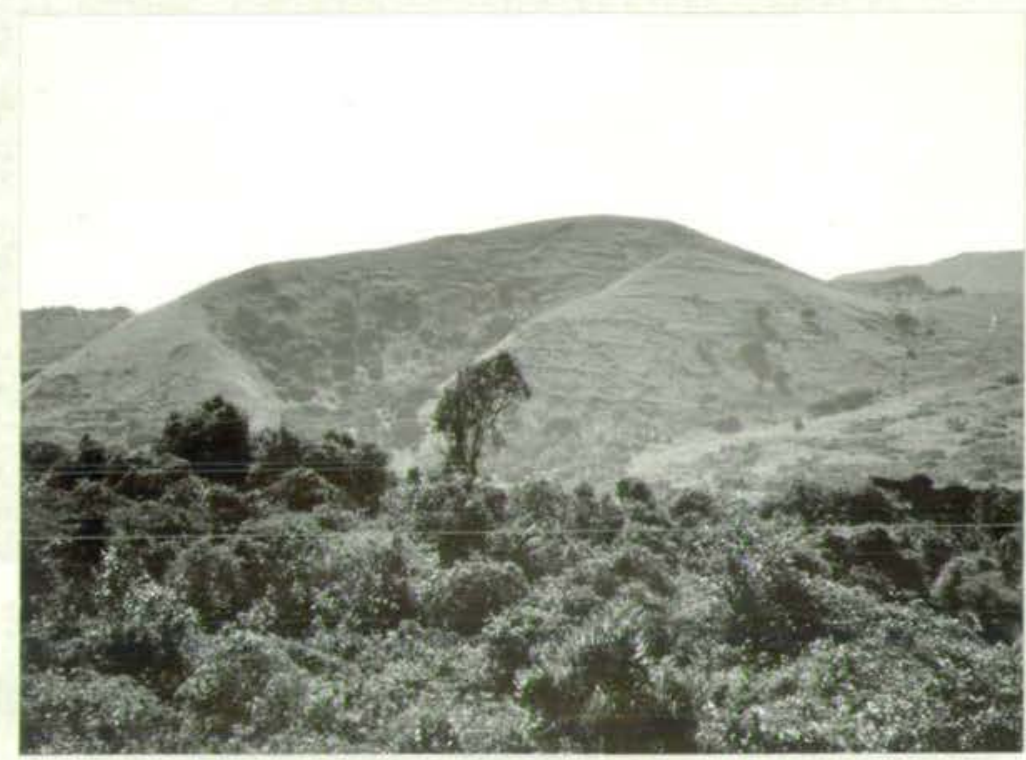




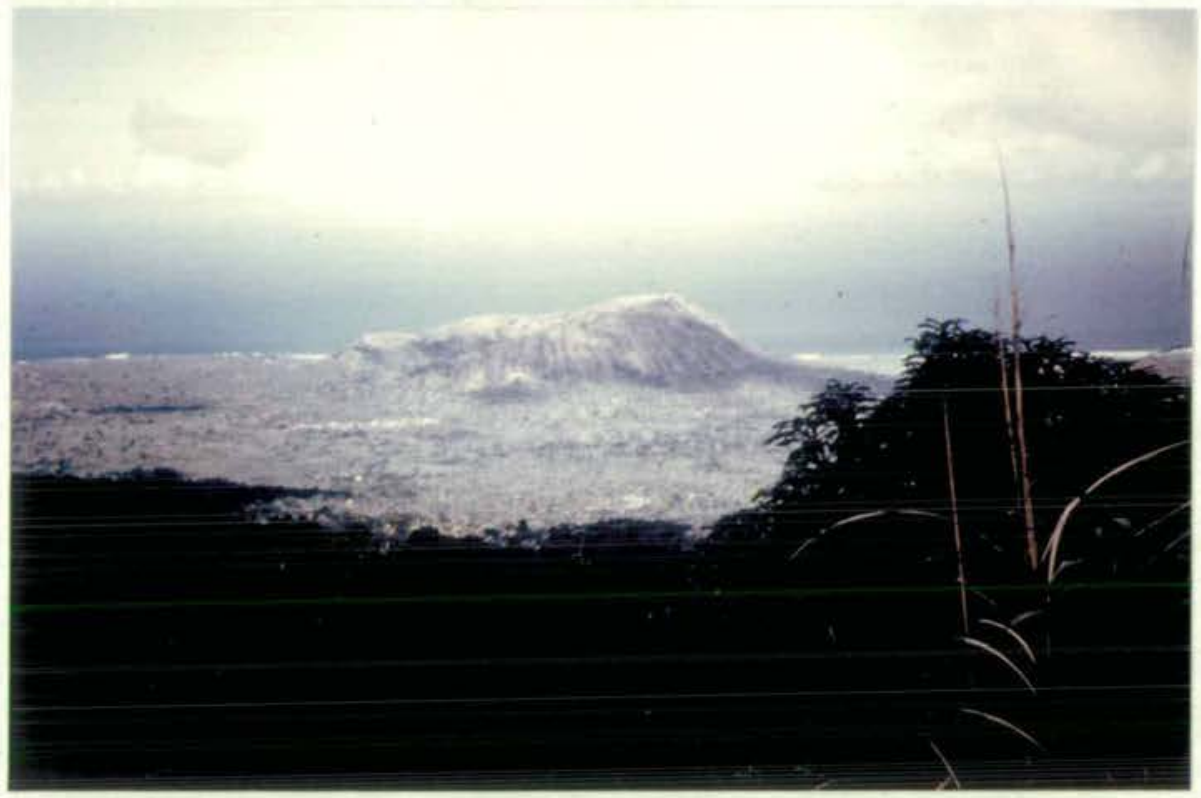

b.

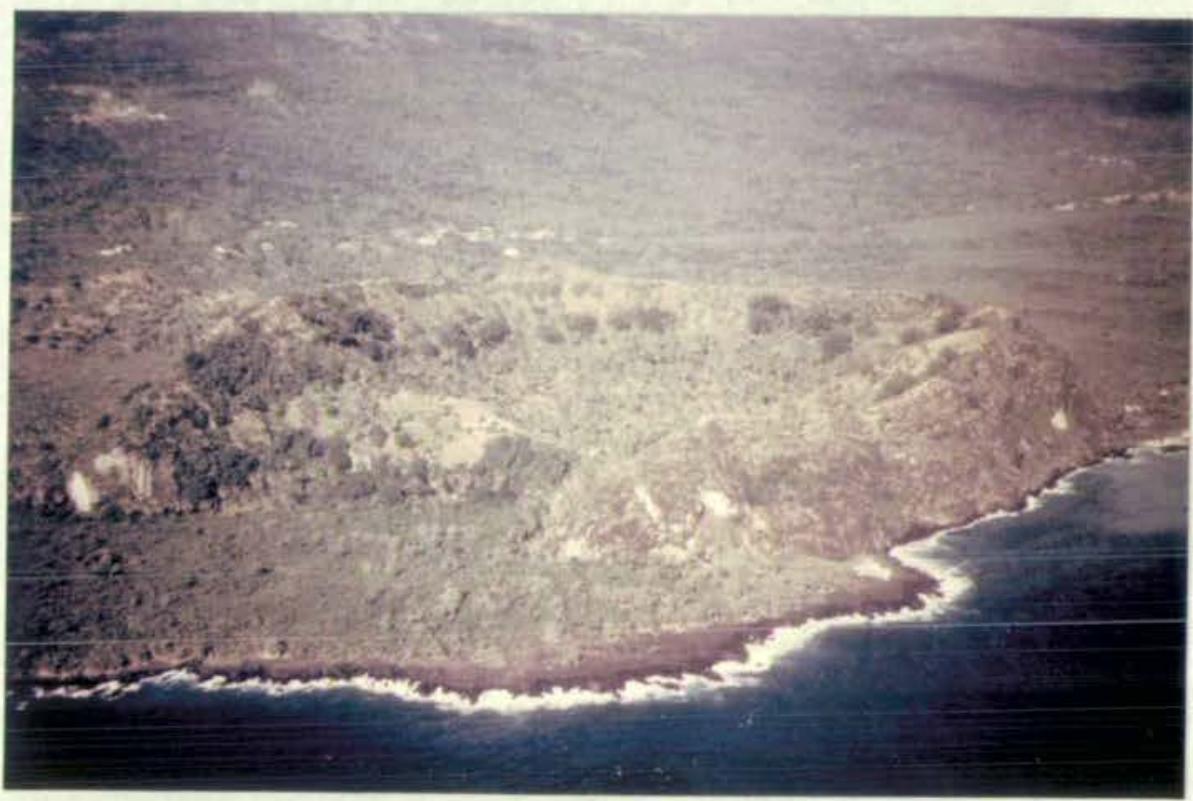




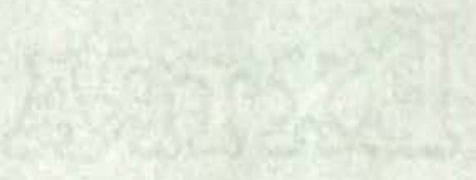

Plate 10.

Panoramic view of the Kartala caldera from its eastern side. The area of overlap of the upper and lower photos can be positioned from the 1965 flow.

Compare with Fig. $7 a$. 


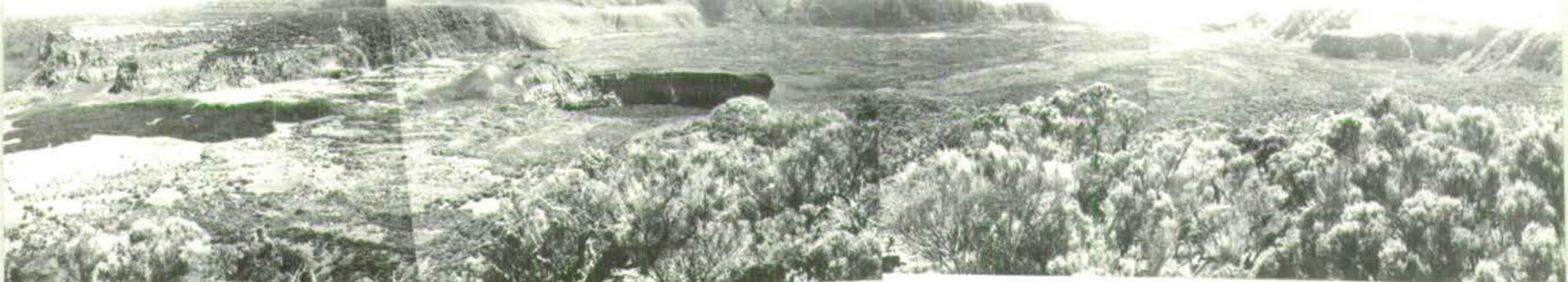

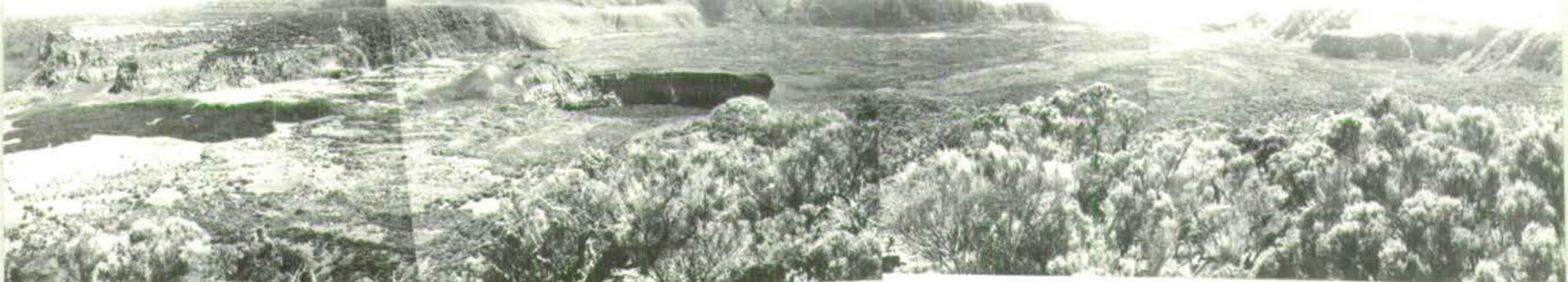

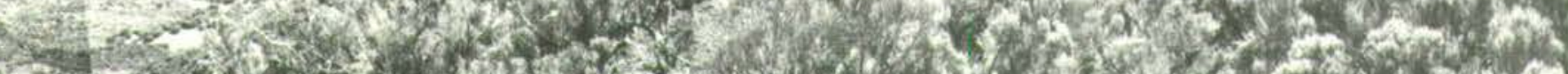

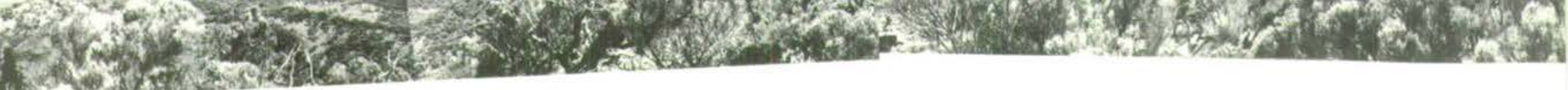

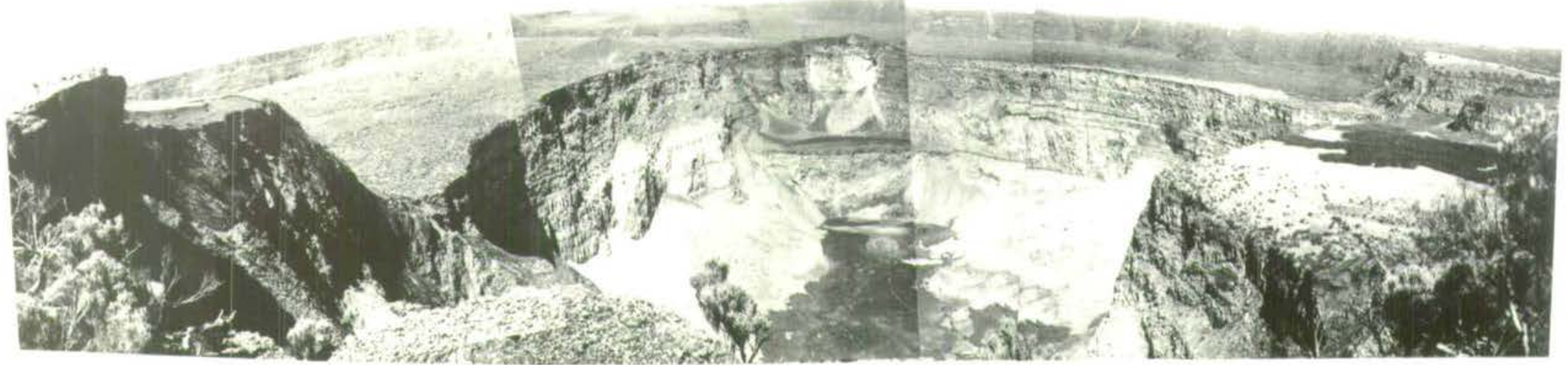




\section{Plate 11.}

Vertical basaltio dyke in wall of Chagnoumeni pit crater. Note characteristic zoning, with vesicular centre, massive outer parts, and glassy margins. Dyke is about 25 om. thick. 


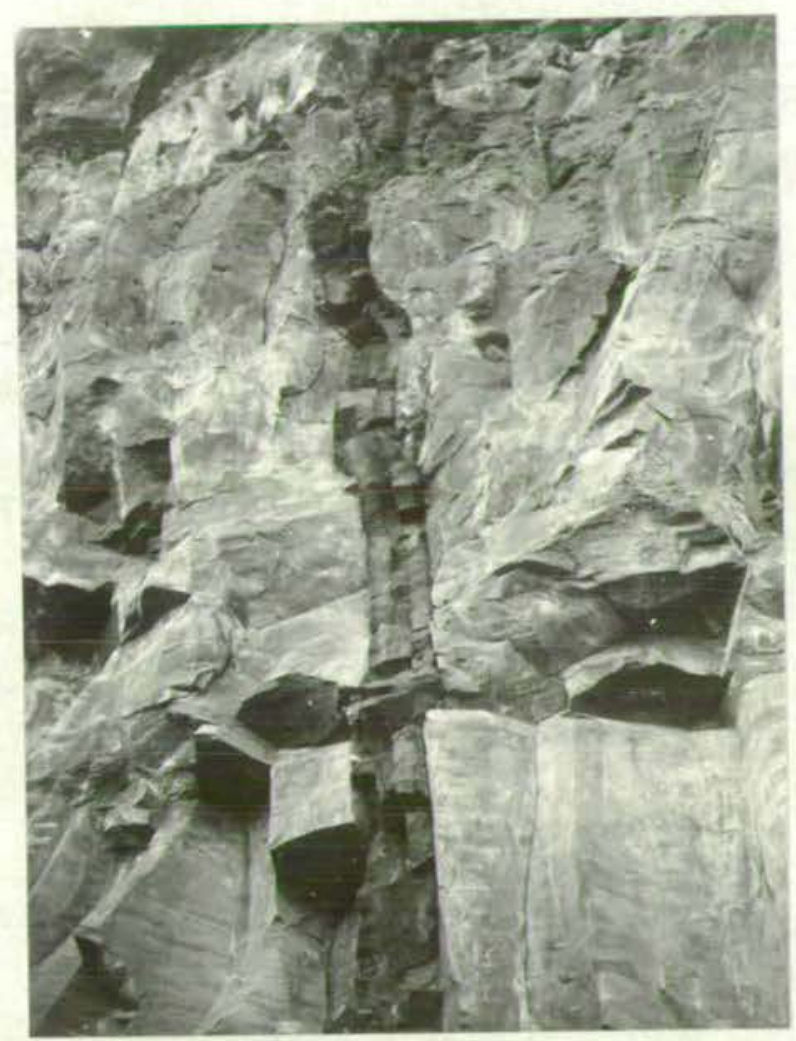


Plate 12.

Alkali basalt (No.32)

Plate 14.

Oceanite (No.18)
Plate 13.

Alkali olivine basalt (No.2)

Ankaramite (No. 31) 
12.

$1 \mathrm{~cm}$.

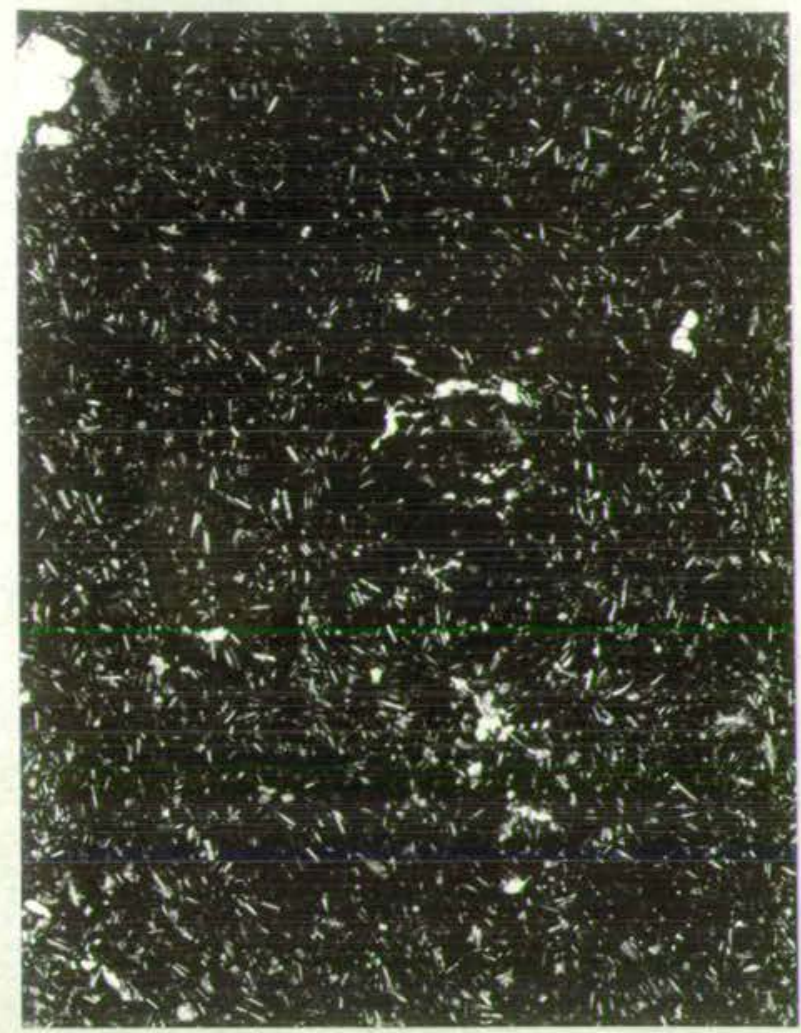

14.

$5 \mathrm{~mm}$.

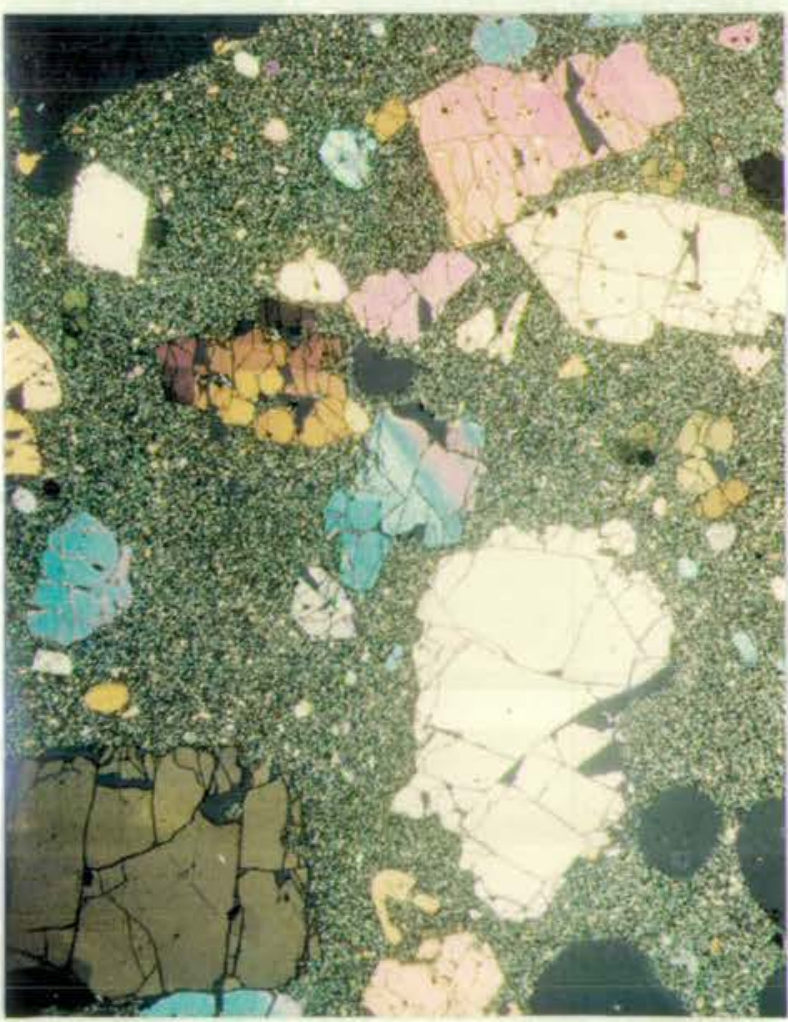

13.

$5 \mathrm{~mm}$.

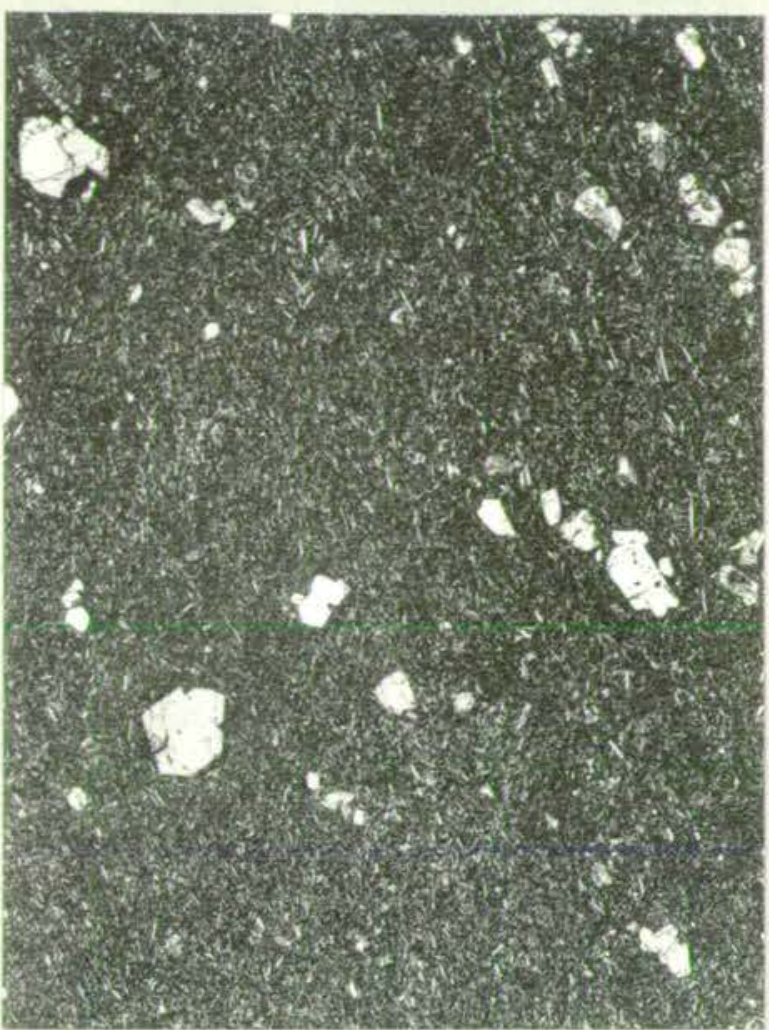

15.

$5 \mathrm{~mm}$.

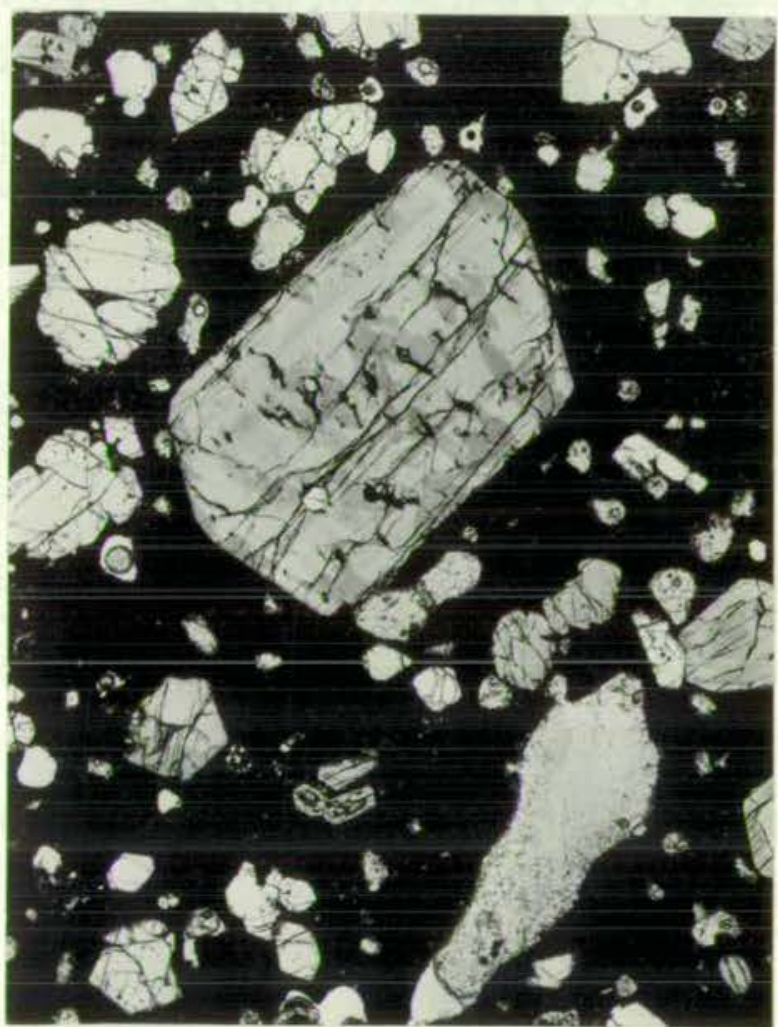




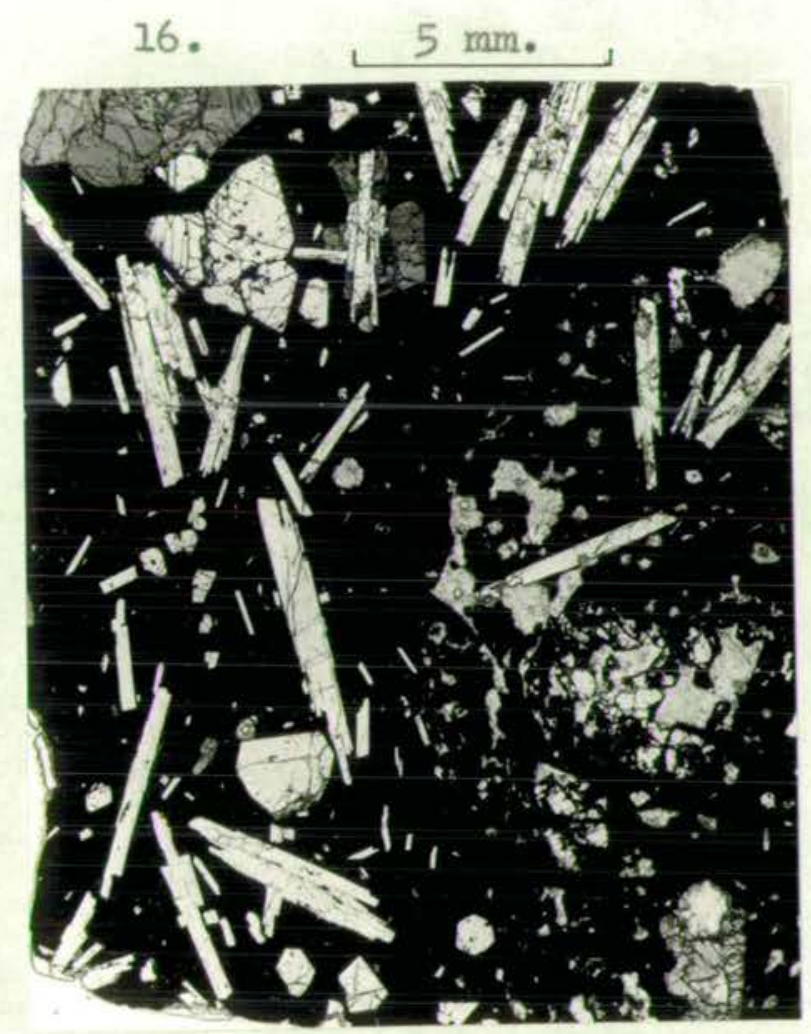

17. $5 \mathrm{~mm}$.

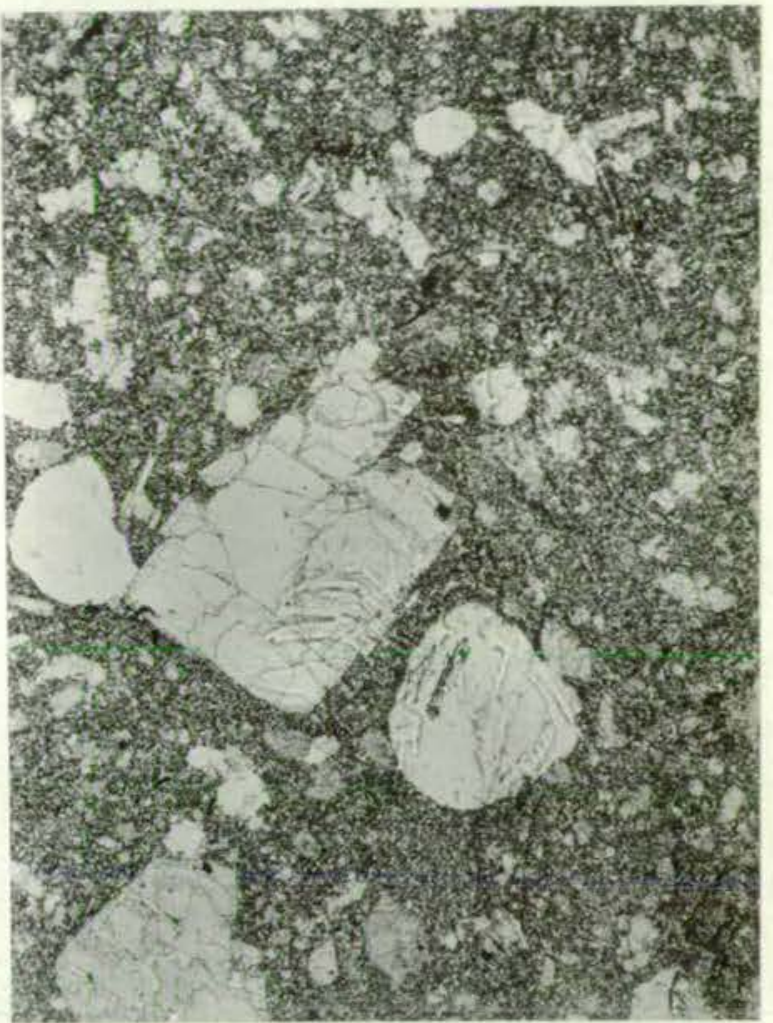

18. $5 \mathrm{~mm}$.

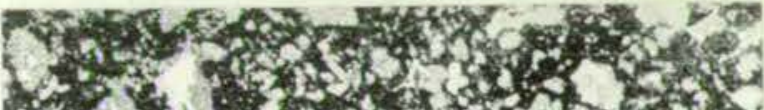

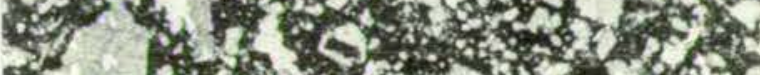

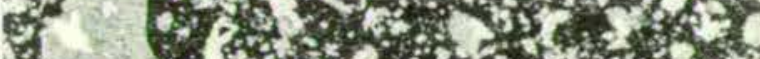

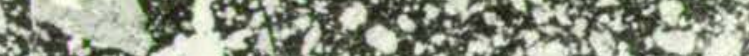

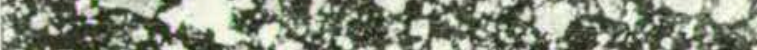

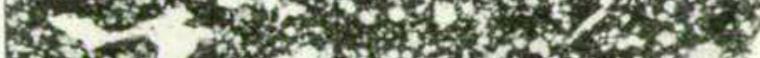

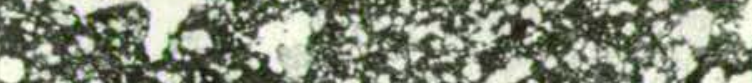

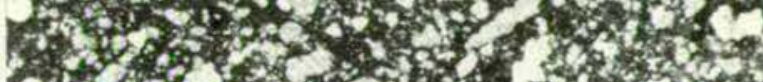

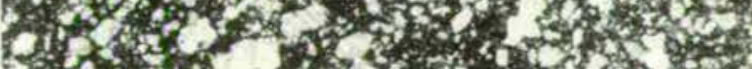
H. of of thollo

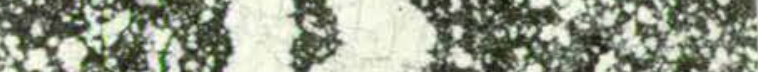

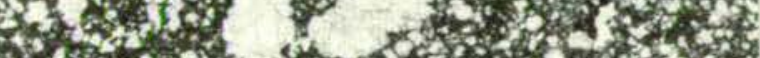

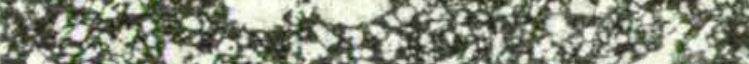
4.

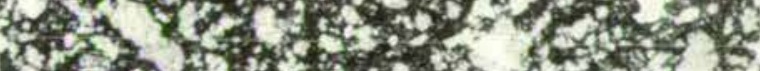

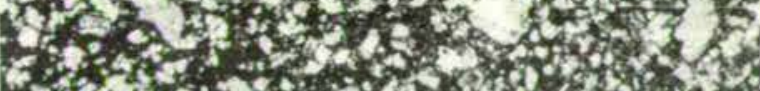

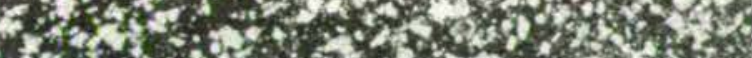

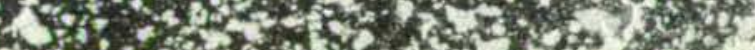

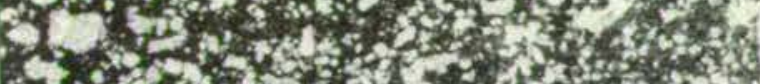

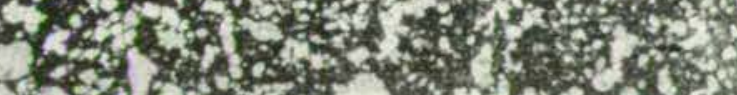




\section{Plate 19.}

Orthopyroxene xenocryst in La Grille lava, surrounded by polysynthetically twinned clinopyroxene. ( $1 \mathrm{~mm}$. di.a.)

\section{Platie 20.}

Quartz xenooryst in La Grille lava, surrounded by elinopyroxene. ( 1 mm. dia.) 


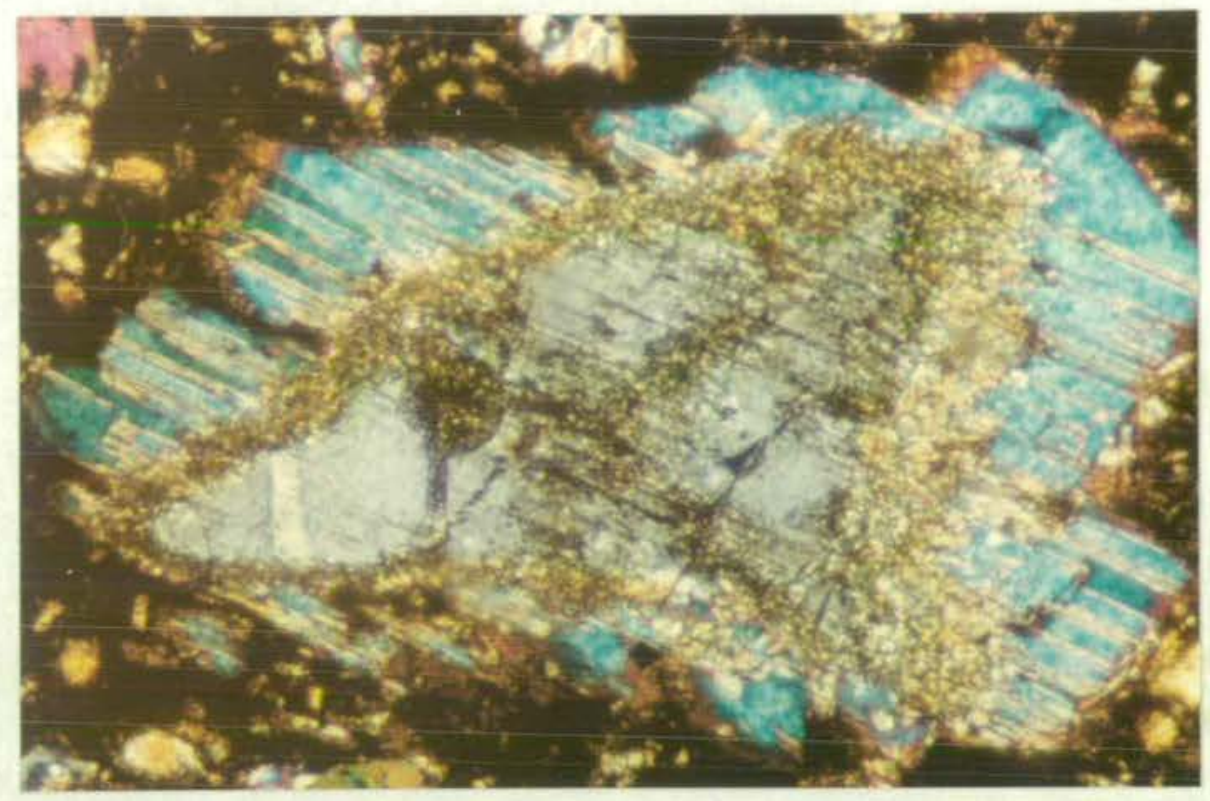

$$
20 .
$$

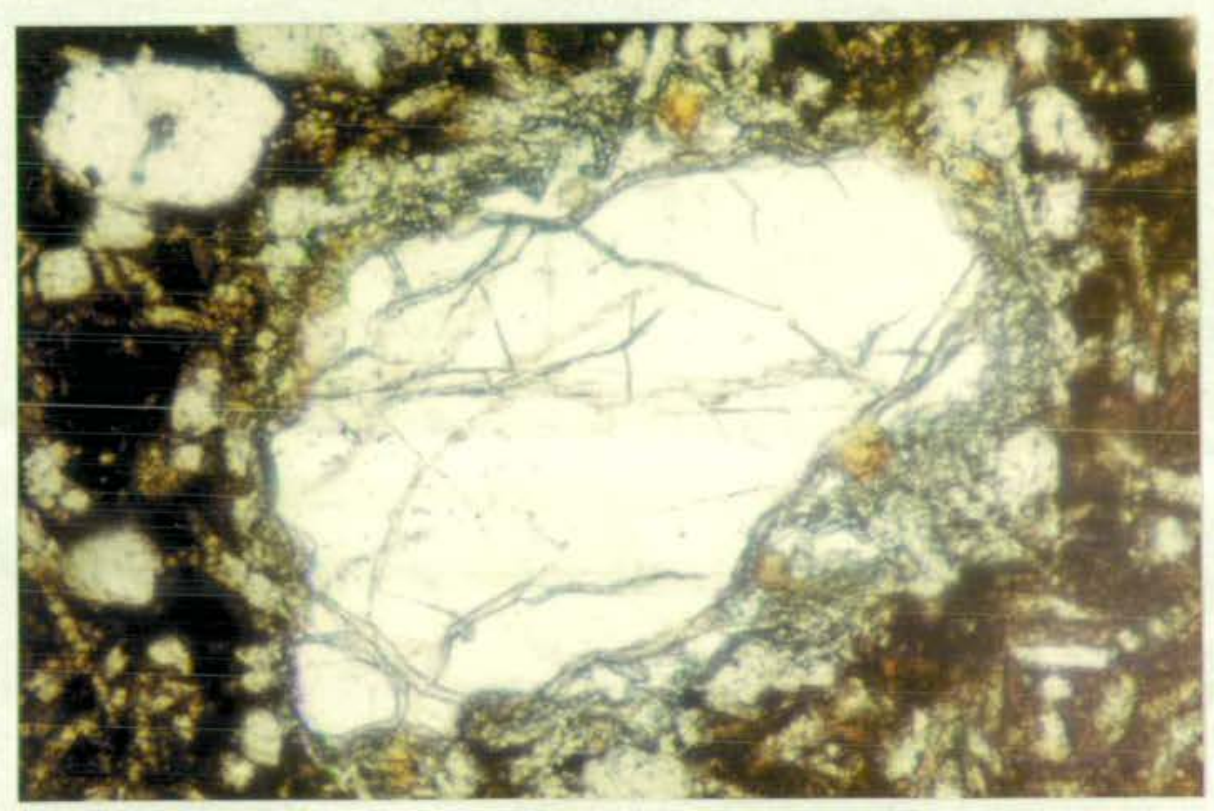

